

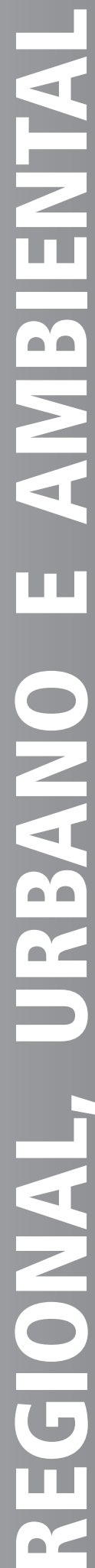

ipea

Rio de Janeiro, 2021

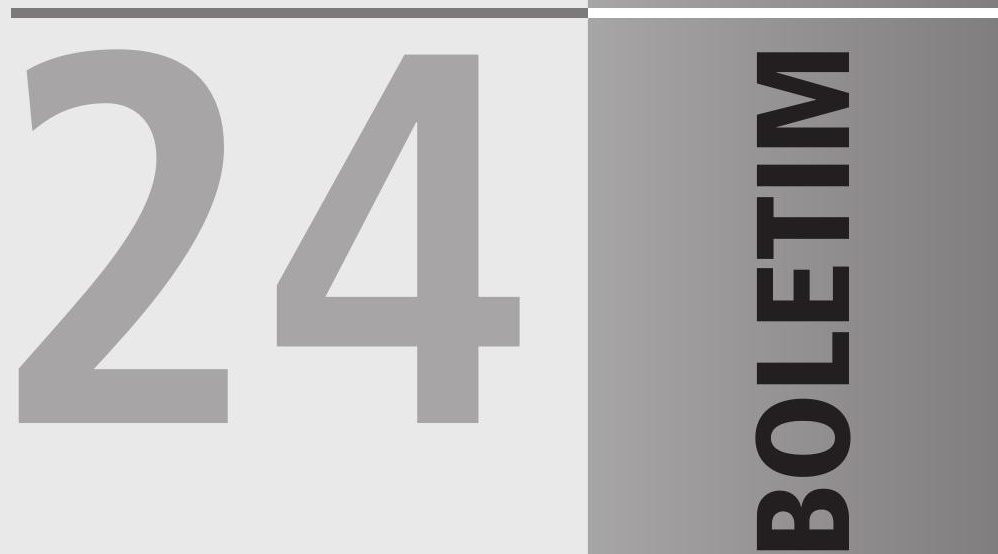


Ministério da Economia

Ministro Paulo Guedes

\section{ipea $=$}

Fundação pública vinculada ao Ministério da Economia, o Ipea fornece suporte técnico e institucional às ações governamentais possibilitando a formulação de inúmeras políticas públicas e programas de desenvolvimento brasileiros - e disponibiliza, para a sociedade, pesquisas e estudos realizados por seus técnicos.

\section{Presidente}

Carlos von Doellinger

Diretor de Desenvolvimento Institucional

Manoel Rodrigues Junior

Diretora de Estudos e Políticas do Estado,

das Instituições e da Democracia

Flávia de Holanda Schmidt

Diretor de Estudos e Políticas Macroeconômicas

José Ronaldo de Castro Souza Júnior

Diretor de Estudos e Políticas Regionais,

Urbanas e Ambientais

Nilo Luiz Saccaro Júnior

Diretor de Estudos e Políticas Setoriais de Inovação

e Infraestrutura

André Tortato Rauen

Diretora de Estudos e Políticas Sociais

Lenita Maria Turchi

Diretor de Estudos e Relações Econômicas

e Políticas Internacionais

Ivan Tiago Machado Oliveira

Assessor-chefe de Imprensa e Comunicação André Reis Diniz

Ouvidoria: http://www.ipea.gov.br/ouvidoria

URL: http://www.ipea.gov.br

\section{Boletim Regional, Urbano e Ambiental}

\section{CORPO EDITORIAL}

\section{Editores}

Mário Jorge Mendonça (coordenador da Coapp)

\section{Conselho Editorial}

Nilo Sacarro (diretor)

Bolívar Pego (coordenador-geral)

Carlos Henrique Ribeiro de Carvalho (Codur)

Júlio César Roma (coordenador da Cosam)

Márcio Bruno Ribeiro (coordenador da Coerf)

Rafael Pereira (coordenador da Dvmeq)

(C) Instituto de Pesquisa Econômica Aplicada - ipea 2021

Boletim regional, urbano e ambiental / Instituto de Pesquisa Econômica Aplicada. Diretoria de Estudos e Políticas Regionais, Urbanas e Ambientais. - n. 1 (dez. 2008) - Brasília : Ipea. Dirur, 2008 -

Semestral.

ISSN 2177-1847

1.Planejamento Regional. 2. Política Regional. 3.Política Urbana. 4. Planejamento Urbano. 5. Urbanismo. 6. Política Ambiental. 7. Brasil. 8. Periódicos. I. Instituto de Pesquisa Econômica Aplicada. Diretoria de Estudos e Políticas Regionais, Urbanas e Ambientais.

CDD 307.7605

DOl: http://dx.doi.org/10.38116/brua24

As publicações do Ipea estão disponíveis para download gratuito nos formatos PDF (todas) e EPUB (livros e periódicos). Acesse: http://www.ipea.gov.br/portal/publicacoes

As opiniões emitidas nesta publicação são de exclusiva e inteira responsabilidade dos autores, não exprimindo, necessariamente, o ponto de vista do Instituto de Pesquisa Econômica Aplicada ou do Ministério da Economia.

É permitida a reprodução deste texto e dos dados nele contidos, desde que citada a fonte. Reproduções para fins comerciais são proibidas. 


\section{SUMÁRIO}

EDITORIAL

ENSAIOS EM ECONOMIA REGIONAL

UMA ANÁLISE EM NÍVEL DE FIRMA DO INVESTIMENTO INDUSTRIAL NO BRASIL

COM ENFOQUE REGIONAL.

Bruno de Oliveira Cruz

UMA ANÁLISE DA DISTRIBUIÇÃO REGIONAL DO FUNDEB EM 2007 E 2017

Kalinca Léia Becker

UM OLHAR TERRITORIAL PARA O MERCADO DE TRABALHO NO BRASIL (2002-2018).....29

Fernando Cézar de Macedo

Leonardo Rodrigues Porto

O FECHAMENTO DAS FRONTEIRAS TERRESTRES AMAZÔNICAS E IMPACTOS

NA MOBILIDADE TRANSNACIONAL

Maria Nunes

UMA CARACTERIZAÇÃO DOS MUNICÍPIOS SEM DECLARAÇÕES DE

RECEITAS ANUAIS NA BASE FINANÇAS DO BRASIL: DADOS CONTÁBEIS

DOS MUNICÍPIOS (2013-2018)

Rodrigo Luis Comini Curi

Luís Gustavo Vieira Martins

Marco Aurélio Costa

A ATUAÇÃO GOVERNAMENTAL EM SÃO GABRIEL DA CACHOEIRA

NO AMAZONAS DURANTE A CRISE DA COVID-19

Rodrigo Portugal

ENSAIOS EM ECONOMIA URBANA

A VIABILIDADE DO IMPOSTO SOBRE O VALOR DA TERRA: ANÁLISE TEÓRICA

E EMPÍRICA, E SEU CONTEXTO NA REFORMA TRIBUTÁRIA.

Claudia M. De Cesare

Cintia Estefania Fernandes

Gelson Santos Oliveira

Pedro Humberto B. Carvalho Junior

A DIMENSÃO TRANSFRONTEIRIÇA NAS LIGAÇÕES INTERNACIONAIS ENTRE

CIDADES: COMENTÁRIOS SOBRE UMA NOVA INFORMAÇÃO DA REGIC 2018.

Rosa Moura

Gustavo Ferreira

Liria Nagamine

PARA FICAR EM CASA É PRECISO TER CASA: A COVID-19 E O DIREITO

À MORADIA NO BRASIL.

Nino Rafael Medeiros Krüger

Caroline Krüger

Gustavo Henrique Soares Ferreira

ENSAIOS EM ECONOMIA AGRÍCOLA E AMBIENTAL

NÚCLEO DE ESTUDOS DE ECONOMIA AGRÍCOLA (NE²AGRO IPEA-MAPA) 113

José Eustáquio Ribeiro Vieira Filho 
EXPORTAÇÕES AGROPECUÁRIAS BRASILEIRAS NOS GRANDES MERCADOS

Rogério Edivaldo Freitas

ASSISTÊNCIA TÉCNICA E EXTENSÃO RURAL NO BRASIL: UMA ANÁLISE

DO CENSO AGROPECUÁRO DE 2017

Caroline Nascimento Pereira

César Nunes de Castro

A COMUNICAÇÃO CORPORATIVA E AS POLITICAS DE COMBATE ÀS

MUDANÇAS CLIMÁTICAS: TEORIAS, PERSPECTIVAS E UMA AVALIAÇÃO DO

USO DAS REDES SOCIAIS NO CASO DO BRASIL

Maria Bernadete Sarmiento Gutierrez

OPINIÃO

APROVEITAMENTO ENERGÉTICO DE RESÍDUOS: UM MERCADO QUE NÃO

SE PODE DESCARTAR

Amaro Olímpio Pereira Junior

NOTAS DE PESQUISA

PANORAMA ATUAL DO BRASIL METROPOLITANO: O ACOMPANHAMENTO

DOS ARRANJOS ESPACIAIS INSTITUCIONALIZADOS DO PROJETO

GOVERNANÇA METROPOLITANA NO BRASIL

Marco Aurélio Costa

Sara Rebello Tavares

IRRIGAÇÃO E DIVERSIFICAÇÃO DA RIQUEZA

Zenaide Rodrigues Ferreira

José Eustáquio Ribeiro Vieira Filho

CONDICIONANTES DA EXPORTAÇÃO BRASILEIRA DA PECUÁRIA DE LEITE

Felipe Pinto da Silva

José Eustáquio Ribeiro Vieira Filho

ESTUDO COMPARADO DE ORGANIZAÇÃO E ADENSAMENTO DE CADEIAS

PRODUTIVAS E SEUS INDICADORES: UMA ANÁLISE DAS CÂMARAS

SETORIAIS ENTRE 1991, 2006 E 2017

Maicon Gonçalves Monteiro

Helinton José Rocha

Marlon Vinícius Brisola

O APOIO À CONSTRUÇÃO DA POLÍTICA NACIONAL DE DESENVOLVIMENTO URBANO...183 Marco Aurélio Costa

Lizandro Lui

CONCESSÕES E PARCERIAS PÚBLICO-PRIVADAS NO DESENVOLVIMENTO URBANO

Jean Marlo Pepino de Paula

INDICADORES

INDICADORES URBANOS E METROPOLITANOS

INDICADOR REGIONAL

INDICADORES AMBIENTAIS. .205

INDICADORES FEDERATIVOS. 


\section{EDITORIAL}

O Boletim Regional, Urbano e Ambiental no 24, da Diretoria de Estudos e Políticas Regionais, Urbanas e Ambientais (Dirur) do Ipea, mantém o mesmo formato de estrutura e conteúdo das ediçôes anteriores, sendo a primeira realizada em 2016. A publicação está dividida em quatro seçôes - Ensaios, Opiniāo, Notas de pesquisa e Indicadores territoriais -, que procuram abranger questôes associadas às áreas regional, federativa, urbana e ambiental. Com essa diversidade temática, pesquisam-se interfaces que orientem uma ação pública mais efetiva, eficaz e eficiente no país. A perspectiva territorial é o elemento central e convergente das avaliaçóes e proposiçôes apresentadas neste boletim. Os ensaios são textos analíticos ou interpretativos que versam sobre determinado assunto, geralmente, mas não necessariamente, de forma menos aprofundada que um tratado formal ou acabado. $\mathrm{O}$ texto de opiniáo aborda temas de destaque para a Dirur/Ipea. As notas de pesquisa são relatos e/ou resultados preliminares de pesquisas em desenvolvimento na Dirur/Ipea. Os indicadores temáticos, por fim, trazem dados macrorregionais/estaduais atualizados periodicamente, com a intenção de construir séries históricas para a realização de análises específicas.

A primeira seção deste boletim é composta por seis ensaios voltados para temas regionais, três sobre desenvolvimento urbano e quatro relacionados à agricultura e ao meio ambiente. No primeiro ensaio, Uma análise em nivel de firma do investimento indústria, Bruno de Oliveira Cruz analisa o comportamento recente do investimento industrial e sua relação com o progresso tecnológico e a adoção de novas tecnologias e busca entender por que existem picos de investimentos e períodos em que as firmas ficam sem investir.

No ensaio seguinte, Kalinca Léia Becker realiza Uma análise da distribuição regional do Fundeb em 2007 e 2017. O Fundo de Manutenção e Desenvolvimento da Educaçáo Básica e de Valorização dos Profissionais da Educação (Fundeb) foi instituído em 2007 com vigência até 31 de dezembro de 2020, para garantir um investimento mínimo por aluno e também promover a distribuição dos recursos em todo o território nacional. Assim, o estudo contribui para a discussão sobre o aprimoramento da lógica de distribuição e alocação dos recursos do fundo, comparando com o produto interno bruto (PIB) per capita dos municípios brasileiros.

O terceiro ensaio lança Um olhar territorial para o mercado de trabalho no Brasil (2002-2018), no qual Fernando Cézar de Macedo e Leonardo Rodrigues Porto analisam a dinâmica regional do mercado formal em dois momentos. O primeiro, de 2002 até 2014, caracterizou-se por crescimento econômico e elevaçáo dos postos de trabalho; e o segundo, entre 2015 e 2018, foi marcado por recessáo e aumento do desemprego. Em Propagação

1. DOI: http://dx.doi.org/10.38116/brua24edit 
geográfica da Covid-19 e o fechamento das fronteiras terrestres amazônicas, Maria Nunes aborda algumas consequências da falta de articulação dos países amazônicos no fechamento de suas fronteiras terrestres e na adoção das medidas de restrição da circulação e da mobilidade transfronteiriça, em função da emergência sanitária mundial instaurada.

No quinto ensaio, Rodrigo Luis Comini Curi, Luís Gustavo Vieira Martins e Marco Aurélio Costa realizam Uma caracterização dos municípios sem declaraçôes de receitas anuais na base Finanças do Brasil - Dados Contábeis dos Municípios (2013 a 2018). A situação socioeconômica desses entes pode ser associada ao perfil e à dinâmica das suas fontes de recursos e à sua capacidade de gasto; logo, quando essas informaçóes se mostram confiáveis, abrangentes e de fácil acesso, podem contribuir para que a elaboração e a implementação de políticas públicas nos municípios brasileiros se tornem mais efetivas.

Fechando os ensaios sobre temas regionais, Rodrigo Portugal analisa $A$ atuação governamental em São Gabriel da Cachoeira no Amazonas durante a crise da Covid-19, uma vez que o município foi um dos principais pontos de proliferação do vírus. A disseminação da doença nesse município ameaça de extinção certas etnias que vivem no seu território, que faz fronteira com a Venezuela e a Colômbia, colocando em risco culturas, línguas e hábitos ancestrais.

Com referência ao desenvolvimento urbano, este boletim apresenta três ensaios. Em A viabilidade do imposto sobre o valor da terra: análise teórica e empírica, e seu contexto na reforma tributária, Claudia M. De Cesare, Cintia Estefânia Fernandes, Gelson Santos Oliveira e Pedro Humberto B. Carvalho Junior analisam a proposta de substituir o Imposto Predial e Territorial Urbano (IPTU) no Brasil por um imposto sobre o valor da terra, considerando aspectos legais, questôes relativas à sua implementação e benefícios potenciais. A seguir, em A dimensão transfronteiriça nas ligaçôes internacionais entre cidades: comentários sobre uma nova informação da Regic 2018, Rosa Moura, Gustavo Ferreira e Liria Nagamine fazem observaçóes acerca da relevância das ligaçóes internacionais na configuração de arranjos transfronteiriços e em sua importância na rede urbana brasileira e também apontam os elementos mais desafiadores na gestão desses espaços. Por fim, para fechar o bloco, temos o ensaio Para ficar em casa é preciso ter casa: a Covid-19 e o direito à moradia no Brasil, de autoria de Nino Rafael Medeiros Krüger, Caroline Krüger e Gustavo Henrique Soares Ferreira. Neste estudo, os autores observam que no momento em que as autoridades sanitárias apontam a necessidade do isolamento físico como estratégia para a contenção do vírus da Covid-19, destacando a importância de hábitos de higiene, grupos que não têm o direito a saneamento e moradia garantido são mantidos em áreas com precária infraestrutura urbana. Assim, o ensaio indica vários instrumentos constantes dentro da legislação que podem ser colocados em ação, de modo que os governos municipais passem a utilizá-los durante o período pandêmico como meio para defender tais grupos.

Os últimos quatro ensaios abordam as atividades agropecuárias e os recursos naturais. José Eustáquio Ribeiro Vieira Filho descreve as ações do Núcleo de Estudos de Economia Agrícola ( $N E^{2} A G R O$ Ipea-Mapa). Trata-se de um grupo de pesquisa vinculado ao Ipea que busca apoiar e subsidiar a tomada de decisão do Ministério da Agricultura, Pecuária e Abastecimento (Mapa) na formulação e na avaliação de políticas públicas relacionadas ao desenvolvimento do setor agropecuário.

$\mathrm{Na}$ sequência, Rogério Edivaldo Freitas analisa as Exportaçôes agropecuárias brasileiras nos grandes mercados, identificando os produtos de maior demanda daqueles mercados junto 
à oferta brasileira no curto prazo recente (2015-2019). Em Assistência técnica e extensão rural no Brasil: uma análise do censo agropecuário de 2017, Caroline Nascimento Pereira e César Nunes de Castro analisam se os produtores agrícolas brasileiros buscam orientação técnica, identificando também a fonte escolhida.

Finalizando a sequência de estudos sobre agricultura, temos o ensaio $A$ comunicação corporativa e as políticas de combate às mudanças climáticas: teorias, perspectivas e uma avaliação do uso das redes sociais no caso do Brasil, no qual Maria Bernadete Sarmiento Gutierrez analisa de que forma as empresas têm utilizado formas diferentes de comunicação a fim de disseminar informações sobre as açóes no combate ao aquecimento global no Brasil.

Na seção Opinião, intitulada Aproveitamento energético de residuos: um mercado que não se pode descartar, Amaro Olímpio Pereira Junior, professor e coordenador do curso de doutorado em planejamento energético do Instituto Alberto Luiz Coimbra de Pós-Graduação e Pesquisa em Engenharia (Coppe), destaca esse promissor mercado para o Brasil, em virtude da disponibilidade de recursos naturais e de resíduos, evidenciando o potencial de geração de emprego e renda por meio de produtos sustentáveis, além dos possíveis ganhos com o comércio internacional.

A seção Notas de pesquisa contém sete relatos. No primeiro, Marco Aurélio Costa e Sara Rebello Tavares investigam O panorama atual do Brasil metropolitano: o acompanhamento dos arranjos espaciais institucionalizados do projeto Governança Metropolitana no Brasil, por meio das informaçóes sistematizadas periodicamente pelo projeto na plataforma Brasil Metropolitano. Zenaide Rodrigues Ferreira e José Eustáquio Vieira Filho apresentam a linha de pesquisa Irrigação e diversificação da riqueza, com o intuito de se aprofundar em temas correlatos da economia agropecuária brasileira, mas fundamentalmente no Semiárido, região que engloba o maior bolsão de pobreza do país. Em Condicionantes da exportação da pecuária de leite brasileira, Felipe Pinto da Silva e José Eustáquio Vieira Filho buscam analisar quais são os principais condicionantes para o mercado internacional de lácteos e em que contexto se insere a economia brasileira.

Em Estudo comparado de organização e adensamento de cadeias produtivas e seus indicadores: uma análise das câmaras setoriais entre 1991 e 2017, Maicon Gonçalves Monteiro, Helinton José Rocha e Marlon Vinícius Brisola compararam os principais indicadores de desempenho das cadeias da cachaça, fibras naturais e de ovinos e caprinos com os indicadores das cadeias do algodão e de aves e suínos com vistas a identificar a eficácia das políticas públicas decorrentes das demandas e estratégias do Ministério da Agricultura, Pecuária e Abastecimento (Mapa) que afetaram o desempenho do setor.

Por fim, os últimos três relatos das Notas de pesquisa tratam do desenvolvimento urbano. Marco Aurélio Costa e Lizandro Lui analisam $O$ apoio à construção de uma política nacional de desenvolvimento urbano, tendo como referência os marcos legais relativos à política, em especial após a Constituição Federal de 1988, abordando também a questão territorial no contexto do federalismo brasileiro e as iniciativas associadas à efetivação do direito à cidade. Por sua vez, Jean Marlo Pepino de Paula faz algumas reflexôes das Concessóes e parcerias público-privadas no desenvolvimento urbano no contexto da formulaçáo da Política Nacional de Desenvolvimento Urbano (PNDU). Em Revendo o valor das infraestruturas urbanas, Jean Marlo Pepino de Paula evidencia a necessidade de rever, resgatar ou redefinir a forma de apropriação das infraestruturas e aparelhos urbanos básicos para o desenvolvimento humano. 
A última seção do boletim, Indicadores territoriais, traz séries de dados atualizados, regionais, federativos, urbanos e metropolitanos, e ambiental, permitindo acompanhar as principais variáveis para análise de diversos temas. Assim, somos gratos aos coordenadores Júlio César Roma, Marco Aurélio Costa e Márcio Bruno Ribeiro, que, com suas respectivas equipes, contribuíram para essa seção.

Prestamos nossos agradecimentos também aos colegas do Ipea que atuaram voluntariamente como pareceristas dos ensaios desta edição.

Que tenham todos e todas uma boa leitura!

O Editor 


\section{ENSAIOS EM ECONOMIA REGIONAL}





\title{
UMA ANÁLISE EM NÍVEL DE FIRMA DO INVESTIMENTO INDUSTRIAL NO BRASIL COM ENFOQUE REGIONAL ${ }^{1}$
}

\author{
Bruno de Oliveira Cruz ${ }^{2}$
}

\section{INTRODUÇÃO}

A grande recessão de 2014-2016 não só afetou fortemente o produto interno bruto (PIB) brasileiro como também teve impacto sobre a recuperação da economia após o fim da recessão, que vinha sendo bastante lenta. A economia não tem mostrado um crescimento robusto, o que tem levado a estimativas de hiato do produto perto de $5 \%$ do potencial, mesmo treze trimestres após o fim da recessão. O gráfico 1 ilustra um fato ainda mais preocupante da lenta recuperação da economia, olhando pelo lado dos componentes do dispêndio do produto: a queda do investimento é ainda mais dramática e a recuperaçáo está longe de mostrar algum sinal de melhoria.

GRÁFICO 1

Brasil: consumo, investimento e PIB (10 trim./2010-10 trim./2020)

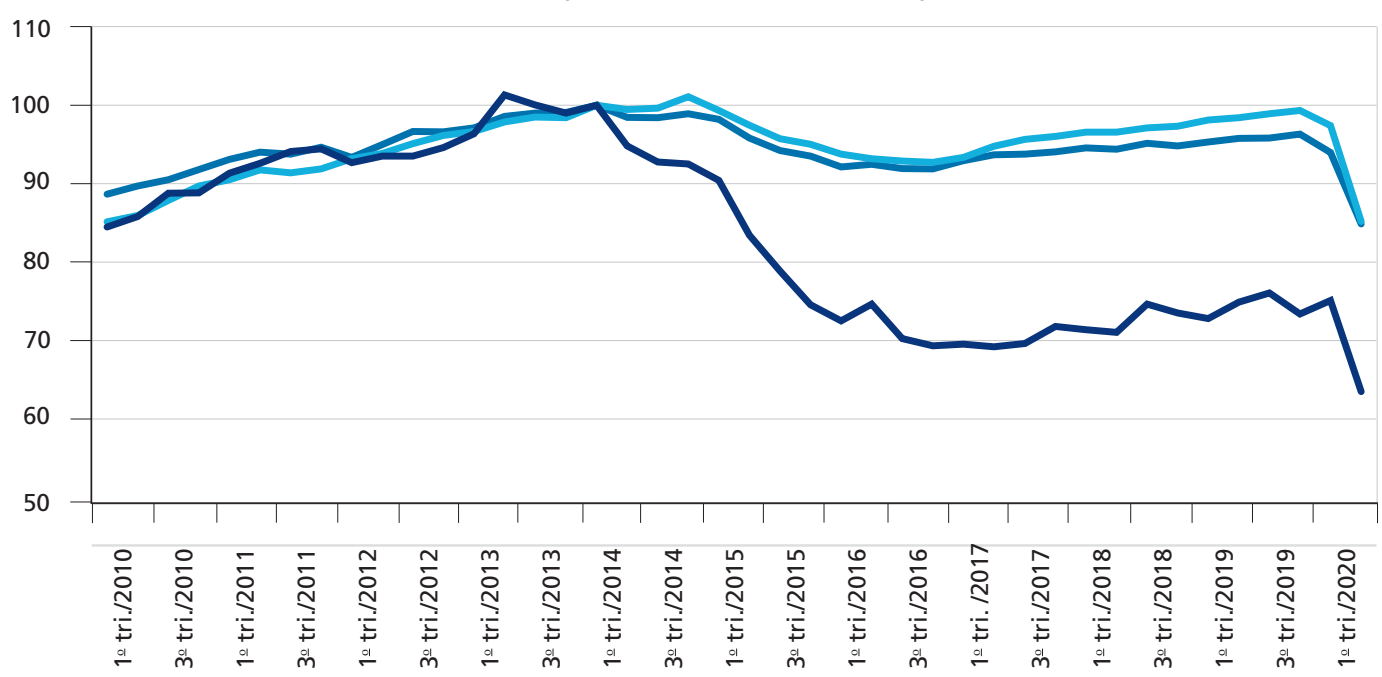

Formação bruta de capital fixo — PIB a preços de mercado

Despesa de consumo das famílias

Fonte: Contas Nacionais/Instituto Brasileiro de Geografia e Estatística (IBGE).

1 DOI: http://dx.doi.org/10.38116/brua24art1.

2. Técnico de planejamento e pesquisa na Diretoria de Estudos e Políticas Regionais, Urbanas e Ambientais (Dirur) do Ipea. 
A pandemia de Covid-19 afetou o consumo das famílias, o PIB, mas também a formação bruta de capital fixo, que já apresentava uma base bastante deprimida, caindo doze pontos percentuais e atingindo o preocupante nível de $63 \%$ do observado no primeiro trimestre de 2014. Certamente, esse comportamento ainda muito fraco do investimento tem claros impactos sobre o crescimento sustentado e do PIB potencial. A preocupaçáo com a falta de investimento das empresas brasileiras tem levantado hipóteses sobre a limitação do acesso a novas tecnologias, relegando essas empresas a uma estratégia de redução de custos, no lugar de expansão de diferenciação de produtos e maior agregação de valor. ${ }^{3}$ Portanto, entender o comportamento do investimento, tanto em nível teórico como empírico, é essencial para dimensionar caminhos para a recuperaçáo da economia brasileira, após a grave crise econômica de 2014-2016.

A pandemia atingiu também de maneira ainda mais substancial a economia brasileira, com a retração do investimento e do consumo das famílias. Desse modo, a discussão sobre a recuperaçáo da economia passa necessariamente pela diminuição do hiato do produto e pela melhoria e modernização do parque industrial. Isso posto, questiona-se: de que forma a literatura econômica tem explicado o comportamento do investimento, tanto em termos teóricos quanto empíricos?

Boucekkine e Cruz (2015) fazem uma revisão sobre a teoria do investimento, na qual apontam para alguns fatos. Primeiro, mesmo introduzindo custos de ajustamento para as firmas, a construção neoclássica tradicional não tem se mostrado empiricamente robusta. Dados em nível de firma têm mostrado que um ajuste gradual não é a norma, pois o investimento ocorre muito mais em picos do que em acréscimos marginais de máquinas e equipamento, isto é: i) em nível de firma, para o período 1972-1989, nos Estados Unidos, $25 \%$ do total do investimento deve-se ao maior pico de investimento em firma; ii) mais da metade das firmas americanas teve um crescimento no estoque de capital de $50 \%$ em um único ano; e iii) uma porcentagem elevada desse mesmo conjunto: firmas fica muito tempo sem investir ou aumentar o estoque de capital. ${ }^{4}$

Então, o desafio teórico é explicar por que há esses picos de investimento e por que as firmas ficam tanto tempo "inativas".

1) Algumas explicaçóes supõem que a relação entre investimento e o custo do capital é não linear, com um grande intervalo para inaçáo, ou seja, o estoque de capital seria menos sensível a alteraçóes na taxa de juros e no custo do capital. Haveria grande custo de ajustamento para se investir em novas máquinas.

2) Incerteza e irreversibilidade são duas outras explicações teóricas de por que as firmas não investem ou ajustam o capital mais frequentemente. A hipótese é de que, uma vez realizado o investimento, a firma não teria possibilidade de recuperar o capital, ou seja, seria um investimento irreversível. Não há desinvestimento. Além dessa situação, haveria incerteza ou do preço do bem vendido ou de algum insumo, a exemplo do preço do petróleo ou da energia. Assim, haveria a opção de a firma exercer o investimento naquele momento ou adiá-lo (Dixit e Pindyck, 1994). Sempre existe a possibilidade de adiar o investimento, pois o seu retorno tem de ser alto o suficiente para cobrir o custo do capital mais o valor da opçáo de se realizar o investimento em um período subsequente.

3. Kupfer (2019) tem defendido tal argumento no contexto do desempenho ruim da indústria brasileira e da chamada desindustrialização.

4. Para mais informações, ver Doms e Dunne (1998). 
3) Outra questão interessante, no entanto, é a hipótese de que as firmas devem ter utilização da capacidade total para poder investir. Cruz e Pommeret (2011) mostram quando há irreversibilidade e incerteza aliadas à tecnologia incorporada em máquinas. É possível haver investimento mesmo com menor utilização da capacidade instalada, pois haveria uma substituição de máquinas mais obsoletas por máquinas novas mais eficientes, que incorporam essas novas tecnologias (por exemplo, máquinas com menor consumo de energia ou computadores com maior capacidade de processamento etc.).

Por fim, tem-se o progresso tecnológico incorporado em novas máquinas. Para entender melhor seu significado, uma passagem de Greenwood e Jovanovic (2001) resume a noção de progresso tecnológico incorporado:

na realidade, avanços tecnológicos tendem a ser incorporados nas últimas versôes (vintages) do capital (máquinas e equipamentos). Isso significa que o novo capital é melhor que o antigo, não apenas porque máquinas sofrem desgaste, quando envelhecem, mas também porque o novo capital é melhor que o velho capital quando esse último era novo. Isso significa que não pode existir progresso técnico sem investimento (Greenwood e Jovanovic, 2001, p. 179-180, grifo nosso, tradução nossa).

Assim, as evidências empíricas recentes e as discussões teóricas mostram que é fundamental entender por que existem picos de investimentos e por que as firmas ficam tantos períodos sem investir, e há fortes evidências de que se deve entender que o investimento é intrinsicamente relacionado com o progresso tecnológico e a adoção de novas tecnologias. Tendo como premissa esses pontos, propóe-se entender o comportamento recente do investimento industrial, tendo como norte esses resultados teóricos e empíricos. Ao mesmo tempo, não há nesta literatura nenhum foco regional: os estudos analisam apenas a distribuição em nível micro, sem a preocupação da distribuição territorial desses investimentos. Faz-se aqui, contudo, uma descrição de proposta de pesquisa para estender essa literatura nessa direçáo, ou seja, estudar também a distribuição dos investimentos industriais no Brasil.

\section{INVESTIMENTO E PROGRESSO TÉCNICO INCORPORADO: EVIDÊNCIAS RECENTES}

Muitas das evidências recentes ao progresso técnico somente foram possíveis após a análise do comportamento do investimento em nível micro. A disponibilidade de base de dados em nível de planta e firma, além de uma capacidade computacional mais ampliada, permitiu o surgimento dessas novas evidências na dinâmica de firmas.

Notadamente, Doms e Dune (1998) mostraram que o ajustamento do estoque de capital não era gradual, como previa a teoria neoclássica tradicional. Segundo o resultado dos autores, as firmas agrupariam as decisóes de investimento em alguns períodos no tempo e ficariam bastante tempo "inativas", isto é, sem realizar qualquer incremento no estoque de capital.

Dados da Encuesta sobre Estratégias Empresariales da Fundación Sociedade Estatal de Participaciones Industriales (Sepi), compilados em Cruz (2005), mostram esse comportamento para economia espanhola. Foi selecionado o maior investimento em nível de firma, durante o período de 1990 a 1998. Agregando esses investimentos por ano e para todas as firmas, eles representaram, na média, $37 \%$ do investimento agregado do período, sendo que alguns anos chegam a representar quase metade do total do investimento realizado. Interessante também destacar que o comportamento se mantém quando são excluídos os investimentos 
em edificaçôes e instalações, isto é, considerando apenas máquinas e equipamentos. ${ }^{5}$ Esses resultados apontam para o fato de que os "picos de investimento" parecem ser extremamente relevantes para o comportamento agregado da ampliação do estoque de capital. Seria no mínimo importante para gestores e formuladores de política entenderem melhor as variáveis que explicariam esses picos de investimento e longo período de inaçáo das firmas. Assim, no nível da firma, são observados "picos de investimentos", ou seja, um aumento abrupto do estoque de capital. O grande desafio teórico tem sido o de explicar tais "picos de investimento" e entender qual o impacto macroeconômico desse comportamento em nível de firma.

Boucekkine e Cruz (2015) fazem uma revisão desses trabalhos sobre investimento e as implicaçóes macroeconômicas. Seguindo uma linha de custo de ajustamento não linear, Caballero e Engle (1999) realizam uma modelagem bottom-up para agregar as decisóes de investimento, a partir de um modelo $(S, s)$, no qual os custos de ajustamentos são assimétricos. Cooper, Haltiwanger e Power (1999) mostram que a exclusão da idade dos equipamentos leva à sistemática subestimação das previsóes de investimentos agregados no Estados Unidos. Cruz e Pommeret (2011) mostram, a partir de um modelo de investimento irreversível, que a incerteza e as mudanças tecnológicas incorporadas em novas máquinas podem gerar picos de investimento e períodos de ausência de investimento.

Outra linha de debate importante seriam os efeitos macroeconômicos desses picos de investimentos: modelos Real Business-Cycle (RBC) tendem afirmar que os picos de investimento seriam irrelevantes para o comportamento da economia, pois sua agregação geraria uma suavizaçáo do comportamento do investimento em nível macroeconômico (Thomas, 2002). No entanto, existem críticas a esse impacto suavizado em nível macroeconômico: Sveen e Weinke (2007) mostram que os picos de investimento têm grande relevância para os ciclos econômicos, pois os modelos tradicionais de RBC náo captariam de forma correta a dinâmica da economia. Ademais, os picos de investimento tendem a ser fortemente pró-cíclicos (Gourio e Kashyap, 2007).

No Brasil, apesar da disponibilidade de dados, poucos trabalhos têm se concentrado na questão, com enfoque mais detalhado dos picos de investimento e seu impacto. Uma das poucas exceções é Messa (2015), focando apenas no impacto de picos de investimento, em nível microeconômico, sobre a produtividade de firmas no Brasil. Contudo, os estudos disponíveis tendem desconsiderar os fatores para explicação dos picos, ainda mais a questão regional. Portanto, há uma lacuna importante para se compreender a dinâmica da economia brasileira para os próximos anos.

Assim, a busca de padrão no comportamento desses picos de investimento levanta, também, um questionamento sobre a existência de algum padrão espacial ou territorial nessa dinâmica. A literatura regional brasileira tem apesentado fortes evidências empíricas de que há uma desconcentração limitada da indústria no Centro-Sul. ${ }^{6}$ Assim, também é urgente um estudo detalhado da dinâmica dos investimentos em nível de firmas/plantas e padrão territorial desses investimentos. Oliveira e Cruz (2020) mostram ainda que apenas ganhos de produtividade não são suficientes para fazer com que o PIB per capita das regióes mais pobres chegue ao limite definido de $75 \%$ do PIB per capita nacional.

5. 0 segundo maior episódio de investimento geralmente se localiza num período subsequente ao maior investimento, 0 que sugere serem parte de um mesmo projeto, apenas com defasagem ao longo do ano.

6. Entre outros, Diniz (1993) foi um dos primeiros autores a destacar esse processo de desconcentração de atividades. 
Cruz (2005) mostra ainda que os picos de investimento observados na economia espanhola estão fortemente relacionados com a inovação, seguindo o trabalho de Cooper, Haltiwanger e Power (1999). A partir de modelo de sobrevivência/duração, estima-se que a probabilidade de uma firma realizar um pico de investimento é crescente ao longo do tempo. Isto é, após uma grande aquisição de máquinas e equipamentos, a probabilidade de outra grande compra semelhante seria crescente ao longo do tempo. Em termos técnicos, observa-se que uma inclinaçáo positiva da curva de probabilidade (harzard function) da realizaçáo do pico de investimento pode ser explicada pela obsolescência tecnológica do estoque de capital, ou seja, quanto mais longínquo o primeiro evento de um pico de investimento, mais provável se torna a realização do investimento. Essa probabilidade é ainda mais elevada caso a firma declare ter realizado alguma inovação tecnológica. Esta evidência reforça a noção de progresso tecnológico incorporado ou no mínimo a forte correlação entre investimento e inovação.

Para se compreender um pouco mais a noção de progresso técnico incorporado, podemos destacar dois grandes artigos escritos por Solow (1956; 1960). Para Solow (1956), o progresso tecnológico seria desincoporado. Para o autor, o avanço tecnológico é como um maná: assim todos os fatores de produção melhorariam a produtividade, não apenas o capital, o fator trabalho também estaria sempre mais produtivo.

Em contraste, Solow (1960) modela a economia segundo a hipótese de que o avanço tecnológico está incorporado em novas máquinas, ou seja, o estoque de capital é heterogêneo e somente tendo acesso à "última versáo" a firma poderia conseguir se beneficiar do progresso técnico. Em termos mais simples, somente comprando o último iPhone é possível ter acesso a todas a essas inovaçóes. É possível dividir os modelos com tecnologias incorporadas em novas máquinas em algumas famílias, conforme abaixo.

- Modelo vintage com redução de insumos: a cada período tem máquinas mais eficientes na redução do consumo de insumos (menos trabalho para usar a máquina ou menor consumo de energia) para a mesma quantidade de produto/unidade de tempo.

- Modelo vintage com aumento de produção: a cada período as máquinas produzem mais utilizando basicamente a mesma quantidade de insumos (por exemplo, melhoria de processadores).

- Modelos sem vintage, mas, em cada período, o investimento realizado (compra de máquinas e equipamentos) fica mais eficientes na geração de produto (Boucekkine e Cruz, 2015).

Isso significa que, em termos de eficiência das novas máquinas, o preço relativo do capital será menor que no ano anterior. Por exemplo, tome a capacidade de processamento de um computador em 1980 e hoje. Em termos de um byte de processamento, as máquinas atuais são muito mais eficientes e baratas. ${ }^{7}$ Nos Estados Unidos, a queda relativa de preços do capital, ou seja, a estimativa da taxa de progresso técnico incorporado, é de $3 \%$. Para o Brasil, o gráfico 2 mostra uma estimava da queda relativa em aproximadamente $2,5 \%$ ao ano, comparando os dados do Índice de Preços por Atacado (IPA) de máquinas e equipamentos da Fundaçáo Getulio Vargas (FGV) com o Índice Geral de Preços - Disponibilidade Interna (IGP-DI) da FGV.

7. Greenwood, Hecortwitz e Kruseel (1997) mostram que dois terços do crescimento econômico nos Estados Unidos no pós-guerra devem-se à tecnologia incorporada em novas máquinas. 
GRÁFICO 2

Brasil: evolução relativa do IPA de máquinas e equipamentos e o IGP-DI (1970-2008)

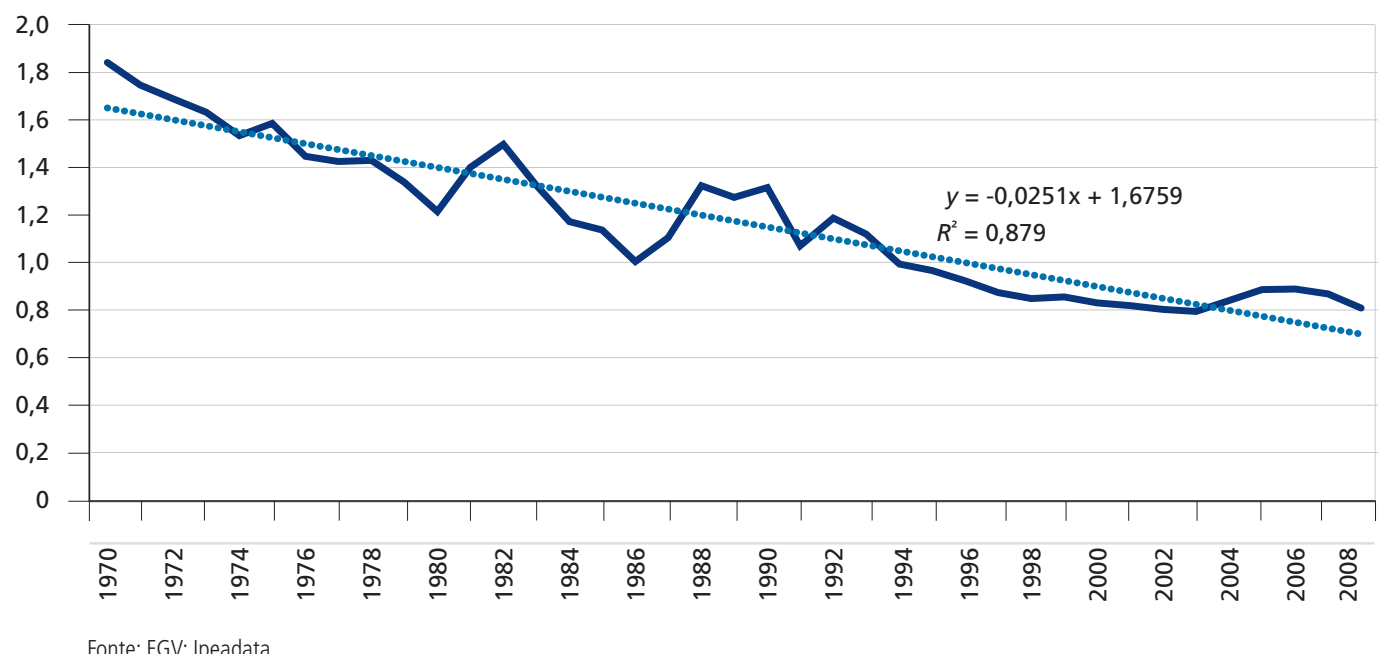

Obviamente, um modelo de tecnologia incorporado pode explicar a queda do preço relativo dos bens de capital, e parece ser promissor tentar utilizar esses modelos para explicar o processo de difusão da "internet das coisas" ou mesmo digitalizaçáo de empresas. O preço dos processos e equipamento de compartilhamento tem ficado cada vez menor, e isso é explicado pela melhor qualidade das novas máquinas.

A literatura sobre esse tópico no Brasil parece ser escassa, ou seja, raros são os trabalhos sobre o impacto do progresso incorporado para o país. Seria interessante utilizar essa discussão em especial quando se debate a estagnação da produtividade da economia brasileira e ao mesmo tempo a redução da taxa dos investimentos. Conforme destacado, há o trabalho de Messa (2015), mostrando o impacto de picos investimento na produtividade de firmas no Brasil, no qual tais picos não são importantes para os ganhos de produtividade das firmas, o que aparentemente seria contraditório com a expansão e melhoria do parque tecnológico. Os resultados podem indicar um certo grau de aprendizagem e efeitos distribuídos ao longo do tempo, náo testados pelos autores. O resultado encontrado por Messa (2015), de queda ou de que os ganhos produtividade não são imediatos também é um efeito bastante comum na literatura. Uma explicação para esse fenômeno é o chamado processo de aprendizado e difusão. Quando uma nova tecnologia está disponível, as firmas não conhecem toda a sua capacidade e precisam aprender a atingir o seu potencial máximo, e ela precisa também ficar conhecida para as demais firmas, em um processo de difusão.

\section{INSERINDO A DIMENSÃO REGIONAL}

A metodologia para realizar o estudo pressupóe o acesso às bases de dados do IBGE, como a Pesquisa Industrial Anual (PIA) e a Pesquisa Industrial de Inovação Tecnológica (Pintec), em nível de firma. Dessa forma, poderiam ser acompanhadas firmas ao longo do tempo, analisando os padrôes de investimento. Será necessário construir uma proxy para o estoque de capital para o ano de 1996, de início da nova PIA, e acompanhar o padrão dos investimentos ao longo do tempo.

Uma vez constatado e observado o padrão de investimentos, deve-se tentar explicá-lo, ou seja, procurar identificar variáveis que possam fornecer elementos explicativos do investimento em nível de firmas no Brasil. Assim, pode-se almejar alguma forma de agregação do comportamento micro para subsidiar o entendimento do investimento em 
nível macroeconômico. Cooper, Haltiwanger e Power (1999) desenvolvem um modelo de duração para estimar o padrão de reposição das máquinas e equipamentos nos Estados Unidos, e Cruz (2005) utiliza a mesma metodologia para estimar o comportamento dos investimentos em nível de firma para a economia espanhola. Os modelos de duraçáo tentam explicar qual a probabilidade de um evento ocorrer dado o padráo observado nos períodos anteriores. Assim, caso venham a ser observados os investimentos abruptos, podem ser estimadas quais variáveis influenciariam esses investimentos.

Uma terceira parte do estudo seria identificar algum tipo de característica, local ou regional, que influencie o padrão de investimentos observados. Dado que é possível reconhecer o endereço das empresas que realizaram os investimentos, pode-se tentar territorializar o comportamento em nível de firma. A primeira e mais simples tarefa será a de construir um mapa dos investimentos ano a ano para empresas que possuem apenas uma unidade local. Para empresas com mais de uma, existem duas alternativas para se criar proxies dos investimentos: i) dados de financiamento do Banco Nacional de Desenvolvimento Econômico e Social (BNDES) em nível de firma e local de aplicação dos recursos, caso não haja informação suficiente na base do BNDES; ii) pode-se estimar uma proxy de distribuição dos investimentos pela distribuição das atividades por atividades locais. Desse modo, tendo identificado características agregadas macroeconômicas, setoriais e locais do investimento e influência desses na ocorrência dos picos de investimentos, seria possível estimar eventuais efeitos regionais. Em suma, poder-se-ia buscar identificadas regióes com maior potencial de crescimento ou de estímulo para investimentos.

Em resumo, há evidências, em nível microeconômico de que o investimento não se comporta de forma suave e gradual. Essas evidências existem para diversos países e o Brasil também parece um desses casos. A literatura a esse respeito é vasta, contudo, não há um foco territorial ou regionalizado. Portanto, esta pesquisa pretende entender esse comportamento não apenas no nível microeconômico, mas também sua distribuição territorial.

\section{REFERÊNCIAS}

BOUCEKKINE, R.; CRUZ, B. Technological progress and investment: a non-technical survery. Bukavu Journal of Economics and Social Sciences, 2015.

CABALLERO, R.; ENGLE, E. Explaining investment dynamics in US manufacturing: a aeneralized (S, s) approach. Econometrica, v. 67, p. 783-826, July 1999.

COOPER, R., HALTIWANGER, J., POWER, L. Machine replacement and the business cycle: lumps and bumps. American Economic Review, v. 89, n. 4, p. 921-946, 1999.

CRUZ, B. Essays on investment and technological adoption. 2005. Tese (Doutorado) Université Catholique de Louvain, Louvain, 2005.

CRUZ, B. ; POMMERET, A. Embodied technology adoption under uncertainty. In: BOUCEKKINE, R.; HRITONENKO, N.; YATSENKO Y. (Eds.). Optimal control of age-structured populations in economy, demography and the enviroment. New York: Routledge, 2011.

DINIZ, C. C. Desenvolvimento poligonal no Brasil: nem desconcentração, nem contínua polarização. Nova Economia, v. 3, n. 1, p. 35-64, 1993.

DIXIT, A.; PINDYCK, R. Investment under uncertainty. Princeton: Princeton University Press, 1994. 
DOMS, M.; DUNNE, T. Capital adjustment patterns in manufacturing plants. Review of Economic Dynamics, v. 1, n. 2, p. 409-429, 1998.

GOURIO, F.; KASHYAP, A. K. Investment spikes: new facts and a general equilibrium exploration. Journal of Monetary Economics, v. 54, p. 1-22, 2007.

GREENWOOD, J.; JOVANOVIC, B. Accounting for growth. In: HULTEN, C. D.; HARPER, M. New developments in productivity analysis. Chicago: University of Chicago Press, 2001.

GREENWOOD, J.; HERCOWITZ, Z.; KRUSELL, P. Long-run implications of investment-specific technological change. American Economic Review, v. 87, n. 3, 1997.

KUPFER, D. A doença industrial brasileira. Valor Econômico, 14 out. 2019.

MESSA, A. Impacto dos investimentos sobre a produtividade das firmas industriais brasileiras In: DE NEGRI, F.; CAVAlCANTI, L. (Org.). Produtividade no Brasil: desempenho e determinantes. Brasília: Ipea, 2015. v. 2.

OLIVEIRA, C.; CRUZ, B. Impactos regionais de choques de produtividade e reduçáo de desigualdades: o caso da regiáo Nordeste. Brasília: Ipea, 2020. Mimeografado.

SOLOW, R. A contribution to the theory of economic growth. The Quarterly Journal of Economics, v. 70, p. 65-94, 1956.

Investment and technical progress. In: ARROW, K. J.; KARLIN, S.; SUPPES, P. Mathematical methods in the social sciences. Redwood City, California: Stanford University Press, 1960. p. 48-93.

SVEEN, T.; WEINKE, L. Lumpy investment, sticky prices, and the monetary transmission mechanism. Journal of Monetary Economics, v. 54, p. 23-36, 2007.

THOMAS, J. Is lumpy investment relevant for the business cycle? Journal of Political Economy, v. 110, n. 3, p. 508-534, 2002. 


\title{
UMA ANÁLISE DA DISTRIBUIÇÃO REGIONAL DO FUNDEB EM 2007 E 2017
}

\author{
Kalinca Léia Becker
}

\section{INTRODUÇÃO}

O acesso ao sistema gratuito de educaçáo básica é um direito de todos os brasileiros, conforme o art. 208 da Constituição Federal de 1988, a qual também estabelece que a União, os Estados e os municípios devem destinar $25 \%$ da arrecadação com impostos para manutenção e desenvolvimento do sistema público de ensino.

O Fundo de Manutenção e Desenvolvimento da Educação Básica e de Valorização dos Profissionais da Educação (Fundeb), instituído em 2007 com vigência até 31 de dezembro de 2020, foi criado para garantir um investimento mínimo por aluno e também promover a distribuição dos recursos em todo o território nacional.

Assim, ao longo de 2020, discutiu-se a possibilidade de tornar esse fundo permanente, e também a alteração da lógica de distribuição e alocação dos recursos. Isso porque a distribuiçẫo do fundo se dava entre os municípios do mesmo estado, de modo que os recursos ficavam concentrados naqueles com maior arrecadação. Além disso, as outras fontes municipais de financiamento da educação não eram levadas em consideração na distribuição dos recursos, e a complementação da União era realizada em nível estadual. Dessa forma, tanto municípios ricos como pobres de um mesmo estado recebiam o mesmo valor por aluno. Isso poderia ser considerado um desvio de focalizaçáo da política do Fundeb se considerarmos que o objetivo é direcionar os recursos para os municípios que mais precisam.

Diante disso, este texto faz uma breve análise da distribuição do Fundeb por aluno, comparando com o produto interno bruto (PIB) per capita dos municípios brasileiros em 2007 e 2017.

\section{FUNDEB}

A Lei no 9.424, de 1996, definiu o Fundo de Manutenção e Desenvolvimento do Ensino Fundamental e de Valorizaçáo do Magistério (Fundef), destinado inicialmente ao ensino fundamental e médio. Em 2007, foi substituído pelo Fundeb, conforme a Lei

1. DOI: http://dx.doi.org/10.38116/brua24art2

2. Professora na Universidade Federal de Santa Maria (UFSM); e pesquisadora do Programa de Pesquisa para o Desenvolvimento Nacional (PNPD) na Diretoria de Estudos e Políticas Regionais, Urbanas e Ambientais (Dirur) do Ipea. 
no 11.494 , que estendeu o fundo a todas as redes de ensino fundamental, incluindo educaçáo infantil e educação para jovens e adultos (EJA).

O Fundeb consiste em uma conta estadual na qual os municípios depositam $20 \%$ da receita arrecadada com oito tributos específicos, ${ }^{3}$ e a União complementa os recursos dos fundos que ficaram com o menor valor por aluno. $\mathrm{O}$ valor da conta do Fundeb estadual é distribuído aos municípios de acordo com o número de alunos matriculados na rede pública de ensino básico, multiplicado por um fator de ponderação. ${ }^{4}$ Alguns estudos apontam evidências de que o fundo contribuiu para aumentar a eficiência da administração escolar dos municípios, em virtude da descentralização dos recursos, embora esse resultado não seja observado para todos os municípios (Sousa, Cribari-Neto e Stosic, 2005; Gonçalves e França, 2013).

Em uma conta específica para educação, os municípios devem destinar no mínimo 5\% do valor arrecadado com os oito tributos do Fundeb, a fim de cumprir o que está estabelecido na Constituição Federal de 1988, na qual estados e municípios devem destinar pelo menos $25 \%$ de sua receita orçamentária para a manutenção e o desenvolvimento do sistema público de educação básica. Nessa conta também devem ser depositados no mínimo $25 \%$ da receita arrecadada com os demais impostos. ${ }^{5}$ Os arts. 70 e 71 da Lei de Diretrizes e Bases da Educação Nacional (LDB) definem como o município pode despender os recursos dessa conta a fim de investir na rede pública de ensino. No caso dos recursos do Fundeb, esta definição está nos arts. 21, 22 e 23 da Lei no 11.494/2007.

\section{DISTRIBUIÇÃO REGIONAL DO FUNDEB E DO PIB DOS MUNICÍPIOS (2007 E 2017)}

A figura 1 apresenta a distribuição regional do Fundeb por aluno e do PIB per capita dos municípios em 2007 e 2017. Os valores do Fundeb são disponibilizados pela Secretaria do Tesouro Nacional (STN), e o número de matrículas foi obtido no Censo Escolar, realizado pelo Instituto Nacional de Estudos e Pesquisas Educacionais Anísio Teixeira (Inep). O PIB per capita é disponibilizado pelo Instituto Brasileiro de Geografia e Estatística (IBGE). Os valores estáo em logaritmo e, no caso de 2007, foram deflacionados para preços de 2017, utilizando-se como deflator o Índice Nacional de Preços ao Consumidor (INPC). Para os municípios sem informação, atribuiu-se o valor médio da microrregiáo.

Em 2007, a média do Fundeb por aluno era $\mathrm{R} \$ 2.665,11$ e, em 2017, esse valor era $\mathrm{R} \$ 5.552,48$, o que representa um aumento de $108 \%$. O valor mínimo investido por aluno passou de $\mathrm{R} \$ 284,29 \mathrm{em} 2007$ para $\mathrm{R} \$ 2.298,47 \mathrm{em} 2017$. O intervalo entre o valor mínimo e o máximo do Fundeb nos municípios, para o cálculo dos intervalos dos mapas, reduziu-se de 4,80 para 2,68, o que, em termos gerais, pode ser um indicativo de que houve uma melhora na distribuição dos recursos do fundo em termos da média nacional nos dez anos do Fundeb.

3. São eles: Imposto sobre Produtos Industrializados (IPI), Imposto sobre Circulação de Mercadorias e Serviços (ICMS), Lei Kandir, Imposto Territorial Rural (ITR), Fundo de Participação dos Municípios (FPM), Imposto sobre a Propriedade de Veículos Automotores (IPVA), Fundo de Participação dos Estados e do Distrito Federal (FPE) e Imposto sobre Transmissão Causa Mortis e Doação (ITCMD).

4. 0 fator de ponderação representa quanto vale cada matrícula. Por exemplo, uma matrícula no ensino integral precisa de mais recursos em relação a uma matrícula no ensino parcial. Atualmente há dezenove fatores de ponderação, e a base de cálculo é uma matrícula no ensino fundamental urbano nas séries iniciais. Disponível em: <https://bit.ly/2TDzm5z>.

5. Quais sejam: Imposto Predial e Territorial Urbano (IPTU), Imposto sobre a Transmissão de Bens Imóveis (ITBI), Imposto de Renda Retido na Fonte (IRRF) e Imposto sobre Serviços (ISS). 
FIGURA 1

Mapas de distribuição do Fundeb por aluno e PIB per capita (2007 e 2017)

$1 \mathrm{~A}$ - Fundeb por aluno (2007)

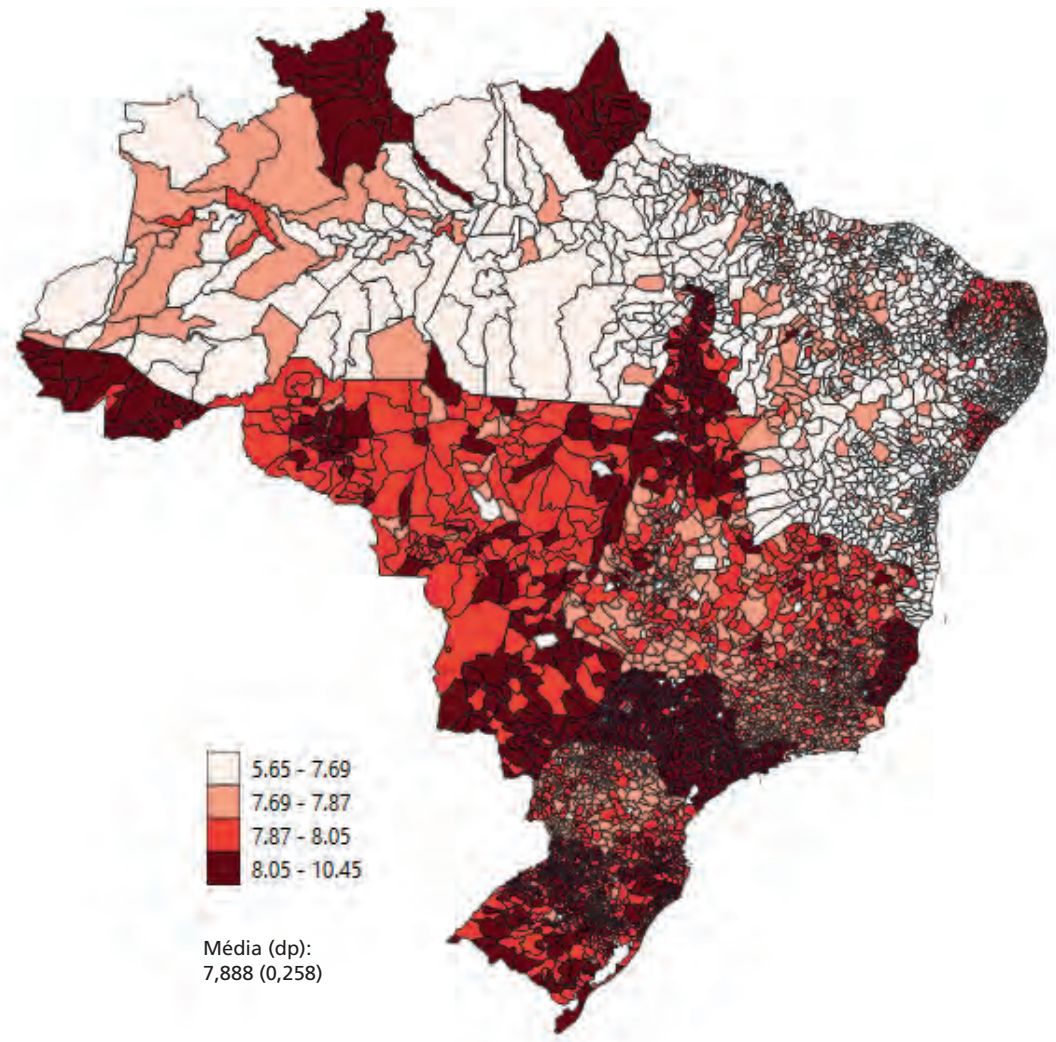

1B - PIB per capita (2007)

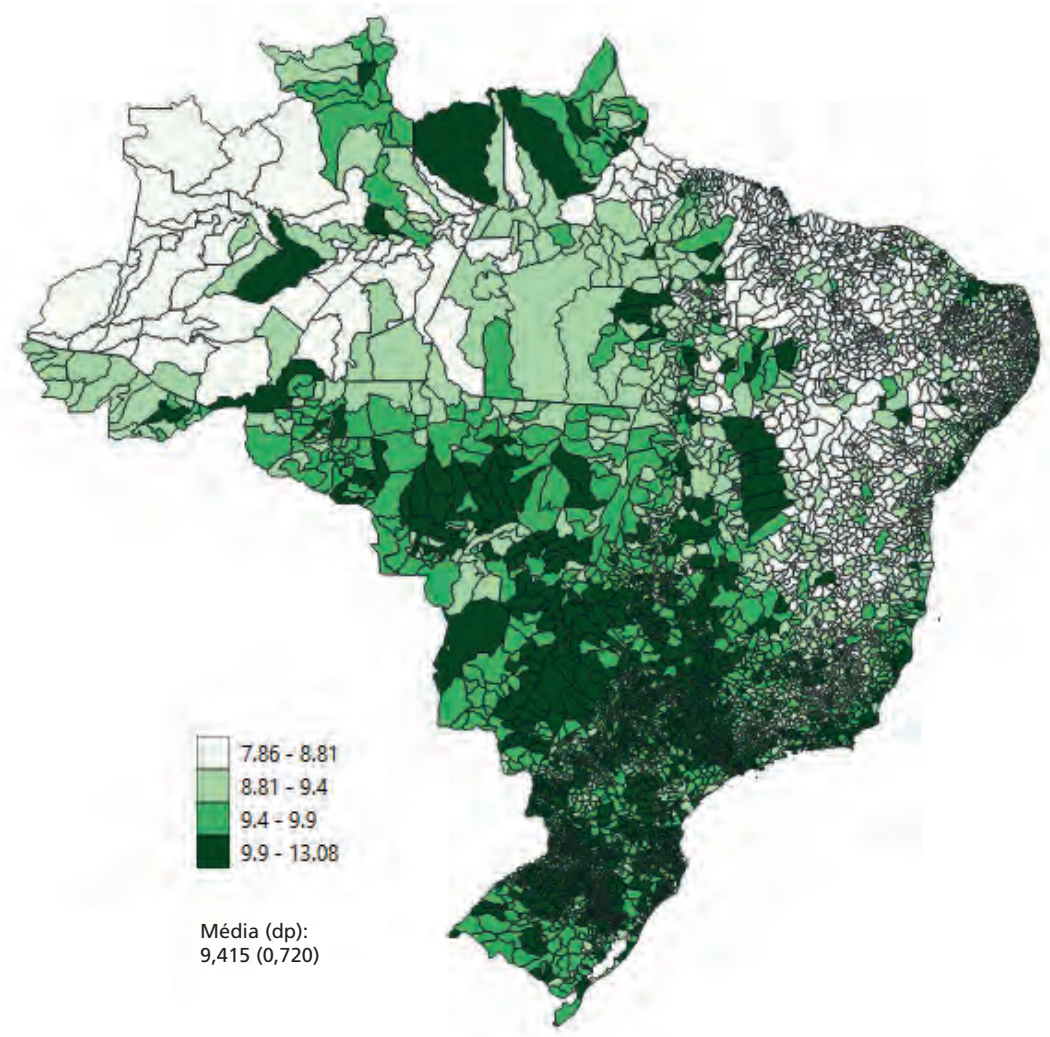




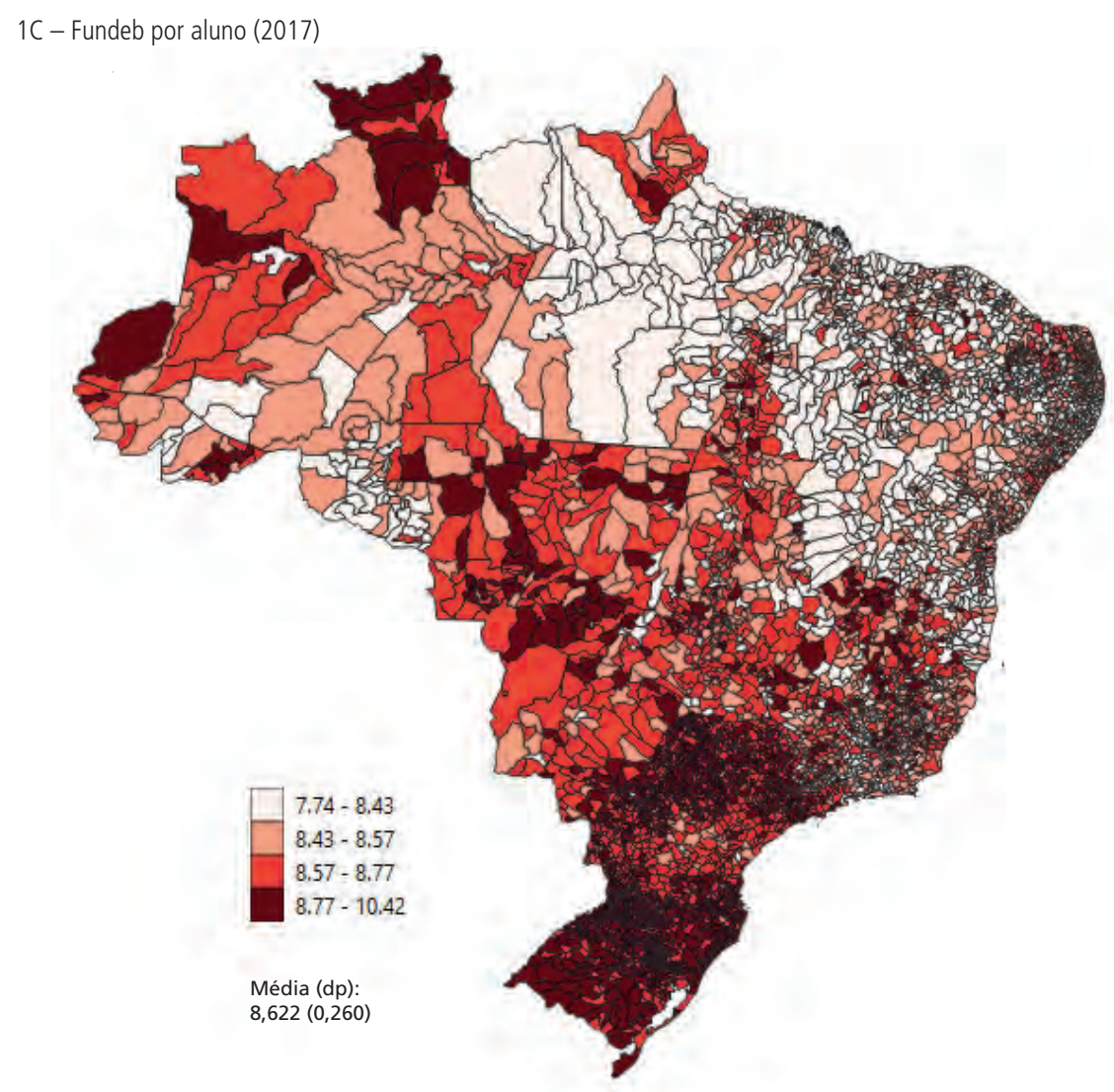

1D - PIB per capita (2017)

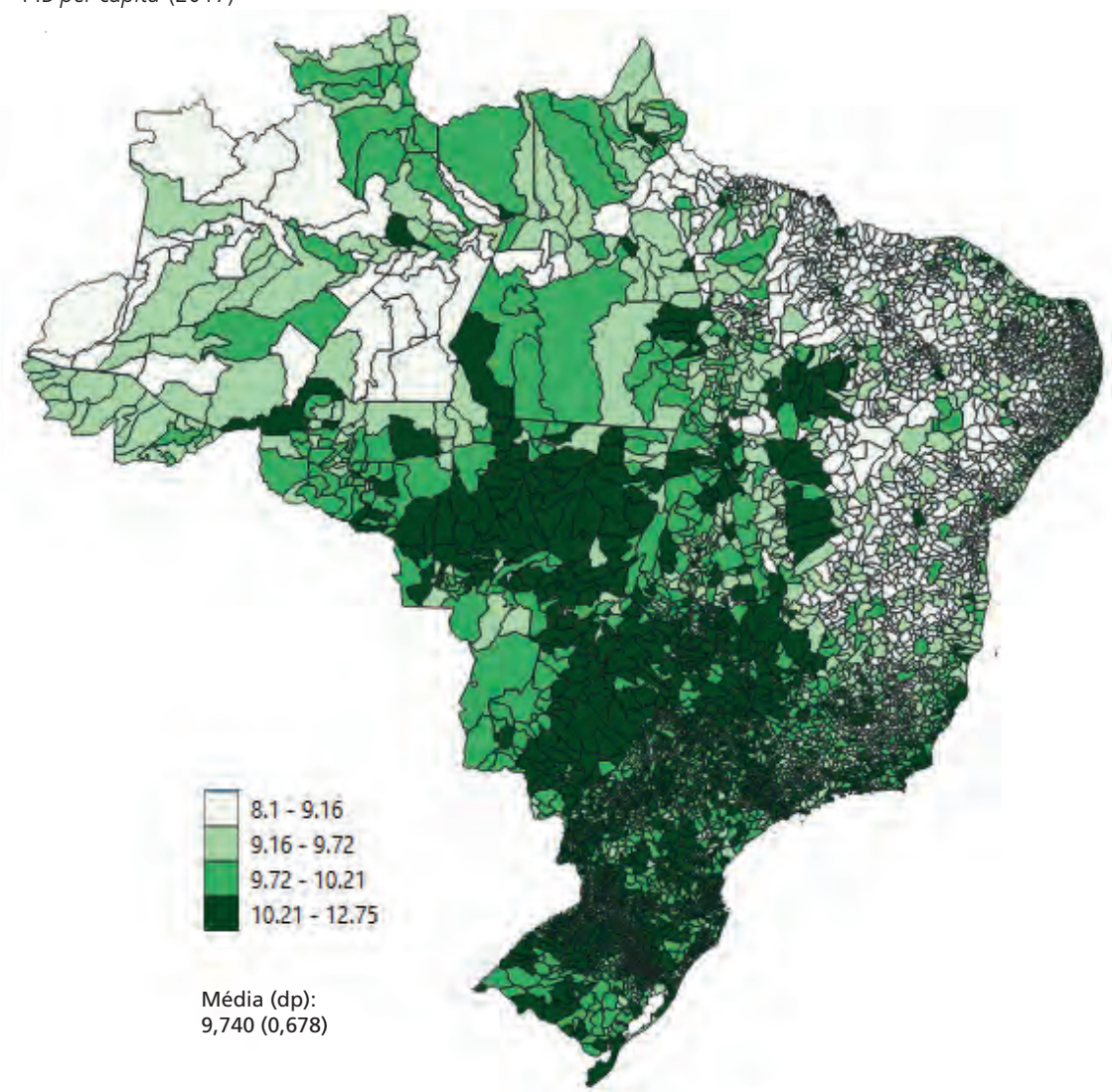

Fonte: STN, Inep e IBGE.

Obs.: 1. Os valores do Fundeb por aluno e do PIB per capita estão medidos em logaritmo. Os valores entre parênteses são o desvio-padrão da média (dp).

2. Figura cujos leiaute e textos não puderam ser padronizados e revisados em virtude das condições técnicas dos originais (nota do Editorial). 
Nos mapas da figura 1, contudo, observa-se que, em ambos os anos, os maiores valores do Fundeb por aluno estão nos municípios dos estados das regiōes Sul e Sudeste e os menores valores encontram-se nas regiōes Norte e Nordeste, que coincidem também com a distribuição dos valores do PIB per capita.

A fim de analisar de forma mais precisa as concentraçóes dos valores do Fundeb por aluno e do PIB per capita no território nacional, a figura 2 apresenta os mapas de clusters LISA (Local Indicator of Spatial Association) e o indicador I de Moran, que permitem identificar a autocorrelaçáo local e os padróes de associaçáo espacial (clusters espaciais). O sinal positivo da estatística I de Moran, quando significativo, indica que os dados estão concentrados nas regióes; por sua vez, o sinal negativo indica dispersão nos dados. Quanto mais próximo de 1 , maior a concentração, e quanto mais próximo de -1 , mais dispersos estão os dados (Almeida, 2012). Os mapas de clusters LISA permitem observar se municípios com alto (ou baixo) valor do Fundeb por aluno são rodeados também por municípios com alto (ou baixo) valor do Fundeb por aluno. Assim, os mapas permitem identificar quatro categorias de associação espacial: alto-alto, baixo-baixo, alto-baixo e baixo-alto. Da mesma forma, foram construídos mapas de cluster para o PIB per capita.

\section{FIGURA 2}

Mapas de clusters do Fundeb por aluno e PIB per capita (2007 e 2017)

2A - Fundeb por aluno (2007)

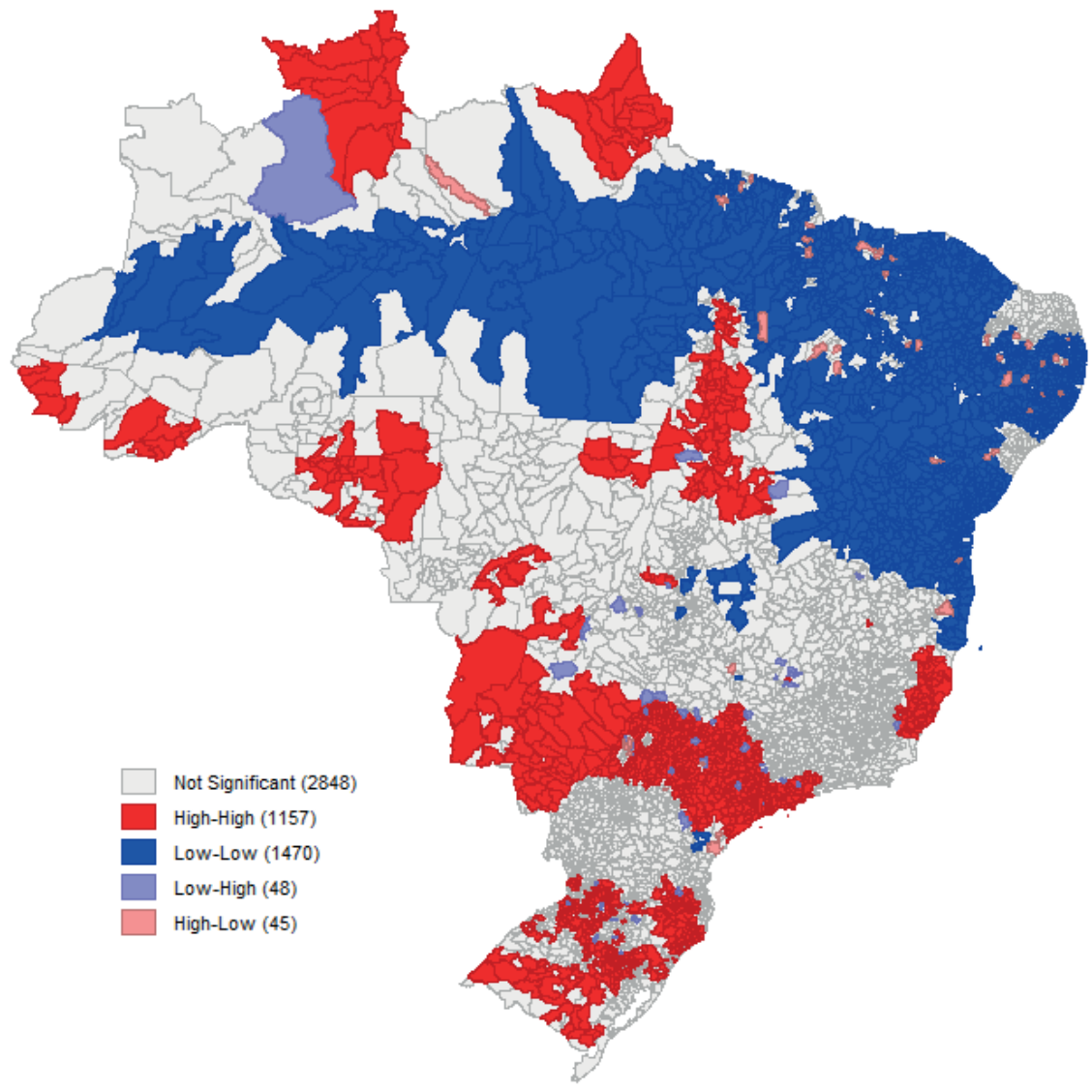




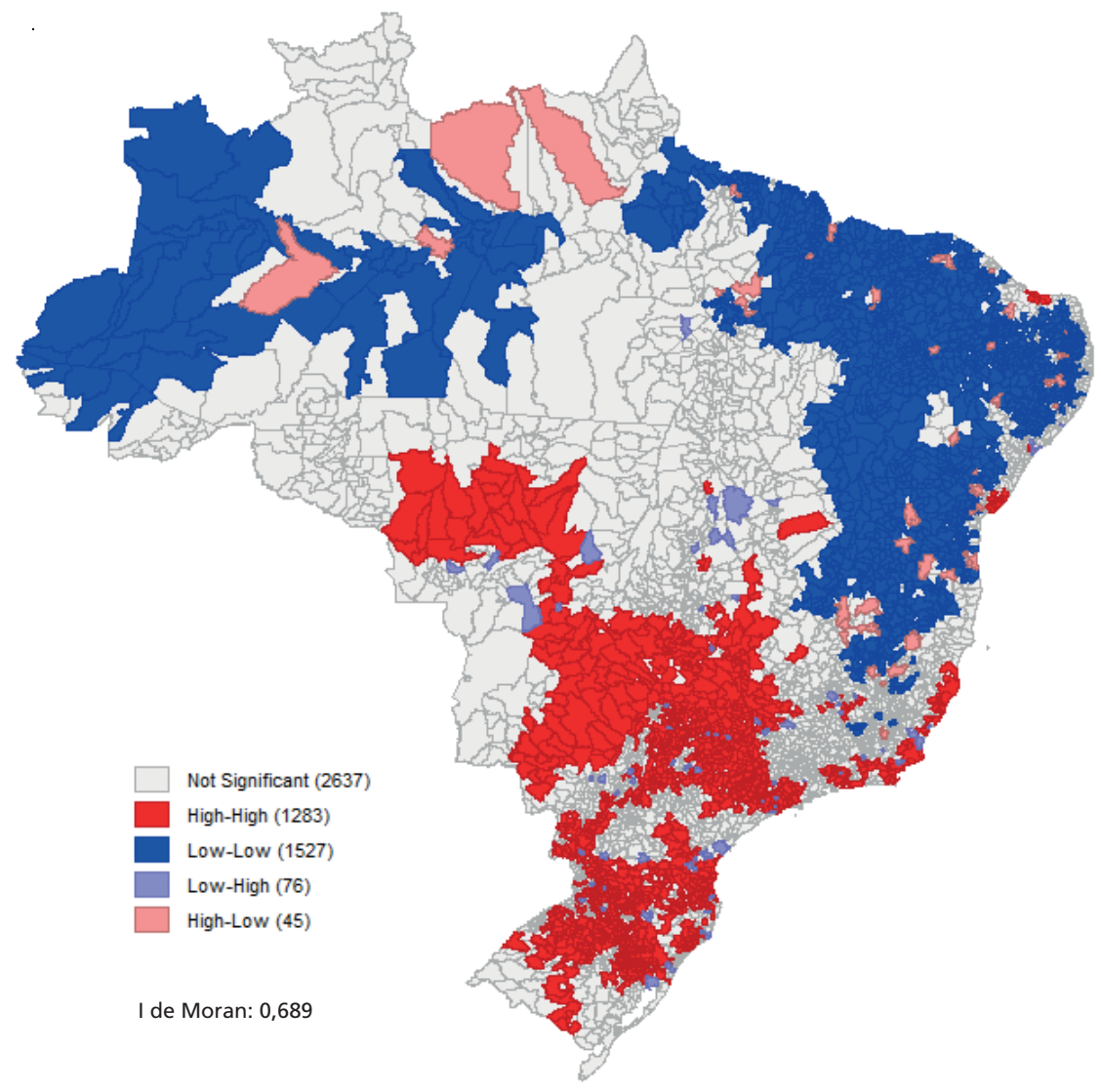

$2 C$ - Fundeb por aluno (2007)

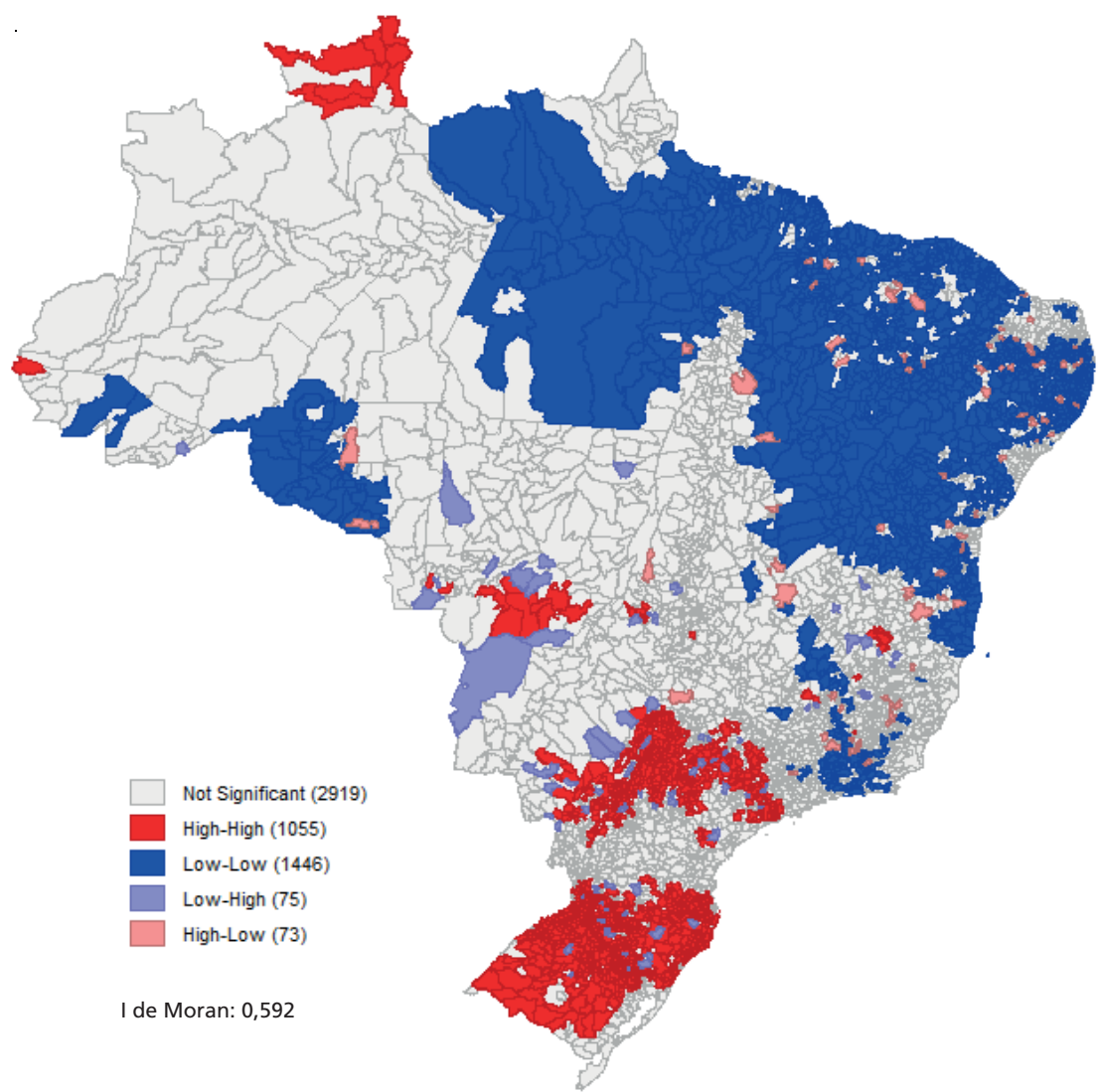




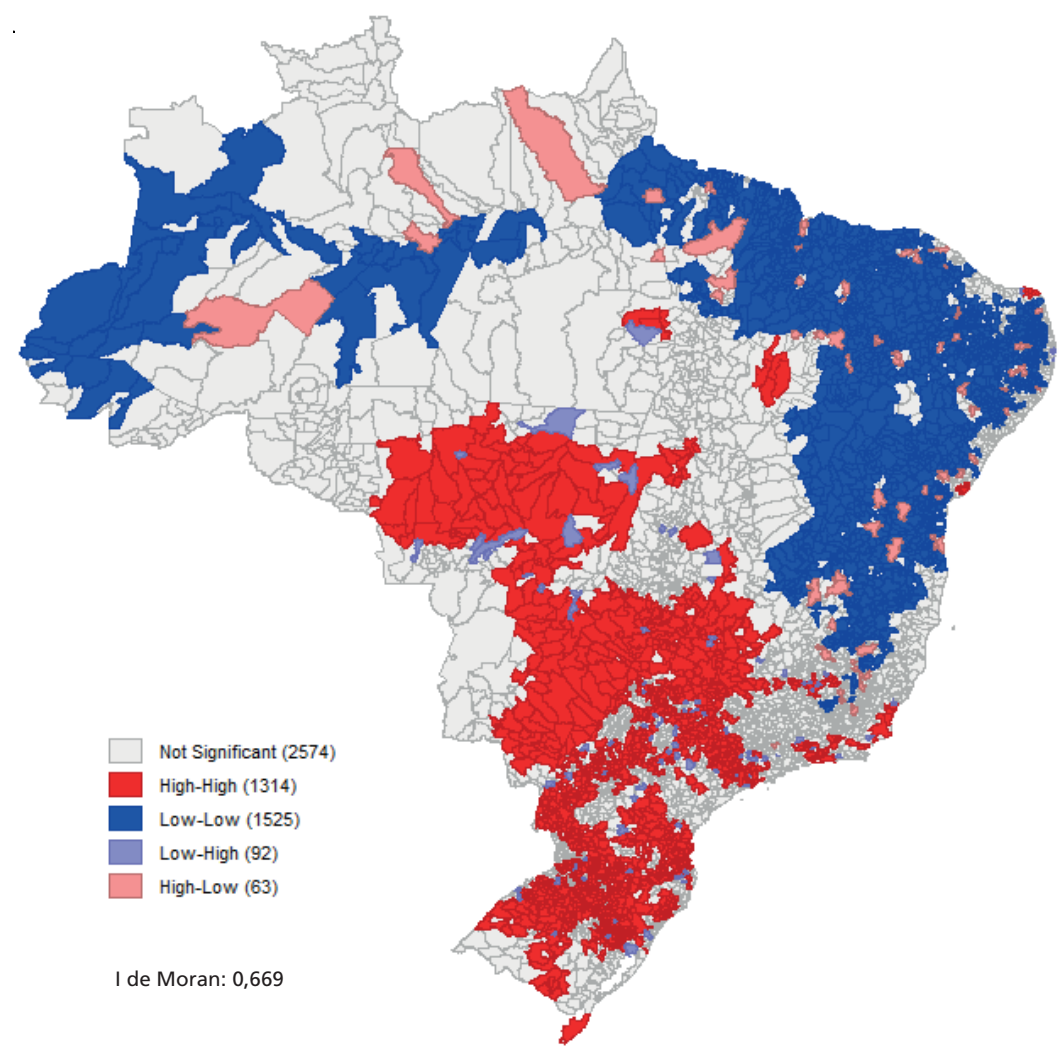

Fonte: STN, Inep e IBGE.

Obs.: Figura cujos leiaute e textos não puderam ser padronizados e revisados em virtude das condiçôes técnicas dos originais (nota do Editorial).

Os resultados confirmam a análise visual da figura 1, de modo que o sinal positivo da estatística I de Moran mostrou que os dados estão concentrados nas regióes. Os clusters do tipo alto-alto estão, principalmente, nos estados do Sul e Sudeste, o que revela que municípios com elevado Fundeb por aluno são rodeados por municípios que também possuem elevado valor do fundo. No entanto, os clusters do tipo baixo-baixo estão nas regióes Norte e Nordeste.

Havia um cluster do tipo baixo-baixo nos municípios do estado do Amazonas em 2007, porém tal concentração não foi significativa em 2017. Da mesma forma, o cluster do tipo alto-alto nos municípios do estado do Mato Grosso do Sul, observado em 2007, não se mostrou significativo em 2017. O número de municípios no cluster alto-alto no estado de São Paulo reduziu-se entre 2007 e 2017 e, no caso do Rio Grande do Sul, houve um aumento nesse número.

Assim, pode-se observar que, ao longo dos dez anos do Fundeb, houve algumas alteraçóes na alocação dos recursos dentro dos estados, porém não houve grandes mudanças da distribuição do fundo considerando todo o território nacional.

Além disso, a disponibilidade de recursos para o Fundeb parece coincidir com a riqueza dos estados, mensurada por meio do PIB per capita. Nesse sentido, a figura 3 apresenta o mapa de cluster LISA bivariado, de modo a observar se municípios com alto (ou baixo) valor do Fundeb por aluno sáo rodeados por municípios com alto (ou baixo) PIB per capita. 
FIGURA 3

Mapas de clusters bivariados Fundeb por aluno versus PIB per capita

3 A -2007

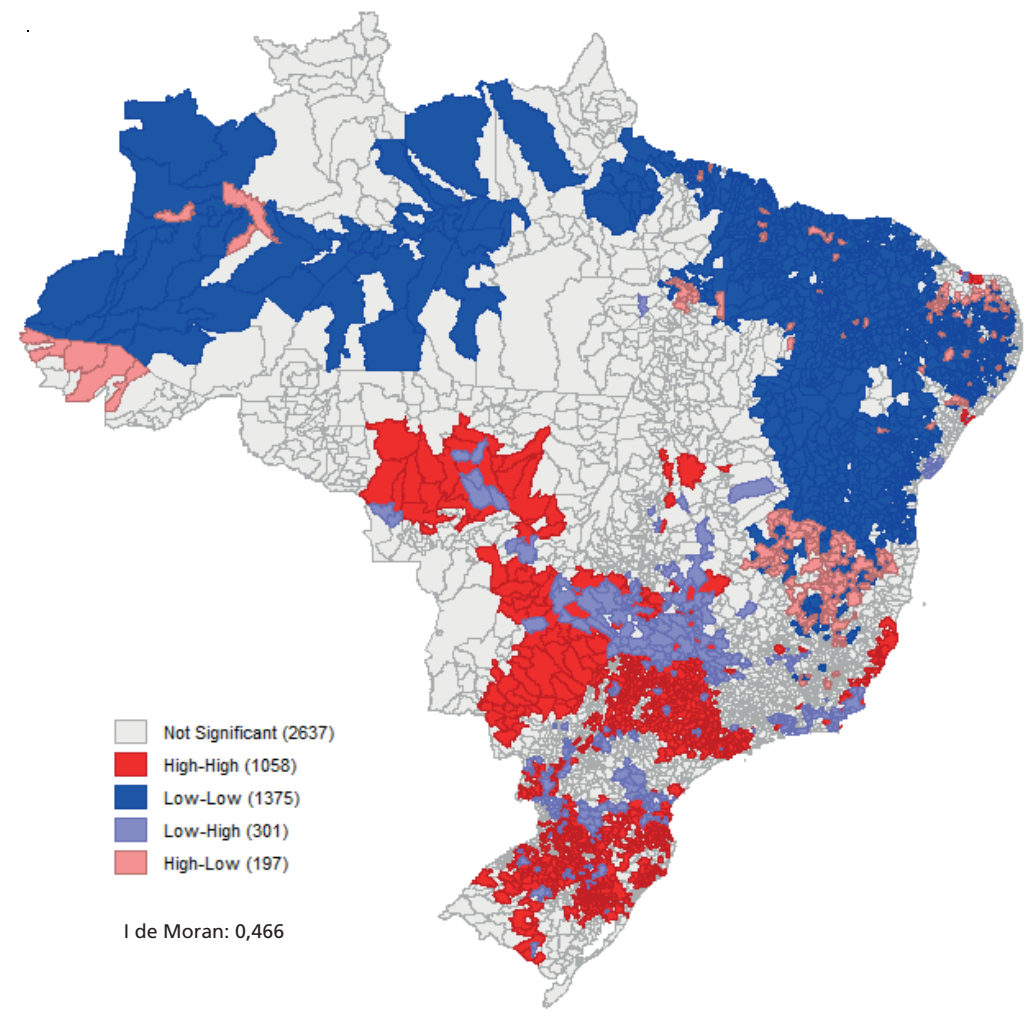

$3 B-2017$

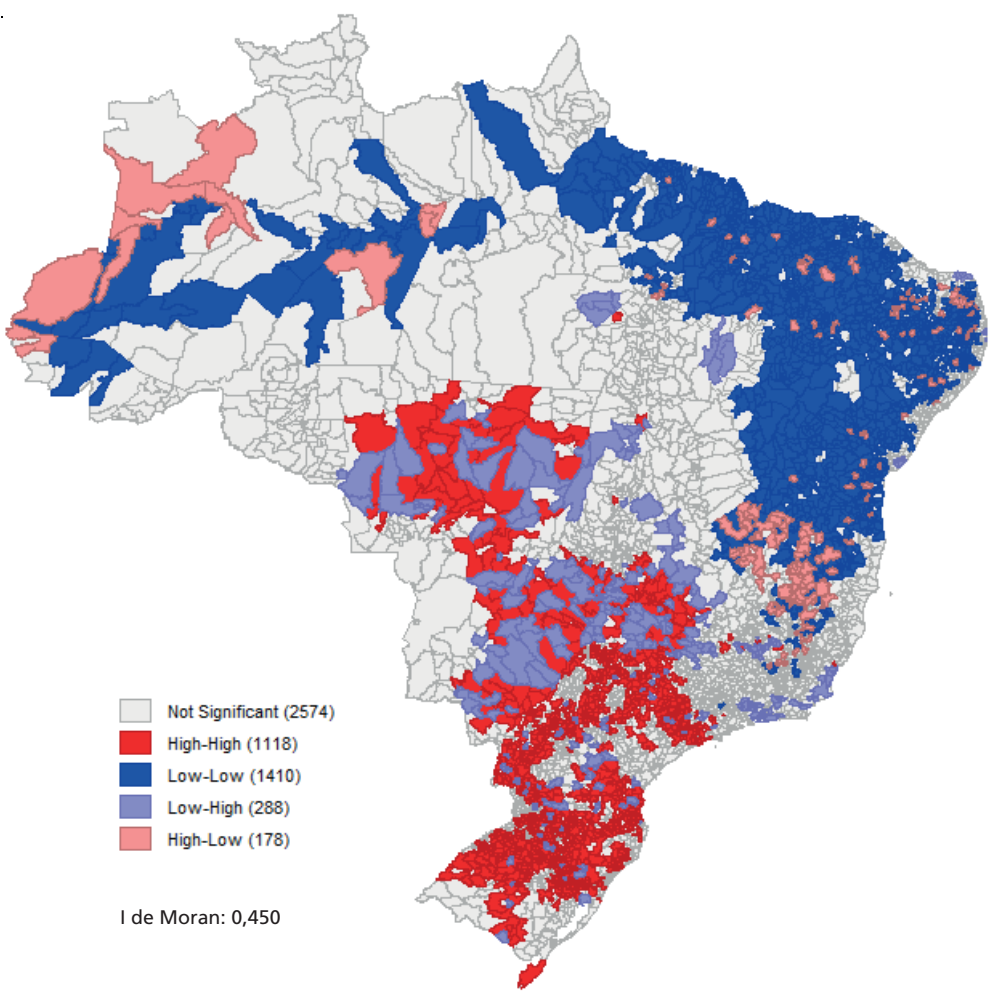

Fonte: STN, Inep e IBGE.

Obs.: Figura cujos leiaute e textos não puderam ser padronizados e revisados em virtude das condições técnicas dos originais (nota do Editorial). 
O indicador I de Moran foi 0,47 em 2007 e 0,45 em 2017 e, novamente, a maior parte dos clusters identificados foi do tipo alto-alto nos estados do Sul e Sudeste e do tipo baixo-baixo no Norte e Nordeste, o que é um indicativo de que os recursos do Fundeb se concentraram nas regiôes mais ricas do território nacional.

Esse resultado está de acordo com a lógica de distribuição de recursos do Fundeb, que, atualmente, se dá entre os municípios do mesmo estado e, dessa forma, estados mais ricos disponibilizam mais recursos para o fundo.

\section{CONCLUSÃO}

O Fundeb, instituído em 2007 com vigência até 31 de dezembro de 2020, tem como principais objetivos garantir um investimento mínimo por aluno e também promover a distribuição dos recursos em todo o território nacional. Passados mais de dez anos da implementação da política, na proximidade do término da vigência do fundo tal como foi desenhado, foi importante analisar a necessidade ou náo de aprimoramentos dos mecanismos de gestáo e alocaçáo para uma possível continuidade. Diante disso, este texto fez uma breve análise da distribuição do Fundeb por aluno, comparando com o PIB per capita dos municípios brasileiros em 2007 e 2017.

Os resultados evidenciaram que os recursos do Fundeb se concentraram nas regióes mais ricas do território nacional, o que provavelmente decorreu da lógica de distribuição do fundo que se dava entre os municípios do mesmo estado. Assim, aqueles com maior arrecadação disponibilizavam mais recursos para a conta estadual do Fundeb. Além disso, a complementação de recursos da União para os fundos que ficaram com o menor valor por aluno era feita no nível estadual e, dessa forma, municípios pobres em estados com elevado valor do fundo náo recebiam a complementação. Por sua vez, municípios ricos em estados que recebiam tal complementação também eram beneficiados. Vale ressaltar que outras fontes de arrecadação municipal para o financiamento da educação ${ }^{6}$ não eram levadas em consideraçáo na distribuição dos recursos para os municípios no mesmo estado, de modo que todos os municípios recebiam o mesmo valor por aluno.

Assim, considerar tais recursos disponíveis para investimentos em educaçáo nas contas municipais e realizar a complementação da União em nível local e por redes de ensino podem ser formas de melhorar o mecanismo de distribuição dos recursos Fundeb. Diante disso, o Decreto no 10.656, de 22 de março de 2021, tornou o fundo permanente, e foi adotado um modelo híbrido de distribuição dos recursos, no qual municípios pobres em estados ricos também passam a receber o complemento da União, sempre que o valor anual total por aluno não atingir o mínimo nacional.

\section{REFERÊNCIAS}

ALMEIDA, E. Econometria espacial aplicada. Campinas: Editora Alínea, 2012.

GONÇALVES, F. de O.; FRANÇA, M. T. A. Eficiência na provisão de educação pública municipal: uma análise em três estágios dos municípios brasileiros. Estudos Econômicos, v. 43, n. 2, p. 271-299, 2013.

SOUSA, M. C. S.; CRIBARI-NETO, F.; STOSIC, B. D. Explaining DEA technical efficiency scores in an outlier corrected environment: the case of public services in Brazilian municipalities. Brazilian Review of Econometrics, v. 25, n. 2, p. 289-315, 2005.

6. 0 art. 212 da Constituição Federal de 1988 determina que os estados e municípios devem destinar pelo menos 25\% de sua receita orçamentária para a manutenção e o desenvolvimento do sistema público de educação básica. Assim, em uma conta municipal específica para educação deve-se destinar, no mínimo, 5\% do valor arrecadado com os oito tributos que compõem o Fundeb, e $25 \%$ dos demais, conforme descrito na seção 2 deste texto. 



\title{
UM OLHAR TERRITORIAL PARA O MERCADO DE TRABALHO NO BRASIL (2002-2018) $)^{1,2}$
}

\author{
Fernando Cézar de Macedo 3
}

Leonardo Rodrigues Porto ${ }^{4}$

\section{APRESENTAÇÃO}

O mercado de trabalho no Brasil reverteu, no início do século XXI, a tendência de baixo desempenho da década de 1990. O crescimento econômico, puxado pelo aumento da demanda internacional de commodities e a elevação de seus preços, até a crise mundial de 2007 e as políticas anticíclicas praticadas pós-2008 mantiveram o crescimento da economia brasileira e a continuaçáo do aquecimento do mercado de trabalho. Este se beneficiou, também, de açóes explícitas de estímulo à demanda agregada promovidas pelo governo federal em decorrência das condiçôes macroeconômicas mais favoráveis na primeira década deste século, em comparação aos anos 1990. Mesmo após a deflagração da crise mundial, continuaria crescendo, ainda que em ritmo menor. A partir de 2014, no entanto, observa-se reversão desse quadro.

A melhora do mercado de trabalho até 2014 deu-se em consonância com a ampliação do crédito às famílias e com elevação do consumo, principalmente, nas regiōes Norte, Nordeste e Centro-Oeste do país, em decorrência do crescimento mais elevado da renda regional vis-à-vis ao do Sul e Sudeste. ${ }^{5}$

Os investimentos públicos tiveram importância macroeconômica por elevarem a formação bruta de capital fixo (FBCF), mas, também, regional, pois as participaçóes das regióes Norte, Nordeste e Centro-Oeste na carteira de investimentos do Programa de

1. DOI: http://dx.doi.org/10.38116/brua24art3

2. Este texto é um resumo do trabalho desenvolvido para o Projeto Diagnóstico da Situação Recente da Questão Regional Brasileira, coordenado pela Diretoria de Estudos e Políticas Regionais, Urbanas e Ambientais (Dirur) do Ipea no âmbito do Acordo de Cooperação Técnica (ACT)/Ipea/Ministério do Desenvolvimento Regional (MDR) patrocinado pela Secretaria Nacional de Desenvolvimento Regional e Urbano do MDR.

3. Pesquisador do Programa de Pesquisa para o Desenvolvimento Nacional (PNPD) na Dirur/lpea; professor do Instituto de Economia da Universidade Estadual de Campinas (IE/Unicamp); pesquisador do Centros de Estudos do Desenvolvimento Econômico (CEDE).E-mail:<fcmacedo@unicamp.br>.

4. Mestre em Desenvolvimento Econômico pelo IE/Unicamp; doutorando pesquisador do CEDE.E-mail:<Inrdporto@gmail.com>. 5.0 rendimento médio por habitante, entre 2005 e 2014, cresceu nas regiões Norte, Nordeste e Centro-Oeste, respectivamente, $48,2 \%, 51,1 \%$ e $57,2 \%$, enquanto Sudeste $(+41,8 \%)$ e Sul $(+48,0 \%)$ ficaram abaixo. Entre 2014 e 2018 , a situação se inverte, com as três primeiras, apresentando perda de rendimento média mais acentuada que as demais: Norte $(-3,4 \%)$, Nordeste $(-7,7 \%)$, Sudeste $(-1,8 \%)$, Sul $(-1,5 \%)$ e Centro-Oeste $(-3,5 \%)$. 
Aceleração do Crescimento (PAC) superaram suas participaçóes no produto interno bruto (PIB) brasileiro, impactando mais favoravelmente o mercado de trabalho delas. Portanto, consumo e investimento contribuíram para a lenta, porém contínua, desconcentração regional do emprego e do PIB que se verifica neste século XXI. Entre 2002 e 2014, em pontos percentuais (p.p.), Norte (+0,6 p.p.), Nordeste ( $+0,8$ p.p.) e Centro-Oeste ( $+0,8$ p.p.) ganharam participação no PIB, assim como Sul (+0,2 p.p.), sendo Sudeste o único perdedor (-2,4 p.p.).

Essa desconcentração regional apresentou caráter positivo porque ocorreu em situação de crescimento econômico: de 3,4\% ao ano (a.a.) para o Brasil entre 2002 e 2014. Apesar de a desconcentração continuar entre 2014 e 2017 - com ganhos para Norte (+0,6 p.p.), Nordeste (+0,5 p.p.) e Centro-Oeste (+0,6 p.p.) - ela apresentou caráter espúrio, ou meramente estatístico, pois ocorreu em contexto de recessão (-1,9\% a.a.). Ou seja, as regióes que são prioritárias na política regional aumentaram sua participação por decrescerem menos que a média brasileira, especialmente o Sudeste, e não pelo desempenho econômico favorável.

Este texto analisa a dinâmica regional do mercado de trabalho formal no país entre 2002 e 2018, a partir do cenário esboçado. Ele considera dois momentos: o primeiro, até 2014, se caracterizou pelo crescimento econômico e elevação dos postos de trabalho; o segundo, entre 2015 e 2018 e que se prolonga até os dias de hoje, foi marcado por recessão e aumento do desemprego. No primeiro, a ampliação dos postos de trabalho, a queda do desemprego, o aumento da formalização e a ampliação do poder de compra da força de trabalho pelo crescimento real do salário mínimo repercutiram regionalmente de forma diferenciada, com ganhos para todas as regióes, porém maiores para o Norte, Nordeste e Centro-Oeste. Já no período 2015-2018, os efeitos recessivos sobre o mercado de trabalho foram generalizados, afetando todos os setores e em todas as regiôes. Registrou-se queda brusca do número de empregos formais, de modo que o processo de desconcentraçáo dos postos de trabalho resultou dos efeitos mais acentuados da crise nas áreas de maior adensamento econômico.

\section{COMPORTAMENTO GERAL DO MERCADO DE TRABALHO}

Um primeiro aspecto a se considerar é a queda da taxa de desocupação (ou de desemprego) entre os anos de 2001 (era de 9,4\%) e 2013 (6,2\%), embora a partir de 2014 (6,9\%) observe-se retomada de seu crescimento, que continuou em 2015 (9,6\%). Importante destacar que esse comportamento foi generalizado para todas as cinco macrorregióes, mas com especificidades. As maiores quedas nessas taxas ocorreram no Sudeste e no Sul, entre os anos de 2001 e 2013. O Nordeste apresentou redução do desemprego, mas em ritmo menor que o do país: até 2007, sua taxa de desemprego estava abaixo da média brasileira e, nos anos seguintes, ela fica acima da média nacional. Em 2004, ${ }^{6} 2013$ e 2015, as taxas de desocupação das regióes foram respectivamente: Norte $(6,9 \%, 7,3 \%$ e $8,8 \%)$, Nordeste $(9,0 \%, 7,9 \%$ e $10,1 \%)$, Sudeste $(10,5 \%, 6,6 \%$ e $10,8 \%)$, Sul $(5,7 \%, 4,0 \%$ e $6,9 \%)$ e Centro-Oeste $(8,1 \%, 5,8 \%$ e $7,7 \%)$. Apenas esta última, sustentada por sua economia de exportaçáo, apresentava taxa de desemprego menor em 2015 comparativamente a 2004.

A redução do desemprego foi acompanhada por uma melhoria na condição ocupacional. Segundo os dados da Pesquisa Nacional por Amostra Domiciliar (PNAD), a participação da força de trabalho com carteira assinada no Brasil passou de 29,3\% do total das pessoas com mais de dez anos ocupadas em 2002 para 39,8\% em 2013. Ao longo de todo esse

6. Considera-se 2004 (e não 2001) porque a partir dele incorpora-se o Norte rural. 
período, sua participaçáo foi crescente, porém, em 2014 (com 39,1\%) e em 2015 (38,6\%) observa-se seu declínio, reflexo da crise econômica.

Esse movimento foi generalizado para todo o país. As regióes Norte e Nordeste continuaram com a menor participação dos trabalhadores nessa categoria em suas estruturas ocupacionais. Na primeira, o peso dos trabalhadores com carteira assinada no total das ocupaçóes passou de 17,6\% em 2004 para 24,7\% em 2013. No Nordeste, esses números foram 16,4\% (ano de 2002) e 26,0\% (2013). Seus níveis estiveram bem abaixo das participaçóes do Sudeste (37,5\% e 48,4\%, respectivamente); Sul (33,0\% e 45,5\%) e Centro-Oeste (27,7\% e 41,0\%). Em todas elas, as participaçôes apresentaram quedas em 2014 e 2015, com exceçóes do Norte e Nordeste que ainda apresentaram ligeira ampliação em 2014.

A queda da participação dos trabalhadores sem remuneração no total foi significativa, sobretudo no Nordeste, que declinou de 13,4\%, em 2002, para 3,6\% em 2013. Ali, mais de dois milhóes de trabalhadores saíram da condição de não remunerados entre esses dois anos assinalados. Entretanto, esse movimento ocorreu generalizadamente em todas as regióes: no Norte passou de $11,5 \%$ para 5,7\%; no Sudeste de 3,3\% para 1,2\%; no Sul de 9,7\% para 3,2\%; e no Centro-Oeste de 4,6\% para 1,3\%. ${ }^{8}$ Apesar dessa evolução, as regióes Norte e Nordeste possuíam 55,4\% do total dos trabalhadores sem remuneração do país em 2013 (em 2004 esse valor era de 60,5\%).

No pós-2003, o emprego formal cresceu a taxas mais elevadas do que o crescimento da economia brasileira e do próprio ritmo de geração de empregos, medido pela evolução de pessoas ocupadas (POs). Isso ocorreu em todas as grandes regióes (tabela 1), o que foi a principal novidade no mercado de trabalho brasileiro. É nesse sentido que Baltar et al. (2010) e Baltar (2015) referem-se a um crescimento desproporcional do emprego formal, até 2014.

$\mathrm{O}$ aumento mais acelerado dos vínculos formais vis-à-vis o aumento da PO representou melhora na qualidade do emprego. Em parte, também responde pela elevação da participação da renda do trabalho na demanda agregada. Ademais, a maior formalizaçáo habilitou os trabalhadores a terem acesso mais fácil ao crédito e às linhas de financiamento do sistema bancário comercial. Isso ajuda a explicar por que no período o consumo teve crescimento maior nas regiōes Norte, Nordeste e Centro-Oeste.

TABELA 1

Taxas de crescimento médio anual do PIB, da PO e do emprego formal (2003-2014)

(Em \%)

\begin{tabular}{llcc}
\hline Região & PIB & PO & Emprego formal \\
\hline Norte & 4,8 & 5,5 & 6,7 \\
Nordeste & 4,1 & 1,3 & 5,4 \\
Sudeste & 3,5 & 1,9 & 4,4 \\
Sul & 3,0 & 1,3 & 4,5 \\
Centro-Oeste & 4,7 & 2,7 & 5,4 \\
\hline
\end{tabular}

Fonte: IBGE; PNAD; Sistema de Contas Nacionais do Instituto Brasileiro de Geografia e Estatística (SCN/IBGE); Ministério da Economia; Relação Anual de Informações Sociais (Rais).

É importante registrar que o estoque de PO no Brasil aumentou em 18,7 milhóes, entre 2003 e 2014, enquanto o emprego formal cresceu num total de pouco mais de

7. No Norte esses dados estão referenciados para 2004 e 2013.

8. Dados referentes a 2002 e 2013, menos para o Norte, que se referem a 2004 e 2013. 
20 milhões. Isso indica que o crescimento dos trabalhadores formais não derivou apenas do desempenho econômico, mas também pelas razôes apontadas por Krein e Manzano (2014): o aprimoramento do aparato regulatório; a consolidação das instituiçôes e do marco legal definido na Constituição de 1988; as novas perspectivas e programas das instituiçôes públicas na área do trabalho; políticas de incentivo à formalização e simplificação promovidas pelo Estado; e ampliaçáo do poder de barganha dos sindicatos e trabalhadores.

Em termos regionais, Sul e Nordeste apresentaram maior relação entre empregos formais gerados e novas POs. A regiáo Sul ampliou o número de POs em 2 milhóes, enquanto o número de registros Rais cresceu em 3,3 milhôes. Já para o Nordeste, os números foram de 3,3 milhóes e 4 milhóes, respectivamente. Por sua vez, a região Sudeste teve crescimento de 7,8 milhóes (PO) e 9,4 milhóes (vínculos ativos) e o Centro-Oeste teve crescimento aproximado das duas cifras, sendo 2 milhôes de PO e 1,9 milhão de empregos registrados na Rais. Apenas a regiáo Norte teve crescimento absoluto de empregos Rais (1,4 milhão de novos vínculos) em ritmo menor do que o crescimento da $\mathrm{PO}$ (3,5 milhóes). ${ }^{9}$ Essa maior formalização apresentou características espaciais desconcentradoras, como se verá a seguir.

\section{DO CRESCIMENTO ACELERADO À RETRAÇÃO DO MERCADO DE TRABALHO}

O período subsequente, de 2015 a 2018, inaugura nova fase, ainda em processo, no qual se verifica forte reversão do quadro anterior, com queda dos indicadores de emprego formal, sem que ainda se tenha apontado indícios de retomada. Inclusive, a situação se agravou com a pandemia da Covid-19 em 2020.

Verificou-se queda brusca do número de empregos formais em 2015 e 2016 no Brasil, levando as cifras para os níveis do início da década. Em 2017 e 2018, o mercado de trabalho formal estabilizou-se, sem quedas abruptas, mas sem retomar os padróes anteriores. Em 2018, o estoque de empregos formais no país era de 46,6 milhóes de vínculos ativos, algo 5,9\% menor do que era em 2014. A queda chegou a ser de $-7,1 \%$, em 2016, equivalente a uma perda de 3,5 milhóes de empregos formais, entre 2014 e 2016, após dois anos de aumento expressivo das demissóes e de elevaçáo do desemprego no país.

Em termos regionais, Norte, Nordeste e Centro-Oeste apresentaram maior expansão de empregos formais no período 2002-2014, contribuindo para maior desconcentração. Após 2015, essa relaçáo começa a se alterar, conforme os diferentes impactos da crise econômica entre as regiōes. A regiáo Norte, que havia apresentado o maior ritmo de expansão no período 2002-2014, reduziu seu estoque de empregos formais em -4,8\%, entre 2014 e 2018, ou seja, uma perda de 134 mil postos de trabalho. O Nordeste, por sua vez, teve perda acumulada de 485 mil postos de trabalho, nesse mesmo período, uma redução de $-5,3 \%$ dos vínculos ativos. Essa perda chegou a ser de $-7,6 \%$ em 2016, em relação a 2014 . Ou seja, a região sofreu os efeitos imediatos da crise econômica sobre o mercado de trabalho de maneira mais intensa que a média do país, num primeiro momento (2015-2016), mas se recuperando nos anos subsequentes (2017-2018), ficando com o resultado relativo acumulado mais favorável do que o Brasil.

A região Centro-Oeste apresentou maiores oscilaçóes no período 2015-2018. Em relação a 2014, que foi o ápice do crescimento dos empregos formais, a região perdeu $115 \mathrm{mil}$ postos de trabalho, sendo a menor redução do país até 2018, em termos relativos (-2,7\%).

9. Em termos relativos, o ritmo de crescimento do emprego formal da região Norte ocorreu de forma mais acelerada que 0 de sua população ocupada, conforme demonstrado na tabela 1. 
Isso significa que os impactos da crise sobre o mercado de trabalho foram menores ali. A região foi a única que voltou a apresentar redução de seus postos de trabalho em 2018, após crescimento em 2017. O dado reflete, também, a dinâmica econômica dessa região, vinculada aos movimentos da demanda internacional de commodities.

As regiôes Sul e Sudeste apresentaram os menores ritmos de expansão da geração de empregos formais, entre 2002 e 2014, com a segunda apresentando as menores taxas de crescimento. Já no período subsequente (2015-2018), foi a regiáo Sudeste que apresentou o pior desempenho relativo entre as cinco macrorregióes brasileiras. Após 2014, a região perdeu 1,9 milhão de postos de trabalho, uma queda relativa de $-7,6 \%$. De igual modo, no subperíodo 2017-2018, o Sudeste foi a regiáo com a pior capacidade de recuperação, cuja retomada foi de apenas 0,2 p.p. dos empregos perdidos em 2015-2016.

A regiâo Sul teve perda acumulada de 325 mil vínculos ativos nesse período de crise, ou sejam uma queda de $-3,8 \%$. No entanto, seu desempenho só não é mais favorável do que o verificado na regiáo Centro-Oeste. O principal destaque é o do subperíodo 2017-2018, quando a regiáo recuperou boa parte dos empregos perdidos no subperíodo 2015-2016.

A tabela 2 apresenta as taxas de crescimento do emprego formal no Brasil e suas regióes, assim como sua distribuição regional e nos diferentes períodos analisados. Entre 2002-2018, o país elevou o número de postos de trabalho formais a uma taxa média anual de crescimento de 3,1\%. No período 2002-2014, esse crescimento havia sido de 4,7\% a.a., enquanto no período subsequente (2015-2018), a queda foi de 1,0\% a.a.

TABELA 2

Taxas médias de crescimento anual do número de empregos formais e participação relativa (2002-2018) (Em \%)

\begin{tabular}{|c|c|c|c|c|c|c|}
\hline \multirow{2}{*}{ Níveis territoriais } & \multicolumn{3}{|c|}{ Taxas médias anuais de crescimento } & \multicolumn{3}{|c|}{ Participação relativa } \\
\hline & $2002-2018$ & $2002-2014$ & $2015-2018$ & 2002 & 2014 & 2018 \\
\hline Brasil & 3,1 & 4,7 & $-1,0$ & 100,0 & 100,0 & 100,0 \\
\hline Centro-Oeste & 3,7 & 5,3 & $-0,3$ & 8,1 & 8,7 & 9,0 \\
\hline Nordeste & 3,7 & 5,4 & $-1,0$ & 16,9 & 18,4 & 18,5 \\
\hline Norte & 4,6 & 6,6 & $-0,7$ & 4,5 & 5,7 & 5,7 \\
\hline Sudeste & 2,6 & 4,2 & $-1,4$ & 52,7 & 50,0 & 49,1 \\
\hline Sul & 3,1 & 4,4 & $-0,4$ & 17,7 & 17,2 & 17,6 \\
\hline
\end{tabular}

Fonte: Rais/Ministério da Economia.

Entre as macrorregióes brasileiras, verificou-se o aumento da participação relativa das regióes Norte, Nordeste e Centro-Oeste. O Norte elevou sua participação na distribuição dos empregos formais do país em 1,2 p.p., no período 2002-2018, passando de 4,5\% do total do país, em 2002, para 5,7\%, em 2018. No período 2015-2018, a regiáo apresentou perdas a um ritmo de $0,7 \%$ a.a., de modo que manteve a sua participação no total do país, em relação a 2014 (era de 5,7\%).

O Nordeste passou de 16,9\% do total de vínculos ativos formais do país, em 2002, para 18,4\%, em 2014 (auge do crescimento), e 18,5\% em 2018, na crise. Esse resultado reflete as quedas mais acentuadas apresentadas pela região Sudeste, verificadas no período. Com efeito, o Nordeste apresentou perdas de empregos formais a uma taxa de 1,0\% a.a., similar ao Brasil. Entre as regiōes, foi o segundo pior desempenho, ficando atrás apenas do Sudeste (queda de $1,4 \%$ a.a.), na qual os efeitos da crise foram mais significativos. 
O Centro-Oeste, por seu turno, continuou elevando sua participação no total nacional de empregos formais, mesmo após a crise. Ao todo, a região elevou sua participação em 0,9 p.p. entre 2002 e 2018, passando de 8,1\%, em 2002, para 8,7\%, em 2014, e 9,0\% em 2018. $\mathrm{Na}$ crise, a regiáo foi a menos afetada, com queda de 0,3\% a.a. entre 2015 e 2018.

O Sudeste apresentou desempenho relativo ainda mais sofrível. Perdeu posição no período de maior crescimento da economia (2002-2014) e continuou perdendo com a deflagraçáo da crise (2015-2018). Seu estoque de empregos formais passou de 52,7\% do total do país, em 2002, para 49,1\%, em 2018, quando era de 50,0\%, em 2014. Essa perda de 3,6 p.p. expressa a continuidade do processo de desconcentração dos empregos no país, motivada por fatores diferentes. $\mathrm{Na}$ fase de crescimento, apresentou as mais baixas taxas de expansão do emprego ( $4,2 \%$ a.a.) e, com a crise, verificaram-se as maiores quedas, em um ritmo negativo de $1,4 \%$ a.a.

Por sua vez, a região Sul voltou a recuperar participação relativa com a crise. Essa região, entre 2002 e 2014, passou de $17,7 \%$ do estoque de empregos formais do Brasil para $17,2 \%$, resultado da segunda menor taxa de expansão do período ( $4,4 \%$ a.a.). No período 2015-2018, porém, voltou a recuperar participação com $17,6 \%$ do total de vínculos ativos, em 2018. Esse resultado decorreu de um ritmo de perdas menor do que em outras regióes $(-0,4 \%$ a.a. $)$, ficando atrás apenas do Centro-Oeste.

Em termos setoriais, verificaram-se mudanças importantes na estrutura do emprego formal e sua distribuição entre as regióes. Entre 2002 e 2018, as regiōes Norte, Nordeste e Centro-Oeste ganharam participação relativa em todos os cinco grandes setores analisados. A única exceção é a perda de participação de 0,6 p.p. do Nordeste no setor agropecuário, em relação ao total dos empregos no setor, nesse período.

A região Norte se destacou positivamente com a melhora de sua participação no número de empregos formais da agropecuária, passando de 2,8\% do total de vínculos ativos nesse setor, em 2002, para 6,6\% em 2018 (elevação de 3,8 p.p.). Esse desempenho refletiu a expansão do agronegócio exportador na região que apresenta maiores índices de formalização do trabalho, em decorrência do perfil das empresas que operam no setor. Em relação a 2014, o Norte perdeu participação relativa no setor da construção civil, com queda de 1,2 p.p. nesses quatro anos, sendo o setor mais afetado na regiáo, com a crise pós-2015.

O Nordeste foi a regiấo que mais ampliou participação do emprego formal no setor de comércio (+ 2,5 p.p.) e de serviços (+ 1,6 p.p.) durante o período 2002-2018. Em relação ao comércio, passou de $14,8 \%$ do total do país, em 2002 , para $17,4 \%$, em 2014 , e $17,3 \%$, em 2018. Em serviços, as cifras foram de 18,8\%, 20,1\% e 20,4\%, respectivamente. O desempenho desses setores no Nordeste é resultado direto das políticas adotadas no período, que favoreceram a expansáo do consumo das famílias. Já durante a crise, o destaque negativo vai para a perda de participaçáo do setor da construçáo civil, com queda de 2,6 p.p. entre 2014 e 2018, repercutindo os impactos da retração de um setor tradicionalmente empregador.

A região Centro-Oeste tem destaque positivo com o aumento na participação do número de postos de trabalho da indústria (extrativa, transformação e serviços de utilidade pública) durante o período analisado. Entre 2002 e 2018, os ganhos foram de 1,9 p.p., chegando a representar 6,5\% dos empregos no setor em 2018, quando era de 4,6\%, em 2002. Em parte, esse desempenho é resultante do aumento de empregos relacionados à agroindústria. Tal se deu, também, com a expansão dos empregos formais vinculados à agropecuária da região, com ganho de 6,7 p.p. nesse período. Com efeito, a região passou a figurar com o maior 
número de postos de trabalho no setor, em 2018, superando o Nordeste e o Sul, que eram os maiores em 2002. Com a crise, a região continuou ganhando participação relativa em todos os setores analisados, destacando-se sobretudo a agropecuária.

O Sudeste perdeu participação no número de vínculos ativos em todos os cinco setores analisados, entre 2002 e 2018. A indústria perdeu participação de 3,5 p.p. nesse período; a queda na construção civil foi de 2,4 p.p.; o comércio, $-4,3$ p.p.; os serviços, -3,3 p.p.; e a agropecuária representou uma queda de 8,5 p.p., em muito influenciado pelas mudanças produtivas no cultivo da cana-de-açúcar, cada vez menos demandante de mão de obra. A regiâo continuou perdendo participação setorial dos empregos pós-2015, com o advento da crise. No entanto, houve ganhos de participação da construção civil, que recuperou 1,4 p.p. dos empregos formais, entre 2014 e 2018.

Por fim, a região Sul se destaca pela perda de participação dos empregos formais do setor agropecuário, durante todo o período analisado. Já entre os anos de 2014 e 2018, verificaram-se ganhos importantes junto à indústria (aumento de 1,0 p.p.) e à construçáo civil, com aumento de 1,9 p.p., passando de 14,2\% dos empregos, em 2014, para 16,1\%, em 2018.

Em termos gerais, é possível dizer que o período de maior crescimento econômico (2002-2014) promoveu mais amplas transformaçôes na estrutura setorial dos empregos formais entre as regiôes brasileiras. Com a crise econômica, os efeitos recessivos sobre o mercado de trabalho foram generalizados, afetando mais ou menos todos os setores por igual, em todas as regiôes. A principal exceção é o caso da construção civil, bastante afetada com a crise, levando a maior redistribuiçáo do número de postos de trabalho entre as regiôes, inclusive com a reconcentração no Sudeste.

A análise se complementa com um breve panorama do que aconteceu com o emprego formal no âmbito das microrregióes (MRGs), nesse período recente de cenário de crise econômica. Considera-se, aqui, a tipologia sub-regional da PNDR aplicada às MRGs, conforme os parâmetros atualizados por Macedo e Porto (2018). O desempenho das MRGs segundo a sua tipologia regional pode ser observado na tabela 3, para todo o período analisado (2002-2018).

\section{TABELA 3}

Taxas médias de crescimento anual do número de empregos formais e participação relativa, segundo a tipologia sub-regional da PNDR (2002-2018)

(Em \%)

\begin{tabular}{lcccccccc}
\hline \multirow{2}{*}{ Tipologia da PNDR } & \multicolumn{3}{c}{ Taxas médias anuais de crescimento } & & \multicolumn{3}{c}{ Participação relativa } \\
\cline { 2 - 3 } \cline { 7 - 8 } & $2002-2018$ & $2002-2014$ & $2015-2018$ & & 2002 & & 2014 & 2018 \\
\hline Alta renda & 2,8 & 4,4 & $-1,3$ & & 78,2 & 76,1 & 75,1 \\
Baixa renda & 4,3 & 5,6 & 0,6 & & 2,8 & 3,1 & 3,3 \\
Dinâmica & 4,4 & 6,1 & $-0,4$ & & 6,0 & 7,0 & 7,2 \\
Estagnada & 3,7 & 5,1 & $-0,3$ & & 13,1 & 13,8 & 14,3 \\
\hline
\end{tabular}

Fonte: RAIS/Ministério da Economia.

Em 2018, as MRGs de alta renda concentravam 75\% dos empregos formais do país, sendo a única que perdeu participação relativa durante o período analisado. Esse grupo apresentou a menor taxa de crescimento dos postos de trabalho, em todo o período, com ritmo menos acelerado na fase de maior crescimento - 4,4\% a.a. entre 2002 e 2014 - e com a maior queda no período da crise, cuja redução foi de -1,3\% a.a., entre 2015 e 2018. 
Em 2018, as MRGs de alta renda respondiam por 35 milhóes dos vínculos ativos de emprego formal do país.

As MRGs de baixa renda, que foram alvos prioritários de políticas públicas, elevaram a sua participação no número de empregos formais em 0,6 p.p., entre 2002 e 2018, sendo que 0,3 p.p. foram obtidos no período da crise econômica. Esse foi o único grupo a apresentar crescimento positivo, entre 2015 e 2018. Cresceu à taxa de 0,6\% a.a., nesse período, tendo apresentado cifra negativa apenas em 2016, quando perdeu mais de 90 mil postos de trabalho, em relação a 2015. Nos demais anos, as cifras foram de: aumento de apenas 284 postos de trabalho, em 2015; crescimento de 85 mil, em 2017; e 36 mil, em 2018. Nesse último ano, seu estoque de empregos formais foi de 1,5 milhão de vínculos ativos.

No caso das MRGs dinâmicas, houve redução do número de vínculos ativos formais, entre 2015 e 2018, a uma taxa de $-0,4 \%$ a.a. Foi um dos piores resultados entre os quatro grupos, demonstrando freio justamente nas áreas que lideravam o crescimento no período anterior. Entre 2002 e 2014, as MRGs dinâmicas cresceram à taxa de 6,1\% a.a., o que elevou a sua participação relativa no total do país, passando de 6,0\%, em 2002, para 7,0\%, em 2014, e 7,2\%, em 2018. Esse ganho de participaçáo em 2018 decorre, sobretudo, do péssimo desempenho das MRGs de alta renda.

As MRGs estagnadas, por sua vez, apresentaram crescimento de 5,1\% a.a. entre $2002 \mathrm{e}$ 2014, e queda de -0,3\% a.a., no período subsequente (2015-2018). Com isso, elevou a sua participação no total de empregos formais do país, durante o período analisado. Em 2002, respondia por 13,1\% dos postos de trabalho, passando para 14,3\%, em 2018.

O desempenho desses quatro grupos reforça o padrão verificado em outros níveis territoriais de observaçáo para esse período recente. Qual seja, no período 2015-2018, o processo de desconcentração dos postos de trabalho decorreu, sobretudo, dos impactos da crise econômica sobre as áreas de maior adensamento econômico do país. Assim, há um processo diferenciado em relação ao período anterior, quando a redistribuição dos vínculos ativos acompanhava o processo de desconcentração econômica regional promovida pelo bom desempenho das regiôes Norte, Nordeste e Centro-Oeste.

\section{CONSIDERAÇÕES FINAIS}

O texto realizou uma análise da evolução regional do emprego formal no país, tomando como referenciais os períodos 2002-2014 e 2015-2018. Verificou-se uma fase positiva de expansão do mercado de trabalho formal no Brasil, no período 2002-2014, com o emprego crescendo a taxas mais elevadas que o crescimento da economia brasileira, tendo sido um fenômeno comum a todas as regiôes. Após 2014, o mercado de trabalho brasileiro apresentou forte reversão, em relação ao período anterior. Entre os anos de 2015 e 2018, verificou-se a queda dos indicadores do emprego formal, em decorrência da grave crise econômica e política no país, sem que ainda exista indícios de retomada.

Em relação aos quatro grupos sub-regionais definidos pela PNDR, seu desempenho reforça o padrão verificado também em outras escalas de análise, durante esse período mais recente. Entre 2015 e 2018, o processo de desconcentração dos postos de trabalho decorreu, sobretudo, dos impactos da crise econômica sobre as áreas de maior adensamento econômico do país. Dessa maneira, o texto evidenciou como os mercados de trabalho regionais puderam reagir aos ciclos econômicos recentes. 


\section{REFERÊNCIAS}

BALTAR, P. Crescimento da economia e mercado de trabalho no Brasil. Rio de Janeiro: Ipea, 2015. (Texto para Discussão, n. 2036).

BALTAR, P. E. A. et al. Trabalho no governo Lula: uma reflexão sobre a recente experiência brasileira. Global Labour University, n. 9, May 2010.

KREIN, J. D.; MANZANO, M. P. Notas sobre a formalizaçáa: estudo de caso Brasil. Brasília: OIT, 2014. Disponível em: <http:/www.ilo.org/wcmsp5/groups/public/---americas/---ro-lima/ documents/publication/wcms_245624.pdf>. Acesso em: 10 jul. 2017.

MACEDO, F. C.; PORTO, L. R. Proposta de atualizaçáo das tipologias da PNDR: nota metodológica e mapas de referência. Brasília: Ipea, 2018. (Texto para Discussão, n. 2414). 



\title{
O FECHAMENTO DAS FRONTEIRAS TERRESTRES AMAZÔNICAS E IMPACTOS NA MOBILIDADE TRANSNACIONAL ${ }^{1,2}$
}

\author{
Maria Nunes ${ }^{3}$
}

\section{INTRODUÇÃO}

Em decorrência da propagação geográfica do novo coronavírus, a maioria dos países adotou várias medidas sanitárias com o objetivo de restringir a circulação de pessoas e a propagação da doença. No subcontinente sul-americano, todos os países fecharam suas fronteiras terrestres nas semanas subsequentes à declaração da Organização Mundial da Saúde (OMS), em 11 de março de 2020, classificando a Covid-19 como pandemia.

Pactuado pela OMS que a Covid-19 tratava-se de uma emergência sanitária mundial, várias medidas de contenção da propagaçâo do vírus foram tomadas para restringir a mobilidade humana: distanciamento social, quarentenas, fechamento das fronteiras internacionais, entre outras. Entretanto, cada país adotou tais medidas acordadas aos interesses nacionais.

Isso ocorreu também com os países da região sul-americana, que adotaram medidas e estágios diferentes para questôes comuns à região. Exemplos que esclarecem essa situação são o fechamento das fronteiras terrestres, que ocorreu em diferentes períodos, e a imposiçáo de um conjunto variado de restriçóes à entrada e à circulaçáo de pessoas e bens nos respectivos territórios nacionais.

Com o fechamento das fronteiras internacionais - terrestre, fluvial e aérea -, a mobilidade transfronteiriça foi altamente impactada. Com o objetivo de limitar a entrada de estrangeiros não residentes, a medida teve grande efeito sobre a saída de imigrantes pelos corredores de passagem em pontos das fronteiras terrestres dos países amazônicos.

Este ensaio pretende resgatar, de forma incipiente, algumas consequências da falta de articulação dos países amazônicos no fechamento de suas fronteiras terrestres e na adoção das medidas de restrição da circulação e da mobilidade transfronteiriça, em função da emergência sanitária mundial instaurada.

1. DOI: http://dx.doi.org/10.38116/brua24art4

2. Este texto foi produzido no âmbito da pesquisa Fronteiras do Brasil: uma Avaliação de Política Pública, desenvolvida na Diretoria de Estudos e Políticas Regionais, Urbanas e Ambientais (Dirur) do Ipea.

3. Pesquisadora do Programa de Pesquisa para o Desenvolvimento Nacional (PNPD) na Dirur/lpea; e doutora em geografia. 
As informaçóes e os dados foram levantados principalmente por meio de matérias jornalísticas, documentos institucionais dos países fronteiriços e publicações de pesquisas acerca das temáticas fronteiriça e migratória, como MT Brasil: migraçôes transfronteiriças fortalecendo a capacidade do governo federal para gerenciar novos fluxos migratórios, desenvolvida pelo ICMPD (2016) e Migração e Refúgio no Brasil: a inserção de imigrantes, solicitantes de refúgio e refugiados no mercado de trabalho (Cavalcanti, Oliveira e Macedo, 2019), publicação do Ministério da Justiça e Segurança Pública (MJSP) - Relatório Anual 2019.5

\section{MEDIDAS DE CONTENÇÃO DA COVID-19 NAS FRONTEIRAS TERRESTRES AMAZÔNICAS}

Alguns pontos da fronteira norte brasileira se consolidaram como corredores de passagem para migração internacional. Na fronteira internacional de Roraima, via articulação fronteiriça Pacaraima/Brasil-Santa Elena do Uairén/Venezuela, registrou-se intensa entrada de imigrantes venezuelanos nos últimos anos. Após entrarem no Brasil, os venezuelanos se concentram no norte do país, formando um cinturão de ocupação nos centros urbanos de Pacaraima-Boa Vista/Roraima e Manaus/Amazonas, cujo eixo de articulação se dá via BR-174.

Por sua vez, a conurbação fronteiriça Assis Brasil-Iñapari-Bolpebra (Assis Brasil, no Acre/Brasil, Ińapari, no departamento de Madre de Dios/Peru e Bolpebra, no departamento de Pando/Bolívia) constitui o principal portal de entrada e saída das correntes migratórias haitiana e africana, cujo roteiro migratório mescla transportes aéreo e rodoviário, o qual é utilizado para alcançar a fronteira brasileira, que, em virtude da posição geográfica e da ineficiente fiscalizaçáo na fronteira peruana, possibilita a entrada de imigrantes no território brasileiro via Ińapari, município peruano fronteiriço. A partir de 2017, a migração haitiana tem desacelerado nesse ponto de fronteira, permanecendo com mais dinamismo a entrada de senegaleses, venezuelanos, angolanos, congoleses, dominicanos, entre outros.

Na fronteira internacional acreana, além de Assis Brasil, o centro urbano de Brasiléia sofre com adensamento de contingentes de pessoas migrantes que chegam em situação de vulnerabilidade, mas em razão da fiscalização mais rigorosa nas fronteiras bolivianas, a entrada de fluxos migratórios internacionais por essa conurbação - Epitaciolândia-Brasiléia/Brasil-Cobija/Bolívia, via departamento de Pando, na Bolívia - é inexistente, porém, em razão de ofertar serviços migratórios, Brasiléia recepciona pessoas em situação de mobilidade transnacional.

Atualmente, Pacaraima e Boa Vista, em Roraima, têm sofrido com a permanência desordenada e consistente de imigrantes venezuelanos em suas áreas urbanas, cujas deficiências na oferta de serviços públicos ficaram mais evidentes com a Covid-19. A relação entre a proliferação da doença e o esgotamento dos serviços de saúde pública com a entrada de venezuelanos em Roraima levou o Brasil a decidir fechar sua fronteira antes de tal medida ser tomada nas demais fronteiras da região Norte.

Em decorrência da entrada e da circulação de pessoas e mercadorias de outras regiōes do mundo, os pontos de fronteiras são sempre sensíveis no contexto de transmissibilidade de enfermidades infectocontagiosas em humanos e de sanidade animal e fitossanitária. As cidades

4. Disponível em: <https://www.justica.gov.br/sua-protecao/trafico-de-pessoas/publicacoes/anexos-pesquisas/mtbrasil_act1-3-1-4_relatorio_final.pdf>.Acesso em: 17 jun. 2020.

5. Disponível em: <https://portaldeimigracao.mj.gov.br/images/relatorio-anual/RELAT\%C3\%93RI0\%20ANUAL\%20 OBMigra\%202019.pdf>. Acesso em: 10 jul. 2020. 
acreanas fronteiriças, em decorrência da entrada de imigrantes africanos, já demonstravam preocupação com a entrada do vírus Ebola antes mesmo da pandemia da Covid-19.

Sem exceção, à época da pesquisa de campo, todos expressaram receio de que os migrantes pudessem infectar os munícipes, sendo a doença proliferada com rapidez, em razão do frágil sistema de saúde e das precárias condiçôes sanitárias e de higiene. O medo do vírus ebola chegou a instalar nas cidades acreanas o preconceito e a discriminação aos migrantes africanos (ICMPD, 2016, p. 84).

Com a pandemia da Covid-19, a preocupação com a entrada de doenças infectocontagiosas nos territórios nacionais ganhou concretude. Assim, acordados aos interesses estratégicos, os países do subcontinente começaram impondo restriçôes à entrada e à circulação em seus territórios. Porém, ao adotarem diferentes estágios e normas na implementação dos conjuntos de medidas, levaram ao impedimento de grupos de migrantes que buscavam sair pelos mesmos pontos da fronteira terrestre que haviam entrado no Brasil.

Dentro do conjunto de medidas, os países fecharam suas fronteiras internacionais como meio de restringir a entrada de passageiros em seus territórios. As restriçóes recaíram, em um primeiro momento, sobre os passageiros oriundos de países que estavam com quadros epidêmicos de contaminação pela Covid-19, e, paulatinamente, foram sendo estendidas a todos os estrangeiros (quadro 1).

QUADRO 1

Primeiras medidas e normas à entrada e mobilidade nos países fronteiriços amazônicos

\begin{tabular}{|c|c|}
\hline Países & Legislação do fechamento das fronteiras e regramento para circulação nos países amazônicos fronteiriços \\
\hline Brasil ${ }^{1}$ & $\begin{array}{l}\text { - } 18 \text { de março: fechamento da fronteira terrestre com a Venezuela. }{ }^{2} \\
\text { - } 19 \text { de março: fechamento das fronteiras terrestres com Argentina, Peru, Bolívia, Colômbia, Guiana, Guiana } \\
\text { Francesa, Paraguai e Suriname. } \\
\text { - } 22 \text { de março: fechamento da fronteira terrestre com Uruguai. } \\
\text { - } 27 \text { de março: fechamento da fronteira aérea para estrangeiros. }\end{array}$ \\
\hline Bolívia ${ }^{3}$ & $\begin{array}{l}\text { - } 14 \text { de março: suspenção temporária (14 a 31/3) de voos diretos da Europa. } \\
\text { - } 17 \text { de março: fechamento gradual de todas as fronteiras para estrangeiros. } \\
\text { - } 18 \text { de março: proibição da entrada de passageiros oriundos do espaço Schengen, Reino Unido, Irlanda, Irã, } \\
\text { China e Coreia do Sul. } \\
\text { - } 20 \text { de março: fechamento de todas as fronteiras; estabelecimento de restrição à circulação da população por } \\
\text { meio da imposição de quarentena, suspensão de transportes rodoviários públicos e interurbanos. }\end{array}$ \\
\hline Colômbia ${ }^{4}$ & $\begin{array}{l}\text { - } 15 \text { de março: restrição à entrada de estrangeiros não residentes. } \\
\text { - } 17 \text { de março: fechamento de todas as fronteiras (cidadãos nacionais e estrangeiros). }\end{array}$ \\
\hline Guiana & - 31 de março: fechamento total das fronteiras. \\
\hline Guiana Francesa & $\begin{array}{l}\text { - } 17 \text { de março: fechamento da fronteira Schengen. } \\
\text { - } 15 \text { de março: fechamento da fronteira com Suriname e Brasil. }\end{array}$ \\
\hline Peru $^{5}$ & $\begin{array}{l}\text { - } 16 \text { de março: fechamento total das fronteiras; suspenção de meios de transporte internacional de passageiros e } \\
\text { restrição à entrada de estrangeiros não residentes. }\end{array}$ \\
\hline Suriname & $\begin{array}{l}\text { - } 14 \text { de março: fechamento de fronteiras à entrada de estrangeiros. } \\
\text { - } 15 \text { de março: fechamento completo das fronteiras internacionais. }\end{array}$ \\
\hline Venezuela ${ }^{6}$ & $\begin{array}{l}\text { - } 12 \text { de março: suspenção de voos da Colômbia e da Europa e fechamento das fronteiras marítimas e terrestres. } \\
\text { - } 17 \text { de março: decreto de quarentena social. }\end{array}$ \\
\hline
\end{tabular}

Fonte: Decretos e portarias emitidas pelos países relacionados no quadro e Pêgo et al. (2020, p. 31).

Elaboração da autora.

Notas: ${ }^{1}$ Segundo as portarias que disciplinaram o fechamento das fronteiras brasileiras, as medidas consideram as notas técnicas da Agência Nacional de Vigilância Sanitária (Anvisa).

2 Portaria no 120, de 17 de março de 2020; Portaria no 125, de 19 de março de 2020; Portaria no 132, de 22 de março de 2020; Portaria № 152, de 27 de março de 2020. Disponível em: <http://www.planalto.gov.br/CCIVIL_03/Portaria/quadro_portaria.htm>. Acesso em: 10 maio 2020.

${ }^{3}$ Decreto Supremo no 4.190; Decreto Supremo № 4.192; Decreto Supremo no 4.196. Disponível em: <http://www.gacetaoficialdebolivia.gob. bo/normas/buscar_comp/(COVID-19)/page:2>. Acesso em: 5 jun. 2020.

${ }^{4}$ Decreto no 417, de 17 de março de 2020. Disponível em: <http://www.regiones.gov.co/Inicio/assets/files/51.pdf>. Acesso em: 7 jun. 2020.

5 Decreto Supremo Presidencial no 044/2020-PCM do Peru. Disponível em: <https://busquedas.elperuano.pe/normaslegales/decreto-

supremo-que-declara-estado-de-emergencia-nacional-po-decreto-supremo-n-044-2020-pcm-1864948-2/>. Acesso em: 7 jun. 2020.

${ }^{6}$ Decreto no 4.166 . 
As restriçóes impostas à mobilidade transfronteiriça (quadro 1) com o fechamento das fronteiras terrestres impactaram a rigor a entrada de estrangeiros não residentes, mas atingiram também a circulação cotidiana da população fronteiriça, criando uma série de dificuldades à dinâmica interfronteiriça.

Parte das implicações do fechamento das fronteiras terrestres dos países da região deriva da desarticulação na adoção de medidas e regras sobre as zonas fronteiriças, cujos impactos são comuns aos dois territórios nacionais. No subcontinente, entre as medidas adotadas na tentativa de deter a circulação da Covid-19 estão o fechamento total da fronteira, a suspensão de transportes terrestres de passageiros, a quarentena total, a suspensão de repatriação, e as proibiçóes à entrada de estrangeiros e de não residentes. Ocorre que essas medidas náo foram uniformizadas entre os países fronteiriços, o que deixou milhares de pessoas que se encontravam em deslocamento temporariamente "desterritorializadas", em função da demora na expedição de autorizaçôes e outros embaraços em razáo da pandemia da Covid-19, retendo vários grupos de imigrantes nas áreas adjacentes do limite internacional, impactando pequenos municípios fronteiriços.

Sob a condição de emergência sanitária, todos os países da região adotaram medidas para impedir a circulação de imigrantes pelos seus territórios (quadro 1). Entretanto, alguns empregaram medidas de controle mais rígidas, que impediram também a entrada imediata de seus cidadãos, que se encontravam fora do país quando da declaração da condição de pandemia.

$\mathrm{Na}$ fronteira brasileira, logo no início do evento pandêmico, foram registradas várias ocorrências de imigrantes dos países vizinhos sul-americanos que ficaram retidos na linha de fronteira internacional por não conseguirem permissão para entrarem seus países pátrios, e que, ao realizarem os procedimentos de saída do Brasil, não podiam mais retornar porque a fronteira encontrava-se fechada à entrada de estrangeiros não residentes. Tal medida resultou na retenção de diversos grupos de sul-americanos em vários pontos do limite internacional: no recorte sul, foram retidos argentinos e paraguaios. Já no recorte central, ficaram retidos diversos grupos de bolivianos ao longo dos primeiros meses de pandemia e, na fronteira norte, especificamente na divisa acreana, ficaram retidos grandes grupos de imigrantes de nacionalidades variadas - haitianos, paquistaneses, senegaleses e angolanos -, inclusive peruanos e bolivianos, que cumpriam o período de quarentena exigida pelos seus países em território brasileiro.

No subcontinente, o Peru e a Bolívia compuseram o rol dos países que tomaram medidas sanitárias mais severas em razão da declaração de Emergência Nacional, ${ }^{6}$ que interferiu na circulação em seus territórios: fechamento total de suas fronteiras (medida temporária) ${ }^{7}$ e restrição à circulação de veículos públicos e privados (autorizados somente veículos de atendimento à saúde). $\mathrm{O}$ conjunto de medidas desses países acabou repercutindo em pontos da fronteira brasileira, a exemplo da retenção de grandes grupos de imigrantes no município acreano de Assis Brasil, inaugurando uma crise migratória no município.

Em face da crise sanitária de Covid-19, o Acre retoma papel importante como rota internacional de imigrantes, porém em sentido contrário ao movimento migratório de

6. Decreto Supremo Presidencial no 044/2020-PCM do Peru, que declara o Estado de Emergência Nacional no país e estabelece a proibição de ingresso de estrangeiros ao Peru, porém o fechamento total das fronteiras e a proibição de circulação de veículos e transportes terrestres impediam, temporariamente, a entrada de seus nacionais.

7. Disponível em: <http://www.gacetaoficialdebolivia.gob.bo/normas/buscar_comp/(COVID-19)/page:2>. Acesso em: 10 jun. 2020. 
haitianos da primeira metade da década de 2010 e de outras nacionalidades que continuaram entrando no Brasil por esse ponto da fronteira.

No início de 2020, com a pandemia de Covid-19, essas localidades são novamente tensionadas por um movimento de saída de imigrantes oriundos do Centro-Sul do Brasil, em movimento migratório de retorno, visando alcançar outros destinos como o México e os Estados Unidos. Entretanto, com o recrudescimento das medidas de emergência sanitária no Peru, com proibição da entrada de estrangeiros e da exigência de quarentena aos seus nacionais, avolumou-se ainda mais o contingente de imigrantes retidos em Assis Brasil, ampliando a crise migratória instaurada.

Apesar de muitos peruanos permanecerem na ponte binacional sobre o rio Acre - Ponte de Integração Brasil-Peru -, em barracas improvisadas, até poderem adentrar no território peruano, muitos chegavam em situaçáo de vulnerabilidade e alguns infectados pela Covid-19, o que ampliava ainda mais os riscos de contaminação e transmissão da doença na cidade, exigindo rápida assistência das autoridades brasileiras.

Diante das medidas sanitárias adotadas pelos vizinhos para contenção da circulação de pessoas em seus territórios e para evitar o agravamento da crise já instalada nos pequenos municípios acreanos fronteiriços, em razão dos contingentes de imigrantes retidos que se avolumavam nas áreas da fronteira brasileira, o Acre, por meio do Decreto no 5.496/2020, interrompeu a circulaçáo e o ingresso de veículos públicos e privados e de transporte coletivo interestadual e internacional de passageiros em seu território, salvo os que se destinariam ao transporte de pacientes. Assim, por meio da normativa, em maio e abril, o Acre evitou a entrada de alguns grupos de peruanos ${ }^{8}$ que ficariam retidos por dias no lado brasileiro da fronteira em razão das medidas sanitárias que se encontravam vigorando no Peru, o que ampliaria ainda mais as dificuldades já enfrentadas por outros grupos de imigrantes retidos no limite internacional.

Em razão da crise migratória e da exposição desse fluxo à doença, a administração pública precisou buscar estratégias para atendimento das necessidades básicas dessas pessoas, bem como para a prevenção e o controle de transmissão da doença na regiáo. Assim, o prefeito municipal, no uso de suas atribuiçôes legais, decretou situação de calamidade pública no feito de $\mathrm{n}^{\mathrm{o}} 044$, de 31 de março de 2020, publicado no Diário Oficial do Acre, ediçáo no 12.772, de 2 de abril de 2020. Entre as condiçôes relacionadas no decreto, como agilidade na aquisição e disponibilidade de insumos e serviços para atender às necessidades dos estrangeiros com alimentação e alojamento, foram acrescidas açôes para o enfrentamento à pandemia:

atual situaçáo vivida no município de Assis Brasil, que desde a data do dia 17 de março de 2020, passou a enfrentar de forma inesperada com o isolamento de 244 (duzentos e quarenta e quatro) estrangeiros, oriundos, sobretudo, de região de alto risco do vírus em comento, que, impedidos de ingressarem no Peru, por conta do fechamento da fronteira daquele país por ordem de sua autoridade maior, e sem terem para onde ir, resolveram permanecer na circunscrição do município (Acre, 2020, p. 41).

8. Disponível em: <https://agencia.ac.gov.br/acao-coordenada-pela-seguranca-impede-entrada-de-43-peruanos-em-soloacreano/>. Acesso em: 15 jun. 2020. 
Atenta-se ao fato de que as medidas de assistência emergencial ${ }^{9}$ para acolhimento às pessoas em situação de vulnerabilidade, decorrente de fluxo migratório provocado por crise humanitária, são pactuadas na Lei nº 13.684/2018.

Informaçóes da Prefeitura de Assis Brasil davam conta de que, nos primeiros meses da pandemia, de março a setembro de 2020, a permanência de imigrantes no município era dinâmica, pois havia constantes movimentos de saída e chegada de grupos.

No final de março, o município já recepcionava quase trezentos estrangeiros que se encontravam instalados em alojamentos improvisados, os quais, segundo gestores públicos, estavam no limite da capacidade de atendimento. Desse grupo, cerca de 180 eram haitianos, paquistaneses, senegaleses e angolanos oriundos do Sul e do Sudeste do Brasil que, nas últimas semanas de março de 2020, iniciaram o longo roteiro de retorno, via conurbação fronteiriça Assis Brasil/Acre-Ińapari/Peru-Bolpebra/Bolívia.

No final de maio eram por volta de 270 imigrantes que se encontravam no município. Como no final de março, a maioria era composta por haitianos, que somavam mais de 150 . $\mathrm{O}$ volume de imigrantes que estavam no município era alterado ao longo dos meses em razáo dos grupos de peruanos que entravam no Peru, após o período de quarentena. Também havia outras nacionalidades que buscavam estratégias para atravessar a fronteira por vias e meios não convencionais, pois, ao longo da pandemia, a Rodovia Interoceânica não serviu somente ao trânsito de cargas, mas também ao fluxo migratório que buscava atravessar esse ponto da fronteira.

A dinâmica migratória de retorno permaneceu ao longo dos meses, até a reabertura da fronteira do Peru, ocorrida somente no segundo semestre de 2020. Em situação de normalidade, a crise migratória em Assis Brasil já impactaria os recursos da administração pública municipal. Segundo informações da gestão do período, até a reabertura da fronteira do Peru, o município teria gastado mais de $\mathrm{R} \$ 1$ milhão com fornecimento de serviços aos imigrantes.

Desde as primeiras semanas da declaração de emergência sanitária, grupos de sul-americanos em deslocamentos ficaram retidos no lado da fronteira brasileira. Além da fronteira acreana, vários grupos de imigrantes ficaram retidos por dias em outros pontos da fronteira internacional brasileira, aguardando o período de quarentena forçada exigido pelos países de origem para a entrada, ou autorização e trâmites migratórios. Essa situaçáo continuou ocorrendo ao longo do avanço da pandemia.

O movimento de retorno de imigrantes no subcontinente pode ter sido ampliado em virtude do cenário provável de dificuldades econômicas que os países tendem a atravessar ao longo do evento pandêmico e em pós-pandemia, em razão da diminuição das atividades econômicas, de geração de emprego e renda.

\section{CONSIDERAÇÕES FINAIS}

Com a declaração de emergência sanitária mundial, os países iniciaram a adoção de medidas e regras de circulação de pessoas e mercadorias pelos seus territórios. Dentro do conjunto de medidas para a contenção do espalhamento da Covid-19, países e blocos regionais adotaram o fechamento de suas fronteiras internacionais - aéreas, fluviais e terrestres.

9. Questões específicas da crise migratória em Assis Brasil, que por vezes exigiu a intervenção de várias instituiç̧̃̃es, entre elas o Ministério Público Federal e a Defensoria Pública da União e entidades de direitos humanos. 
No atual estágio mundial, marcado pela rapidez na circulação de bens e pessoas, o fechamento das fronteiras terrestres aparece como mais uma estratégia na contenção da circulação de doenças infectocontagiosas como a Covid-19. No subcontinente sul-americano, todos os países adotaram tal estratégia nas semanas subsequentes ao início do evento pandêmico.

Em razão da emergência de saúde, contudo, alguns vizinhos sul-americanos colocaram em execução medidas mais severas à entrada e à circulação de pessoas em seus territórios, criando dificuldades para seus próprios cidadáos adentrarem seus países, e impuseram medidas e regras diferentes sobre o mesmo recorte territorial - a linha do limite internacional -, criando dificuldades aos vizinhos.

Entre as dissonâncias na implementação das medidas, o fechamento unilateral das fronteiras terrestres ocasionou a retenção de vários grupos de imigrantes nas linhas de fronteira, criando dificuldades aos pequenos municípios fronteiriços na assistência a grandes grupos de imigrantes, por longas temporadas. Em vários pontos da linha internacional da fronteira brasileira, diversos grupos de imigrantes foram retidos desde o início da pandemia. Já em sentido contrário, na linha fronteiriça peruana com o Brasil, um grupo de venezuelanos permaneceu por vários meses aguardando a abertura da fronteira.

Para evitar todos esses prejuízos infligidos aos imigrantes (longos confinamentos na linha internacional em condiçôes desfavoráveis), os países amazônicos fronteiriços poderiam ter adotado medidas articuladas em relaçáo à migração e à mobilidade fronteiriça: focar em testagens, quarentena, isolamento e rastreamento dos doentes, e em açóes e medidas mais efetivas na repatriação de imigrantes que se encontravam em processo de deslocamento por ocasião do fechamento das fronteiras terrestres, garantindo, assim, os direitos humanos das pessoas migrantes.

\section{REFERÊNCIAS}

ACRE. Prefeitura Municipal de Assis Brasil. Decreto n⿳o 044, de 31 de março de 2020. Declara [dispóe sobre o estado de calamidade pública no município de Assis Brasil afetado por doenças infecciosas virais]. Diário do Estado do Acre, Acre, v. único, ano LIII, n. 12.772, p. 41, 2 abr. 2020 .

CAVALCANTI, L.; OLIVEIRA, T.; MACEDO, M. (Org.). Imigração e refúgio no Brasil: a inserção de imigrantes, solicitantes de refúgio e refugiados no mercado de trabalho. Brasília: OBMigra, 2019. (Relatório Anual). Disponível em: <https://portaldeimigracao.mj.gov.br/images/ relatorio-anual/RELAT\%C3\%93RIO\%20ANUAL\%20OBMigra\%202019.pdf>. Acesso em: 24 jun. 2020.

ICMPD - INTERNATIONAL CENTRE FOR MIGRATION POLICY DEVELOPMENT.

MT Brasil: migraçóes transfronteiriças - fortalecendo a capacidade do governo federal para gerenciar novos fluxos migratórios. Viena: ICMPD, 2016. Disponível em: <https://www. justica.gov.br/sua-protecao/trafico-de-pessoas/publicacoes/anexos-pesquisas/mtbrasil_act-1-31-4_relatorio_final.pdf>. Acesso em: 17 jun. 2020.

OBMIGRA - OBSERVATÓRIO DAS MIGRAÇÓES INTERNACIONAIS. Imigraçáo e refúgio no Brasil. Brasília: OBMigra, 2019. (Relatório Anual). Disponível em: <https:// portaldeimigracao.mj.gov.br/images/publicacoes-obmigra/RESUMO\%20EXECUTIVO\%20 _\%202019.pdf>. Acesso em: 18 jun. 2020. 
. Acompanhamento de fluxo e empregabilidade dos imigrantes no Brasil, ano 1, n. 4, abr. 2020. (Relatório Mensal). Disponível em: <https://portaldeimigracao.mj.gov.br/images/ relatorios_mensais/2020/OBMigra_Abril_2020.pdf>. Acesso em: 23 jun. 2020.

PÊGO, B. et al. Pandemia e fronteiras brasileiras: análise da evolução da Covid-19 e proposições. Brasília: Ipea, 2020. (Nota Técnica, n. 16). Disponível em: <https://www.ipea.gov.br/portal/ images/stories/PDFs/nota_tecnica/200521_n_16_dirur.pdf>. Acesso em: 25 maio 2020. 


\title{
UMA CARACTERIZAÇÃO DOS MUNICÍPIOS SEM DECLARAÇÕES DE RECEITAS ANUAIS NA BASE FINANÇAS DO BRASIL: DADOS CONTÁBEIS DOS MUNICÍPIOS (2013-2018) ${ }^{1}$
}

\author{
Rodrigo Luis Comini Curi \\ Luís Gustavo Vieira Martins ${ }^{3}$ \\ Marco Aurélio Costa ${ }^{4}$
}

\begin{abstract}
1 INTRODUÇÃO
No âmbito da descentralização administrativa e tributária ensejada pela Constituição Federal de 1988, bem como das exigências impostas pela Lei de Responsabilidade Fiscal (LRF), Lei Complementar (LC) no 101/2000, ao equilíbrio e controle das finanças públicas, as demandas pelo acesso às informaçôes fiscais e orçamentárias dos entes da Federação se tornou progressiva (Medeiros et al., 2014). A elaboração e a implementação de políticas públicas nos municípios brasileiros podem, de fato, se tornar mais efetivas quando as informaçôes sobre a situação socioeconômica desses entes podem ser associadas ao perfil e dinâmica das suas fontes de recursos e à sua capacidade de gasto, quando estas se mostram confráveis, abrangentes e de fácil acesso.

Nesse contexto, esse trabalho tem por objetivo investigar os municípios que não possuem informações na base Finanças do Brasil: Dados Contábeis dos Municípios (Finbra), no que diz respeito às suas receitas anuais. O Finbra é um banco de dados que reúne, entre outras informaçóes, os resultados fiscais e contábeis de natureza autodeclarada pelos municípios, que devem ser encaminhados a cada exercício, e consolidados pela Secretaria do Tesouro Nacional (STN). Desde 2014, com a criação do Sistema de Informaçôes Contábeis e Fiscais do Setor Público Brasileiro (Sincofi), desenvolvido pela STN em parceria com o Serviço Federal de Processamento de Dados (Serpro), tais informaçôes passaram a ser enviadas à STN por meio eletrônico, promovendo uma alternativa às declaraçóes antes consolidadas pelos municípios em documentos físicos e disquetes, enviados à STN por meio de terceiros. ${ }^{5}$

1. DOl: http://dx.doi.org/10.38116/brua24art5.

2. Assistente de pesquisa III na Diretoria de Estudos e Políticas Regionais, Urbanas e Ambientais (Dirur) do Ipea.

3. Analista de planejamento e orçamento em exercício na Dirur/lpea; e pesquisador em políticas públicas e desenvolvimento territorial (INPuT) do Instituto Nacional de Ciência e Tecnologia (INCT).

4. Técnico de planejamento e pesquisa na Dirur/Ipea; e coordenador nacional do INPut/INCT.

5. Disponível em: <https://siconfi.tesouro.gov.br/siconfi/pages/public/conteudo/conteudo.jsf?id=21904>.
\end{abstract}


Este texto considera as Declaraçôes de Contas Anuais (DCAs) municipais referentes aos resultados de suas receitas orçamentárias (DCA-RB, anexo I-C do Manual de Contabilidade Aplicado ao Setor Público). Como o Sincofi entrou em funcionamento em 2014, recebendo informações do exercício anterior, 2013, este trabalho considera os exercícios de 2013 a 2018, uma vez que os dados de 2019 e 2020 estáo ainda em processo de consolidaçáo no momento em que este artigo é escrito. ${ }^{6}$

A base Finbra é de extrema relevância para a análise sobre as finanças municipais, uma vez que se constitui na fonte de informaçóes mais abrangente sobre esse universo. No entanto, apesar de ter sido aperfeiçoada consistentemente ao longo do tempo, ainda possui diversas imperfeiçóes, dado que algumas prefeituras ou não prestam contas anualmente à STN ou registram os dados de modo inadequado (Orair e Alencar, 2010). Nesse sentido, se fazem pertinentes alguns comentários sobre o processo de declaração das informaçôes orçamentárias pelos municípios e de constituição da base Finbra.

O Finbra corresponde à DCA, para fins de cumprimento do art. 51 da LRF, e visa dar suporte ao processo anual de consolidaçáo nacional e por esfera de governo das contas dos entes da Federação relativas ao exercício anterior (até o dia 30 de junho de cada ano), pelo governo federal. O prazo para entrega dos dados pelos municípios vai até 30 de abril de cada ano.

Conforme definido no $\$ 4^{\circ}$ do art. 48 da LRF, ${ }^{7}$ a inobservância das regras da norma de que trata do tema ${ }^{8}$ impedirá, até que a situação seja regularizada, que o ente da Federação receba transferências voluntárias e contrate operaçóes de crédito, exceto as destinadas ao refinanciamento do principal atualizado da dívida mobiliária. Esse item também compóe o Serviço Auxiliar de Informaçóes para Transferências Voluntárias (Cauc). Outra forma passível de sanção na ausência de declaraçôes municipais poderá advir caso a STN identifique indícios de descumprimento do disposto nas regras do Manual de Contabilidade Aplicada ao Setor Público (MCASP) vigente. O formato e a estrutura da DCA devem ser compatíveis com as regras estabelecidas, inclusive as relativas ao Plano de Contas Aplicado ao Setor Público (PCASP), como forma de verificação do efetivo cumprimento dos arts. 11 e 12 da Portaria STN no 634, de 19 de novembro de 2013. Com a finalidade de avaliaçáo da qualidade da informaçáo contábil, poderáo ser criados, na forma do inciso II do art.15, indicadores qualitativos obtidos da DCA relacionados à implantaçáo, na forma e prazos previstos pelo Plano de Implantação dos Procedimentos Contábeis Patrimoniais aprovado pela Portaria STN no 548, de 24 de setembro de 2015, dos procedimentos referidos nos arts. 6o e 7o $\mathrm{da}$ Portaria STN no 634, de 2013. A STN deve comunicar ao respectivo tribunal de contas e ao conselho profissional de contabilidade os fatos encontrados, o que poderá redundar em punições aos envolvidos.

Salvo as restriçôes acima apontadas, não existe nenhum mecanismo de sanção direta aos municípios, especificamente pelo fato de não declararem suas contas ao Finbra ou o fazerem com ausências ou atrasos, e a STN não se responsabiliza pelo preenchimento ou organização de informaçóes ausentes nessa base de dados. Muitos municípios que não têm previsão de

6. Os dados do Finbra para a elaboração deste artigo foram consultados em 24 de julho de 2020.

7. A obrigatoriedade quanto à publicação dos demonstrativos fiscais está disciplinada na LRF, nos arts. 52 e 54. Adicionalmente, 0 § 2ำ do art. 48 da LRF dispõe que os entes da Federação disponibilizarão suas informações e dados contábeis, orçamentários e fiscais conforme periodicidade, formato e sistema estabelecidos pelo órgão central de contabilidade da União, que é a Secretaria do Tesouro Nacional.

8. Portaria no 896, de 31 de outubro de 2017, da STN, que regulamenta a entrega das informações. 
receber transferências voluntárias ou contratar financiamentos só entregam esses dados posteriormente, apenas quando se torna estritamente necessário fazê-lo para viabilizar tais operaçóes. A partir desses espaços, é possível que a base se mostre incompleta ou enviesada para alguns municípios. Importante ressaltar que, mesmo com essas questóes, a base Finbra é de extrema importância para a análise de dados orçamentários e contábeis municipais.

Este artigo apresenta um perfil dos municípios que, a cada ano, não declararam suas receitas anuais à STN,${ }^{9}$ construído a partir de suas características populacionais, geográficas e socioeconômicas, com o objetivo de contribuir com a construção e consolidação de bases informacionais sobre as finanças municipais no Brasil. Para este trabalho, consideramos apenas os municípios que não informaram nenhuma de suas receitas ao Finbra, e que, portanto, não estão presentes na base. No entanto, é possível que municípios presentes no Finbra tenham declarado apenas parte de suas contas, tendo, portanto, ausências em contas específicas. Conforme mencionado acima, devido à sua natureza voluntária, a ausência de declaração de contas específicas pode ocorrer devido ao fato de um município náo possuir determinada receita ou mesmo possuir, porém não a ter preenchido na DCA que compóe o Finbra. Também ocorrem casos em que o município preenche a informaçáo no campo equivocado ou comete erros de digitação. Devido ao extenso e complexo trabalho de levantamento e preenchimento dessas lacunas, ${ }^{10}$ este trabalho se debruça apenas sobre os municípios que não estáo presentes na base, ou seja, que não declararam nenhuma conta à STN no âmbito da composição do Finbra. Ele se mostra importante para se ter um quadro da dimensão da ausência de informaçóes nessa fonte de dados, da representatividade das informaçôes presentes na base e das características desses municípios sem participação no Finbra.

Por fim, é importante denotar que este artigo se insere no conjunto de pesquisas da Dirur/Ipea no apoio à construção da Política Nacional de Desenvolvimento Urbano (PNDU), junto ao Ministério do Desenvolvimento Regional e outras instituiçôes. Os dados do Finbra se colocam como uma fonte de informação central para a investigação das perspectivas e desafios para o financiamento do desenvolvimento urbano, sendo utilizados para a análise do quadro de arrecadação municipal, de seu balanço entre receitas próprias e transferências, do comportamento das despesas municipais e do direcionamento de gastos para o desenvolvimento urbano.

\section{CARACTERÍSTICAS DOS MUNICÍPIOS AUSENTES DA BASE DE DECLARAÇÕES DE RECEITAS ANUAIS DO FINBRA}

Ao se considerar os 5.570 municípios existentes no Brasil entre 2013-2018, em cada ano parte deles não disponibiliza seus dados do Finbra/Sincofi de declaraçôes de receitas brutas

\footnotetext{
9. Importante notar que não necessariamente são os mesmos municípios que estão ausentes a cada ano, tendo esse número de ausentes variado entre 2013 e 2018.

10. A STN atualmente não depura esses dados ausentes ou com erros de preenchimento, e suprir as lacunas de informação demandaria uma extensa pesquisa nos 26 Tribunais de Contas Estaduais (TCEs) e até mesmo diretamente nas contas municipais, pois alguns destes sequer as entregam aos TCEs. Outra limitação para depuração reside no fato de que apenas cerca da metade dos TCEs possui bases de dados estruturadas para disponibilização e tratamento adequado das informações. Esse fato foi debatido com a STN e com a área de contas nacionais do Instituto Brasileiro de Geografia e Estatística (IBGE), que há décadas realiza a análise conjuntamente com a STN para elaboração das contas nacionais. Foi verificado, inclusive, que em muitos casos os dados dos TCEs não possuem qualidade de informação superior à do Finbra. Os dados depurados caso a caso pelo IBGE restringem-se às capitais e governos estaduais, devido à sua maior relevância.
} 
realizadas, ${ }^{11}$ cujos números são demonstrados no gráfico 1 . Apesar de não mostrar um padrão específico, para a maioria dos anos a quantidade de não informantes era menor que 150 , com exceção de 2014, em que 381 municípios não constaram na base de receitas do Finbra. ${ }^{12}$ É importante considerar que, mesmo náo tendo todos os municípios respondido ao Finbra ano a ano, essa base se mostra significativamente representativa. Em 2018, os municípios informantes representaram $98,17 \%$ da populaçáo brasileira, e, em 2017, os que responderam ao Finbra representaram $96 \%$ do produto interno bruto (PIB) do país. ${ }^{13}$

A seguir, serão apresentadas algumas características populacionais, geográficas e socioeconômicas dos municípios ausentes em cada ano, de modo a investigar o perfil municipal de não aderência às declarações anuais por meio eletrônico consolidadas na plataforma Sincofi.

GRÁFICO 1

Municípios ausentes da DCA-RB (2013-2018)

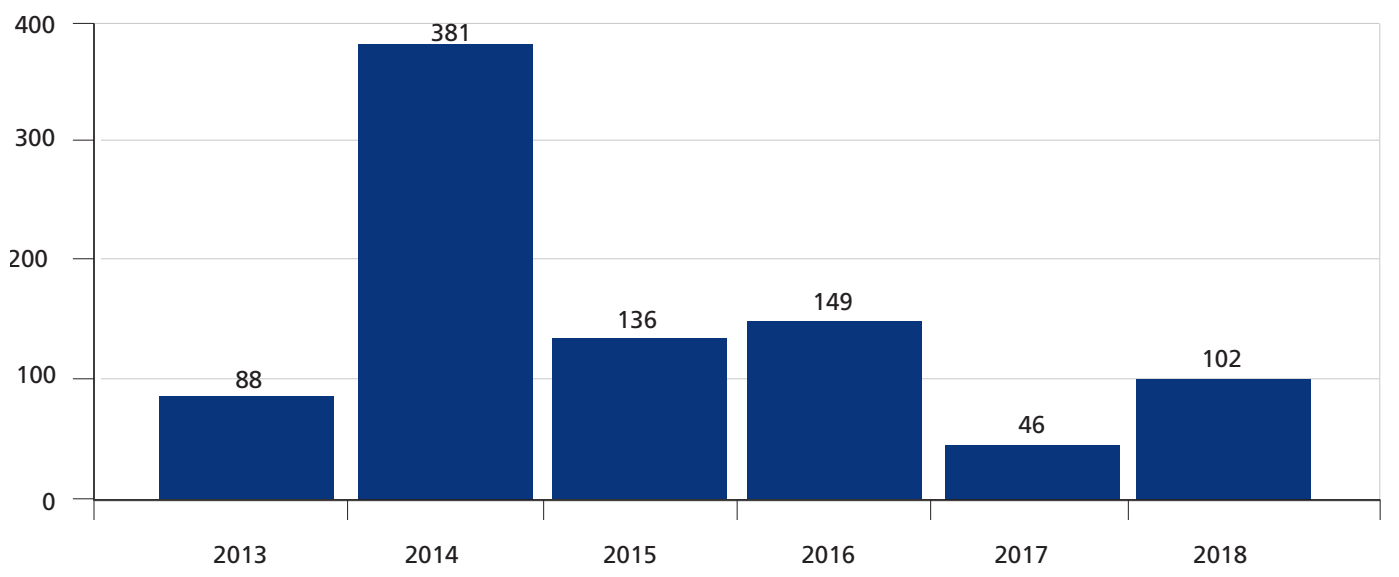

Fonte: Sincofi/STN; Finbra.

\subsection{Características populacionais dos municípios}

A tabela 1 apresenta a distribuição dos municípios em cada ano em relação a sua população total, de acordo com as estimativas populacionais dos municípios realizada pelo IBGE $^{14}$ e disponíveis no Sistema IBGE de Recuperação Automática (Sidra). Para todos os anos, a maioria dos municípios não informantes possuíam entre 5 mil e 50 mil habitantes. ${ }^{15}$

11. Este estudo considera apenas as receitas brutas declaradas pelos municípios, não incorporando a declaração de suas deduções de receita. Sendo assim, no recorte temporal adotado, apenas em 2013 existem três municípios que não possuem receitas brutas realizadas na base de receitas disponível pelo Sincofi, sendo, portanto, considerados neste texto, mas possuem algumas deduções. São eles: São Miguel de Taibu, na Paraíba; Duas Barras, no Rio de Janeiro; e Sucupira do Riachão, no Maranhão.

12. Na comparação entre municípios, sete municípios são comuns a todos os anos: Curralinho, Muaná e Santarém Novo, no Pará; Rafael Fernandes, no Rio Grande do Norte; Fernando de Noronha, em Pernambuco; Flexeiras, em Alagoas; e Aperibé, no Rio de Janeiro. Todos são municípios com população entre 3 mil e 40 mil habitantes. Brasília também não consta no Finbra, sendo tratada de forma diferente devido ao seu status de capital nacional.

13. Dados auxiliares extraídos das estimativas populacionais e do PIB municipal, realizadas pelo IBGE. Para o PIB, o ano mais recente em que os dados municipais estavam disponíveis no Sidra no período em que este texto foi escrito era de 2017. 14. Mais informações sobre as estimativas das populações dos municípios (EstimaPop) disponíveis em: <https://metadados. ibge.gov.br/consulta/estatisticos/operacoes-estatisticas/XF>.

15. Excluímos Brasília dessa e das análises subsequentes, uma vez que o Distrito Federal possui ordenamento jurídico específico, que inclui competências dos entes estaduais. 
O único município do grupo entre 300 mil e 750 mil habitantes ausente do Finbra foi Caruaru, Pernambuco, em 2014, com uma população de 342.328 habitantes nesse ano. Chamam a atenção também alguns municípios entre 100 mil e 300 mil habitantes ausentes da base considerada. Para esse grupo populacional, Altamira, no Pará, aparece como não informante em todos os anos entre 2015 e 2018.

TABELA 1

Municípios ausentes em cada ano por grupo populacional (2013-2018)

\begin{tabular}{|c|c|c|c|c|c|c|}
\hline Porte populacional & 2013 & 2014 & 2015 & 2016 & 2017 & 2018 \\
\hline Até 5 mil & 31 & 88 & 19 & 16 & 6 & 28 \\
\hline $5 \mathrm{mil} \mathrm{a} 10 \mathrm{mil}$ & 11 & 102 & 31 & 33 & 13 & 29 \\
\hline 10 mil a 20 mil & 25 & 96 & 37 & 41 & 13 & 20 \\
\hline $20 \mathrm{mil} \mathrm{a} 50 \mathrm{mil}$ & 20 & 61 & 40 & 45 & 9 & 19 \\
\hline 50 mil a 100 mil & - & 18 & 6 & 10 & 3 & 2 \\
\hline $100 \mathrm{mil} \mathrm{a} 300 \mathrm{mil}$ & - & 14 & 2 & 3 & 1 & 3 \\
\hline 300 mil a 750 mil & - & 1 & - & - & - & - \\
\hline Acima de 750 mil & - & - & - & - & - & - \\
\hline Total & 88 & 381 & 136 & 149 & 46 & 102 \\
\hline
\end{tabular}

Fonte: Sincofi/STN; Finbra; IBGE.

Obs.: Para cada grupo populacional, os dados são inclusivos no limite inferior e exclusivos no superior.

O gráfico 2 mostra a distribuição dos municípios ausentes em cada ano, segundo a porcentagem da população residente em áreas rurais em relação ao total populacional, referentes ao censo demográfico de 2010 do IBGE. ${ }^{16}$ Para os anos de 2013, 2015 e 2016, mais da metade dos municípios náo declarantes a cada ano possuíam pelo menos $50 \%$ da sua população residente em áreas rurais, sendo a mediana em 2017 muito próxima desse resultado. Importante notar que esse resultado se refere a 2010, sendo possível que esse balanço populacional tenha mudado, especialmente para anos mais recentes, como $2017 \mathrm{e}$ 2018. No entanto, esses dados mostram que grande parte dos municípios náo informantes tem a maioria de seu contingente populacional em áreas rurais.

\section{GRÁFICO 2}

Distribuição dos municípios ausentes em 2010 (2013-2018)

(Em \% da população rural)

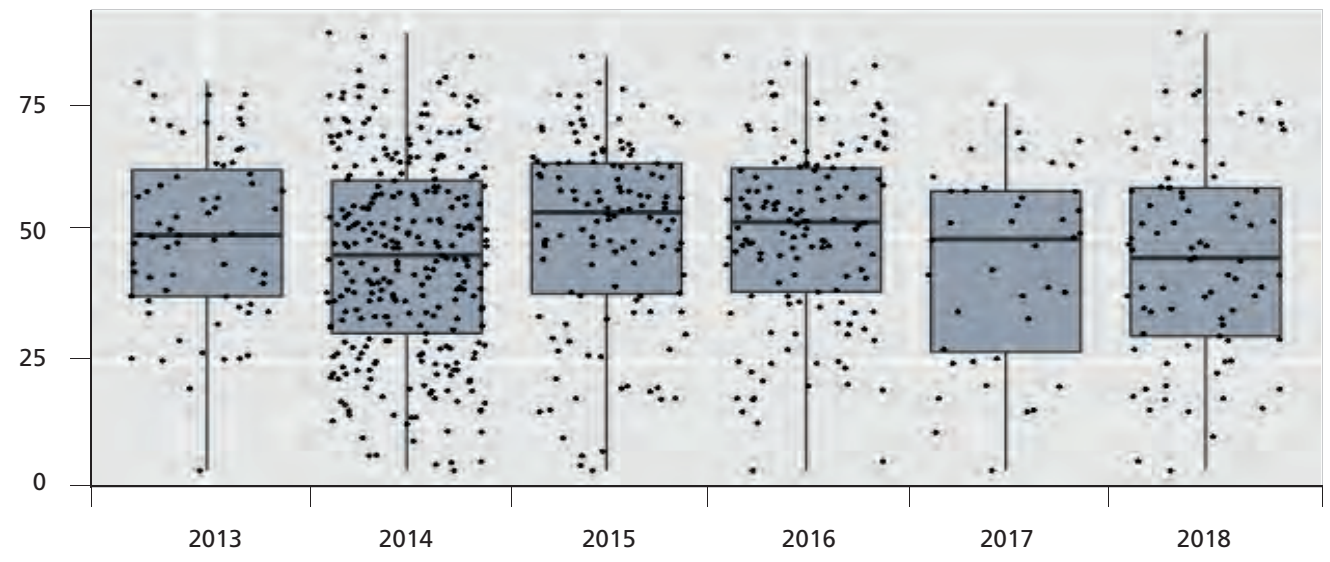

Fonte: Sincofi/STN; Finbra; Ipea.

16. Dados extraídos da plataforma Atlas da Vulnerabilidade Social, do Ipea, referente ao censo demográfico de 2010. Devido a questões de amostragem, nem todos os 5.565 municípios de 2010 foram desagregados para situações de domicílio (rural e urbano). 


\subsection{Características geográficas dos municípios}

A tabela 2 apresenta a distribuição dos municípios por região. A maioria dos anos mostrou um número maior de municípios ausentes da base na regiáo Nordeste, seguida do Norte. As regióes Centro-Oeste e Sul foram aquelas com menor número de municípios ausentes. A exceção se dá em 2014, em que o maior número de municípios se mostrou nas regiôes Sul e Sudeste, seguido do Nordeste. $\mathrm{O}$ ano de 2016 chama a atençáo pela grande diferença entre o número de municípios ausentes nas regiôes Norte e Nordeste, quando comparadas com as demais do país, todas na casa de um dígito, enquanto o Nordeste mostrou quase oitenta municípios sem adesão ao Finbra/Sincofi naquele ano.

\section{TABELA 2}

Região dos municípios ausentes (2013-2018)

\begin{tabular}{lcccccc}
\hline Região & 2013 & 2014 & 2015 & 2016 & 2017 & 2018 \\
\hline Centro-Oeste & 14 & 50 & 8 & 5 & 5 & 26 \\
Nordeste & 30 & 88 & 63 & 78 & 21 & 38 \\
Norte & 25 & 40 & 47 & 54 & 15 & 18 \\
Sudeste & 11 & 96 & 14 & 9 & 4 & 14 \\
Sul & 7 & 106 & 3 & 2 & - & 5 \\
\hline
\end{tabular}

Fonte: Sincofi/STN; Finbra.

Além da macrorregiáo desses municípios, cabe o questionamento se o município faz parte de uma região metropolitana (RM), o que podemos entender como uma proxy para um município com maior dinâmica socioeconômica e de relaçôes com outros territórios. O gráfico 3 mostra a distribuição dos municípios ausentes ano a ano por posição em relação a uma RM brasileira, divididos em três grupos: municípios institucionalmente pertencentes a uma RM mas que não são sede, municípios que são capitais metropolitanas (sede) e outros municípios que não pertencem institucionalmente a uma RM (outros).

GRÁFICO 3

Caracterização dos municípios ausentes em relação à posição na RM (2013-2018)

2013
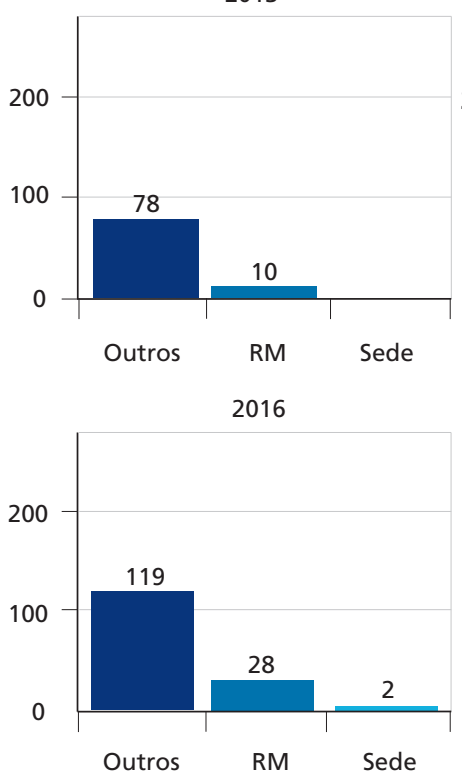

2014
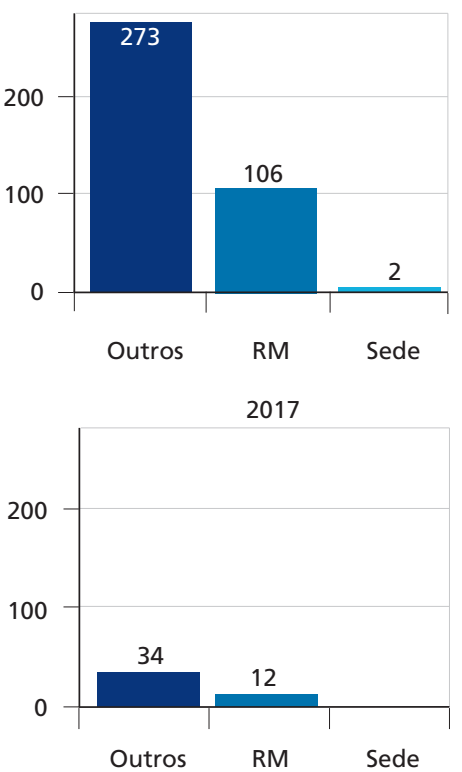

2015

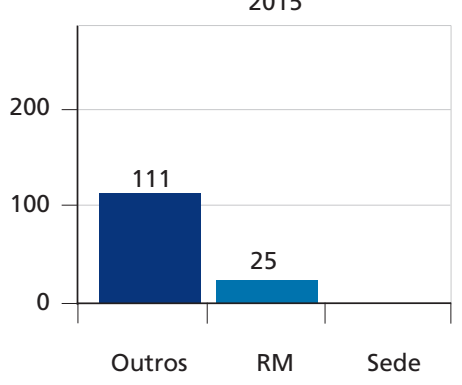

2018

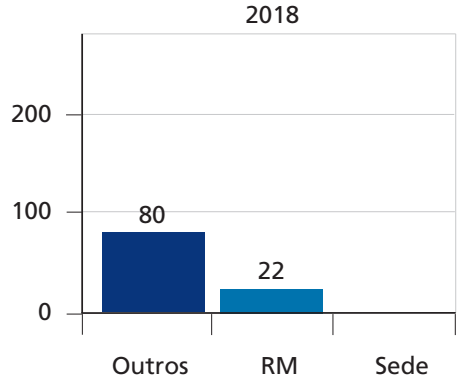

Fonte: Sincofi/STN; Finbra; Atlas da Governança Metropolitana no Brasil, disponível em: <http://brasilmetropolitano.ipea.gov.br/>. 
O gráfico mostra que, para todos os anos considerados, a maioria dos municípios que não constaram na base de receitas anuais do Finbra/Sincofi não faz parte de uma RM, sendo o balanço entre metropolitanos e não metropolitanos diferente ao longo dos anos (em 2017, esses números foram mais próximos que nos outros anos). Com exceção de 2014, em que o número de não adesóes ao Finbra foi destacadamente maior em relação aos outros anos, o maior número de municípios ausentes pertencentes à alguma RM ocorreu em 2016. Esse ano também, junto com 2014, foram os únicos em que sedes metropolitanas não se encontravam na base do Finbra. Em 2016, esses municípios foram Caracaraí, sede da RM central, em Roraima; e Itabaiana, sede da RM de Itabaiana, na Paraíba. Por sua vez, em 2014, as duas ausentes foram Patos, sede da RM de Patos, na Paraíba, e Palmeira dos Índios, sede da RM de Palmeira dos Índios, em Alagoas.

Um outro olhar com relação às características dos municípios que não aderiram ao Finbra no recorte temporal adotado se dá na sua posição na Região de Influência das Cidades (Regic), estudo realizado periodicamente pelo IBGE. Apesar de considerar também a proximidade geográfica entre os municípios, a Regic aborda diversos outros aspectos municipais, com o intuito de analisar a rede urbana brasileira e estabelecer hierarquias de centros urbanos e regióes de influência das cidades, tais como movimentos pendulares de trabalho, trocas comerciais, ocorrência de eventos culturais, entre outros. ${ }^{17}$

A tabela 3 mostra a distribuição desses municípios em relação à hierarquia dos centros urbanos da Regic, a saber: metrópoles, correspondentes aos principais centros urbanos, com ampla influência sobre o território nacional; capitais regionais, com menor alcance de influência comparadas com as metrópoles, mas com alta concentração de atividades de gestão; os centros sub-regionais, com atividades de gestão menos complexas, menor região de influência e porte populacional; centros de zona, já com menores níveis de atividades de gestão e relaçôes comerciais e de serviços baseadas na proximidade com outras regióes; e os centros locais, cidades que exercem influência restrita a seus próprios limites territoriais, podendo atrair populaçóes de outros territórios mas não sendo o seu destino principal.

TABELA 3

Distribuição dos municípios ausentes em relação à posição na Regic (2013-2018)

\begin{tabular}{lcccccc}
\hline Regic & 2013 & 2014 & 2015 & 2016 & 2017 & 2018 \\
\hline Centro local & 85 & 323 & 122 & 131 & 82 & 88 \\
Centro de zona & 1 & 28 & 6 & 5 & 1 & 7 \\
Centro sub-regional & - & 14 & 4 & - & - & - \\
Capital regional & - & 2 & - & - \\
Metrópole nacional & - & - & - & - \\
\hline
\end{tabular}

Fonte: Sincofi/STN; Finbra; IBGE.

A tabela aponta que em todos os anos a maioria dos municípios ausentes correspondia a centros locais na classificaçáo hierárquica da Regic, seguidos de centros de zona e centros sub-regionais. $\mathrm{O}$ ano de 2014 foi o único em que se registrou a ausência de capitais regionais no Finbra, apenas duas: Araguaína, Tocantins, e Caruaru, Pernambuco.

17. Para mais informações sobre a Regic, ver IBGE (2020). 


\subsection{Características socioeconômicas}

O terceiro bloco de características municipais levanta alguns aspectos socioeconômicos dos municípios. A tabela 4 apresenta uma classificação municipal com base em grupos de renda per capita, a partir dos dados do censo demográfico de 2010. A partir dos resultados apresentados, percebe-se uma concentração de municípios nas faixas de renda per capita média de $\mathrm{R} \$ 100,00$ a $\mathrm{R} \$ 500,00$, abaixo da média do Brasil no período em que o censo foi realizado, de $\mathrm{R} \$ 793,87$. Tanto em 2015 quanto em 2016 apenas um município se encontrava com renda per capita menor de R \$100,00, a saber, o município de Marajá do Sena, no Maranhão. À exceção de 2014, poucos municípios apresentaram renda per capita acima de $\mathrm{R} \$ 500,00$.

TABELA 4

Renda per capita dos municípios ausentes em $2010^{1}$ (2013-2018)

\begin{tabular}{|c|c|c|c|c|c|c|}
\hline Renda per capita & 2013 & 2014 & 2015 & 2016 & 2017 & 2018 \\
\hline Até $\mathrm{R} \$ 100$ & - & - & 1 & 1 & - & - \\
\hline$R \$ 100$ a $R \$ 200$ & 15 & 15 & 26 & 36 & 6 & 11 \\
\hline$R \$ 200$ a $R \$ 300$ & 31 & 85 & 59 & 67 & 23 & 36 \\
\hline$R \$ 300$ a $R \$ 500$ & 22 & 95 & 35 & 31 & 9 & 23 \\
\hline$R \$ 500$ a $R \$ 1.000$ & 17 & 176 & 13 & 12 & 6 & 29 \\
\hline$R \$ 1.000$ a $R \$ 1.500$ & 2 & 9 & 1 & 1 & 1 & 2 \\
\hline Acima de $R \$ 1.500$ & - & - & - & - & - & - \\
\hline
\end{tabular}

Fonte: Sincofi/STN; Finbra; Ipea.

Nota: ${ }^{1}$ Em reais de agosto de 2010.

Em complementação à análise da renda per capita, o gráfico 4 apresenta a distribuição dos municípios pelo valor do Índice de Vulnerabilidade Social (IVS), em 2010. O IVS é um índice sintético desenvolvido pelo Ipea com o intuito de identificar e mapear no território brasileiro situaçôes de vulnerabilidade social. ${ }^{18}$ Ele é composto por dezesseis indicadores divididos em três dimensóes - capital humano, renda e trabalho e infraestrutura urbana. Seus valores variam de 0 a 1 , divididos em cinco faixas de vulnerabilidade: 0 a 0,200 (muito baixa), 0,201 a 0,300 (baixa), 0,301 a 0,400 (média), 0,401 a 0,500 (alta), e 0,500 a 1 (muito alta).

Pelo gráfico, novamente com exceção de 2014, percebe-se que em todos os anos a maioria dos municípios mostrava um IVS nas faixas de alta e muito alta vulnerabilidade social, sendo o ano de 2016 com menor variabilidade nos valores municipais. Junto com 2015, foram os dois anos em que pelo menos metade dos municípios em cada ano mostraram um IVS acima de 0,500, caracterizando situaçôes de muito alta vulnerabilidade social. Por sua vez, talvez por ter um grupo maior de municípios que não aderiram ao Finbra, 2014 mostrou uma maior concentração de seus municípios ausentes em faixas mais baixas do IVS, abaixo de 0,300 .

18. O IVS identifica situações de vulnerabilidade social entendidas como a falta ou insuficiência de ativos essenciais para 0 bem-estar de um individuo ou grupo populacional, em que o acesso a tais ativos não depende somente do indivíduo, mas é também responsabilidade do Estado ofertá-lo. Para mais informações sobre o IVS, ver Costa et al. (2018). 
GRÁFICO 4

IVS dos municípios ausentes em 2010 (2013-2018)

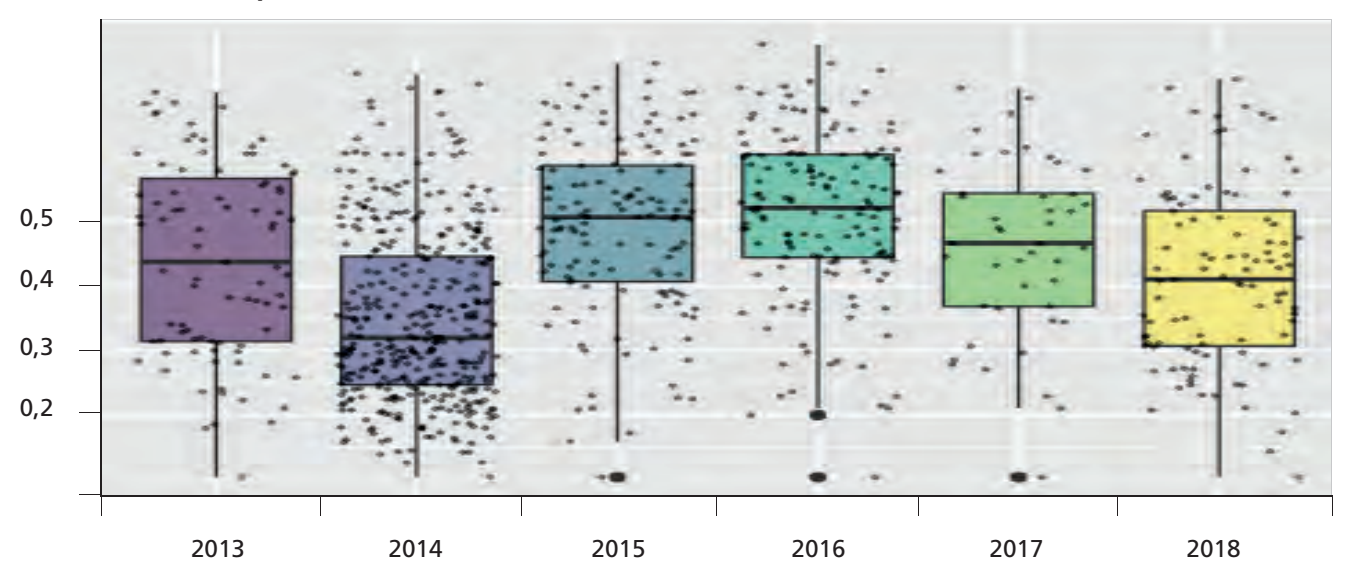

Fonte: Sincofi/STN; Finbra; Ipea.

Por fim, o gráfico 5 mostra a distribuição dos municípios ausentes em cada ano pelo valor do Índice de Desenvolvimento Humano Municipal (IDHM), uma versão do Índice de Desenvolvimento Humano (IDH) desenvolvida pelo Ipea, Programa das Naçóes Unidas para o Desenvolvimento (Pnud) Brasil e Fundação João Pinheiro (FJP), adaptada à realidade brasileira. Esse índice sintético busca identificar o nível de desenvolvimento humano no território nacional, a partir de uma estrutura baseada em sete indicadores divididos em três dimensôes: longevidade, educação e renda. Também é um índice que varia de 0 a 1 , porém, de forma oposta ao IVS: quanto mais próximo o IDHM for de 1, maior seria a indicação de desenvolvimento humano no território. O IDHM é também dividido em cinco faixas: 0 a 0,499 (muito baixo), 0,500 a 0,599 (baixo), 0,600 a 0,699 (médio), 0,700 a 0,799 (alto) e 0,800 a 1 (muito alto).

Os anos de 2013, 2018 e especialmente 2014 mostraram uma mediana mais elevada em relação a 2015, 2016 e 2017, com mais da metade dos municípios com IDHM acima de 0,600 (médio desenvolvimento humano). Os anos de 2013, 2017 e 2018 mostraram uma maior dispersão no valor do IDHM para seus respectivos municípios, diferentemente de 2015 e 2016, em que há uma concentração maior dos valores municipais em faixas mais baixas, abaixo do médio IDHM.

\section{GRÁFICO 5}

IDHM dos municípios ausentes em 2010 (2013-2018)

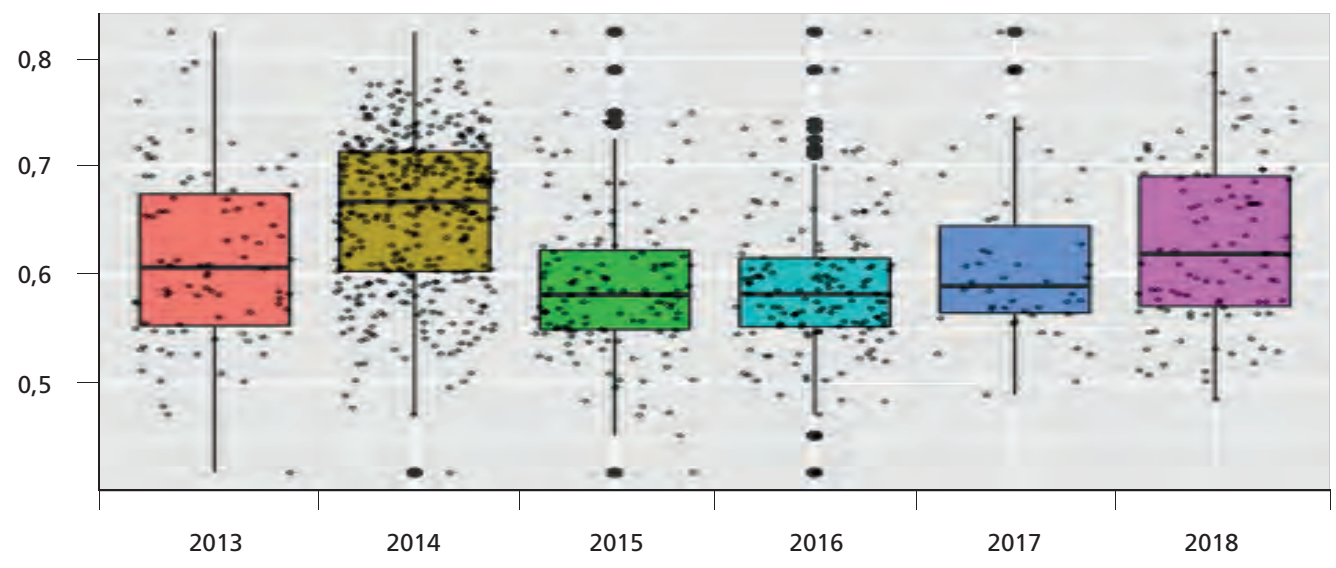

Fonte: Sincofi/STN; Finbra; Ipea. 


\section{CONSIDERAÇÕES FINAIS}

Este breve artigo procurou identificar algumas características populacionais, geográficas e socioeconômicas dos municípios que não estão presentes na base de autodeclaração do Finbra, disponível na plataforma Sincofi/STN, no intuito de contribuir para o entendimento sobre a disponibilidade de dados fiscais e orçamentários dos municípios e para as futuras construçóes e consolidaçóes de novas bases, ao caracterizar os municípios que náo aderiram à essa base sintética de dados Finbra.

Pode-se observar que o número de municípios náo informantes variou entre $0,8 \% \mathrm{e}$ $6,8 \%$ do total do país, o que aponta para uma alta adesão dos entes municipais ao Finbra. Entre os não informantes, predominam municípios de menor contingente populacional e menor grau de urbanização, em especial das regióes Nordeste e Norte do país, o que deve ser cotejado pelo número de municípios em cada uma dessas macrorregiôes.

Observou-se, também, um amplo predomínio de municípios não inseridos em regiôes metropolitanas e que exercem a posição de centro local na rede urbana brasileira, abrigando, na maior parte das vezes, uma populaçáo de rendimentos mais baixos e índices socioeconômicos menos favoráveis.

Este levantamento, que se insere na pesquisa de apoio à construção da Política Nacional de Desenvolvimento Urbano (PNDU), reforça a importância do acesso a dados e informaçóes sobre as finanças municipais e ratifica a pertinência das informaçóes disponibilizadas pela plataforma Sincofi/STN.

\section{REFERÊNCIAS}

COSTA, M. A. et al. Vulnerabilidade social no Brasil: conceitos, métodos e primeiros resultados para municípios e regiôes metropolitanas brasileiras. Brasília: Ipea, 2018. (Texto para Discussão, n. 2364).

IBGE - INSTITUTO BRASILEIRO DE GEOGRAFIA E ESTATÍSTICA. Regióes de Influência das Cidades 2018. Rio de Janeiro: IBGE, 2020.

MEDEIROS, K. R. de et al. Bases de dados orçamentários e qualidade da informação: uma avaliação do Finanças do Brasil (Finbra) e do Sistema de Informaçôes sobre Orçamentos Públicos em Saúde (Siops). Revista de Administraçáo Pública, v. 48, n. 5, p. 1113-1133, 1 set. 2014.

ORAIR, R. C.; ALENCAR, A. A. Esforço fiscal dos municípios: indicadores de condicionalidade para o sistema de transferências intergovernamentais. Brasília: Esaf, 2010. 


\section{A ATUAÇÃO GOVERNAMENTAL EM SÃO GABRIEL DA CACHOEIRA NO AMAZONAS DURANTE A CRISE DA COVID-19'}

Rodrigo Portugal²

\section{INTRODUÇÃO}

O município de São Gabriel da Cachoeira é banhado pelo rio Negro e fica localizado no noroeste do Amazonas, na região conhecida como cabeça do cachorro. É lá que está localizado o pico da Neblina, o ponto mais alto do Brasil, com quase 3 mil metros de altitude, e é também o município com o maior percentual de indígenas - cerca de $90 \%$ - entre seus 45 mil habitantes, segundo estimativas do Instituto Brasileiro de Geografia e Estatística (IBGE) para 2020.

O município foi um dos principais pontos de proliferação da Covid-19 no Amazonas, registrando, até o início de agosto de 2020, 3.522 casos da doença, com 49 óbitos acumulados, segundo boletim do Sistema Único de Saúde (SUS). ${ }^{3}$ Até aquela data, foram 7.730 casos acumulados por 100 mil habitantes, um dos maiores valores proporcionais do Brasil. A peculiaridade do município se exalta quando a disseminação da doença ameaça de extinção certas etnias que vivem no seu território, que faz fronteira com a Venezuela e a Colômbia, colocando em risco culturas, línguas e hábitos ancestrais. Diante dessa idiossincrasia, o território demanda açóes governamentais distintas do restante do Brasil ou mesmo sugere adaptaçóes às açôes gerais.

Nesse contexto, o ensaio busca traçar um cenário da atuação governamental no enfrentamento da pandemia do coronavírus em São Gabriel da Cachoeira, destacando as açôes, articuladas ou não, de cada ente federativo (federal, estadual e municipal) no período de março a agosto de 2020, com o objetivo de identificar e discutir as açôes, partindo da ótica das finanças públicas e do território.

1. DOI: http://dx.doi.org/10.38116/brua24art6

2. Pesquisador visitante na Diretoria de Estudos e Políticas Regionais, Urbanas e Ambientais (Dirur) do Ipea; e economista da Superintendência do Desenvolvimento da Amazônia (Sudam).

3. Disponível em: <https://bit.ly/3agpMtt>. Acesso em: 10 ago. 2020. 


\section{ATUAÇÃO GOVERNAMENTAL}

\subsection{Governo federal}

A atuação do governo federal se pautou primordialmente pela transferência de recursos para os cidadáos do município. De acordo com dados recolhidos do Portal da Transparência, ${ }^{4} 62 \%$ ( $\mathrm{R} \$ 43$ milhóes) dos recursos aplicados na localidade em 2020 correspondiam a benefícios ao cidadáo - o auxílio emergencial equivaleu a quase $60 \%$ desse valor. Ressalta-se que $35 \%$ da população local recebeu o auxílio, percentual bem superior ao abrangido pelo Programa Bolsa Família (PBF) no período, que alcançou $15 \%$. As transferências diretas para os cofres públicos municipais corresponderam a um valor menor, na marca dos $\mathrm{R} \$ 26$ milhóes, e destaca-se que esse valor poderia ser ainda mais reduzido, uma vez que o governo federal aprovou, em finais de maio, a Lei Complementar (LC) no 173, de 27 de maio de 2020, que autorizou o auxílio financeiro da União para estados e municípios brasileiros, a fim de balancear o descenso das arrecadaçóes próprias dos entes subnacionais.

Nesse sentido, mesmo em um município com características fortemente indígenas e visto por muitos como isolado, dado o acesso apenas fluvial e aéreo, a presença do governo federal se fez importante, tanto pelas transferências aos cofres públicos municipais quanto pelas transferências aos cidadáos (por meio da única casa lotérica do município, que atua em lugar da Caixa Econômica Federal, que não possui agência no local). Em São Gabriel da Cachoeira, somente o Bradesco e o Banco do Brasil têm agências - nem mesmo o Banco da Amazônia S/A, banco federal de desenvolvimento regional, está presente no município.

O raro acesso da população pobre/indígena a contas bancárias e ao banco digital culminou em uma centralização dos pagamentos do auxílio na casa lotérica. Nos dias anunciados pelo governo federal, boa parcela dos indígenas se deslocou de suas aldeias - segundo a Fundação Nacional do Índio (Funai), são 23 etnias no território - e se direcionou para a sede do município para o recebimento do auxílio, causando aglomeraçóes. Houve também a ação de comércios paralelos para a emissão de boletos ou auxílios no saque, uma situação comum nas demais cidades brasileiras. Em São Gabriel da Cachoeira, porém, o aspecto de ida à casa lotérica ganha ares antropológicos e diferenciados pelo fato de as "periferias" serem aldeias indígenas, que também sofrem com mazelas sociais.

O deslocamento para o município aumenta o risco de transmissáo do vírus no retorno às aldeias, podendo causar um genocídio de alguns povos indígenas, possibilidade que fez o Ministério Público Federal (MPF) recomendar, ${ }^{5}$ ainda em abril, medidas diferenciadas, como: i) ampliação de prazo para saque; ii) escalonamento de datas por grupos indígenas; e iii) pagamento em unidades mais próximas das aldeias, como nos pelotôes de fronteira e nos centros de mídia da Secretaria de Educaçáo (Seduc) do Amazonas. Isso tudo, no entanto, parece não ter causado efeito, haja vista as persistentes aglomeraçóes em frente à lotérica em julho. ${ }^{6}$

A presença do MPF mostra a ação conjunta entre os Poderes e as várias instituiçôes do governo federal no combate ao vírus, que transborda as transferências monetárias. Em inícios de junho de 2020, o governo federal realizou uma ação interministerial ${ }^{7}$ que trouxe de Brasília equipamentos, vacinas e profissionais de saúde, contando com o suporte

4. Disponível em: <https://bit.ly/2ChnHRx>. Acesso em: 31 jul. 2020.

5. Disponível em: <https://bit.ly/33NXwNE>. Acesso em: 8 ago. 2020.

6. Disponível em: <https://bit.ly/3ah0rjp>. Acesso em: 8 ago. 2020.

7. Disponível em: <https://bit.ly/3gMCH9e>. Acesso em: 11 ago. 2020. 
das Forças Armadas, dos ministérios da Defesa e da Saúde na figura do Distrito Sanitário Especial Indígena (DSEI) e da Funai. A ação percorreu as aldeias da região durante sete dias e atendeu treze etnias, entre ianomamis, tucanos, tarianos e hupdás. Ademais, foram entregues cestas de alimentos para as populaçóes indígenas.

O governo federal é o ente federativo mais distante, teoricamente, do território, o que pôde causar auxílios físicos não tempestivos ou mesmo fugazes, como a missão de sete dias. Mesmo o auxílio emergencial e o auxílio às prefeituras são emergenciais e horizontais no território brasileiro, não incorporando questôes específicas, como o auxílio diferenciado aos indígenas em São Gabriel da Cachoeira. Para incorporar tais questóes, são imprescindíveis ações dos entes governamentais mais próximos do território, como os governos estaduais e municipais.

\subsection{Governo estadual}

O governo do estado, como em muitos outros municípios da Amazônia brasileira, tem uma participação diretamente menor sobre as finanças municipais, o que reverbera em açóes emergenciais, como o enfrentamento de uma pandemia. Os números do Relatório Resumido de Execução Orçamentária (RREO) de dezembro de 2019 demonstram que as cotas-partes do Imposto sobre Circulaçáo de Mercadorias e Serviços (ICMS) e do Imposto sobre a Propriedade de Veículos Automotores (IPVA), que são tributos estaduais em parte devolvidos ao município de origem, corresponderam a $17 \%$ da receita corrente líquida (RCL) - que naquele ano foi de R\$ 96 milhōes -, ao passo que o Fundo de Participação dos Municípios (FPM), federal, correspondeu a 27\%. Foram os recursos do Fundo de Manutenção e Desenvolvimento da Educação Básica e de Valorização dos Profissionais da Educação (Fundeb), porém, que se sobressaíram: chegaram a 43\% da RCL. ${ }^{8}$

O Fundeb não é federal nem estadual, é uma transferência interfederativa, cujas fontes são oriundas de tributos dos três entes. No entanto, segundo o Senado Federal, em fonte que subsidia a Proposta de Emenda à Constituição (PEC) no 15/2015, quase 90\% dos seus recursos em 2019 foram oriundos de impostos estaduais e municipais, ${ }^{9}$ na maior parte do ICMS, o maior imposto no rol das fontes. Portanto, o Fundeb é uma forma indireta de transferência dos estados para os municípios, apesar de a legislação e a gestão serem federais.

Nesse sentido, pode-se afirmar que o estado transferiu, indiretamente, em 2019, uma quantia significativa para São Gabriel da Cachoeira via Fundeb, porém com gastos vinculados à educação. Tal gasto é estrutural e conserva patamares de dispêndios com educação no município, o que é relevante para a manutenção do ensino das línguas indígenas nas escolas regulares, como o nheengatu, inclusive com a criação em 2020 pela prefeitura municipal do cargo de professor indígena I e II pela Lei Municipal no 135, de 28 de fevereiro de 2020.

O perfil das transferências diretas e indiretas do estado, entretanto, não configurou mesmo patamar aos gastos com saúde. No RREO de 2019, 18\% da RCL foi executada em serviços de saúde, voltada, sobretudo, para a atenção básica, o que significa que respiradores, leitos e oxigênio são escassos estruturalmente na regiâo. Na cidade só há o hospital de guarnição do Exército, que não possui unidades de terapia intensiva (UTIs) e contava com poucos respiradores. Ademais, nos últimos anos, o município viveu surtos de malária - que afetou $25 \%$ da população - e dengue, além da endemia de tuberculose, como apontaram Levino e Oliveira (2007), e de hanseníase, como denotado por Imbiriba et al. (2009). Isso demonstra

8. Disponível em: <https://bit.ly/3kySdb1>. Acesso em: 10 ago. 2020

9. Disponível em: <https://bit.ly/2DzhbGl>. Acesso em: 10 ago. 2020. 
as mazelas estruturais quanto ao atendimento de saúde na região, não somente na pandemia do coronavírus.

No caso da malária, em 2018, a Fundação de Vigilância em Saúde do Amazonas (FVS/AM) atuou no município enviando insumos, equipamentos e testes para a detecção da doença, ${ }^{10}$ contando com um decreto estadual instaurando situação de emergência, não somente em São Gabriel da Cachoeira, mas em vários municípios do Alto Rio Negro. O fato mostra a atuaçáo estadual em situaçôes sem apelo nacional, como no caso da pandemia, e a inconstância de sua atuação, sem a manutenção de um hospital regional, apesar das diversas endemias.

Com relação à pandemia do coronavírus em 2020, o auxílio estadual se mostrou aquém do esperado. O gráfico 1 mostra uma retração das transferências estaduais (cotas-partes do ICMS e do IPVA) a partir de fevereiro, em decorrência da queda da atividade econômica.

GRÁFICO 1

Transferências do governo estadual para São Gabriel da Cachoeira (2020)

(Em R\$ 1 mil)

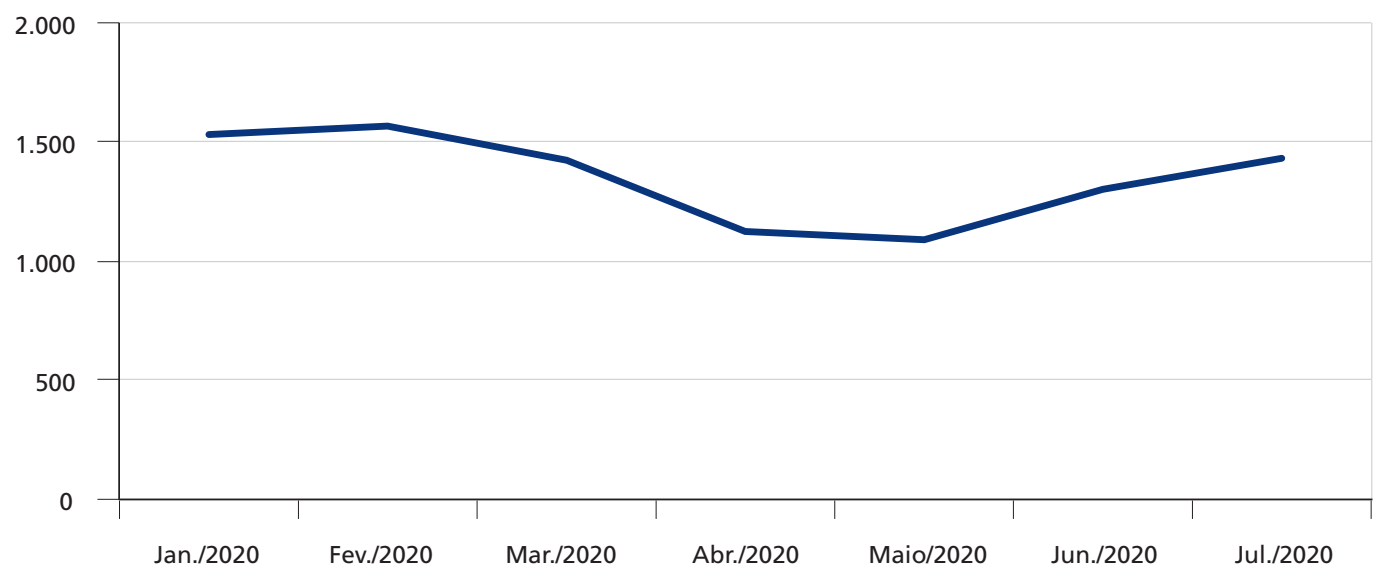

Fonte: Secretaria de Estado da Fazenda (Sefaz) do Amazonas. Disponivel em: <https://bit.ly/31EMBmQ>. Acesso em: 7 ago. 2020.

Ao contrário do auxílio do governo federal, não foram encontradas formas de compensação estadual para evitar quedas na renda e colapsos nos serviços públicos. Náo houve nenhum convênio de saída (quando os recursos saem do Tesouro) até julho de 2020 com São Gabriel da Cachoeira ou com organizaçóes não governamentais (ONGs) que atuam na região e que prestam determinados serviços de natureza pública, como o Instituto Socioambiental (ISA), a Federação das Organizaçôes Indígenas do Rio Negro (Foirn) ou a organização Médicos sem Fronteiras (MSF), seja na área de saúde ou em qualquer outra. ${ }^{11}$ Mesmo a compensação do governo federal a partir da LC no $173 / 2020$ só foi aprovada em final de maio, dois meses após o início da queda nas transferências, o que demonstrou um lapso e uma desarticulação na ação governamental.

Quanto às ações, o estado do Amazonas criou o Comitê Intersetorial de Enfrentamento e Combate à Covid-19, pelo Decreto no 42.061, de 26 de março de 2020, o qual contava somente com instituiçóes estaduais, demonstrando a baixa articulação interinstitucional nesse nível governamental. Uma das iniciativas do comitê foi monitorar e acompanhar os casos nas populaçôes indígenas, ação realizada pela FVS/AM, que já havia trabalhado na região

10. Disponível em: <https://bit.ly/3ivCAPD>. Acesso em: 7 ago. 2020.

11. Disponível em: <https://bit.ly/3ivDaNj>. Acesso em: 6 ago. 2020. 
durante o surto de malária. A figura 1 demonstra que a região de São Gabriel da Cachoeira é a área com mais casos de indígenas infectados pela Covid-19 (2.026) até finais de julho.

FIGURA 1

Distribuição espacial dos casos de Covid-19 entre indígenas

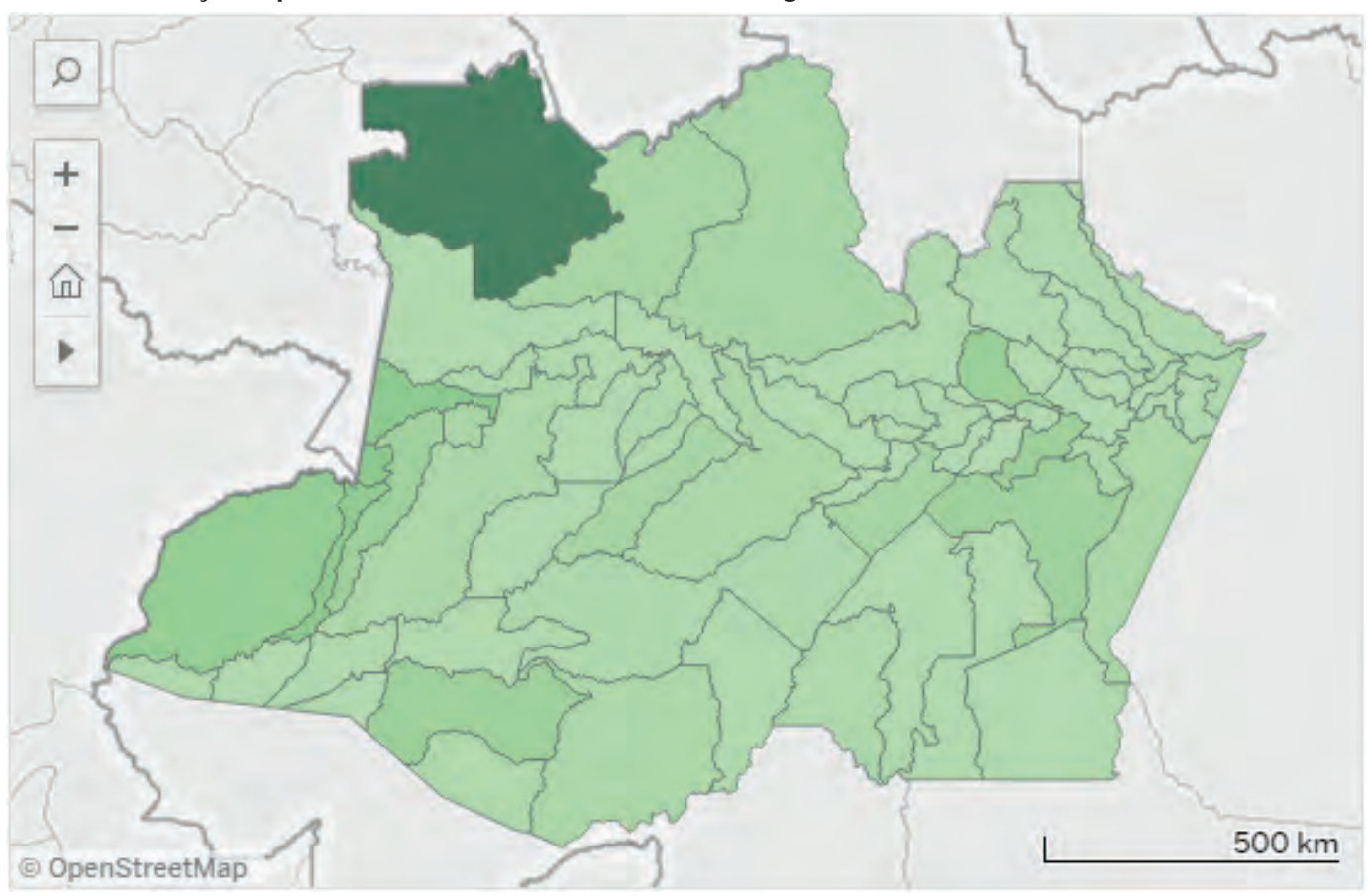

Fonte: FVS/AM. Disponível em: <https://bit.ly/2CmiZ5a>. Acesso em: 10 ago. 2020.

De outra maneira, noticiou-se na imprensa local ${ }^{12}$ a entrega, em maio, de cestas básicas, máscaras e álcool em gel, uma iniciativa conjunta da Funai e do Ministério da Saúde, em certo sentido órgáos acionados além do aparato montado no comitê interinstitucional estadual. Nessa ótica, vale destacar que a ação interministerial de junho do governo federal foi mais contundente, uma vez que levou, além das cestas básicas, instrumentos de assistência à saúde (medicamentos, vacinas e testes rápidos) à região do Alto Rio Negro, em que está incluído o município de São Gabriel.

Diante do exposto, o governo estadual mostrou ações mais frágeis em relação ao enfrentamento da pandemia em Sáo Gabriel da Cachoeira, diferentemente de anos anteriores, em que capitaneou açóes de combate à malária e à dengue. $\mathrm{O}$ estado, por sua vez, não conta com a capacidade de prover auxílio emergencial aos cidadáos e transferências para a manutenção das receitas públicas do governo federal, mas poderia ter atuado anteriormente com a construção de um hospital regional de acordo com a dinâmica territorial indígena. Tal fator pode ser explicado pela centralidade política e de recursos em Manaus, a capital do estado, que também enfrentou sérios problemas durante a pandemia.

No âmbito político, a nota técnica de Moraes, Silva e Toscano, (2020, p. 15) discorre sobre o fato de que o governo estadual baixou um decreto que normatizava a flexibilização e a reabertura das atividades econômicas para o estado - tal decreto, porém, só era válido para a capital, algo diverso dos demais estados, deixando a entender a baixa capilaridade quanto ao seu território. Nos recursos, o Decreto no 28.115/2008 já estabelecia que Manaus

12. Disponível em: <https://bit.ly/31FwZzr>. Acesso em: 11 ago. 2020. 
recebesse mais de $60 \%$ dos recursos de cota-parte do ICMS do estado, um dos maiores percentuais do Brasil, o que demonstra a concentração financeira na capital.

\subsection{Governo municipal}

O governo municipal no federalismo é o ente mais próximo da população e do território e o primeiro a ser demandado por açôes públicas em situaçóes de calamidade. Como visto, as ações dos governos federal e estadual são pontuais, e em relação às finanças públicas não havia grandes expectativas quanto a uma ação financeira mais ativa do município ao enfrentamento da pandemia, uma vez que metade dos recursos foi direcionada à educação. Vale ressaltar que, em janeiro, a prefeitura já havia autorizado um desconto de $30 \%$ - Decreto no 001/2020 - para quem quitasse o Imposto Predial e Territorial Urbano (IPTU) até 10 de abril, criando, ainda, a possibilidade de o contribuinte ter 10\% de desconto se realizasse a quitação até o fim do ano, o que demonstra a fragilidade tributária do município, que já possui uma baixa arrecadaçáo desse imposto e, por conseguinte, uma baixa autonomia de gastos, seja no cotidiano ou em situaçôes excepcionais de pandemia.

Apesar do quadro fiscal, o Executivo municipal tomou medidas de distanciamento social, como a instauração de lockdown em maio (Decreto no 26, de 26 de maio de 2020) após um surto de casos na região, situação que perdurou até junho. De maneira similar, antes do lockdown, o município já havia determinado, pelo Decreto nº 003, de 18 de março de 2020, a criação do Comitê de Enfrentamento e Combate à Covid-19, uma ampla articulação que contava com a participação de todas as secretarias municipais, instituiçôes do governo federal - Forças Armadas, Funai, DSEI -, Câmara Municipal e ONGs como o ISA e a Foirn. Vale destacar que a presença estadual no comitê só se fez presente pelo Ministério Público do estado, pelo Poder Judiciário e pelas polícias Civil e Militar. Não houve participação da Secretaria de Saúde do estado, tampouco do FVS/AM, o que mostrou o distanciamento dessa esfera no combate à pandemia no interior, em especial quanto à questão indígena.

Foi uma resposta, ao mesmo tempo que um pedido de colaboração, para instituições não internas ao corpo estatal, mas que povoam a Amazônia: as ONGs (Camely, 2018). O Executivo municipal catalisou essas forças em um momento de calamidade pública. Segundo relato do Greenpeace, ${ }^{13}$ foram produzidas cartilhas, com o apoio do ISA e do Foirn, nas línguas indígenas locais (baniwa, dâw, hupdá, nheengatu e tukano), para a prevenção ao vírus, assim como realizadas barreiras sanitárias com o apoio do Exército e reunióes na maloca sede da Foirn, conforme demonstrado na figura 2.

Ademais, a articulaçáo interinstitucional possibilitada pelo decreto da prefeitura de São Gabriel da Cachoeira possibilitou a criação de Unidades de Atenção Primária Indígena (Uapis), coordenadas pelo DSEI, do Ministério da Saúde, além de um centro de acolhimento gerido pela ONG MSF.

As ONGs são importantes parceiras, por se localizarem no território de São Gabriel da Cachoeira. O ISA tem uma de suas subsedes no município, além de estar presente em Manaus, Boa Vista (Roraima), Altamira (Pará), Brasília, Canarana (Mato Grosso) e Eldorado e Sáo Paulo (São Paulo), do mesmo modo que o Foirn tem sua sede em São Gabriel.

13. Disponível em: <https://bit.ly/3gMFWNK>. Acesso em: 6 ago. 2020. 
FIGURA 2

São Gabriel da Cachoeira, Amazonas: reunião do Comitê de Enfrentamento e Combate à Covid-19

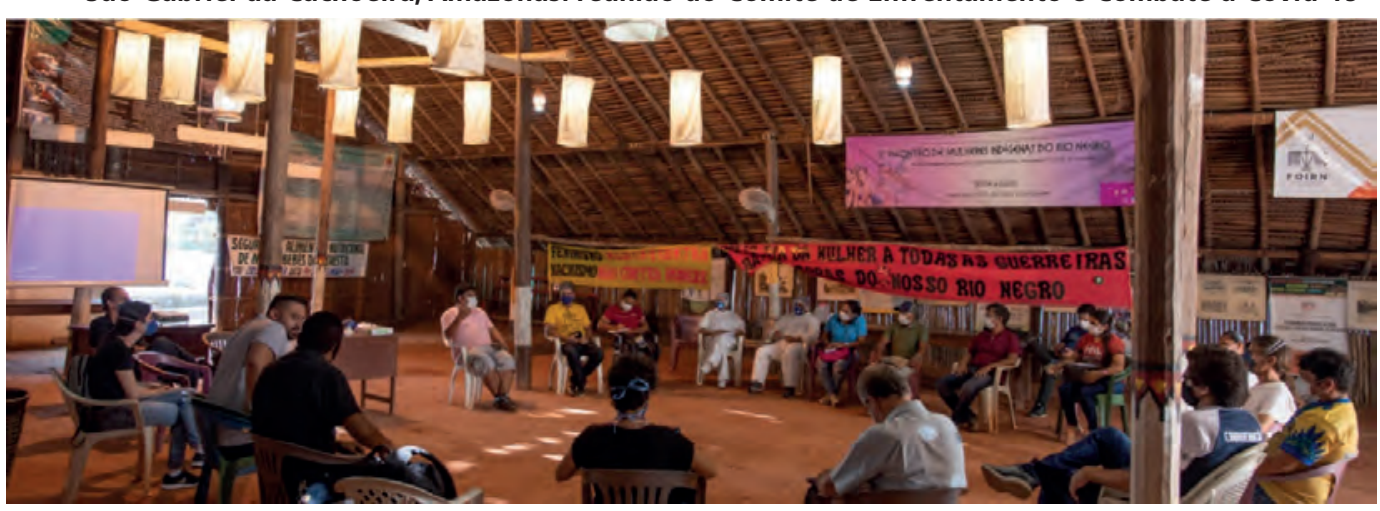

Fonte: Greenpeace. Disponível em: <https://bit.ly/3itOUBR>. Acesso em: 4 ago. 2020

A localização no território traz uma proximidade com a população local, algo que o governo federal só experimenta por meio do Exército e do DSEI. As demais são extraterritoriais, vindas da sede do poder (no caso, Brasília), que duram um curto período e têm um estranhamento, em certa medida, com o cotidiano indígena. $\mathrm{O}$ mesmo sentido pode ser aplicado ao governo estadual, que não consolidou um hospital regional na sede do município e se especializou em açóes pontuais vindas de Manaus, como percebido nas crises da malária e da dengue, já recorrentes no município.

As ONGs têm como fontes de recursos as organizaçóes internacionais, o que adiciona mais uma escala ao enfrentamento governamental da Covid-19. O relatório de 2019 do ISA $^{14}$ mostrou que $80 \%$ dos recursos do instituto são estrangeiros. No entanto, as instituiçôes são de vital importância para dar suporte a diversas açôes nos municípios na Amazônia, estando muito mais presentes em áreas distantes das capitais regionais e nacionais que os governos federal e estadual.

\section{CONSIDERAÇÕES FINAIS}

O ensaio buscou demonstrar a atuação dos níveis governamentais em São Gabriel da Cachoeira no Amazonas, o município com maior percentual de indígenas do Brasil, durante a pandemia do coronavírus no período de fevereiro a agosto de 2020. Amparadas em informaçóes das finanças públicas e em legislaçóes, as conclusóes apontam para uma atuação geral do governo federal, a partir do auxílio emergencial e do socorro aos municípios pela LC nํㅜ 173/2020. Nas demais áreas, age em açóes pontuais, com exceção da presença do Exército, da DSEI e da Funai. Quanto ao nível estadual, não houve uma atuaçáo mais relevante no período, em oposição a crises precedentes, como as da malária e da dengue, além dos elevados casos de tuberculose e hanseníase do município. Entretanto, apesar da expertise adquirida, ainda não foi construído um hospital regional que atenda às peculiaridades indígenas. No nível municipal, o maior percentual da RCL se constitui em transferências do Fundeb, o que direciona os gastos locais, consolidando algumas iniciativas inovadoras, como o professor indígena. Nas demais funçóes públicas, porém, essas iniciativas são limitadas à atuação da prefeitura. Nesse sentido, foi criado o comitê de enfrentamento à Covid-19, que envolvia várias instituiçôes presentes no território, destacando a ausência do Executivo estadual e

14. Disponível em: <https://bit.ly/2XP3biK>. Acesso em: 11 ago. 2020. 
a presença das ONGs com recursos internacionais e com sedes no município, como ISA, Foirn e MSF, que auxiliaram no combate à pandemia.

\section{REFERÊNCIAS}

CAMELY, N. Imperialismo, ambientalismo e ONGs na Amazônia. 1. ed. Rio de Janeiro: Consequência, 2018.

IMBIRIBA, E. B. et al. Hanseníase em populaçôes indígenas do Amazonas, Brasil: um estudo epidemiológico nos municípios de Autazes, Eirunepé e São Gabriel da Cachoeira (2000 a 2005). Caderno de Saúde Pública, Rio de Janeiro, v. 25, n. 5, p. 972-984, 2009.

LEVINO, A.; OLIVEIRA, R. M. Tuberculose na população indígena de São Gabriel da Cachoeira, Amazonas, Brasil. Caderno de Saúde Pública, Rio de Janeiro, v. 23, n. 7, p. 1728-1732, 2007.

MORAES, R. F.; SILVA, L. L.; TOSCANO, C. Covid-19 e medidas de distanciamento social no Brasil: análise comparativa dos planos estaduais de flexibilização. Brasília: Ipea, ago. 2020 (Nota Técnica, n. 25). 


\section{ENSAIOS EM ECONOMIA URBANA}





\title{
A VIABILIDADE DO IMPOSTO SOBRE O VALOR DA TERRA: ANÁLISE TEÓRICA E EMPÍRICA, E SEU CONTEXTO NA REFORMA TRIBUTÁRIA ${ }^{1}$
}

\author{
Claudia M. De Cesare ${ }^{2}$ \\ Cintia Estefania Fernandes ${ }^{3}$ \\ Gelson Santos Oliveira ${ }^{4}$ \\ Pedro Humberto B. Carvalho Junior ${ }^{5}$
}

\section{INTRODUÇÃO}

O relatório da Proposta de Emenda Constitucional (PEC) no 110/2019, cujo objeto é a reformulação do Sistema Tributário Nacional (STN), tem sido discutido em diferentes fóruns e grupos que analisam os encaminhamentos relacionados à reforma tributária. Não obstante as 141 emendas abordadas no relatório, propóem-se alteraçôes adicionais ao projeto de reforma tributária. Entre estas alteraçôes, é recomendado que a base de cálculo do IPTU seja modificada para o valor da terra desconsiderando as construçóes (item xix, p. 28). ${ }^{6}$ É, também, sugerido o estabelecimento, por intermédio de lei complementar, de alíquotas mínimas e máximas para o imposto proposto, limites para a concessão de isençôes e benefícios fiscais, e critérios para a avaliação dos imóveis.

\footnotetext{
1. DOI: http://dx.doi.org/10.38116/brua24art7

2. Pesquisadora e consultora. PhD pela Universidade de Salford, Inglaterra; conselheira do International Property Tax Institute (IPTI); membro do Teaching Faculty do Lincoln Institute of Land Policy; e professora do Programa Nacional de Capacitação das Cidades e da Universidade Federal do Rio Grande do Sul (UFRGS).

3. Procuradora de Curitiba. Doutora em gestão urbana pela Pontifícia Universidade Católica do Paraná (PUCPR); mestra em direito do Estado, direito tributário pela Universidade Federal do Paraná (UFPR); especialista em políticas de solo urbano pelo Lincoln Institute of Land Policy (Massachusetts-Estados Unidos); membro do Teaching Faculty do Lincoln Institute of Land Policy; professora do Programa Nacional de Capacitação das Cidades (Ministério do Desenvolvimento Regional - MDR), do Instituto Brasileiro de Estudos Tributários (IBET), da Academia Brasileira de Direito Constitucional (ABDConst) e do Centro Universitário de Curitiba (UniCuritiba). Presidente da Comissão de Direito à Cidade (Ordem dos Advogados do Brasil do Paraná - OAB/PR) e vice-presidente da Comissão Nacional de Direito Urbanístico da OAB.

4. Auditor fiscal da Secretaria Municipal da Fazenda de Salvador; membro da Coordenação Técnica da Planta Genérica de Valores; ex-gerente de auditoria fiscal do Grupo Especializado de Imposto Predial e Territorial Urbano (IPTU) e conselheiro do Conselho Municipal de Contribuintes; especialista em direito tributário - Fundação Faculdade de Direito (Universidade Federal da Bahia - UFBA); planejamento urbano e gestão de cidades (Universidade Salvador - Unifacs); e professor em cursos e treinamentos em tributação imobiliária.

5. Técnico de planejamento e pesquisa na Diretoria de Estudos e Relações Econômicas e Políticas Internacionais (Dinte) do Ipea. PhD em política tributária pela Universidade de Pretória, África do Sul.

6. Disponível em: <https://legis.senado.leg.br/sdleg-getter/documento?dm=8050102\&ts=1594007105613\&disposition=inline>.
} 
A viabilidade desta proposta, no entanto, deve ser cuidadosamente analisada. Alteraçóes na política tributária devem ser fundamentadas na avaliação dos seus impactos, visando evitar mudanças que reduzam as receitas municipais, colocando em risco a continuidade da prestação de serviços públicos básicos, ou que resultem em regressividade na distribuição da carga tributária para a maior parte dos contribuintes. Em especial, é necessário contar com análises empíricas dedicadas a responder satisfatoriamente as seguintes questôes centrais.

1) No contexto atual, um imposto exclusivamente sobre o valor da terra urbana, desconsiderando as construçóes, poderia apresentar potencial de arrecadação semelhante a um imposto cuja base de cálculo seja o valor integral do imóvel (terra e construçóes)?

2) Em caso positivo, qual seria a alíquota que compensaria a perda de receita produzida pela exclusão das construçóes? Haveria o risco de esta alíquota ser confiscatória para parte dos imóveis? Por sua vez, sem alteração das alíquotas, qual seria a perda na arrecadação?

3) Em comparação ao IPTU, o imposto sobre o valor da terra irá melhorar ou piorar a relaçáo entre o ônus tributário e a capacidade contributiva das famílias? Haverá progressividade ou regressividade na redistribuição da carga tributária?

4) Qual o risco de as unidades de alto padráo localizadas em condomínios verticais pagarem um imposto simbólico?

5) Como seria o impacto do imposto sobre o valor da terra nos segmentos não residenciais (comércio, indústria e serviços)? Lojas e demais estabelecimentos mercantis horizontais sofreriam uma carga tributária desproporcional em comparação com unidades comerciais localizadas em condomínios verticais, como salas e consultórios?

6) O imposto sobre o valor da terra incentivaria a demolição desnecessária de prédios e imóveis que apresentam condiçóes satisfatórias de habitabilidade, visando incentivar que as cidades sejam mais compactas?

7) Considerando o perfil fortemente heterogêneo dos municípios brasileiros, quanto o valor da terra representa em relação ao valor integral do estoque imobiliário nas diferentes cidades e tipos de imóveis?

8) Considerando ainda que a maioria dos municípios nos quais o IPTU é uma receita relevante tem um perfil eminentemente urbano, qual a proporção de terrenos baldios nestas cidades?

9) Em cidades consolidadas, é mais viável estimar com precisão o valor dos imóveis construídos ou o seu valor desconsiderando as construçóes?

10) E quanto ao cadastro imobiliário, o imposto sobre o valor da terra permitiria a exclusão das construçôes para resultar em um sistema mais simplificado?

11) Com relação à legislação vigente, existem mecanismos para combater a especulação imobiliária no Brasil?

Este artigo busca analisar a viabilidade de introduzir um imposto sobre o valor da terra no contexto brasileiro, levando em conta aspectos legais, questóes relativas a sua implementação e benefícios potenciais. $\mathrm{O}$ artigo está dividido em cinco seçôes. Além desta primeira seção introdutória, a segunda seção abrange a revisão da literatura relacionada ao imposto sobre o valor da terra (conhecido como land value taxation). A terceira examina os resultados de análises empíricas sobre a sua aplicabilidade no Brasil, mais especificamente na cidade de Porto Alegre. A quarta seção analisa o atual desempenho dos dois impostos recorrentes 
sobre a propriedade imobiliária: o IPTU e o Imposto sobre a Propriedade Territorial Rural (ITR). Por fim, a quinta seção apresenta as principais conclusôes e recomendações da análise.

\section{IMPOSTO SOBRE O VALOR DA TERRA: FUNDAMENTAÇÃO TEÓRICA}

Economistas clássicos do século XIX, incluindo David Ricardo, reconheceram que o imposto sobre o valor da terra não causa distorçóes econômicas (Netzer, 1998). Com base fundamentalmente nos estudos de John Locke e Henry George, a teoria liberal fornece as principais premissas econômicas para sua fundamentação, que resultam do reconhecimento de que recursos naturais - terra, ar ou água - são bens públicos que pertencem a todos, justificando assim a arrecadação integral da renda que poderia ser extraída destes bens pelo Estado (Plassmann, 1997). Tideman (1999) enfatiza que é o fluxo, em vez do estoque, dos recursos naturais, isto é, a renda extraída destes bens que deve ser alocada igualmente para a comunidade.

No livro Progresso e Pobreza, publicado em 1879, Henry George defende a aplicação de um imposto único sobre o valor da terra a fim de compensar a injustiça causada pela propriedade privada. $\mathrm{O}$ autor explica que a renda da terra pode ser entendida como uma fonte de enriquecimento sem causa, visto que não é uma consequência de açóes realizadas pelos seus proprietários. Inspirados pelas ideias de Henry George, nove economistas foram agraciados com o Prêmio Nobel em economia. ${ }^{7}$

Do ponto de vista econômico, a tributação sobre o valor da terra desconsiderando as construções é enaltecida pelo fato de que este imposto não distorce decisôes econômicas em razão de a oferta da terra ser fixa (Brueckner, 1986). Em contraste, decisóes sobre investimentos em construção ou equipamentos podem variar devido a maior ou menor incidência tributária. Como observam De Cesare et al. (2003), a terra apresenta as seguintes particularidades:

- é um recurso natural inesgotável que não deprecia com o tempo;

- devido a sua imobilidade, a demanda excessiva em certa localização não pode ser compensada pelo seu excesso em outra área;

- em virtude de sua visibilidade, é um bem que não pode ser omitido, embora a existência de um cadastro territorial atualizado possa ser um grande desafio; e

- é um insumo primordial para a satisfação de necessidades básicas de moradia e trabalho.

Seu valor é determinado exclusivamente pela demanda local, embora seja influenciado por fatores externos, tais como mudanças demográficas, crescimento econômico, política de crédito habitacional e nível de investimento internacional. Para George (1996), o valor da terra é fundamentalmente resultante de esforços coletivos, como gastos públicos em infraestrutura urbana e serviços básicos que "tendem a aumentar dramaticamente o valor dos imóveis beneficiados" (Lichfield e Connellan, 1997). Além disso, o valor da terra está relacionado ao seu potencial construtivo.

O quadro 1 classifica em três grupos os principais argumentos citados na literatura para justificar a instituição do imposto sobre o valor da terra.

7. Paul Samuelson (1970); Milton Friedman Nobel (1976); Herbert Simon (1978); James Tobin (1981); Franco Modigliani (1985); James Buchanan (1986); Robert Solow (1987); William Vickrey (1996); e Joseph Stiglitz (2001). 
QUADRO 1

Argumentos em favor do imposto sobre o valor da terra

\begin{tabular}{|c|c|}
\hline \multirow{2}{*}{ Grupo 1: éticos e filosóficos } & - Igualdade de direitos sobre recursos naturais \\
\hline & - Oportunidade para a captura de valor \\
\hline \multirow{6}{*}{ Grupo 2: econômicos } & - Neutralidade em termos de eficiência econômica' ${ }^{1}$ \\
\hline & - Inexistência de perdas de eficiência (peso-morto)² \\
\hline & - Estímulo ao investimento ${ }^{3}$ \\
\hline & - Redução dos custos da cidade (cidades compactas) \\
\hline & - Incidência econômica progressiva (imposto é pago pelo dono da terra) ${ }^{4}$ \\
\hline & - Melhor alocação da terra \\
\hline \multirow{3}{*}{ Grupo 3: administrativos } & - Simplificação do cadastro \\
\hline & - Impossibilidade de evasão tributária \\
\hline & - Menor custo para a avaliação dos imóveis \\
\hline
\end{tabular}

Fonte: De Cesare et al. (2003).

Notas: ${ }^{1}$ A neutralidade do imposto sobre o valor da terra é relacionada ao fato de o imposto não alterar decisões quanto à intensidade de densificação ou momento de desenvolvimento das áreas. Em outras palavras, decisões consideradas ótimas antes da aplicação do imposto permanecem ótimas após a sua instituição.

${ }^{2}$ Tendem a ser observadas perdas de eficiência (peso-morto) em impostos que incidem sobre bens de oferta elástica, uma vez que o imposto aumenta o valor de mercado do bem, desincentivando o consumo.

${ }^{3}$ Autores da escola neoclássica como Bentick (1979), Mills (1998) e Oates e Schwab (1997) argumentam que o imposto sobre a terra não estimula o investimento, porque o valor da terra no presente já é dado pelo seu "maior e melhor uso".

${ }^{4}$ A teoria econômica demonstra que, quando um imposto é tributado em um bem de oferta constante, independentemente do seu preço, a carga tributária é paga pelo proprietário do bem, que é incapaz de transferir o imposto aos usuários por intermédio da redução da sua oferta.

No entanto, Netzer (1998) alerta que o sucesso político da teoria de Henry George é extremamente limitado. Apesar de o imposto recorrente sobre bens imóveis existir na grande maioria dos países, apenas a Dinamarca, a Austrália e a Estônia estabeleceram um imposto puro ao valor da terra (Pinto, 2020). No caso da Austrália, o imposto imobiliário estadual incide apenas sobre o valor da terra, enquanto o imposto municipal incide sobre o valor integral dos imóveis. ${ }^{8}$ A Jamaica também introduziu o imposto sobre o valor da terra a fim de motivar a reforma agrária. Possivelmente, devem existir outros países pequenos que optaram por essa alternativa. Na Nova Zelândia, a sua reduzida aceitabilidade resultou na inclusão do valor das construçóes em 1992. Ainda, é importante notar que tanto a Austrália como a Nova Zelândia são países de baixa densidade demográfica. Nos Estados Unidos, a grande maioria dos municípios emprega o valor integral do imóvel, incluindo as construçóes, exceto em municípios do estado da Pensilvânia.

Cabe a reflexáo sobre quais os fatores que explicam o alto grau de rejeição do imposto sobre o valor da terra no âmbito mundial. Obstáculos à sua implementaçáo e falta de evidências empíricas dos argumentos apresentados no quadro 1 são discutidos na sequência.

\subsection{Falta de comprovação empírica sobre os efeitos econômicos}

As evidências empíricas sobre os efeitos de excluir o valor das construçóes do imposto imobiliário na atividade de construção são limitadas. Estudos realizados entre 1980 e 2000 apresentam resultados contraditórios. ${ }^{9}$ Como enfatizado por Plassmann (1997), não há resultados consistentes que indiquem alteraçôes nas decisôes relacionadas à atividade da construção.

8. Disponível em: <http://www1.worldbank.org/publicsector/decentralization/June2003Seminar/Australia.pdf>.

9. São eles: Edwards (1984); Mathis e Zech (1982); Weir e Peters (1986); Lusht (1992); Tideman e Johnson (1995); Oates e Schwab (1997); e Plassmann (1997). Lusht (1992) e Plassmann (1997) conseguiram identificar um impacto positivo do imposto na atividade de construção. 


\subsection{Efeitos controversos}

Andelson (2000) alerta sobre o risco de superdensificação urbana como efeito controverso desta política. Atualmente, as preocupações com densificação populacional excessiva estão em pauta em consequência do risco de proliferação de doenças contagiosas, entre as quais merece destaque a Covid-19.

Com base no posicionamento de diferentes urbanistas americanos, Flint (2020) alerta para transformaçôes urbanas prováveis no período pós-pandemia, abrangendo: aumento de espaços abertos nos imóveis; introdução de melhores sistemas de ventilaçáo; viabilização de divisôes flexíveis que permitam maior privacidade; reduçáo no número de trabalhadores nos imóveis não residenciais em função do trabalho remoto; e revalorização da vida nos subúrbios onde as famílias podem desfrutar de mais espaço. No Brasil, com a intensificação do trabalho remoto, observou-se a transferência de muitas famílias dos seus apartamentos com espaço limitado nas cidades para casas de veraneio nos balneários ou na serra nos segmentos de renda média-alta e alta. Embora ainda seja cedo para assegurar quais as transformaçôes urbanas terão caráter mais permanente, a tendência é que o enfrentamento traumático da Covid-19 motive a redução da densificação das áreas urbanas, desafiando a máxima de que as cidades devem ser compactas.

\subsection{Desvinculação da capacidade contributiva e risco de perda de receita}

McCluskey e Williams (1999) advertem que um imposto sobre o valor da terra limita significativamente a magnitude da base de cálculo, excluindo parte substancial da riqueza, principalmente em cidades urbanas consolidadas. Embora a perda de receita possa ser compensada pela elevação da alíquota, é imprescindível assegurar a existência de capacidade contributiva para arcar com o ônus tributário nas diferentes classes de imóveis devido à desvinculação entre o imposto e a riqueza. Em virtude da necessidade de renda monetária líquida para o pagamento do imposto, a inadimplência tende a aumentar quando a base de cálculo é desvinculada da renda do contribuinte (UN-Habitat, 2011), como ocorre com o imposto sobre o valor da terra.

\subsection{Receio de confisco e pressões políticas}

Andelson (2000) alerta que impostos com alíquotas elevadas sobre a terra tendem a ser vistos como confiscatórios, com base no argumento de que a terra foi adquirida de boa-fé e que a legislação garante os direitos de propriedade. Plassmann (1997) reconhece que o imposto pode criar injustiças e resultar em fortes pressôes políticas.

\subsection{Falácia nos argumentos de cunho administrativo}

Os argumentos sobre a redução do custo administrativo em apoio ao imposto sobre o valor da terra são questionáveis. Por exemplo, a afirmaçáo de que é impossível a ocorrência de evasão tributária não é verdadeira para cidades marcadas por assentamentos informais e parcelamentos irregulares. Em termos tributários, a maior dificuldade nestes casos consiste em identificar o contribuinte. Este desafio permanece inalterado independentemente de a base de cálculo do tributo ser o valor integral do imóvel ou o valor da terra desconsiderando as construçóes.

A hipótese de simplificação do cadastro deve também ser descartada. O poder público necessita monitorar o estoque imobiliário e seu crescimento para fins de planejamento territorial, instituição de instrumentos de política urbana e fiscalização das declaraçôes do 
imposto sobre as transferências de imóveis. A exclusão das construçôes das bases cadastrais seria um retrocesso, podendo ser até inviável sem a realização de um recadastramento completo dos imóveis, o que aumentaria o custo de transição do modelo.

A redução no custo das avaliaçóes seria parcial. Por exemplo, os observatórios do mercado imobiliário ${ }^{10}$ necessitam ser mantidos para viabilizar a aplicação do método residual na avaliação dos terrenos; ${ }^{11}$ servir de base em avaliaçóes desenvolvidas para fins de Imposto sobre a Transmissão de Bens Imóveis (ITBI), desapropriaçôes e concessóes de uso; e embasar decisões de políticas urbanas. Cabe ainda notar que a avaliação de terrenos em cidades urbanas consolidadas é mais difícil que a avaliação de bens cuja oferta é abundante no mercado de imóveis.

\subsection{Iniquidades de caráter avaliatório}

Observa-se forte consenso quanto à dificuldade de avaliar com precisão o valor da terra excluindo as edificaçóes (Lichfield e Connellan, 1997; McCluskey e Franzsen, 1999). Conforme Arnott (2000, p. 25, tradução nossa), "não há formas consistentes de decompor o valor de um imóvel em terra e benfeitorias”. O argumento é especialmente verdadeiro para cidades urbanas consolidadas onde inexistem terrenos baldios em regiốes centrais, polos comerciais e outras áreas fortemente densificadas. Segundo Mills (1998), regras arbitrárias tendem a ser utilizadas, resultando em iniquidades de caráter avaliatório que prejudicam inclusive a eficiência econômica do imposto ao valor da terra.

\subsection{Falta de transparência, arbitrariedade e prejuízo ao direito de contestação}

Quanto aos imóveis edificados, os contribuintes conhecem ou têm condições de conhecer o preço dos seus imóveis. No imposto sobre o valor da terra, o exercício dos direitos à contestação por parte dos contribuintes de imóveis edificados fica prejudicado nas vias administrativas ou judiciais, devido à ausência de informação sobre preços da terra em imóveis construídos.

\subsection{Percepção de regressividade}

O imposto sobre o valor da terra tende a ser percebido como injusto pelos contribuintes. Como observa Reece (1992), existe iniquidade entre quem possui bens de valor semelhante, bem como tende a beneficiar contribuintes que possuem maior capacidade contributiva. A seguir encontram-se alguns exemplos ilustrativos de situaçôes relacionadas à percepção de injustiça.

- A depreciação das construções é ignorada no cálculo do imposto sobre o valor da terra. Portanto, o proprietário de um apartamento novo pagaria imposto idêntico ao dono de um apartamento antigo em mesma localização.

- Os impostos lançados para dois prédios de mesma área de terreno, situados na mesma face de quarteirão, são iguais, independentemente do número de pavimentos em cada um deles. Desta forma, imóveis antigos, com poucos andares, e de baixo valor, pagariam imposto significativamente maior que imóveis novos, de padrão superior, que estejam localizados em prédio com muitos andares.

10. Sistema de informação destinado à coleta e ao armazenamento contínuo de dados de mercado, incluindo preços de oferta e venda de imóveis, cujo propósito é monitorar o mercado imobiliário e fornecer os dados necessários para a aplicação de diferentes métodos de avaliação de imóveis.

11. Metodologia de estimação do valor da terra de um imóvel construído, que consiste em extrair o custo da edificação e todas as benfeitorias do valor de mercado do imóvel, resultando, como resíduo, no valor da terra. 
As situaçóes citadas ilustram a perda de conexão entre o imposto e a capacidade contributiva. Por razóes que fogem ao escopo deste artigo, ${ }^{12}$ as cidades brasileiras consolidadas apresentam um perfil de ocupação altamente heterogêneo. A figura 1 mostra casos de condomínios verticais situados na mesma rua na cidade de Porto Alegre. A aplicaçáo do imposto sobre o valor da terra desconsiderando as construçóes resultaria em forte regressividade principalmente para unidades em condomínios verticais, onerando apartamentos pequenos e antigos.

FIGURA 1

Prédios próximos de características heterogêneas no bairro Menino Deus em Porto Alegre

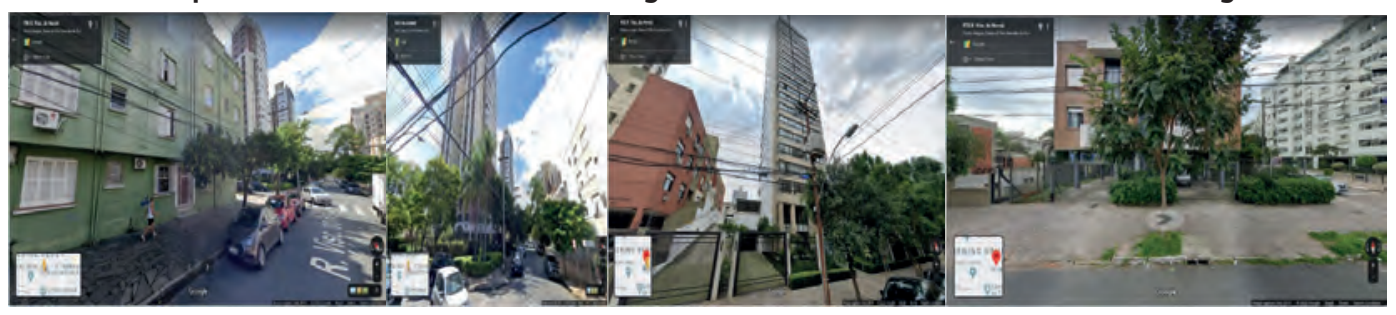

Elaboração dos autores.

\section{DISTRIBUIÇÃO DA CARGA TRIBUTÁRIA}

Além de avaliar o impacto do imposto sobre o valor da terra na atividade de construção, a viabilidade da sua instituição depende da redistribuição da carga tributária nos diferentes segmentos de imóveis. Esta análise é particularmente relevante no caso de municípios altamente densificados, nos quais grande parte da população mora ou trabalha em prédios em condomínios verticais.

O único estudo a respeito da distribuição da carga tributária de um eventual imposto sobre o valor da terra no Brasil foi desenvolvido por De Cesare et al. (2003). Este estudo analisa o impacto da mudança da base de cálculo do IPTU para o valor da terra para imóveis residenciais na cidade de Porto Alegre.

Uma das premissas para realizar a análise foi assumir que a transição deveria ser neutra, isto é, não haveria nem perda nem incremento de receita no lançamento global do imposto. O estudo contemplou duas situaçóes: i) receita a ser aferida pelo imposto sobre o valor da terra baseada nas avaliaçóes imobiliárias vigentes; e ii) receita a ser aferida caso imóveis fossem avaliados pelo valor de mercado (perfeita administração tributária). Os resultados desta análise empírica são mostrados na tabela 1 .

Em comparação com o sistema vigente, caracterizado por subavaliaçóes, o valor médio cobrado sobre imóveis de menor valor (primeiro quartil) aumentaria $76 \%$ e sobre imóveis de alto valor (quarto quartil) seria reduzido em 16\%. Com avaliaçóes em nível de mercado, o valor médio cobrado sobre imóveis de baixo valor seria reduzido em 19\% e sobre imóveis de alto valor seria aumentado em $9 \%$.

12. 0 regramento urbanístico muda com frequência. Por exemplo, prédios de quatro pavimentos sem elevador construídos nos anos 1980 compartilham o espaço urbano com prédios novos de quinze ou mais pavimentos nos quais os condôminos desfrutam de áreas de lazer e vários espaços de estacionamento. 
TABELA 1

Alteração média do valor cobrado com a substituição do IPTU por um imposto sobre o valor da terra em Porto Alegre, por classe de imóvel (2003)

(Em \%)

\begin{tabular}{|c|c|c|c|c|c|c|}
\hline \multirow{2}{*}{$\begin{array}{l}\text { Quartil de valor } \\
\text { de imóvel }\end{array}$} & \multicolumn{3}{|c|}{ Sistema vigente } & \multicolumn{3}{|c|}{ Perfeita administração tributária } \\
\hline & Global & Casa & Apartamento & Global & Casa & Apartamento \\
\hline Primeiro & +76 & +260 & +64 & -19 & +160 & -33 \\
\hline Segundo e terceiro & +36 & +58 & -4 & -9 & +70 & -49 \\
\hline Quarto & -16 & +11 & -55 & +9 & +70 & -51 \\
\hline Total & 0 & +39 & -38 & 0 & +78 & -49 \\
\hline
\end{tabular}

Fonte: De Cesare et al. (2003)

Elaboração dos autores.

No entanto, considerando-se apenas as casas, com o sistema vigente, o imposto médio cobrado aumentaria em $39 \%$, sendo $260 \%$ para casas de baixo valor, enquanto os apartamentos teriam uma redução de $38 \%$. Com avaliaçôes a valores de mercado, o imposto médio das casas aumentaria em $78 \%$, sendo $160 \%$ para casas de baixo valor, e o dos apartamentos seria reduzido em $49 \%$.

Ainda pelo estudo de De Cesare et al. (2003), em relação ao padrão construtivo, com as avaliações vigentes, reduçôes tributárias significativas seriam observadas em imóveis classificados como luxo (-75\%) e fino (-35\%). A perda desta arrecadação seria compensada por aumentos exorbitantes no valor do imposto para construçôes de padrão precário (+417\%), de alvenaria mista $(+375 \%)$ e de madeira $(+628 \%)$.

Em função do baixo nível de avaliação dos imóveis de Porto Alegre na época do estudo, foi mais adequado verificar a alíquota necessária para a instituiçâo de um imposto sobre o valor da terra considerando as avaliaçóes a preços de mercado. Neste caso, seria necessária uma alíquota de 3\% (3,5 vezes superior à alíquota original) para compensar a exclusão do valor das construçôes.

Os dados disponibilizados pelo Lincoln Institute of Land Policy (tabela V-3) ${ }^{13}$ e por Carvalho Junior (2017, p. 230) indicam que os terrenos baldios representam pequeno percentual dos imóveis cadastrados em cidades consolidadas, entre 3\% e 12\% em Aracaju, Belo Horizonte, Brasília, Curitiba, Florianópolis, Fortaleza, Porto Alegre, Recife, Rio de Janeiro, Salvador e São Paulo. No caso de elevado nível de desatualização cadastral, esses indicadores podem ainda estar superestimados, visto que parte das áreas cadastradas como terrenos pode ter sido informalmente loteada, construída e ocupada. Em municípios menores com baixa densidade populacional, o número de terrenos baldios tende a ser maior.

\section{ANÁLISE DO DESEMPENHO DOS TRIBUTOS IMOBILIÁRIOS RECORRENTES}

\subsection{IPTU}

O IPTU é um tributo direto, cujo perfil é estritamente local. Visando fortalecer o interesse local e a justiça social imobiliária, os municípios brasileiros são entes federativos que gozam de autonomia fiscal nos termos constitucionais. Desta forma, alíquotas, isenções e outros benefícios fiscais do IPTU são estabelecidos por lei municipal. A magnitude das alíquotas é decorrente da negociação entre governo municipal e seus munícipes sobre a abrangência

13. Disponível em: <https://www.lincolninst.edu/research-data/data/property-tax-latin-america>. 
e a qualidade dos serviços públicos prestados e a capacidade contributiva dos contribuintes. As alíquotas servem, também, para a consecução de objetivos extrafiscais, juntamente com as isenções tributárias e incentivos fiscais.

Com base nas premissas constitucionais, sua estrutura visa inconfundivelmente proporcionar que as famílias mais ricas contribuam mais com o financiamento das despesas públicas realizadas no âmbito local. Isto é decorrente da sua base de cálculo, que é o valor de mercado dos imóveis, incluindo terra e construçôes, bem como da viabilidade de aplicar alíquotas progressivas em razão do valor do imóvel nos termos do art. 156, $\$ 1$, inciso I, da Constituição Federal de 1988 (CF/1988).

Em contrapartida, o IPTU viabiliza a integração entre políticas públicas, fiscais e urbanas. Com o objetivo de promover o uso racional da terra, reduzir a sua ociosidade e desestimular a especulação imobiliária, é viável instituir tanto alíquotas mais elevadas aos terrenos baldios quanto progressivas no tempo, visando ao cumprimento da função social e ambiental da propriedade nos termos do art. $182, \mathbb{\$} 4^{\circ}$, da CF/1988, e do art. 7o, seção III, do Estatuto da Cidade (Lei no $10.257 / 2001$ ).

A receita proveniente desse instrumento é uma fonte importante de recursos para financiamento dos serviços urbanos de forma sustentável. Quanto maior o grau de urbanizaçáo de uma cidade, maior tende a ser o seu potencial de arrecadação. Nesta crise econômica, sem precedentes, produzida pela Covid-19, a arrecadação de impostos menos sensíveis a choques econômicos, como o IPTU, é preponderante para garantir a manutenção de serviços públicos essenciais.

A arrecadação do IPTU teve aumento real de $50 \%{ }^{14}$ entre 2010 e 2019, representando mais de $30 \%$ da receita de impostos municipais e $0,65 \%$ do produto interno bruto (PIB) brasileiro, cifra inclusive um pouco superior à arrecadação do Imposto sobre a Propriedade de Veículos Automotores (IPVA). Este crescimento demonstra o esforço fiscal de um número significativo de municípios na contratação de levantamentos em massa para atualização do cadastro territorial; criação de observatórios do mercado imobiliário; aprimoramento das rotinas internas de atualização contínua do cadastro territorial; reavaliação dos imóveis; e aperfeiçoamento dos sistemas de arrecadação e cobrança do imposto, inclusive apostando na conscientização dos contribuintes por intermédio de programas de educação fiscal.

Não obstante a melhoria observada na última década, análises empíricas relativamente recentes, aplicando métodos distintos, estimam que o potencial de arrecadação do IPTU pode atingir entre 0,90\% e 1,25\% do PIB no Brasil (Carvalho Junior, 2017; De Cesare et al., 2014; Norregard, 2013; Orair e Albuquerque, 2017). Os seguintes aspectos prejudicam o desempenho do IPTU no Brasil.

\subsubsection{Interferência do Poder Legislativo na atualização da base de cálculo do imposto}

A Súmula no 160/1996 do Superior Tribunal de Justiça (STJ) determina que atualizaçôes da base de cálculo do IPTU em percentual superior ao índice oficial de correção monetária necessitam ser realizadas por lei municipal. O IPTU é o único tributo brasileiro cuja aferiçáo da base de cálculo precisa de sanção do Poder Legislativo.

14. Valor da receita do IPTU principal de 2010 indexado pelo Índice Nacional de Preços ao Consumidor Amplo (IPCA), e considerando a receita do IPTU principal de 2019 como 84\% da arrecadação da soma do principal, multas e dívida ativa, conforme a mudança contábil a partir de 2018. 
Além de desrespeitar preceitos constitucionais e legais, a Súmula expóe os gestores públicos a pressóes políticas de grande magnitude para atualizar a base de cálculo do IPTU. A sua desatualização produz injustiça fiscal e contraria o interesse coletivo, ferindo inclusive os princípios da isonomia e da capacidade contributiva contidos na Carta Magna. Enquanto algumas zonas da cidade ou tipos de imóveis valorizam, outras zonas ou tipos de imóveis depreciam. A manutenção de avaliaçôes desatualizadas faz com que uma parcela dos imóveis pague mais do que deveria, prejudicando tipicamente imóveis que desvalorizaram e áreas nas quais não houve investimentos públicos. Em contraste, esta política tende a beneficiar os imóveis que valorizaram no período.

\subsubsection{Falta de regulamentação de prazos máximos entre avaliações para fins de IPTU}

Ciclos máximos entre a reavaliação de imóveis são exigidos por lei não apenas em países desenvolvidos, mas também na África do Sul, Argentina, Chile, Colômbia, Costa Rica, Equador, Guatemala e Uruguai. Em geral, os prazos máximos estabelecidos variam entre dois e cinco anos.

Além de ser imprescindível para a equidade avaliatória, a regulamentação de ciclos entre as avaliaçóes para fins de IPTU contribuiria para minimizar as pressóes sobre os gestores públicos municipais. A inexistência de um dispositivo legal sobre o tema no Brasil resulta em largos períodos entre as avaliaçóes genéricas. Conforme De Cesare (2018a), em 2017, os ciclos avaliatórios do IPTU superavam dez anos em Vitória, São Luiz, Rio Branco, Porto Velho, Teresina, Natal, Belém, Maceió, Porto Alegre e João Pessoa. Além disso, mesmo os que atualizaram em período recente, a maioria estava sem reavaliar por longo período: Curitiba (10 anos), Aracaju e Salvador (16 anos), Rio de Janeiro (20 anos), Recife (24 anos), e Manaus e Porto Alegre (28 anos). Em um caso extremo, João Pessoa está há mais de 40 anos sem promover a atualização completa no valor estimado dos imóveis. Em âmbito federal, houve inclusive a votaçáo do Projeto de Lei do Senado (PLS) no 277/2014 ${ }^{15}$ para alterar a Lei de Responsabilidade Fiscal e tornar obrigatória a atualização das Plantas Genéricas de Valores a cada quatro anos. Porém, como um projeto de lei complementar necessita de quórum qualificado para sua aprovação (41 votos dos senadores e 257 votos dos deputados), ele foi rejeitado já no plenário do Senado Federal por 40 votos favoráveis e 16 contrários em 2015.

\subsection{ITR}

A União tem competência quanto à tributação recorrente da terra rural. Entretanto, a Emenda Constitucional no 42/2003 autorizou o governo federal a transferir por intermédio de acordo a fiscalização e cobrança do ITR aos municípios que assim optarem (art. 153, $\$ 4^{\circ}$, inciso III, da CF/1988). Não é possível, entretanto, alterar os dispositivos legais constantes na Lei Federal no 9.393/1996, tais como as alíquotas, a forma de lançamento do imposto ou os casos de isenção e não incidência. Segundo o então Ministério da Fazenda (Brasil, 2017), aproximadamente 2.100 municípios possuem convênio para fiscalizar e cobrar o ITR.

A arrecadação do ITR representa apenas entre $0,01 \%$ e $0,02 \%$ do PIB. Sua participação na carga tributária é irrisória e vem sendo reduzida de 0,08\% (1999) para 0,06\% (2019). A legislação vigente é obsoleta. De Cesare (2018b) explica que, sem qualquer indício comprovado de eficácia, o ITR foi estruturado com a finalidade essencialmente extrafiscal de promover o aproveitamento eficiente da terra rural (art. 153, $\$ 4^{\circ}$, inciso I, da CF/1988). A base de cálculo é o valor da terra nua (VTN) tributável, desconsiderando as benfeitorias, estabelecido por autoavaliação (art. 8o e art. 10, da Lei Federal no 9.393/1996). A apuração

15. Disponível em: <https://www25.senado.leg.br/web/atividade/materias/-/materia/118636>. 
e o pagamento do ITR são efetuados pelo contribuinte, sujeitos a eventual homologação, por parte do Fisco, posterior ao recolhimento do imposto. Além de a base de cálculo excluir o valor de construçóes, culturas, pastagens e florestas plantadas, as áreas não tributáveis abrangem um amplo número de situaçôes. ${ }^{16}$ Há ainda uma série de condiçôes de isenção e casos de não incidência tributária.

As alíquotas crescem em função da área dos imóveis e do seu grau de subutilização (art. 153, $\$ 4^{\circ}$, da $\mathrm{CF} / 1988$ ), atributos que sáo declarados pelo contribuinte. Considerando que quase todos os contribuintes declarem que suas propriedades têm um grau de utilizaçáo igual ou superior a $80 \%$ e a maioria das propriedades tenha área tributável até 5 mil hectares, as alíquotas de fato se situam entre $0,03 \%$ e $0,3 \%$. A menor alíquota $(0,03 \%)$ é aplicada a imóveis rurais até 50 ha com grau de utilização superior a $80 \%$, corresponde praticamente à isenção e concentra a maioria das declaraçóes. Desta forma, o ITR se torna o "imposto de dez reais" para muitos, que é o valor mínimo legal do lançamento. ${ }^{17}$ Em contraste, a alíquota máxima, que corresponde a 20\% (área acima de 5 mil hectares e grau de utilizaçáo inferior a 30\%), seria confiscatória se fosse efetivamente aplicada. Entretanto, casos da sua aplicação são desconhecidos.

Além disso, é indiscutível a forte heterogeneidade no perfil das áreas rurais no país. Conforme dados do Instituto Brasileiro de Geografia e Estatística (IBGE), a área média de regiôes de agricultura familiar é entre 5,5 ha e 10 ha no Distrito Federal, Alagoas, Pernambuco e Sergipe; e superior a 50 ha nos estados de Mato Grosso, Tocantins, Pará e Acre. Similarmente, é acentuada a variabilidade no tamanho médio dos estabelecimentos classificados na categoria não familiar, cuja média varia de 75 ha (Sergipe) até 1.600 ha (Mato Grosso). Estas diferenças dificultam o estabelecimento de regramento único para o país.

Conforme alerta Carvalho Junior (2018), em estados com crescimento do setor do agronegócio e do comércio de terras rurais, a arrecadação do ITBI - que abrange imóveis urbanos e rurais - é superior à receita do IPTU em: 60\% dos municípios localizados nos estados de Rondônia, Tocantins, Maranhão, Alagoas, Paraná, Mato Grosso do Sul, Mato Grosso e Goiás; 77\% dos municípios localizados no estado de Mato Grosso; e 85\% dos municípios do estado do Tocantins. Isto demonstra que limitar a competência tributária municipal aos imóveis urbanos pode prejudicar a capacidade de geraçáo de receita própria de municípios com características rurais.

Cabe ainda enfatizar que a gestão administrativa do ITR por parte da União é deficiente. O descaso pode estar relacionado ao acesso a outras fontes de receita mais rentáveis e fáceis de administrar. Farias, Silva e Leite (2018) sugerem que o desempenho insatisfatório do ITR está relacionado à falta de fiscalização, decorrente da distância entre contribuintes e o Fisco, resultando na subdeclaração das áreas tributáveis e na superdeclaração do grau de utilização da área, bem como na impunidade decorrente da ausência de fiscalização e descaso na cobrança das dívidas. ${ }^{18}$

A quase ausência de tributação sobre os imóveis rurais representa um grande desperdício da base tributável. Além disto, a segmentação da tributação recorrente imobiliária em dois níveis distintos de governo produz as seguintes disfuncionalidades: i) duplicidades de

16. Incluem: i) áreas de preservação permanente; ii) reservas legais; iii) reservas particulares do patrimônio natural (RPPN); iv) áreas de interesse ecológico; v) servidões ambientais; vi) florestas nativas, primárias ou secundárias em estágio médio ou avançado de regeneração; e vii) áreas alagadas para fins de constituição de reservatório de usinas hidrelétricas.

17. Disponível em: <https://sistemafaeg.com.br/faeg/noticias/agua/receita-quer-aumentar-arrecadacao-do-itr> .

18. A arrecadação do ITR foi de R\$1,303 bilhão em 2015. Entretanto, com base em dados da Procuradoria-Geral da Fazenda Nacional, os autores revelam que aproximadamente 20 mil contribuintes acumulavam uma dívida de ITR de $R \$ 20,80$ bilhões (em média, R\$ 1 milhão por contribuinte). 
esforço fiscal; ii) desperdício de dinheiro público para manutenção de duas bases territoriais distintas (cadastro urbano e cadastro rural); iii) disputas judiciais sobre a classificação da propriedade; e iv) perda do controle pleno municipal sobre o ordenamento territorial, que é de competência exclusiva dos municípios.

\section{CONCLUSÕES E RECOMENDAÇÕES}

Por ser menos sujeito ao impacto de flutuaçôes econômicas, o IPTU é um imposto essencial para manutenção de serviços básicos das cidades. Náo obstante o seu potencial de melhoria, sua importância como fonte de receita cresceu 50\% nos últimos dez anos, resultante exclusivamente de esforço administrativo de diversos municípios. Como explicado anteriormente, o IPTU está inconfundivelmente estruturado para proporcionar que as famílias e indivíduos mais ricos contribuam mais com o financiamento das despesas públicas realizadas no âmbito local.

A luta dos municípios brasileiros para um IPTU vigoroso, em termos tributários, sociais e urbanísticos, foi conquistada paulatinamente. Por exemplo, as restrições impostas pela Súmula no 668 do Supremo Tribunal Federal (STF) que impediam a aplicação de alíquotas progressivas em razão do valor dos imóveis foram superadas pela Emenda Constitucional no 29/2000, que reconheceu constitucionalmente a viabilidade de vincular o IPTU ao princípio da capacidade contributiva, possibilitando a progressividade, a redistribuiçáo de riquezas, a observância do princípio da solidariedade e da realizaçáo do Estado Social Democrático de Direito (Fernandes, 2005).

As alteraçôes tributárias da PEC no 110/2019 abrangem a substituição do IPTU por um imposto sobre o valor da terra e restringem a competência tributária municipal. Na prática, a maioria dos sistemas no âmbito internacional inclui o valor das construçôes na tributação dos imóveis. Os seguintes aspectos podem justificar a resistência a desconsiderar o valor das construçôes na base de cálculo do imposto sobre bens imóveis:

- análises empíricas sobre os seus efeitos na atividade de construção apresentam resultados contraditórios;

- insegurança se a perda de receita gerada pela exclusáo do valor das construçóes pode ser compensada pelo aumento na alíquota;

- receio de confisco;

- receio de efeitos controversos, como superdensificação urbana, que é agravado pela experiência traumática da Covid-19;

- desvinculação entre o imposto e a capacidade contributiva;

- não há vantagem substancial em termos cadastrais, uma vez que o desafio de identificar o contribuinte em áreas irregulares e assentamentos permanece inalterado;

- improbabilidade de simplificações nos sistemas de informação sobre preços praticados; e

- probabilidade de arbitrariedades, iniquidades de caráter avaliatório e falta de transparência.

Ao analisar empiricamente o impacto de excluir o valor das construçóes da base de cálculo do IPTU no município de Porto Alegre para os imóveis residenciais, De Cesare et al. (2003) indicam que, em comparação com o sistema vigente, o imposto sobre o valor da terra iria onerar desproporcionalmente as residências unifamiliares e os imóveis de baixo valor em geral, produzindo aumentos exorbitantes em imóveis de baixo padrão construtivo. Em contraste, o imposto sobre o valor da terra beneficiaria os apartamentos, em especial, imóveis grandes, de alto valor e padráo construtivo fino ou luxo. Analogamente, seria esperado 
um aumento significativo na carga tributária de lojas e demais estabelecimentos mercantis horizontais em oposição à redução significativa em unidades comerciais e de serviços nos condomínios verticais.

Como ilustrado por intermédio de exemplos hipotéticos, imóveis antigos sem elevador ou espaço de estacionamento localizados em condomínios verticais pagariam o mesmo imposto que imóveis novos e modernos, visto que a depreciação e a obsolescência seriam ignoradas.

Além disso, avaliar com precisão o valor de terrenos baldios é problemático, devido ao limitado número de transaçôes em cidades consolidadas. Principalmente em áreas centrais, polos comerciais e outras áreas plenamente densificadas, os lotes estáo edificados. De fato, em cidades maiores, os terrenos baldios representam entre 3\% e 12\% dos imóveis cadastrados. Em decorrência, é provável que regras arbitrárias sejam utilizadas nas avaliaçôes, prejudicando inclusive a eficiência econômica do imposto sobre o valor da terra.

No caso de uma cidade com as características de Porto Alegre, claramente, a alteração da base de cálculo para o valor da terra desconsiderando as construçóes tornaria o imposto regressivo para mais de $95 \%$ dos imóveis cadastrados. Além de onerar os imóveis de menor valor, haveria falta de isonomia entre proprietários de bens de valor idêntico. Dificilmente esta seria uma alternativa plausível para municípios altamente urbanizados e verticalizados.

Para comportamentos especulativos localizados, os municípios contam com instrumentos de política urbana, tais como parcelamento, edificação e utilização compulsórias dos imóveis seguidas da aplicação do IPTU progressivo no tempo nos termos do Estatuto das Cidades. Além disso, a legislação atual permite a aplicação de alíquotas mais elevadas para os terrenos baldios. ${ }^{19}$ Cabe a cada município realizar um diagnóstico para entender os seus desafios e implementar estratégias eficazes de política urbana e tributária.

No tocante às alíquotas, a proposta de estabelecer por lei nacional limites mínimos e máximos é, sem dúvida, um retrocesso. Esta alternativa é utilizada em fases iniciais de processos de descentralização. Os municípios brasileiros são entes federativos, cuja autonomia fiscal foi garantida há mais de trinta anos nos termos constitucionais.

Os municípios devem ter plena autonomia para fixar as alíquotas do IPTU devido: i) ao fato de conhecerem as especificidades locais do mercado imobiliário; ii) à relevância das alíquotas para a concretização da política urbana local e da tributação progressiva; iii) à necessidade de equilíbrio entre a magnitude das alíquotas e o nível das avaliaçóes, que varia fortemente entre municípios e é desconhecido pelo parlamento nacional; e iv) à necessidade de dimensionar as alíquotas de acordo com as exigências orçamentárias. Como discutido anteriormente, é preponderante garantir que a magnitude da carga tributária do IPTU seja decorrente da negociação entre os governos municipais e seus munícipes sobre a abrangência e a qualidade dos serviços públicos prestados.

Visando assegurar o interesse local e a justiça social imobiliária, é imperativo que a fixação das alíquotas do IPTU permaneça sob a plena responsabilidade das Câmaras de Vereadores, que são instrumentalizadas por audiências públicas locais. A heterogeneidade dos municípios brasileiros prejudicaria inclusive a fixação de limites para as alíquotas aplicáveis. Cabe ainda salientar que em países onde há grandes interferências em nível nacional ou estadual no imposto imobiliário local, as receitas tendem a ser baixas. É o caso de Áustria,

19. Além de progressivas em razão do valor do imóvel, as alíquotas podem ser diferenciadas por efeito do uso e da localização (art. 156, § 10, inciso II, da CF/1988). 
Alemanha, Noruega, México e Portugal, países que arrecadaram menos que 0,5\% do PIB em 2018, enquanto a arrecadação média dos países da Organização para a Cooperação e Desenvolvimento Econômico (OCDE) foi de 1,1\% do PIB.

$\mathrm{Na}$ realidade, as competências pelo estabelecimento de alíquotas, isençôes tributárias ou incentivos fiscais, inerentes à autonomia municipal, são essenciais para o cumprimento do Pacto Federativo, art. 1º, da CF/1988. Trata-se de uma cláusula pétrea constitucional (art. 60, $\$ 4^{\circ}, \mathrm{CF} / 1988$ ).

Como leciona Kelsen (1998), a democracia se concretiza com a descentralização do poder, portanto, descentralizar é pressuposto constitucional inegociável em um Estado Social Democrático de Direito.

Embora o fortalecimento do IPTU nos últimos dez anos seja indiscutível, é necessário avançar. Com o objetivo de aumentar a equidade e a eficiência deste importante instrumento, é preciso que a reforma tributária absorva apenas dois aspectos:

- estabeleça o intervalo máximo de quatro anos entre as reavaliaçóes realizadas para fins de IPTU; ${ }^{20}$ e

- autorize os municípios a atualizar o valor venal dos imóveis por decreto ou instruçáo normativa para fins de IPTU, como ocorre com os demais tributos.

Além disso, com o objetivo de viabilizar o ordenamento territorial pleno e garantir a racionalidade administrativa, o mesmo nível de governo deveria ser responsável pela tributação da terra urbana e rural, como ocorre na quase totalidade dos países. Seria, portanto, extremamente oportuno que a reforma tributária transferisse na íntegra a competência tributária do ITR aos municípios. A tentativa de superar esse cenário, permitindo a realização de convênios entre o governo federal e o municipal para o repasse da fiscalização do imposto, mostrou-se insuficiente, na medida em que a estrutura legal do ITR permaneceu inalterada.

Cabe ainda lembrar que a base de cálculo do IPTU inclui o valor da terra. Portanto, os benefícios econômicos do imposto sobre o valor da terra estáo presentes nesta forma de tributação, embora sejam distintos dos efeitos da parcela do imposto que incide sobre o valor das construçôes. Assim, a exclusão do valor das construçôes da base de cálculo do IPTU, além de gerar regressividade, seria um equivocado retrocesso.

\section{REFERÊNCIAS}

ANDELSON, R. V. Land-value taxation around the world. 3rd ed. Oxford: Blackwell Publishers, 2000.

ARNOTT, R. Neutral property taxation. [s.l.]: Institute of Business and Economic Research, 2000. (Seminar Paper Series, n. S00-004).

BENTICK, B. L. The impact of taxation and valuation practices on the timing and efficiency of land use. Journal of Political Economy, v. 87, n. 4, p. 859-868, 1979.

BRASIL. Ministério da Fazenda. ITR Convênio. Consulta entes conveniados. Brasília: Receita Federal do Brasil, 2017.

20. 0 PLS no 277/2014 (complementar) alterava 0 art. 11 da Lei de Responsabilidade Fiscal para estabelecer a atualização da Planta Genérica de Valores em periodicidade não superior a quatro anos. No entanto, o PLS foi negado no plenário do Senado Federal em 5 de agosto de 2015 por um voto (quarenta votos favoráveis e dezesseis desfavoráveis do total de 81 senadores), devido à necessidade de quórum especial, aliada à falta de debates sobre o tema. 
BRUECKNER, J. K. A modern analysis of the effects of site value taxation. National Tax Journal, v. 39, n. 1, p. 49-58, 1986.

CARVALHO JUNIOR, P. H. B. Property tax performance and potential in Brazil. 2017. Dissertation (PhD) - University of Pretoria, 2017.

O Imposto sobre Transmissão de Bens Imóveis (ITBI). In: FAGNANI, E. (Org.).

A reforma tributária necessária: diagnóstico e premissas. 1. ed. Brasília: Anfip; Fenafisco; São Paulo: Plataforma de Política Social, 2018. p. 436-456.

DE CESARE, C. M. Condições básicas para garantir a funcionalidade da tributação recorrente ao patrimônio imobiliário urbano e rural. In: FAGNANI, E. (Org.). A reforma tributária necessária: diagnóstico e premissas. 1. ed. Brasília: Anfip; Fenafisco; São Paulo: Plataforma de Política Social, 2018a. p. 369-393.

. Ponderaçóes sobre avanços preponderantes para o fortalecimento da tributação imobiliária no Brasil. In: MARENCO, A.; NOLL, M. I. (Org.). A política, as políticas e os controles: como são governadas as cidades brasileiras. 1. ed. Porto Alegre: Tomo Editorial, 2018b. p. 65-98.

DE CESARE, C. M. et al. Analyzing the feasibility of moving to a land value-based property tax system: a case study from Brazil. Massachusetts: Lincoln Institute of Land Policy, 2003. (Working Paper).

DE CESARE, C. M. et al. La diversidad del reto: factores críticos del desempeño del impuesto a la propiedad inmobiliaria en Brasil. In: BONET, J. A.; MIRANDA, A. M.; MANNHEIM, C. R. P. (Ed.). El potencial oculto: factores determinantes y oportunidades del impuesto a la propiedad inmobiliaria en América Latina. Washington: Banco Interamericano de Desarrollo, 2014. p. 29-54.

EDWARDS, M. E. Site value taxation in Australia. American Journal of Economics and Sociology, v. 43, p. 481-495, 1984.

FARIAS, F. M. G. B.; SILVA, R. P.; LEITE, A. Z. Imposto sobre a Propriedade Territorial Rural. In: FAGNANI, E. (Org.). A reforma tributária necessária: diagnóstico e premissas. 1. ed. Brasília: Anfip; Fenafisco; São Paulo: Plataforma de Política Social, 2018. p. 394-410.

FERNANDES, C. E. IPTU. Texto e contexto. São Paulo: Quartier Latin, 2005.

FLINT, A. Future of density: affordability, equity, and the impacts of an insidious virus. Massachusetts: Lincoln Institute of Land Policy, 2020.

GEORGE, H. Progreso y miseria. New York: Robert Schalkenbach Foundation, 1996.

KELSEN, H. Teoria geral do direito e do Estado. Tradução de Luís Carlos Borges. 3. ed. São Paulo: Martins Fontes, 1998.

LICHFIELD, N.; CONNELLAN, O. Land value taxation in Britain for the benefit of the community: history, achievements and prospects. Massachusetts: Lincoln Institute of Land Policy, 1997.

LUSHT, K. M. The site value tax and residential development. Melbourne, Australia: Smeal College of Business Administration - The Pennsylvania State University, 1992.

MATHIS, E.; ZECH, C. An empirical test: the economic effects on land value taxation. Growth and Change, v. 13, p. 2-5, 1982. 
MCCLUSKEY, W.; FRANZSEN, R. C. D. Land-value taxation in Australia, Jamaica, Kenya, New Zealand and South Africa. In: IRRV INTERNATIONAL CONFERENCE ON LOCAL GOVERnMENT PROPERTYTAXATION, 5., 1999, Cambridge. Proceedings... Cambridge: [s.n.], 1999. Cambridge, USA, 1999.

MCCLUSKEY, W.; WILLIAMS, B. Introduction: a comparative evaluation. In: MCCLUSKEY, W. (Ed.). Property tax: an international comparative review. England: Ashgate Publishing, 1999. p. 1-31.

MILLS, E. S. The economic consequences of a land tax. In: NETZER, D. (Ed.). Land value taxation: can it and will it work today? Massachusetts: Lincoln Institute of Land Policy, 1998. p. 31-48.

NETZER, D. Land value taxation: can it and will it work today? Massachusetts: Lincoln Institute of Land Policy, 1998. 284 p.

NORREGAARD, J. Taxing immovable property: revenue potential and implementation challenges. Washington: IMF, 2013. (Working Paper, n. 13/129).

OATES, W. E.; SCHWAB, R. M. The impact of urban land taxation: the Pittsburgh experience. National Tax Journal, v. 50, n. 1, p. 1-21, 1997.

ORAIR, R. O.; ALBUQUERQUE, P. H. M. Capacidade de arrecadaçáo do IPTU: estimação por fronteira estocástica com dados em painel. Brasília: Ipea, 2017. (Texto para Discussão, n. 2309).

PINTO, V. C. É preciso substituir o IPTU por um imposto sobre o valor da terra. Caos Planejado, 2020.

PLASSMANN, F. The impact of two-rate taxes on construction in Pennsylvania. Dissertation (PhD) - Virginia Polytechnic Institute and State University, 1997. (Unpublished manuscript).

REECE, B. F. State land taxation: a critical review. [s.l.]: Australian Tax Research Foundation, 1992. (Research Study, n. 15).

TIDEMAN, T. N. Taxing land is better than neutral: land taxes, land speculation, and the timing of development. In: WENZER, K. C. (Ed.). Land value taxation: the equitable and efficient source of public finance. London: Shepheard-Walwyn, 1999. p. 109-133.

TIDEMAN, T. N.; JOHNSON, C. A statistical analysis of graded property taxes in Pennsylvania. Massachusetts: Lincoln Institute of Land Policy, 1995. (Working Paper, 95NT2).

UN-HABITAT. Landy and property tax: a policy guide. Nairobi: United Nations Human Settlements Program, 2011.

VICKREY, W. Propositions relating to site-value taxation. In: WENZER, K. C. (Ed.). Land-value taxation: the equitable and efficient source of public finance. London: Shepheard-Walwyn, 1999. p. 37-45.

WEIR, M.; PETERS, L. E. Development, equity, and the graded tax in the city of Pittsburgh. Property Tax Journal, v. 5, p. 71-84, 1986. 


\title{
A DIMENSÃO TRANSFRONTEIRIÇA NAS LIGAÇÕES INTERNACIONAIS ENTRE CIDADES: COMENTÁRIOS SOBRE UMA NOVA INFORMAÇÃO DA REGIC 2018 ${ }^{1,2}$
}

\author{
Rosa Moura ${ }^{3}$ \\ Gustavo Ferreira ${ }^{4}$ \\ Liria Nagamine ${ }^{5}$
}

\section{INTRODUÇÃO}

Com a publicização dos resultados da pesquisa Regióes de Influência das Cidades (Regic) 2018 (IBGE, 2020), que, desde os anos 1960, investiga periodicamente a classificação hierárquica dos centros urbanos e identifica suas respectivas regiôes de influência, as relaçôes internacionais entre municípios brasileiros ganharam maior visibilidade. Trata-se de um levantamento inédito na história da série Regic e seus resultados devem ser considerados um avanço na compreensão das ligaçôes da rede urbana além fronteira. Duas informaçôes foram obtidas nesse levantamento: a atratividade internacional das cidades brasileiras, medida pela capacidade de atração das cidades da faixa de fronteira terrestre - estabelecida pela Lei $\mathrm{n}^{\mathrm{o}}$ 6.634/1979 - a cidades dos países vizinhos; e a conectividade internacional das cidades brasileiras, avaliada pela presença e funcionamento em cidades brasileiras de firmas e serviços vinculados a redes empresariais de companhias com multilocalização em diversos países.

As primeiras são o objeto dos comentários aos quais se volta este texto, dada sua relevante contribuição ao projeto A Política Nacional de Desenvolvimento Regional (PNDR) e a Faixa de Fronteira, em desenvolvimento no Ipea, pois se constata completa aderência de seus resultados a dinâmicas evidenciadas nas unidades identificadas e sugeridas como arranjos transfronteiriços no âmbito desse projeto (Pêgo et al., 2021).

O texto se organiza em três partes, afora esta introdução, que objetivam: i) tecer comentários sobre as motivaçôes que impulsionam a atratividade internacional das cidades da faixa de fronteira, conforme a pesquisa do Instituto Brasileiro de Geografia e Estatística

1. DOl: http://dx.doi.org/10.38116/brua24art8.

2. Os autores agradecem à leitura atenta, aos comentários e às sugestões da parecerista Alessandra Ruffino, que possibilitaram ajustes fundamentais ao texto.

3. Profissional sênior na Diretoria de Estudos e Políticas Regionais, Urbanas e Ambientais (Dirur) do Ipea.

4. Pesquisador do Programa de Pesquisa para o Desenvolvimento Nacional (PNPD) na Dirur//pea.

5. Pesquisadora do PNPD na Dirur/lpea. 
(IBGE); ii) traçar observaçôes sobre a relevância das ligações internacionais na configuração de arranjos transfronteiriços e em sua importância na rede urbana brasileira; e iii) diante dos motivos que estreitam as ligaçôes entre os centros, apontar os elementos mais desafiadores na gestão desses espaços transfronteiriços.

\section{MOTIVAÇÕES À ATRATIVIDADE INTERNACIONAL DAS CIDADES DA FAIXA DE FRONTEIRA}

Na pesquisa Regic 2018 (IBGE, 2020), foi aplicado um questionário específico para identificar as ligaçóes internacionais entre cidades da faixa de fronteira terrestre, com a finalidade de identificar as origens e destinos; os motivos e os graus de atratividade dessas cidades. O questionário foi aplicado a responsáveis pelas agências do IBGE, cujo conhecimento empírico trouxe resposta à indagação: "De quais cidades dos países vizinhos são oriundas as pessoas que vêm adquirir bens e serviços no Brasil?" (IBGE, 2020, p. 147). Movimentos no sentido oposto, do Brasil para cidades dos países vizinhos, também ocorrem, porém não foram contemplados por essa pesquisa.

Os resultados dessa pesquisa permitem observar que a influência de uma cidade, ao fornecer bens e serviços, é proporcional à distância a partir das fronteiras, reduzindo o número de localidades que a ela se relacionam na medida em que se afasta da fronteira. A quantidade dos relacionamentos guarda proporcionalidade à densidade de cada porção fronteiriça, com padrôes mais complexos nas fronteiras do arco Sul que nos arcos Central e Norte.

Paraguai e Argentina são os países com os maiores números de cidades (68 e 57, respectivamente) que realizam ligaçóes com cidades brasileiras, conforme mostra a tabela 1. Vêm seguidos por Uruguai e Bolívia. Rio Grande do Sul é o estado com o número mais elevado de cidades com atratividade internacional na faixa de fronteira (89 cidades). Paraná e Mato Grosso do Sul vêm na sequência, com respectivamente 50 e 35 cidades.

TABELA 1

Países e número de cidades de origem e Unidades da Federação (UFs) e número de cidades de destino das ligações internacionais

\begin{tabular}{lclc}
\hline País de origem & Número de cidades & UF de destino no Brasil & Número de cidades \\
\hline Paraguai & 68 & Rio Grande do Sul & 89 \\
Argentina & 57 & Paraná & 50 \\
Uruguai & 38 & Mato Grosso do Sul & 35 \\
Bolívia & 26 & Amazonas & 10 \\
Peru & 12 & Rondônia & 10 \\
Venezuela & 9 & Acre & 9 \\
Colômbia & 8 & Roraima & 9 \\
Equador & 3 & Santa Catarina & 8 \\
Guiana & 3 & Mato Grosso & 4 \\
Guiana Francesa & 1 & Amapá & 1 \\
Suriname & 1 & Pará & 1 \\
Total & $\mathbf{2 2 6}$ & Total & $\mathbf{2 2 6}$ \\
\hline \multicolumn{1}{c}{ Fonte: IBGE (2020). } & & &
\end{tabular}

Das ligaçóes internacionais computadas, 15 podem ser consideradas de longa distância e 211 descrevem fluxos de curta distância. Somadas, apontam para 226 ligaçóes internacionais. Os fluxos direcionados a cidades da faixa de fronteira representam majoritariamente 
contatos de curta distância, como mostra o mapa 1. Os fluxos de longa distância, nem sempre destinados a cidades da linha de fronteira, registram uma única finalidade no destino, constatadas em três motivaçóes: i) busca por ensino superior, nas ligaçóes entre Bogotá, Caracas, Lima e Quito com os municípios Capão do Leão e Pelotas (Rio Grande do Sul), entre Lima e Rio Grande (Rio Grande do Sul) e entre Tacna (Peru) e Sant'Ana do Livramento (Rio Grande do Sul); ii) atividades esportivas, nos fluxos entre Lima, Quito e Santa Cruz de la Sierra, com Alegrete (Rio Grande do Sul) e entre Medellín (Colômbia) e Chapecó (Santa Catarina); e iii) atividades culturais, unicamente na ligação entre Buenos Aires e Corumbá (Mato Grosso do Sul).

\section{MAPA 1}

América do Sul: ligações internacionais com destino a municípios da faixa de fronteira terrestre (2018)

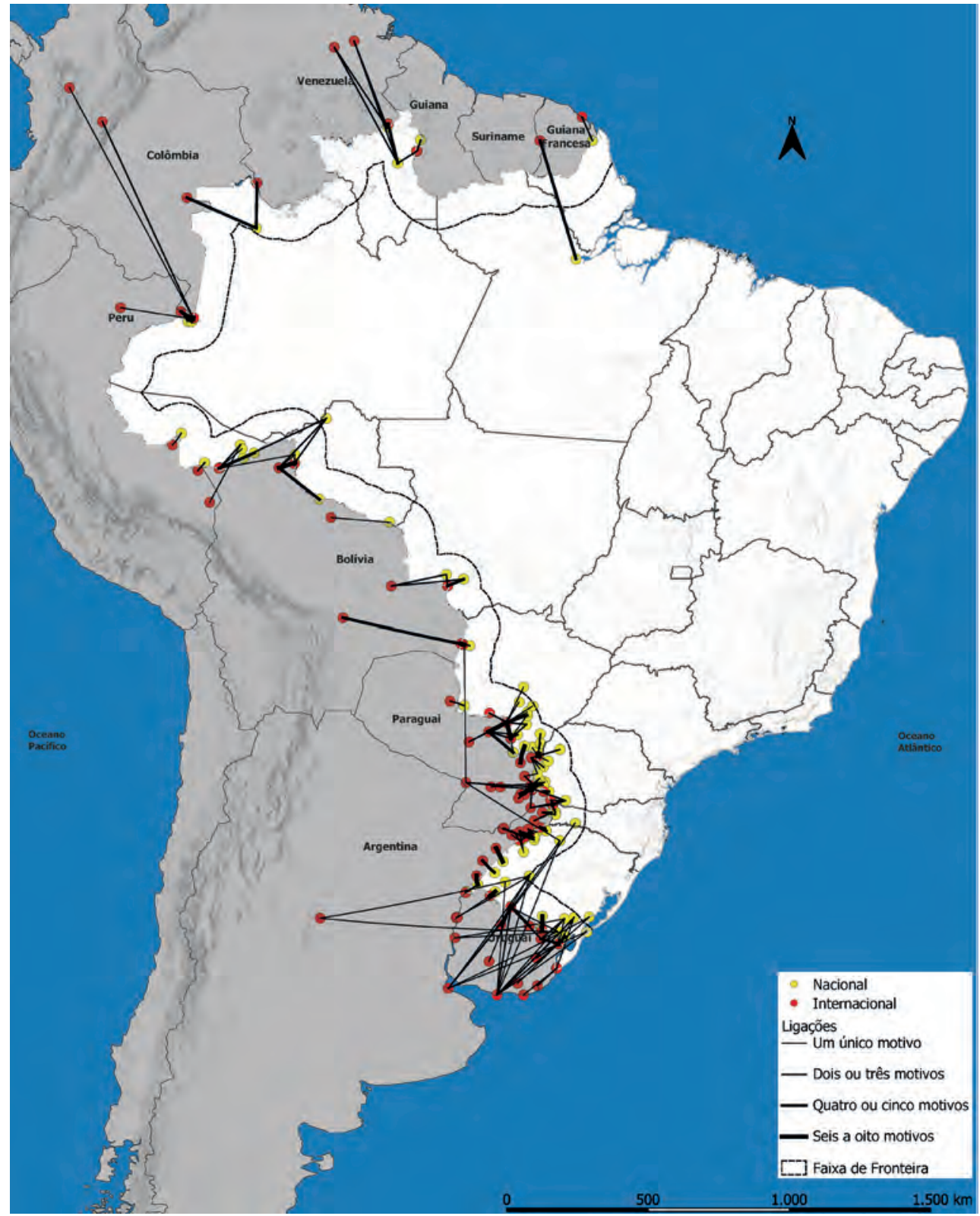

Fonte: IBGE (2020)

Elaboração da Equipe Fronteiras//pea.

Obs.: 1. Não foram mapeadas as ligações de longa distância entre: Bogotá-Capão do Leão, Pelotas; Buenos Aires-Corumbá; Caracas-Capão do Leão, Pelotas; Lima-Alegrete, Capão do Leão, Pelotas, Rio Grande; Medellín-Chapecó; Quito-Alegrete, Capão do Leão, Pelotas; Santa Cruz de la Sierra-Alegrete; Tacna-Santana do Livramento.

2. Figura cujos leiaute e textos não puderam ser padronizados e revisados em virtude das condições técnicas dos originais (nota do Editorial). 
Segundo o IBGE (2020, p. 148), no caso da primeira motivação, os deslocamentos para Capão do Leão e Pelotas, ambas no Rio Grande do Sul, ocorrem em virtude "dos campi da Universidade Federal de Pelotas (Ufpel) realizarem convênios com bolsas de graduação e pós-graduação destinados a alunos de países sul-americanos. No caso específico da Venezuela, há bolsas voltadas para refugiados". A atratividade de Alegrete para esportes se deve a um torneio internacional anual infantil de futebol, considerado um dos maiores eventos do tipo na América Latina, e que é realizado há mais de trinta anos. No caso de Chapecó, existem as partidas internacionais.

Das 226 ligaçóes internacionais, 75 ocorreram por uma única motivação, 83 por dois ou três motivos, 30 por quatro a cinco motivos e 23 por seis a oito motivos. Este último conjunto expressa uma forte inteiração transfronteiriça entre cidades localizadas na linha de fronteira ou, quando não, por estarem integradas a algum arranjo transfronteiriço, como Bagé e o arranjo transfronteiriço de Aceguá (Rio Grande do Sul)-Acegua (Uruguai); e Mundo Novo (Mato Grosso), ao de Guaíra (Paraná)-Salto del Guairá (Paraguai).

Tendo em consideração os 563 fluxos detectados nas 226 ligaçóes entre cidades brasileiras e cidades dos países vizinhos, sejam de curta ou longa distância, constata-se que as atividades culturais são as principais motivaçóes, estando presente em 125 fluxos, ou $22,2 \%$ do total dos fluxos. Além de atividades rotineiras de proximidade, comuns nos arranjos transfronteiriços, em cidades mais distantes da linha de fronteira a atratividade se dá pela realização de festivais e eventos.

O segundo motivo mais referenciado é compra de vestuário ou calçados, motivo de 115 fluxos (20,4\%), e o terceiro, a busca por serviços de saúde de baixa e média complexidade, em 86 fluxos (15,3\%). Neste caso, a assimetria entre as cidades dos dois lados da fronteira na oferta desse serviço torna algumas cidades brasileiras atrativas, mas há casos em que são brasileiros que recorrem a esse tipo de serviço no país vizinho, particularmente na fronteira com o Uruguai. Outra motivação é a oferta pública universalizada no Brasil, enquanto nos países vizinhos a atenção primária se encontra privatizada.

Analisando a origem, Paraguai e Argentina registram o maior número de fluxos de ligação entre as cidades, respectivamente 177 e 143, e ambos são movidos pelas principais motivaçóes consideradas na pesquisa. No caso do Paraguai, com maior peso em relação às atividades culturais ( 45 registros) e serviços de saúde de baixa e média complexidade (31); no da Argentina, em compra de vestuário e calçados (41), compra de móveis e eletroeletrônicos (28) e atividades culturais (27). Uruguai, Bolívia e Colômbia também atendem às oito motivaçôes de buscas: no Uruguai, predominam atividades culturais e compras tanto de vestuário e calçados quanto de móveis e eletrodomésticos; na Bolívia, repetem-se nessas compras e acrescentam-se os serviços de saúde de baixa e média complexidade; e na Colômbia, com menor número total de fluxos (20), recaem sobre compras de vestuário e calçados e busca de ensino superior. Os demais países possuem números menores de fluxos e motivaçóes específicas, mas mesmo assim, os limítrofes apresentam um leque maior de motivaçóes.

Em se tratando das UFs, Rio Grande do Sul, Paraná, Mato Grosso do Sul, com mais de 100 registros de fluxos, e Amazonas, com apenas 32, exercem atratividade pelas oito motivaçôes para as ligaçóes internacionais entre cidades. As três primeiras UFs têm nas atividades culturais a principal motivação; a segunda motivação no Rio Grande do Sul e do Mato Grosso do Sul são as compras de vestuário e calçados; no Paraná e também no Mato Grosso do Sul, a busca por serviços de saúde de baixa e média complexidade. No Amazonas, 
a principal motivação são as compras de vestuário e calçados, seguida por serviços de saúde de baixa e média complexidade. Observa-se que essas três motivaçôes estão presentes na atratividade das cidades em todas as UFs da faixa de fronteira.

Os destinos com o maior número de cidades de origem das ligaçóes internacionais e o maior elenco de motivos para deslocamentos vindos do estrangeiro correspondem a arranjos populacionais (APs) internacionais e respeitam a seguinte ordem de grandeza: i) maior número de municípios de origem e de motivos: Foz do Iguaçu (Paraná) e Ponta Porã (Mato Grosso do Sul); ii) elevado número de motivaçóes e procura por mais de uma cidade: Corumbá (Mato Grosso do Sul) e Guajará-Mirim (Roraima); e iii) elevado número de motivaçôes, porém procurada por uma única cidade: Tabatinga (Amazonas), Mundo Novo e Sete Quedas (Mato Grosso do Sul), Bagé, Jaguarão, Quaraí, Santana do Livramento, São Borja e Uruguaiana (Rio Grande do Sul), Guaíra e Barracão (Paraná) e Dionísio Cerqueira (Santa Catarina) - estes últimos, integrantes do mesmo AP internacional.

Em termos de padrão, observa-se uma complexidade decorrente de múltiplas ligaçôes entre cidades na porção fronteiriça do Paraná com Paraguai e Argentina, o que sugere, conforme IBGE (2020, p. 147) "uma interpenetração econômica da área para além do conhecido polo comercial Foz do Iguaçu (PR)-Ciudad del Este (Paraguai)". Também há maior penetração no território de ambos os países nas ligaçôes de cidades do Rio Grande do Sul com cidades da Argentina e Uruguai.

Em termos de dificuldade de acesso, a ligação entre a localidade de Cottica (Suriname) e o AP Laranjal do Jari (Amapá)-Almeirim (Pará) é explicada pelo IBGE (2020, p. 147) como devida a que os deslocamentos "não se dão entre sedes urbanas, mas entre aldeias indígenas situadas nos dois países. Trata-se de um movimento esporádico realizado, exclusivamente, por via aérea e, eventualmente, preenchendo diversos temas, como compras de vestuário e calçados, saúde, lazer, entre outros." Também São Gabriel da Cachoeira (Amazonas) se vale da dificuldade de acesso de cidades fronteiriças da Colômbia e Venezuela com as centralidades dos respectivos países. "A cidade brasileira passa a funcionar como a única referência de centralidade de fato dada a convergência da rede fluvial, que é usada como meio de transporte por aquelas populaçóes" (IBGE, 2020, p. 148).

Cabe salientar, para além das motivaçóes avaliadas pela pesquisa Regic de 2018 (IBGE, 2020), que outras, sintetizadas na sequência, foram relatadas por participantes fronteiriços nas atividades desenvolvidas nos arcos Norte, Central e Sul, no projeto em curso e nas visitas aos arranjos transfronteiriços realizadas pela equipe Ipea (Pêgo et al., 2021). A essas se somam outras que resultaram da pesquisa de campo realizada no âmbito do projeto do Ministério da Justiça e Cidadania: Municípios de Fronteira: mobilidade transfronteiriça, migração, vulnerabilidades e inserção laboral (Brasil, 2016b). Em ambos os casos referem-se a ligaçóes nos dois sentidos entre os países.

Duas motivaçôes urbanas e rurais fazem o amálgama da interação nas áreas transfronteiriças. Uma dessas, generalizada aos três arcos, são os fluxos que se ativam nas relaçôes familiares, em laços de parentesco, compadrios e amizades que desconhecem fronteiras - elas induzem trocas culturais e a manifestação de uma interculturalidade que enriquece as relaçóes sociais e motivam deslocamentos internos aos arranjos para a vivência do cotidiano. Outra motivação se expressa na mobilidade intensa de povos indígenas, particularmente nos arcos Norte e Central, e sua busca, nas áreas urbanas, por serviços de saúde e assistência social, mas também para atividades informais e mendicância. Entretanto, um ir e vir cotidiano 
ou esporádico adquire especificidades em cada arco fronteiriço, e no próprio interior deles, pois têm relaçóes diretas com a natureza das interaçóes que se dão com cada país vizinho.

No arco Norte, de modo geral, se trata de um movimento informal que alimenta o mercado de trabalho em atividades extrativas ou tipicamente urbanas; são peculiares ao arco os deslocamentos para atividades no garimpo, particularmente entre municípios brasileiros e Guiana Francesa, Suriname e Venezuela. Com este país, a compra de combustível já foi uma das principais motivaçóes de busca por brasileiros.

No arco Central também se destacam os fluxos de pessoas para trabalho em atividades urbanas e rurais, a maioria por trabalhadores informais, pouco especializados, que cruzam a fronteira do Brasil em direção à Bolívia ou ao Paraguai e vice-versa, assim como os fluxos para estudo, nos ensinos fundamental e médio, nas escolas urbanas e rurais, localizadas próximas à fronteira, e educação superior, fundamentalmente cursos de medicina, em cidades da Bolívia e do Paraguai. Também são comuns fluxos para a busca de serviços públicos no Brasil, particularmente saúde, dada a não universalização da saúde pública nos países vizinhos e, no sentido inverso, a procura por brasileiros pelo comércio de importados nos países vizinhos. Uma peculiaridade na movimentação transfronteiriça na fronteira com Bolívia é a predominância de bolivianos na produção para comercialização de hortigranjeiros nas cidades fronteiriças brasileiras.

Além das motivações para trabalho, consumo e uso de serviços públicos, que se repetem nos três arcos, no arco Sul, há um movimento muito intenso gerado pela atividade turística, particularmente no caso do Parque Nacional do Iguaçu, visitado dos lados brasileiro e argentino, que se associa ao turismo de compras de produtos importados nos grandes centros comerciais e comércio de rua, majoritariamente em Ciudad del Este. O turismo de compras também é um forte atrativo em Pedro Juan Caballero e outras cidades do Paraguai, assim como em lojas francas do Uruguai. A indústria do turismo emprega, nas atividades do secundário e terciário, formal e informalmente, moradores dos dois ou três lados da fronteira, que circulam cotidianamente no interior dos arranjos, e trabalham como lojistas, atendentes, ambulantes, trabalhadores da construção civil, serviços domésticos, entre outros. No caso da fronteira com o Uruguai, a busca por serviços públicos de saúde e educação também ocorre na direção inversa, muitas vezes justificada pela menor distância ou maior facilidade de acesso a cidades do país vizinho. Há que salientar que a maioria dos arranjos transfronteiriços na fronteira com a Argentina sofre com as dificuldades da travessia por balsas.

Outra motivação de deslocamentos de brasileiros registrada nos três arcos da fronteira é a frequência a bares, casas noturnas, restaurantes, casas de jogos, entre outras diversóes nas cidades "do lado de lä" das fronteiras. Associa-se a ela o movimento de ilícitos, como tráfico de drogas e de pessoas, particularmente mulheres, crianças e outros segmentos vulneráveis, como indígenas, para a prostituição ou para servirem de "mulas" no tráfico de drogas.

Por fim, cabe destaque aos movimentos pendulares para trabalho e/ou estudo em países estrangeiros, cujas informaçōes, disponibilizadas pelo IBGE no censo demográfico de 2010, oferecem importantes subsídios para análises de fluxos de municípios brasileiros com destino a outros países (nesse caso não foram pesquisados os que ocorrem na direção inversa, de estrangeiros com destino aos municípios brasileiros). ${ }^{6}$

6. Análises específicas sobre o tema constam em estudos que integram o projeto em desenvolvimento no Ipea (Cardoso e Moura, 2017; Deschamps, Delgado e Moura, 2018). 
O resultado dessas pesquisas confirma que há uma dimensão transfronteiriça que perpassa a linha de fronteira terrestre, assumindo maior relevância nos arranjos espaciais bi ou trinacionais. Uma dimensão que assimila a diversidade de seus povos e impulsiona uma intensa e contínua mobilidade transfronteiriça, pendular, de passagem ou migratória, que amplia a multidimensionalidade cultural, econômica e social, a maioria estabelecida na esfera do informal, e impóe açóes que garantam preservar identidades e fortalecer a interculturalidade. Tal diversidade por vezes acelera processos que exigem reflexão apurada e açóes emergenciais.

\section{A ATRATIVIDADE INTERNACIONAL DOS ARRANJOS TRANSFRONTEIRIÇOS}

As informaçôes sobre a atratividade internacional das cidades brasileiras, disponibilizadas pela Regic 2018, encontraram completa consonância às configuraçôes espaciais que no projeto citado são consideradas arranjos transfronteiriços. Tratam-se de espaços de ocupação contínua ou de forte conexão entre cidades de países vizinhos em uma zona onde convivem diferentes povos e culturas, por onde perpassam fluxos de interaçáo cotidianos e se realizam atividades comuns aos países fronteiriços; uma zona híbrida, na qual se mesclam identidades originais e se constrói uma nova identidade (Moura e Oliveira, 2018). ${ }^{7}$ São arranjos resultantes de uma configuração polidimensional, ou seja, tanto referente à dimensão gerada pela aglomeração, cidade ou povoado de cada lado da fronteira, quanto à dimensão que se constitui a partir de uma simbiose nas interaçóes cotidianas entre essas, prescindindo a linha de fronteira. E se confirmam na compreensão do IBGE (2020, p. 147) de que a "hinterlândia das Cidades brasileiras avança sobre o território dos demais países, sendo referência tanto de cidadáos estrangeiros quanto de brasileiros residentes no exterior para a aquisiçáo de produtos e o usufruto de serviços".

No âmbito do projeto em desenvolvimento pelo Ipea, foram identificados 32 arranjos transfronteiriços, integrados por 39 municípios brasileiros e 41 dos países vizinhos, somando 80 unidades político-administrativas locais (Pêgo et al., 2021). Alguns desses arranjos integram o elenco das cidades gêmeas, dispostas pelo Ministério do Desenvolvimento Regional (MDR) (Brasil, 2016a; 2019); outros, os arranjos populacionais internacionais, conforme IBGE (2020).

Distribuem-se entre os três arcos da fronteira terrestre: sete arranjos no arco Norte, sendo dois trifronteiriços (Brasil, Colômbia e Peru; e Brasil, Peru e Bolívia); oito arranjos no arco Central, um deles compartilhado com o arco Sul (Mato Grosso do Sul, Paraná e Paraguai); e 17 arranjos no arco Sul, sendo dois compartilhados entre estados (o já citado e outro entre Paraná, Santa Catarina e Argentina) e dois arranjos em fronteira tríplice (Brasil, Paraguai e Argentina; e Brasil, Argentina e Uruguai), conforme mostra o mapa 2. Outros arranjos se conformam na linha de fronteira terrestre, demandantes de estudos específicos e mais detalhados para sua delimitação, mas já detectadas as ligações internacionais com municípios dos países vizinhos na Regic 2018. Outros municípios da linha de fronteira, sem continuidade/contiguidade de ocupação observadas, também se confirmam ligaçôes com municípios e povoados de países vizinhos.

7. As publicações resultantes do projeto em desenvolvimento pelo Ipea (Pêgo e Moura, 2018; Pêgo et al., no prelo), tomado como base para se tecer os comentários propostos neste texto, trazem discussões teórico-conceituais sobre relações interfronteiriças e transfronteiriças, conceitos sobre várias dimensões sociais e geográficas das fronteiras, entre outros temas. 
MAPA 2

Brasil: arranjos transfronteiriços (2019)

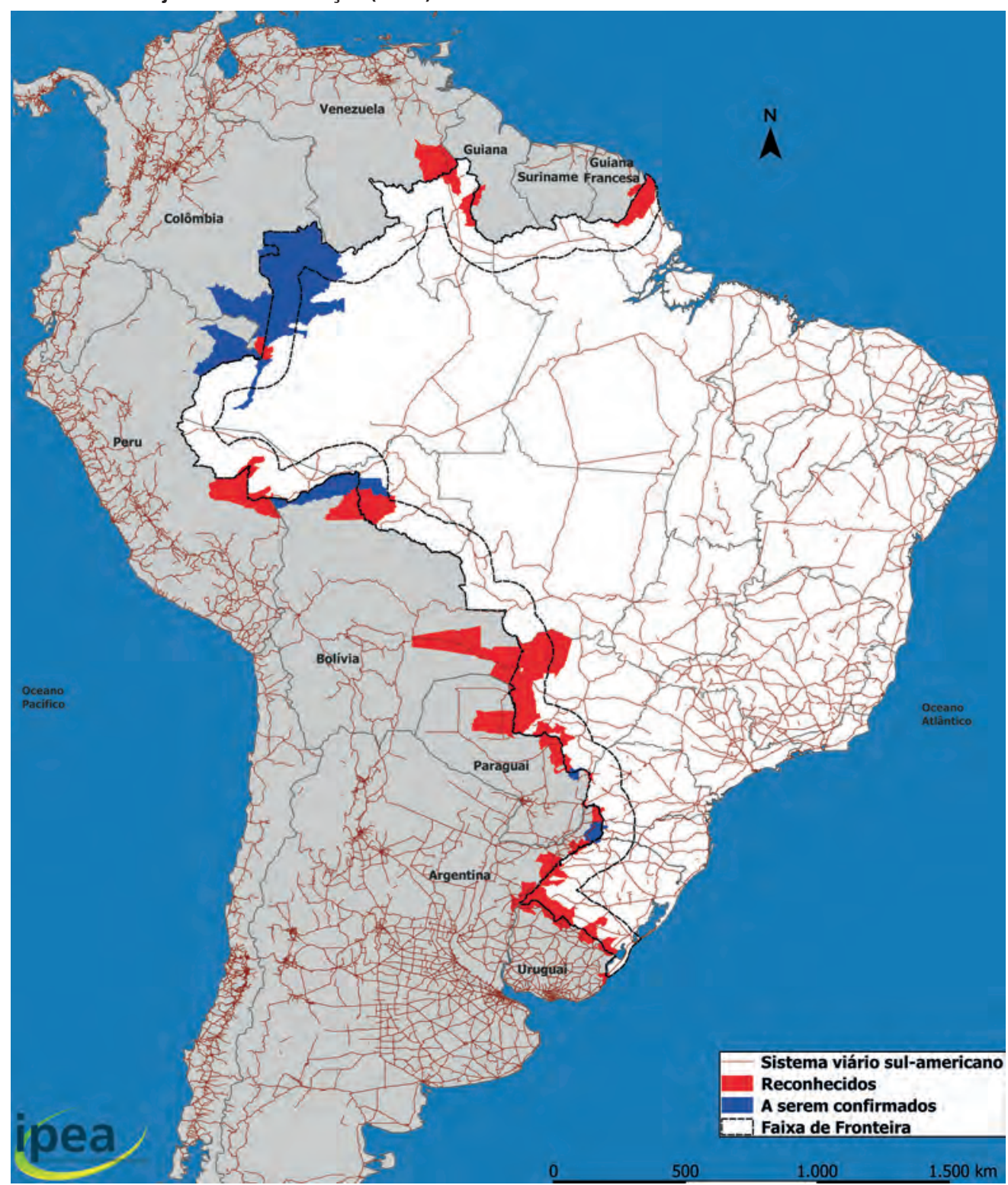

Fonte: Pêgo et al. (2021); DNIT, 2018

Elaboração da Equipe Fronteiras/lpea.

Obs.: Figura cujos leiaute e textos não puderam ser padronizados e revisados em virtude das condições técnicas dos originais (nota do Editorial).

Chama-se a atenção para o fato de que muitos desses possíveis arranjos ou cidades com ligaçôes internacionais confirmadas, nos arcos Norte e Central, têm na dimensão transfronteiriça relações entre indígenas dos distintos países, não se configurando como unidades derivadas da ocupação urbana. Da mesma forma, as relaçôes de trabalho em atividades do setor primário, que consolidam relações transfronteiriças nesses mesmos arcos, provocam similar simbiose em toda a unidade municipal.

A configuração de arranjos espaciais é uma tendência da urbanização nas regiốes de fronteiras, pela intensa comutação e interação entre os povos e pela sinergia impulsionada na oscilaçáo de oportunidades econômicas e cambiais entre os países, que gera a dimensão transfronteiriça, indo além da escala local de cada cidade. Eles sintetizam os mais elevados graus de urbanização; predominância de ocupação em atividades não agrícolas; desenvolvimento de 
fluxos pendulares - nesse caso entre municípios de diferentes países, para trabalho, estudo, consumo de bens e acesso a serviços -; e manchas contínuas de ocupação, sobre as quais a linha de fronteira tem completa porosidade, viabilizando as interaçóes e a mobilidade transfronteiriça, desempenhando importante papel de intermediação nas redes urbanas dos distintos países. Constituem mosaicos urbanos complexos, que devem ser compreendidos em sua totalidade, mas ainda pouco reconhecidos e priorizados na agenda governamental, portanto carentes de políticas públicas adequadas às suas demandas e ao seu papel na rede de cidades.

Os resultados da pesquisa Regic 2018 tornam evidente a qualificação das cidades que integram arranjos transfronteiriços, dada a elevação do nível de seu posicionamento na hierarquia urbana brasileira. A principal elevação de nível foi constatada em relação ao arranjo populacional internacional (AP) ${ }^{8}$ de Foz do Iguaçu (Paraná)-Ciudad del Este (Paraguai), que agrega um número maior de municípios que os considerados pelo IBGE, tanto do Brasil, quanto do Paraguai, além de Puerto Iguazú (Argentina). Esse AP internacional teve sua classificação elevada de centro sub-regional para capital regional. Outros APs internacionais elevaram a classificação de centros de zona para centros sub-regionais, casos de Brasileia/Epitaciolândia (Acre)-Cobija (Bolívia); Guajará-Mirim (Roraima)-Guayaramerín (Bolívia); Corumbá/Ladário (Mato Grosso do Sul)-Puerto Quijarro/Puerto Suárez (Bolívia); Ponta Porã (Mato Grosso do Sul)-Pedro Juan Caballero/Zanja Pytá (Paraguai); Guaíra (Paraná)-Mundo Novo (Mato Grosso do Sul)-Salto del Guairá (Paraguai); Sant'Ana do Livramento (Rio Grande do Sul)-Rivera (Uruguai); e São Borja (Rio Grande do Sul)-Santo Tomé (Argentina), além de Tabatinga (Amazonas)-Leticia (Colômbia)-Santa Rosa (Peru). Entre os arranjos transfronteiriços, apenas Cáceres (Mato Grosso)-San Matías (Bolívia) teve queda dentro do próprio nível de classificação, passando de centro sub-regional A para B.

De modo geral, os municípios da faixa de fronteira e suas centralidades mais expressivas demonstram pequena articulação à rede urbana brasileira, sendo que o mesmo ocorre em relação aos municípios fronteiriços e às redes de cidades dos respectivos países. Distância das centralidades principais e meios de comunicação e acessibilidade precários são os principais limitantes das conexôes entre os centros, particularmente nos arcos Norte e Central (Pêgo et al., 2021). Essas condiçôes de precariedade atribuem um papel de redobrada importância aos arranjos transfronteiriços, como centralidades com influência regional sobre municípios dos países vizinhos, pois muitas vezes as dificuldades de conexão e as distâncias são maiores em relação aos centros principais dos respectivos países.

No arco Sul, as cidades da faixa de fronteira guardam maior proximidade às principais centralidades da rede urbana brasileira e possuem vias de ligação com centralidades dos países vizinhos em melhores condiçôes que nos demais arcos (mapa 3). Mesmo assim, há cidades na fronteira do Rio Grande do Sul com mais facilidade de acesso a centralidades dos países vizinhos que às brasileiras (Pêgo et al., 2021). Particularmente no arco Norte, há localidades sem acesso pelo sistema rodoviário, a exemplo do arranjo transfronteiriço Tabatinga (Amazonas)-Letícia (Colômbia)-Santa Rosa (Peru), no qual o acesso é por via aérea ou fluvial. Ainda assim, vale apontar que o aeroporto na regiáo não opera voos internacionais.

8. Para o IBGE (2020, p. 11), a unidade urbana de análise e exposição dos resultados dessa pesquisa trata-se de município e AP - este considerando o "fato de que a unidade funcional Cidade, objeto do atual estudo, pode vir a ser composta não apenas por um, mas por vários Municípios que são indissociáveis como unidade urbana. Trata-se de Municípios conurbados ou que possuem forte movimento pendular para estudo e trabalho, com tamanha integração que justifica considerá-los como um único nó da rede urbana". 
MAPA 3

Brasil: hierarquia e rede de relações dos centros urbanos da faixa de fronteira (2018)

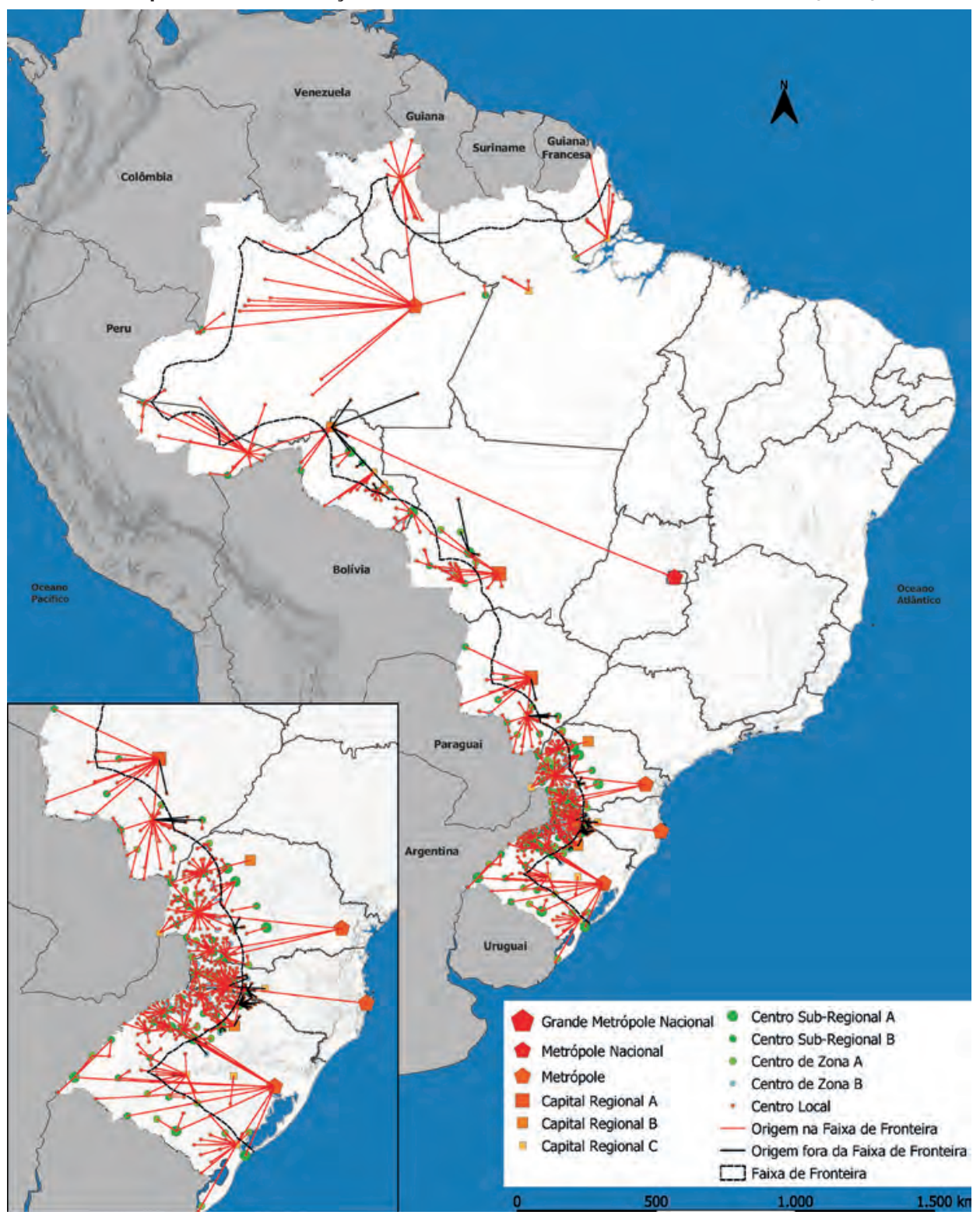

Fonte: IBGE (2020)

Elaboração da Equipe Fronteiras/lpea.

Obs.: 1. Foram mapeadas as cidades de origem que integram a faixa de fronteira, e separadas apenas as ligações com vínculos à rede urbana (resposta "sim"); das que não integram a faixa de fronteira, foram identificados os destinos dentro da faixa e mapeados os vínculos (resposta "sim"). Ou seja, examinou-se a faixa de fronteira sob a perspectiva de quem procura e de quem é procurado, mesmo que por cidades de fora dela. 2. Figura cujos leiaute e textos não puderam ser padronizados e revisados em virtude das condições técnicas dos originais (nota do Editorial).

Segundo a Regic 2018, são poucos os municípios da faixa de fronteira classificados nos patamares superiores da hierarquia de centros, não ocorrendo classificação na condição de metrópole ou capital regional A. Classificados como capitais regionais $\mathrm{B}$, encontram-se os APs de Porto Velho (capital de Rondônia), no arco Central; e Cascavel (Paraná) e Chapecó (Santa Catarina), no arco Sul. Como capitais regionais C, as capitais estaduais Rio Branco (Acre) e Boa Vista (Roraima), no arco Norte, assim como Dourados (Mato Grosso do Sul), no arco Central, e os APs de Pelotas (Rio Grande do Sul) e Foz do Iguaçu (Paraná) no arco Sul. Dois destaques são necessários: i) todos os centros classificados como capitais regionais no arco Norte são capitais de Unidades da Federação (UFs), cuja posição reforça a faixa de fronteira nesse arco, como também de Porto Velho, no arco Central; e ii) a configuraçáo 
espacial de arranjos populacionais, comum em regiôes adensadas, passa a pontuar também os municípios mais urbanizados dos arcos Norte e Central.

Há uma categoria que participa do exercício das relaçóes transfronteiriças que merece futura reflexão: a de cidade "conectora" (Egler, 2015). Ela se refere a centralidades da faixa de fronteira, como algumas capitais regionais, e também outras, situadas fora da faixa de fronteira, casos de Manaus e Cuiabá, que funcionam como conectoras na integração e na interaçáo transfronteiriça, articulando atividades econômicas e socioculturais, tornando-se destinos iniciais de trajetórias longas de migraçóes internacionais, entre outras.

\section{ALGUNS DESAFIOS PARA A GESTÃO}

Pela unidade espacial configurada, os arranjos transfronteiriços exigem políticas públicas adequadas às suas especificidades e que contemplem o grande número de funçóes públicas de interesse comum entre municípios de diferentes naçôes. O mesmo exigem as pequenas cidades ou povoados da linha de fronteira, que igualmente funcionam como portais para essa mobilidade. Ambos padecem de muitos males em comum à espera de políticas públicas mais efetivas.

Entre destaques dos participantes das atividades e estudos considerados no projeto que serve de parâmetro a esta análise constam: i) a urgência de medidas que assegurem o livre trânsito das pessoas residentes, com transporte urbano de passageiros que garanta a conectividade cotidiana; ii) a gestáo oficialmente compartilhada da prestação dos serviços de saúde, educação e assistência social, particularmente aos segmentos mais vulneráveis da população; iii) a oferta de moradia; iv) o acesso e a participaçáo em atividades culturais e esportivas; v) a garantia da documentação para o trabalho e usufruto dos direitos sociais; vi) o saneamento básico e a gestão ambiental, posto que a demarcação de fronteira não tem poder de influir em processos naturais; vii) a compatibilização das legislaçôes municipais e a convergência entre planos diretores urbanos e regulação urbanística; viii) a implementaçáo da governança compartida com a adequação da legislação de cooperação transfronteiriça; entre outros.

Além desses, o grande desafio no interior dos espaços transfronteiriços é a gestão do controle da fronteira, a partir de uma nova compreensão de seu significado, não mais como um elemento que separa, mas que une. A pandemia do novo coronavírus deixou evidente que o súbito fechamento das fronteiras terrestres, por meses, separou famílias e bloqueou relações cotidianas vitais, como acesso à saúde e ao trabalho. Para evitar tais situaçôes, qualquer controle fronteiriço deveria se dar no exterior da unidade urbana constituída, em um raio a ser definido a partir de sua centralidade. Arranjos transfronteiriços requerem ser compreendidos como uma unidade, e seus moradores, como cidadáos de um mesmo espaço, cuja gestão deve resultar de acordos e práticas bi ou trinacionais. Faz-se urgente, portanto, que a natureza das relaçóes transfronteiriças seja assimilada e difundida, e que as políticas para fronteira incorporem a dinâmica real desses espaços, em sua diversidade e distintos graus de complexidade morfológica e social, respeitando a especificidade de seus moradores e assumindo a existência de uma nova cidadania: a dos povos transfronteiriços.

\section{CONSIDERAÇÕES FINAIS}

Mais uma vez o IBGE disponibiliza uma importante contribuição à pesquisa sobre as relações entre as cidades brasileiras, inovando, desta feita, com a abordagem também sobre as ligaçôes internacionais entre centros. A leitura dos resultados dessa nova fonte de dados, à luz dos estudos do projeto A Política Nacional de Desenvolvimento Regional (PNDR) e a Faixa de Fronteira, em desenvolvimento no Ipea, demonstrou completa aderência à realidade fronteiriça. 
Aderência que se expressa: i) na ampliação da hinterlândia de cidades brasileiras sobre espaços dos países vizinhos; ii) na especificação dos motivos que impulsionam a atratividade dessas cidades; iii) na confirmação daqueles que promovem a interação cotidiana e instauram uma dimensão transfronteiriça nesses espaços; e iv) no reforço que essa atratividade desencadeia no leque funcional de arranjos transfronteiriços, posto que muitos obtiveram reposicionamento ascendente na escala da hierarquia urbana brasileira na pesquisa Regic de 2018.

Para o projeto do Ipea, as informaçóes contribuíram, de imediato, para salientar a importância em se aprofundar o estudo, voltando-se a configuraçôes transfronteiriças ainda não elencadas entre as cidades-gêmeas, do MDR, ou os arranjos populacionais internacionais, do IBGE. Esse aprofundamento já faz parte das propostas da etapa que se inicia no projeto e que, certamente, vai se valer muito dos dados disponibilizados. Apenas se ressente que o levantamento da atratividade internacional ainda não contemple a direção oposta, no sentido das cidades brasileiras para cidades dos países vizinhos, dada a impossibilidade de formas diretas de captá-los, como justifica o IBGE.

Quanto aos arranjos populacionais internacionais, a base de dados que agrega os produtos integrantes da Regic 2018 ofereceu uma atualização dos municípios componentes nesses arranjos. Confirmou-se também que todos já estavam considerados no projeto do Ipea como arranjos transfronteiriços. Porém, nessa relação sente-se falta de alguns importantes, já relacionados entre as cidades-gêmeas, que, embora não configurem manchas de ocupação urbana em contiguidade ou continuidade, realizam uma forte interação pela conectividade motivada pelos mesmos serviços e atividades medidos no levantamento de atratividades. Casos, por exemplo, de Pacaraima (Roraima)-Santa Elena de Uairén (Venezuela)-Cáceres (Mato Grosso)-San Matías (Bolívia), entre outros.

Essas duas breves lacunas absolutamente não comprometem a importância das informaçôes analisadas nesses comentários. Outra vez, parabeniza-se o IBGE pela longevidade, sistematicidade e aprimoramentos contínuos à pesquisa Regic, e se agradece pela publicização do acesso a informaçóes que contam a história da rede urbana brasileira e permitem que se ensaie tendências sobre seus rumos futuros.

\section{REFERÊNCIAS}

BRASIL. Ministério da Integração Nacional. Portaria no 213 de 19 de julho de 2016. Estabelece o conceito de "cidades-gêmeas" nacionais, os critérios adotados para essa definição e lista todas as cidades brasileiras por estado que se enquadram nesta condição. Diário Oficial da Uniáo, Brasília, 20 jul. 2016a. Disponível em: <http://www.in.gov.br/materia/-/asset_publisher/Kujrw0TZC2Mb/ content/id/21772550/do1-2016-07-20portaria-n-213-de-19-de-julho-de-2016-21772471>. Acesso em: 20 jan. 2020.

. Ministério da Justiça e Cidadania. Municípios de fronteira: mobilidade transfronteiriça, migração, vulnerabilidades e inserção laboral. Brasília: MJ, 2016b. (Relatório de Pesquisa).

. Ministério da Integração Nacional. Portaria no 1.080 de 24 de abril de 2019. Inclui o Município no Anexo da Portaria n. 213, de 19 de julho de 2016, que estabelece o conceito de "cidades-gêmeas" nacionais, os critérios adotados para essa definição e lista todas as cidades brasileiras por Estado que se enquadram nesta condição. Diário Oficial da Uniáo, Brasília, 29 abr. 2019. Disponível em: <https://www.in.gov.br/web/dou/-/portaria-n\%C2\%BA-1.080-de24-de-abril-de-2019-85673267>. Acesso em: 20 set. 2020. 
CARDOSO, N. A.; MOURA, R. Regiôes de fronteira e fluxos migratórios: o caso do Paraná. In: PENHA, B.; DESIDERÁ NETO, W. A.; MORAES, R. F. (Org.). O Mercosul e as regióes de fronteira. Rio de Janeiro: Ipea, 2017. p. 53-100.

DESCHAMPS, M.; DELGADO, P.; MOURA, R. Mobilidade pendular na faixa de fronteira brasileira: particularidades dos arranjos transfronteiriços. In: PÊGO, B.; MOURA, R. (Org.). Fronteiras do Brasil: uma avaliação de política pública. Rio de Janeiro: Ipea, 2018. v. 1. p. 293-321.

EGLER, C. A. G. Referenciais básicos para uma metodologia de identificação do sistema urbano da América do Sul. In: FURTADO, B.; PÊGO, B. (Coord.). Rede urbana e integraçáo produtiva no Brasil e na América do Sul. Brasília: Ipea; Cepal; Ipardes, 2015. (Relatório de Pesquisa).

IBGE - INSTITUTO BRASILEIRO DE GEOGRAFIA E ESTATÍSTICA. Arranjos populacionais e concentraçóes urbanas no Brasil. 2. ed. Rio de Janeiro: IBGE, 2016.

Regióes de Influência das Cidades 2018. Rio de Janeiro: IBGE, 2020. Disponível em: <https://biblioteca.ibge.gov.br/visualizacao/livros/liv101728.pdf>. Acesso em: 30 jul. 2020.

MOURA, R.; OLIVEIRA, S. Referências sobre a faixa de fronteira e os arranjos transfronteiriços do Brasil. In: PÊGO, B.; MOURA, R. (Org.). Fronteiras do Brasil: uma avaliaçâo de política pública. Rio de Janeiro: Ipea, 2018. v. 1. p. 243-292.

PÊGO, B. et al. Fronteiras do Brasil: referências para a formulação de políticas públicas para as fronteiras brasileiras. Brasília: Ipea; MDR, 2021. v. 6.

PÊGO, B.; MOURA, R. (Org.). Fronteiras do Brasil: uma avaliação de política pública. Rio de Janeiro: Ipea, 2018. v. 1. 



\title{
PARA FICAR EM CASA É PRECISO TER CASA: A COVID-19 E O DIREITO À MORADIA NO BRASIL ${ }^{1}$
}

\author{
Nino Rafael Medeiros Krüger ${ }^{2}$ \\ Caroline Krüger ${ }^{3}$ \\ Gustavo Henrique Soares Ferreira ${ }^{4}$
}

\section{INTRODUÇÃ $0^{5}$}

O "novo coronavírus, denominado Sars-CoV-2, causador da doença Covid-19", que acarreta infecçôes respiratórias com alta capacidade de contágio e efeitos letais (Lana et al., 2020, p. 1), ainda não possui cura ou sequer um tratamento eficaz no impedimento de sua contaminação. Com rápida disseminação em escala global, ${ }^{6} \mathrm{o}$ vírus colocou em xeque as estratégias historicamente adotadas para o trato com as diversas dimensóes da questáo social - compreendida enquanto desdobramento do conflito entre capital e trabalho nas sociedades capitalistas (Iamamoto, 2001), em especial com a questão da habitação.

Isso porque, devido ao fato de a capacidade dos sistemas de saúde em lidar com a taxa de contaminação pelo vírus no curto prazo ser limitada e os recursos, finitos (leitos hospitalares, número de profissionais de saúde, entre outros), o número de pacientes tratados tornou-se menor que a demanda necessária (Silva, 2020, p. 579). Essa realidade deixou muitos pacientes infectados com condiçóes pulmonares deterioradas sem nenhum tratamento, resultando na necessidade de políticas drásticas de distanciamento físico (Gourinchas, 2020).

Em outras palavras, a recomendação "fique em casa", que partiu de lideranças internacionais, entre as quais se destaca a OMS, tornou-se slogan da campanha contra a disseminação da Covid-19. Contudo, como ficar em casa quando náo se tem moradia, ou ainda quando suas condiçóes são precárias?

1. DOI: http://dx.doi.org/10.38116/brua24art9.

2. Pesquisador doutorando em políticas sociais e direitos humanos na Universidade Católica de Pelotas (UCPel).

3. Pesquisadora doutora lotada na pesquisa Fronteiras do Brasil: uma Avaliação de Política Pública, desenvolvida pela Diretoria de Estudos e Políticas Regionais, Urbanas e Ambientais (Dirur) no Ipea.

4. Pesquisador doutorando lotado na pesquisa Fronteiras do Brasil: uma Avaliação de Política Pública, desenvolvida pela Dirur/lpea. 5. Os autores agradecem a leitura atenta, os comentários e as sugestões do parecerista anônimo que possibilitaram ajustes fundamentais à estrutura e ao conteúdo do texto.

6. 0 vírus foi detectado em 31 de dezembro de 2019 em Wuhan, na China, e em 16 de janeiro em território japonês. Em 30 de janeiro, foi declarado pela Organização Mundial da Saúde (OMS) como emergência internacional (Public Health Emergency of International Concern - Pheic), quando diversos países já haviam confirmado importações de caso, incluindo Estados Unidos, Canadá e Austrália. No Brasil, em 7 de fevereiro, havia nove casos em investigação (Lana et al., 2020). 
No Brasil, a moradia é um direito e um bem fundamental ao desenvolvimento seguro e saudável da vida humana, segundo a Constituição Federal de 1988 (CF/1988) (Brasil, 1988). Porém, aqueles que a acessam de forma precária, ou seja, os habitantes de áreas irregulares, que se caracterizam entre $50 \%$ e $60 \%$ da população brasileira (Ribeiro, 2019; Cunha, 2019), acabam se tornando os alvos principais do contágio e da transmissão da Covid-19 (Srougi, 2020). Esse cenário impinge a necessidade de campanhas que não só impulsionem o isolamento social mas o subsidiem, garantindo-o enquanto direito.

Com esse escopo, este ensaio discute a disseminação da Covid-19 a partir da reflexão sobre o direito à moradia no Brasil. Para isso, além desta breve introdução, são recuperadas questôes históricas e se apresenta uma análise sobre o tema utilizando-se dados do censo demográfico de 2010 (IBGE, 2011), dados preliminares do censo de 2019 (IBGE, 2019), além de dados da Fundação Oswaldo Cruz (Fiocruz) sobre a Covid-19 de 31 de julho de 2020 (Fiocruz, 2020). Finaliza-se o texto nas consideraçóes finais, com apontamentos para a efetivação de políticas públicas sobre o tema.

\section{DIREITO À MORADIA NO BRASIL E A COVID-19}

Internacionalmente, a questão da moradia se tornou objeto de intensas reflexôes e calorosos debates que a lançaram ao âmbito dos direitos fundamentais há mais de meio século. Todavia, mesmo diante de inúmeras conferências, tratados e acordos que abordam o tema e têm a nação brasileira enquanto signatária, esse direito, e o complexo arcabouço dos temas que o envolvem (segurança, infraestrutura, economicidade, habitabilidade, acessibilidade, adequação cultural, localizaçáo etc.), continua a ser ofertado apenas a uma parcela da população, sendo oferecido enquanto bem de consumo (Maricato, 2013), negando sua essência enquanto direito fundamental (Kruger, 2018).

Esse é o cenário que se apresenta e molda a arena sobre a qual se dissemina a Covid-19 no Brasil. Desvela que o modelo de desenvolvimento social que vem há séculos preconizando o econômico, em detrimento do social e ambiental, não suporta mais a vida (Araújo, Mallart e Gaudenzi, 2020). Na natureza mercantilizada no espaço urbano financeirizado, coisificou-se a vida, que agora se expressa enquanto números que rapidamente se perdem, pois a histórica negação do acesso a direitos fundamentais para parte substantiva da população, cedo ou tarde, recai sobre o todo o social.

Diante da pandemia, o apelo "fique em casa" busca chamar a atenção da população mundial para a necessidade da prática do isolamento físico enquanto estratégia voltada ao impedimento da proliferação rápida da Covid-19, que incorreria em colapso dos sistemas de saúde. Contudo, quando ecoado sobre a nação brasileira, acaba se tornando declaração de denúncia da violência da qual essas populaçôes vulneráveis têm sido vítimas por séculos, uma vez que, anteriormente, não tiveram tal direito garantido e agora lhes é cobrado um preço diante do avanço da contaminação.

No lastro colocado por Penalva e Duarte (2010), assevera-se aqui que, diante do tamanho do problema enfrentado, lançar reflexáo sobre a origem dessa crise referente à moradia no país se torna uma questáo necessária. Isso porque se observam processos de violência e expulsôes desde a chegada dos invasores portugueses no século XV, quando se iniciam as exploraçôes de recursos naturais tornados em bens de consumo para a impulsão de economias de outras latitudes. Visando à reduçáo do marco temporal, recuperam-se processos desencadeados pela chegada da coroa portuguesa em 1808. A coroa, ao vir acompanhada de uma corte de aproximadamente 15 mil pessoas para as quais não fora preparada previamente a alocaçáo, 
deu início a um processo de desapropriação e expulsão que vitimou substantiva parcela da população, como afirmavam Penalva e Duarte (2010, p. 3), ao retratar que

o problema de acomodar tamanho contingente populacional foi resolvido com a "requisiçáa", pela coroa, das melhores residências da sede da então colônia. A marca "P. R." era a identificação de que a residência tinha sido requisitada. Essa era a marca de "príncipe regente", mas a população logo passou a se referir a ela como "ponha-se na rua", o que, convenhamos, correspondia mais aos fatos.

É um processo violento, que marca a gênese de um problema que se agrava no decorrer dos anos, pela materialização de um modelo de desenvolvimento urbano que não foi pensado para respeitar as características socioculturais locais (Kruger et al., 2020). A sançáo da Lei $\mathrm{n}^{\circ}$ 601/1850, a Lei de Terras (Brasil, 1850), colocou-se enquanto elemento fundamental para o aprofundamento desse processo.

A institucionalização da negação do acesso a terra, bem fundamental para o desenvolvimento e a manutenção da vida, alicerçou a estrutura necessária para o subjugamento e a expulsão daqueles que não têm ao seu alcance recursos suficientes para resistir às açôes dos grupos economicamente dominantes (Holz e Monteiro, 2008). Um segundo processo (Silva, 1996), responsável pela configuração de um desenho de ocupação do solo, se deu de forma desigual e antidemocrática, e para ele instituíram-se instrumentos maniqueístas, os quais acabaram por transformar o Estado em vetor de captura para a potencialização da segregação e do arbítrio.

A proteção da propriedade privada em detrimento da vida deu sustentação a um modelo de exploraçáo voltado ao aprofundamento da acumulação de capitais. Políticas pautadas por valores de mercado operam desde entáo, subordinando trabalhadores a partir da disseminação de racionalidades apresentadas como sendo a única forma possível para o alcance da tão sonhada ordem e progresso (Morais, 2002). Uma razão que traduz a ideologia ilusória de "bem-estar" coletivo, possibilitando que o Estado se torne uma instância de socorro para o mercado.

As normas jurídicas nesse cenário passam a estabelecer conjuntos de regras para a adaptaçáo das estratégias dessa regulaçáo, e o direito à moradia, discutido em congressos e conferências, publicado em relatórios, é transformado em norma de adequação (PDHJ, 2009; Brasil, 2013) que materializa o controle da sociedade para a manutençáo do modo de produção. Sua concretização constitui uma arena de tensôes sobre a qual se desenham os conflitos que mantêm em expansão o sistema posto (Kruger, 2020).

Assim, são historicamente definidas e planificadas as políticas habitacionais no Brasil. Tal situaçáo recupera as estratégias do Estado no século XIX, que se voltava à garantia dos interesses das elites ruralistas, até o alargamento dos objetivos do mercado da construçáo civil a partir da década de 1960, quando a ideologia da casa própria se torna meta do regime militar, o qual sequestra recursos dos trabalhadores por meio dos fundos de garantia para transferência direta às elites que dominam o mercado construtor (Silva, 1989), definindo o desenho urbano atual. Nesse desenho, quanto menores forem os recursos financeiros da população, mais latente fica a situaçáo de vulnerabilidade, colocando tais grupos em áreas cada vez mais distantes dos centros urbanos, estabelecendo-se marcadores de acesso a infraestrutura, equipamentos, bens e serviços que configuram a violação ao direito à moradia e à cidade (Kruger, 2020).

Uma janela para a reconfiguração dessa estrutura foi vislumbrada com a promulgação do Estatuto da Cidade (Brasil, 2001), com a criação do Ministério das Cidades e dos conselhos com participação popular (Brasil, 2003). Entretanto, o desenvolvimento do 
programa Minha Casa Minha Vida (Brasil, 2009) desconectado das discussóes do Plano Nacional de Habitação (PlanHab), que vinha sendo construído desde 2004, reforçou os processos anteriores, em que recursos expropriados de fundos públicos foram utilizados para salvar o mercado (Nabuco, Primi e Nabuco, 2014). Valores que deveriam ser destinados ao desenvolvimento de políticas sociais como seguridade social, políticas de assistência, saúde e educação passaram a ser transferidos para os construtores (Rodrigues e Salvador, 2011).

Desse modo, impóe-se a necessidade do desenvolvimento de reflexáo crítica sobre as estratégias adotadas para o trato com as diversas dimensóes da questão social - contexto no qual se insere a questáo habitacional, negada enquanto direito e bem fundamental ao desenvolvimento seguro e saudável da vida. Aqueles que não têm acesso à moradia ou que a acessam de forma irregular ou precária se tornaram alvos potenciais do vírus.

Cabe destacar que, no período de governo do ex-presidente Michael Temer, se reafirmou o compromisso do Estado com o setor privado da construção, e se aprofundaram processos de negação de direitos aos grupos historicamente desprotegidos (Kruger, 2020). Esses fatos foram materializados na diminuição dos recursos para a linha do Minha Casa Minha Vida direcionada aos grupos de baixa renda, na criação de uma nova modalidade do programa voltada ao mercado (Souza e Hoff, 2019) e na promulgação da Emenda Constitucional no 5 também conhecida como Emenda Constitucional do Teto dos Gastos Públicos, alterou a CF/1988 ao instituir o Novo Regime Fiscal, congelando por vinte anos os investimentos que deveriam ocorrer em habitação, saúde, educação (Brasil, 2016).

Uma situação ainda mais complexa se deu no atual governo, em que os espaços institucionais de participação popular foram eliminados, extinguiu-se o Ministério das Cidades - uma conquista histórica dos movimentos populares que lutam pela reforma urbana - e funcionários de carreira desse ministério foram alocados em cargos subalternos (Brasil, 2019). Além disso, ele foi fundido com o Ministério da Integração, resultando no Ministério do Desenvolvimento Regional (MDR). Foram cancelados também os recursos para os projetos de habitação de interesse social (grupos de baixa renda) e aprofundou-se a precarização nas condiçôes de moradia, que agora vem à tona de forma indelével (Kruger, 2020).

Nesse cenário, a convocação "fique em casa”, ao se deparar com uma nação estruturada sobre o trato da moradia enquanto objeto de mercado, artigo colocado à disposiçáo somente daqueles que têm como arcar financeiramente com seus custos, acaba expondo a tática de controle socioterritorial da população, por meio dos marcadores de diferenciação social (Pina, 2018). O acesso à moradia pelo mercado acaba funcionado enquanto fronteira que delimita os espaços de promoção da infraestrutura urbana, selecionando aqueles que serão alvo da proteção social dos demais. Isso é parte de um processo que manifesta a tragédia que as cidades se tornaram (Rolnik, 2015), onde a moradia para substantiva camada da populaçáo não pode ser considerada refúgio ou espaço de garantia de segurança contra a pandemia (Alfonsin, 2020).

Assim, à medida que o vírus se propaga no país e alcança as cidades com baixos índices de infraestrutura urbana, como nos casos registrados nos estados do Norte (mapas 1A e 1B), bem como nas comunidades periféricas (Bombardi e Nepomuceno, 2020), ele vai alterando o que se tem considerado internacionalmente enquanto grupos de risco. ${ }^{7}$ Isso ocorre porque, primeiramente, a letalidade do vírus estava "majoritariamente associada a pacientes idosos ou à presença de comorbidades que afetam o sistema imunológico" (Lana et al., 2020, p. 2),

7. Disponível em: <https://bit.ly/3g2pgnH>. 
passando a vitimar as periferias das cidades, onde habita grande parte da população excluída no processo de urbanização (Srougi, 2020).

À vista disso, verifica-se que a coabitação, o ônus excessivo de aluguel, os altos índices de adensamento populacional em áreas onde falta infraestrutura urbana básica (mapas 1C e 1D), os aglomerados sem acesso a saneamento, calçamento, água, como também apontam os dados dos aglomerados subnormais do censo do Instituto Brasileiro de Geografia e Estatística (IBGE), imprimem o marcador de risco nos corpos que esses territórios habitam.

\section{MAPA 1}

\section{Infraestrutura urbana}

1 A - Percentual de domicílios com abastecimento de água e esgotamento sanitário inadequados

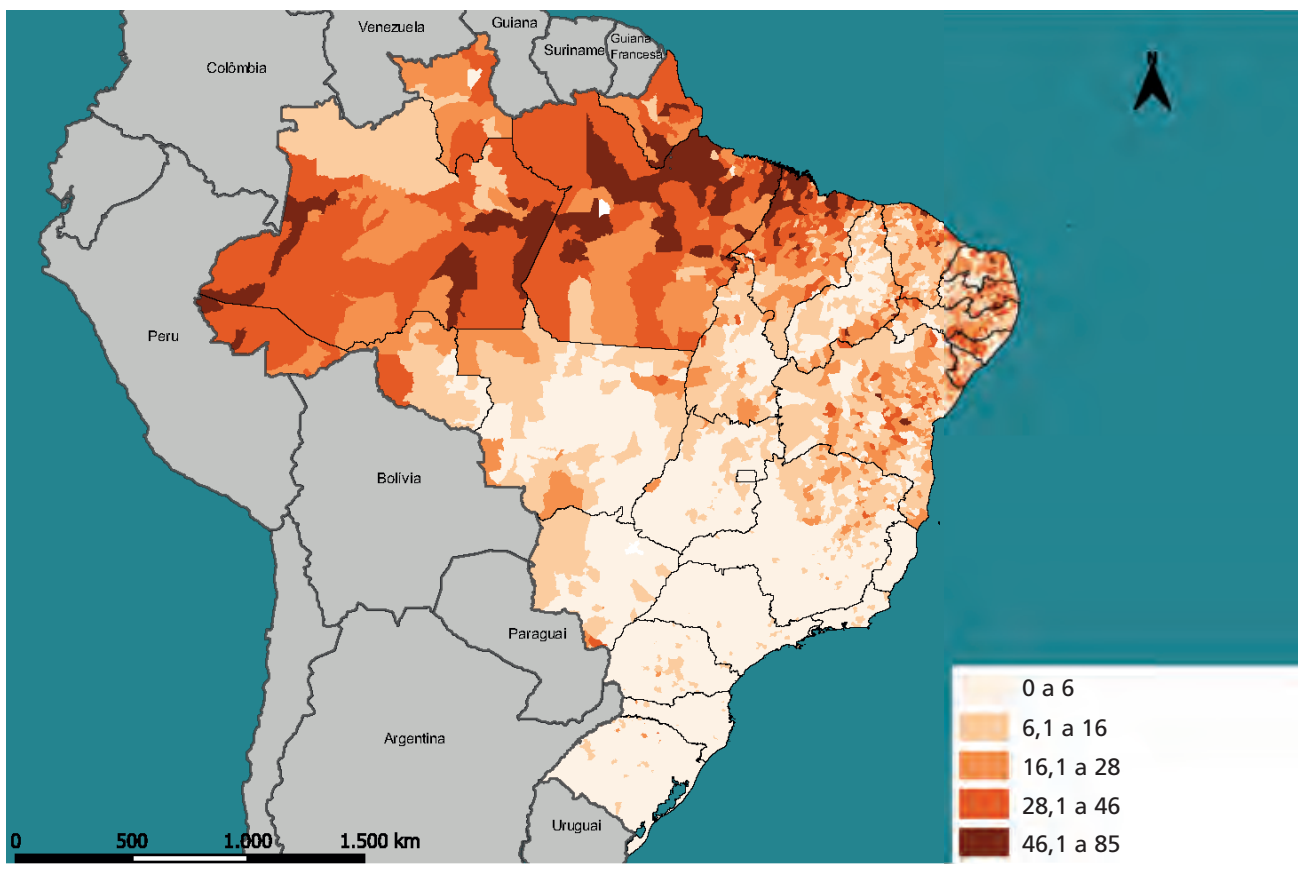

1B - Percentual de domicílios sem o serviço de coleta de lixo

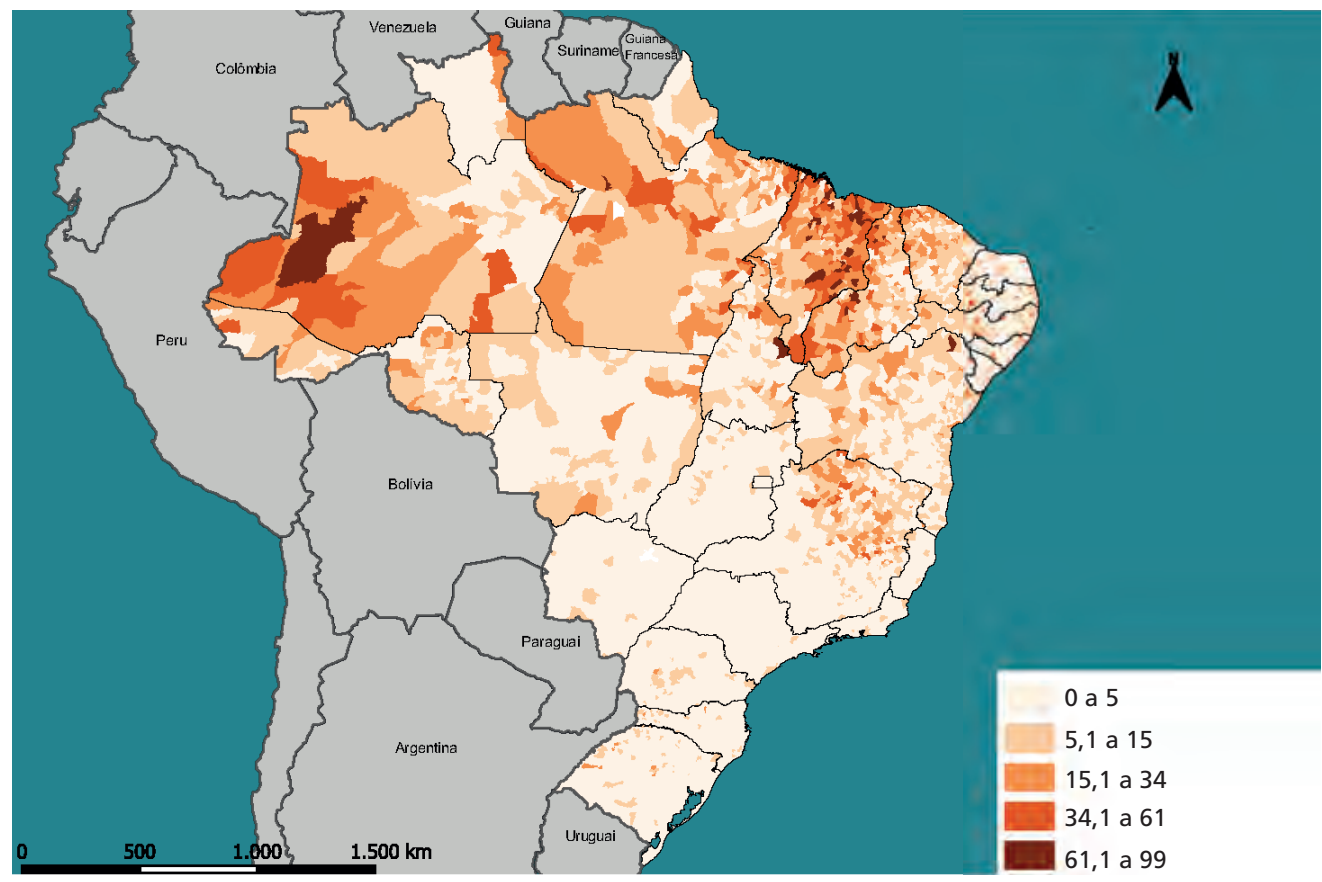


1C - Média de moradores por domicílio

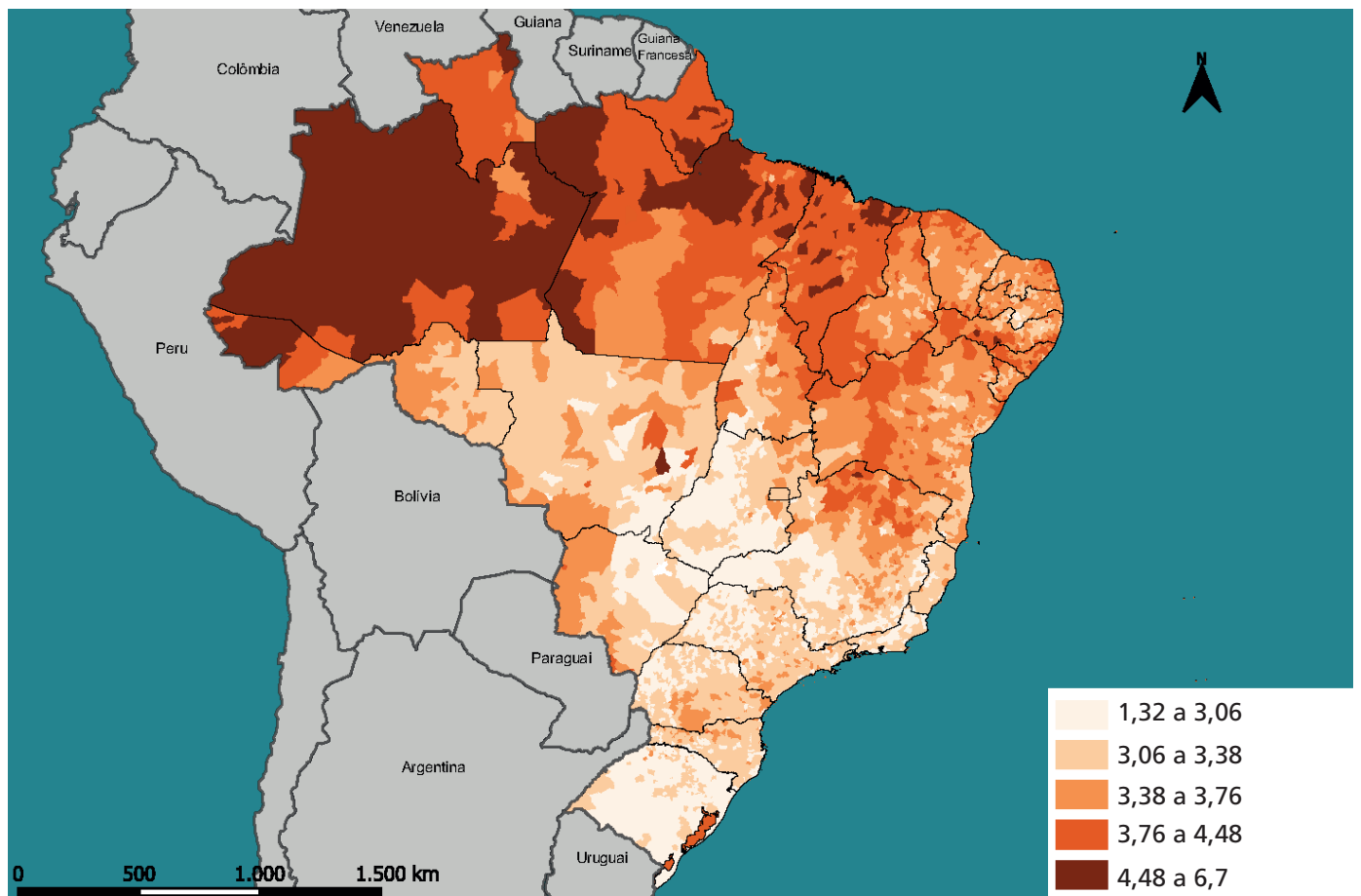

1D - Média de moradores por dormitório

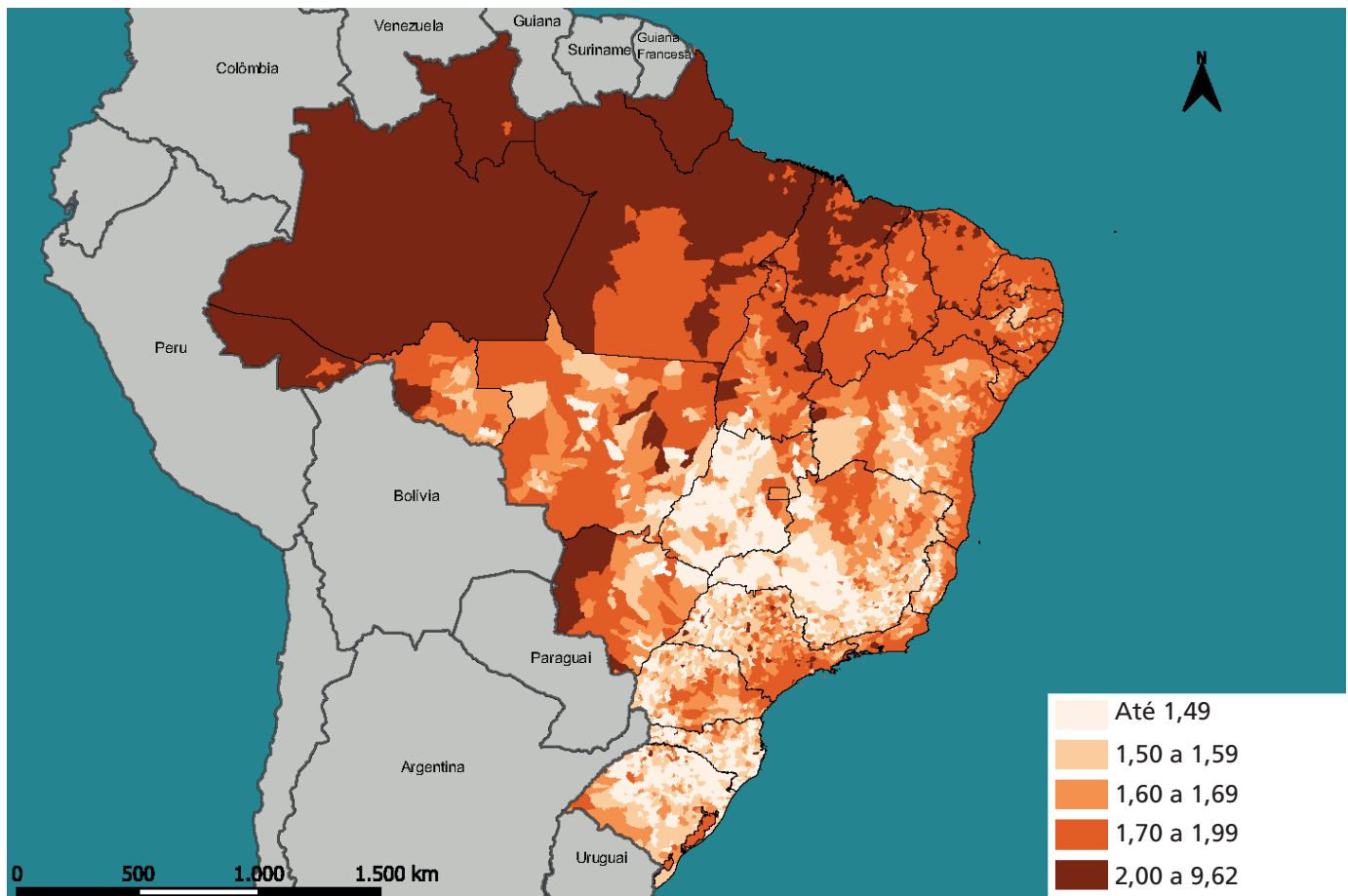

Fonte: IBGE (2011)

Elaborado pelos autores.

Nesse ínterim, outro dado relevante se refere ao impacto da Covid-19 nas periferias brasileiras, pois, ao analisar esses resultados, percebe-se que os óbitos nos espaços sem infraestrutura urbana chegam a ser oito vezes maiores que nos bairros providos desse serviço (Carvalho, 2020) (mapas 2A e 2B). Além disso, os marcadores de escolaridade e raça, que delimitam uma condição socioeconômica estrutural na sociedade, são potencializadores dos riscos (Agência Pública, 2020; Costa, 2020). Complementarmente, segundo a organização 
não governamental (ONG) Rede Nossa São Paulo, no Brasil, o fator de risco para que a Covid-19 seja letal é o endereço, estando a falta de infraestrutura básica para habitação e higiene relacionada diretamente com as taxas de mortalidade do vírus.

MAPA 2

Covid-19: incidência de casos, óbitos e estabelecimentos de saúde 2A - Incidência de casos por 1 milhão de habitantes (31 jul./2020)

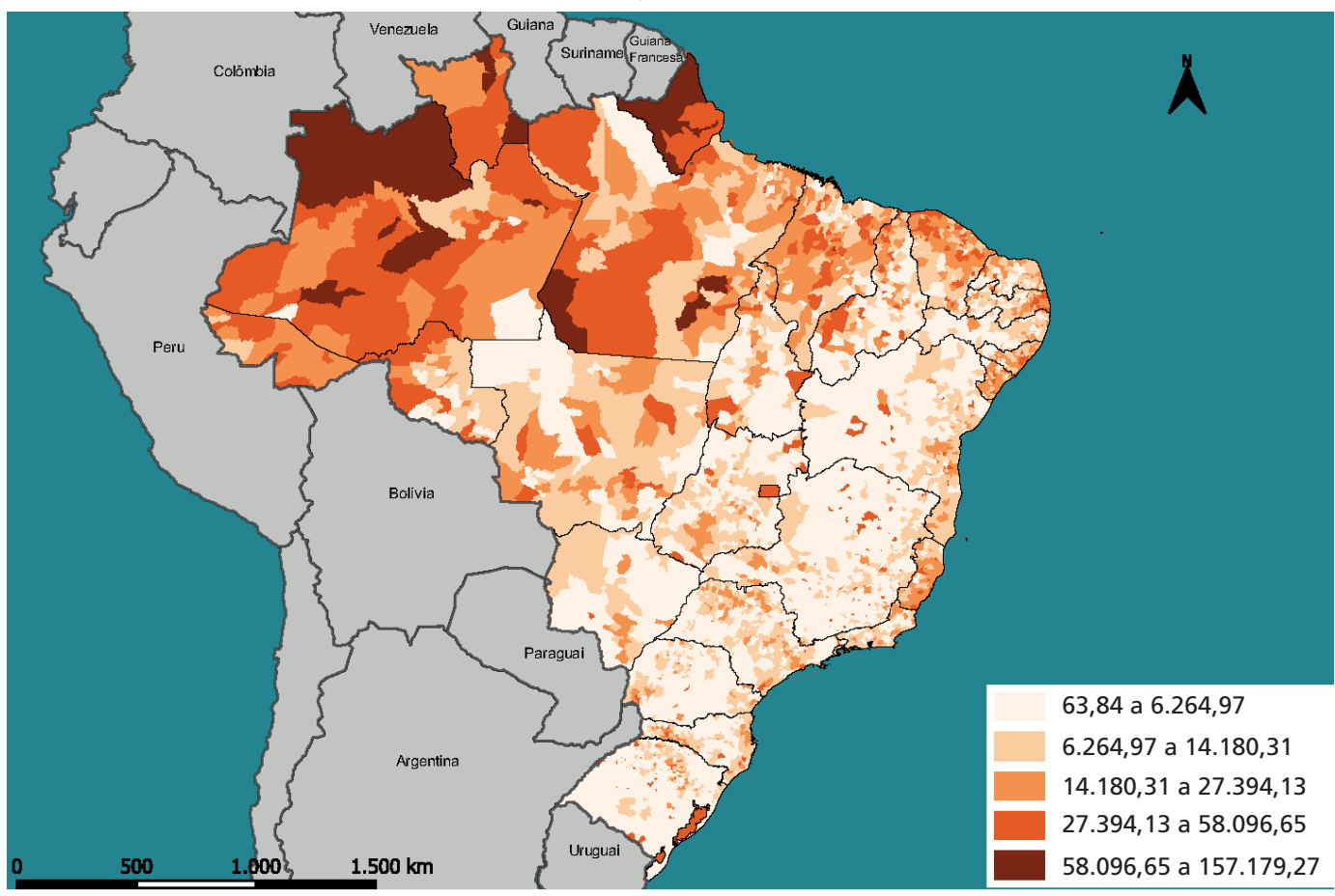

2B - Incidência de óbitos por 1 milhão de habitantes (31 jul./2020)

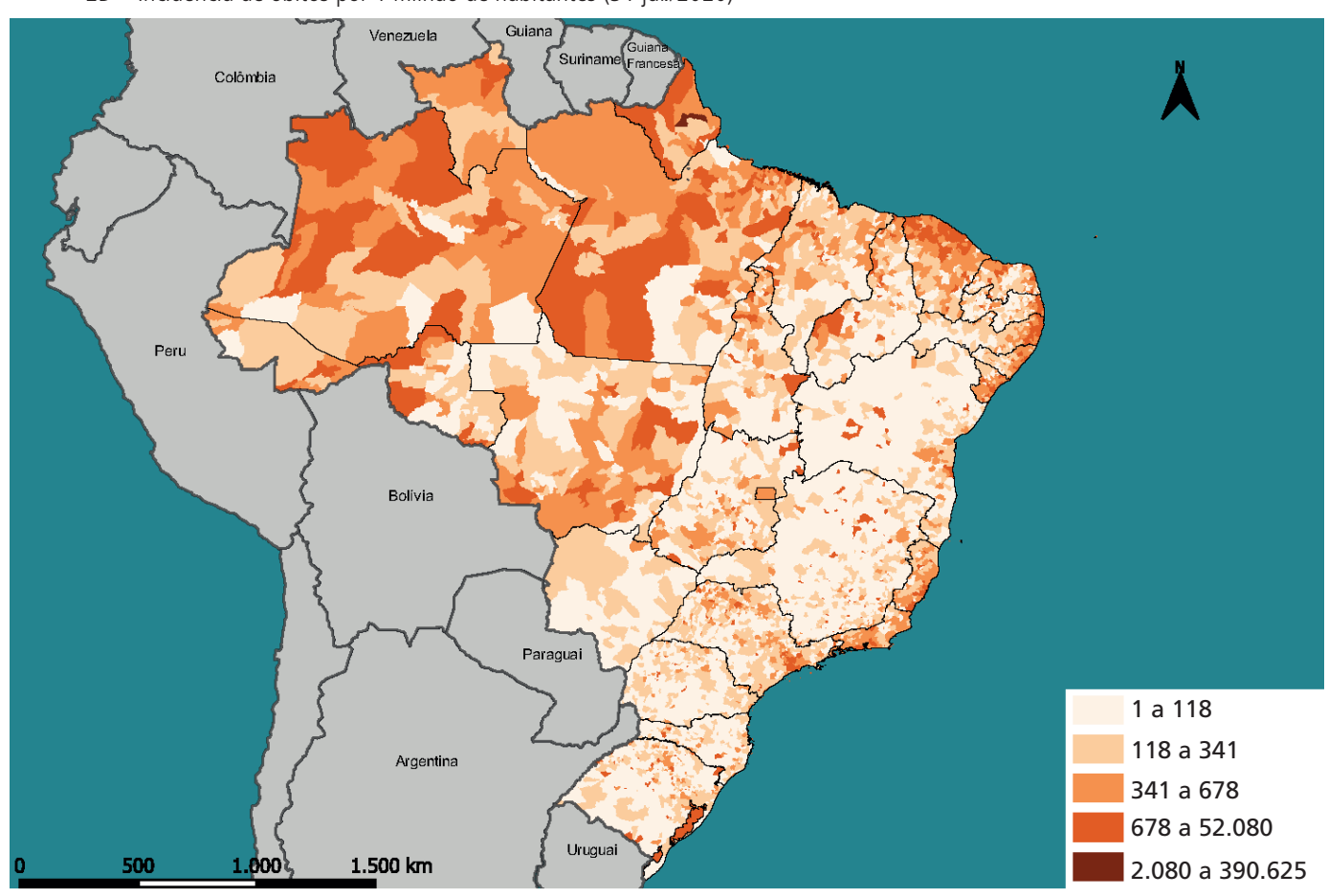


2C - Estabelecimentos de saúde de atenção primária

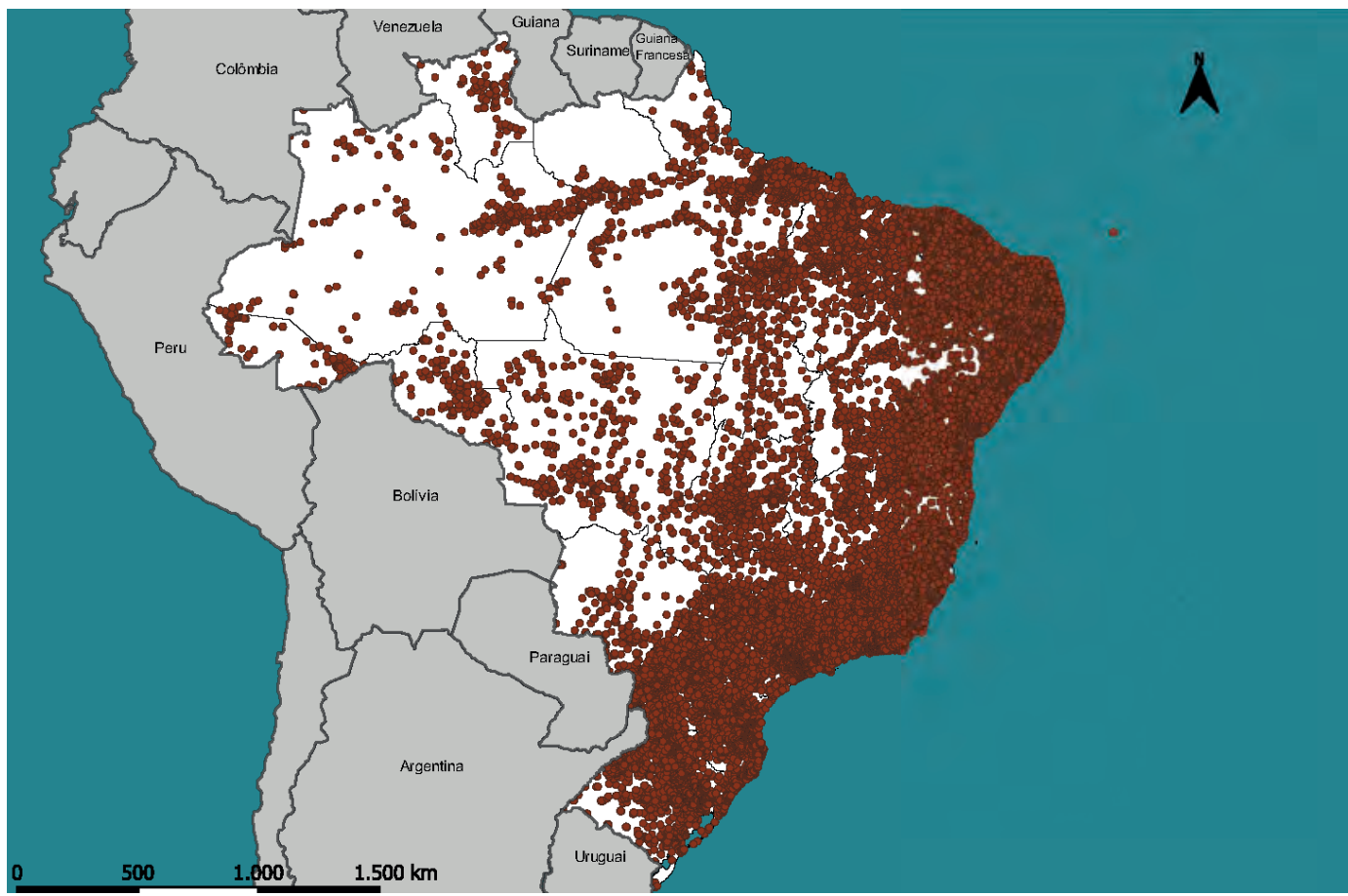

2D - Estabelecimentos de saúde com suporte de observação e internação

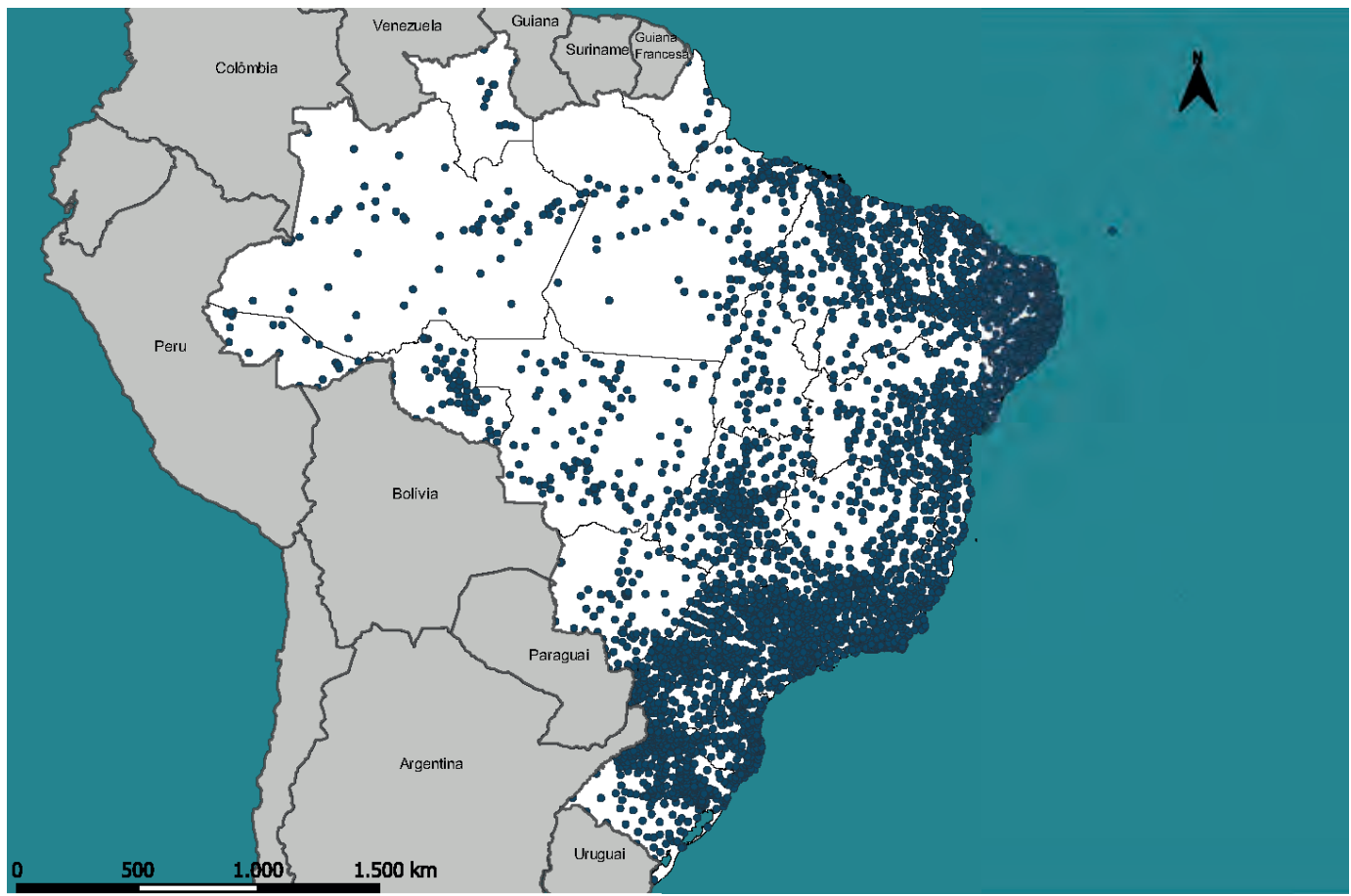

Fonte: Fiocruz (2020)

Elaborado pelos autores.

Importante ainda ressaltar que o encontro de uma crise econômica com uma "outra política" resultou no desmonte das políticas urbanas para o país (Vainer, 2013), que, ao se confrontarem com a pandemia, tornaram explícita a desigualdade socioterritorial urbana brasileira, reverberando na premência de medidas para o fortalecimento do sistema de proteção social. Esse sistema, por sua vez, vem sofrendo, ao longo dos últimos anos, pesadas 
reduções orçamentárias, como no caso já citado do congelamento de gastos primários por meio da Emenda Constitucional no 95 (Brasil, 2016).

Em decorrência da redução orçamentária, um preço muito alto frente à proliferação do vírus tem sido pago, uma vez que grande parcela das cidades brasileiras possui deficit de estabelecimentos de atenção básica de saúde e de estabelecimentos de saúde com suporte de observação e internação (mapas 2C e 2D), tornando precária a capacidade de atendimento e o suporte no cenário pandêmico.

Ainda que nos atestados de óbito das vítimas dessa crise civilizacional encontre-se marcado "morte por coronavírus", na maioria dos casos, o que as terá matado é a negligência - o Estado, muitas vezes, em detrimento da proteção de seus cidadáos, volta-se para o mercado, concedendo a ele todos os benefícios possíveis por meio da subtração de recursos/direitos dos grupos vulneráveis. A análise dos relatórios do Plano de Aceleração do Crescimento (PAC) que tratam do programa Minha Casa Minha Vida (Brasil, 2014; 2018) apresenta um panorama de tal inversão de prioridades no ato da planificação de políticas públicas. Esses relatórios demonstram que, mesmo se reconhecendo que o deficit habitacional no país se encontra substancialmente entre os grupos com renda inferior a três salários mínimos - 89\%, faixa de renda tida como prioridade do programa (Brasil, 2009) -, os investimentos para a produção de moradias para os grupos encontrados acima dos três salários mínimos foram de mais de 60\% do orçamento (Chiarelli, 2014; Brasil, 2018).

Um tema em discussão que poderia corroborar a melhoria deste cenário é a reforma tributária no Brasil. Segundo o último Relatório de Desenvolvimento Humano da Organização das Naçôes Unidas (ONU), ${ }^{8}$ no Brasil, o $1 \%$ mais rico concentra quase um terço da renda de quase $30 \%$ da população, o que dá ao país o título de vice-campeão mundial em desigualdade, só perdendo por $0,7 \%$ para o Catar. Além disso, cinco bilionários brasileiros concentram a mesma riqueza que a metade mais pobre do país, segundo estudo da Oxfam Brasil, ${ }^{9}$ ou seja, cinco pessoas concentram o mesmo patrimônio que 100 milhóes de brasileiros.

Essa é a situação que a Covid-19 desnuda, ao apresentar-se enquanto um vírus trazido ao país por pessoas economicamente privilegiadas, e tornar mais vulneráveis a seus riscos aqueles que, sem alternativa, têm de se entregar ao serviço desses. As principais vítimas da pandemia permanecem sendo as históricas vítimas dessa estrutura.

\section{CONSIDERAÇÕES FINAIS: DIRECIONAMENTOS PARA POLÍTICAS PÚBLICAS}

No momento em que as autoridades sanitárias internacionais apontam para a necessidade do isolamento físico como estratégia para o impedimento da proliferação do vírus, e destacam a importância de hábitos de higiene, grupos que não têm direito a saneamento e moradia sáo mantidos em áreas com precária infraestrutura urbana, sendo impedidos de se proteger adequadamente. Sáo milhares os assentamentos irregulares em que esses grupos sofrem por conta do adensamento populacional, espaços que não possuem abastecimento de água potável regular.

Essa situação torna urgente a reflexão sobre a realidade na qual a violação de direitos positivados, como a "garantia do direito a cidades sustentáveis, entendido como o direito à terra urbana, à moradia, ao saneamento ambiental, à infraestrutura urbana, ao transporte e aos serviços públicos, ao trabalho e ao lazer, para as presentes e futuras geraçóes" (Brasil,

8. Disponivel em: <https://bit.ly/3fhZZ8s >.

9. Disponível em: <https://bit.ly/3yxR5eR>. 
2001), deixa mais de $60 \%$ da população sem acesso a tratamento de esgoto (Ipea, 2016). Esse cenário estabelece um panorama potente para a ampliação da contaminação pela Covid-19.

Verifica-se que a busca pela garantia do direito a uma moradia digna se entrelaça à conquista do direito à cidade - um direito coletivo que engloba variados aspectos dos direitos urbanos -, compreendido pelo relatório do Ipea para o Habitat III como um novo paradigma para repensar os processos de urbanização e as cidades brasileiras, voltado ao cumprimento de todos os direitos humanos que outrora foram acordados internacionalmente (Ipea, 2016). Assim, a garantia desse direito, conforme exposto na legislação brasileira, deveria transformar a situação dos grupos atualmente mantidos sem acesso à moradia, processo que é resultado de décadas de violação/omissão por parte dos governantes em todas as esferas e entes da Federação.

Para que o isolamento físico, uma das principais recomendaçôes das autoridades sanitárias para o enfrentamento da pandemia, possa ocorrer adequadamente para a população em situação de vulnerabilidade, é primordial que os instrumentos que garantem a função social da propriedade constantes dentro da legislação sejam colocados em ação. Dessa maneira, os governos municipais passariam a utilizar, durante o período pandêmico, para tais grupos, a requisição administrativa de imóveis abandonados, não utilizados pelo poder público municipal, e até mesmo quartos de hotel. Esse instrumento se fundamenta no art. 5, inciso XXV, da $\mathrm{CF} / 1988$, que descreve que, "no caso de iminente perigo público, a autoridade competente poderá usar de propriedade particular, assegurada ao proprietário indenização ulterior, se houver dano" (Brasil, 1988).

Para tanto, entende-se necessário um maior comprometimento por parte do poder público na esfera municipal, que deve adotar uma postura proativa diante da realidade vivenciada no país, reconhecendo as ocupaçóes em áreas públicas e terrenos que não cumprem função social enquanto estratégias para a garantia da proteção contra o vírus, que se constitui, neste contexto, um direito. Ademais, entende-se que podem ser desenvolvidos programas de incentivo à doação de materiais de construção e à elaboração de bancos de matérias, para a disponibilização a famílias que sofrem com o problema da coabitação, além de bancos de terras, a partir do mapeamento de terras públicas e privadas que não cumprem função social e podem ser alvo de desapropriação - conforme o inciso XXIV do art. 5o da CF/1988 (Brasil, 1988).

A cobrança de Imposto sobre a Propriedade Predial e Territorial Urbana (IPTU) de forma progressiva, constante, na mesma legislação e que se volta ao desestímulo da manutenção de propriedades improdutivas poderia servir para a criaçáo de recursos para o desenvolvimento de programas de aluguel social para famílias desprotegidas. Para os casos de remoçôes ou reintegraçóes de posse, aponta-se a necessidade de serem criadas câmaras de conciliaçáo, previstas no art. 34 da Lei no 13.465 (Brasil, 2017), para a mediação dos processos e a garantia dos direitos das populaçôes. Do mesmo modo, precisa-se da suspensão das reintegraçôes de posse e despejo no período da pandemia, bem como da criação de protocolos de remoção, para a garantia de direitos das populaçóes vitimadas por tais processos fora do período pandêmico. Sobre os despejos, cabe destacar ainda a necessária implementação da proposta de quarenta entidades do Brasil e do exterior, que se uniram e lançaram a campanha Despejo Zero em julho de 2020 (Lacerda, 2020). Essa ação está voltada à suspensão de atividades que violem direitos, sejam fruto de açóes despendidas por entes privados ou públicos, que tenham respaldo em decisóes judiciais ou administrativas e que objetivem desabrigar famílias e comunidades no período da pandemia. 


\section{REFERÊNCIAS}

AGÊNCIA PÚBLICA. Em duas semanas, número de negros mortos por coronavírus é cinco vezes maior no Brasil. Carta Capital, 7 maio 2020. Disponível em: <https://bit.ly/2QPezLm>. Acesso em: 8 maio 2020.

ALFONSIN, B. de M. A tutela do direito à cidade em tempos de Covid-19. Observatório das Metrópoles, 2020. Disponível em: <https://bit.ly/3hUz9VF>. Acesso em: 21 ago. 2020.

ARAÚJO, F.; MALLART, F.; GAUDENZI, P. Contextualizar o desmonte é essencial. Labcidade, jul. 2020. Disponível em: <https://bit.ly/3vohtpy>. Acesso em: 21 ago. 2020.

BOMBARDI, M. L.; NEPOMUCENO, P. L. M. Covid-19, desigualdade social e tragédia no Brasil. Le Mond Diplomatique Brasil, 29 abr. 2020. Disponível em: <https://bit.ly/3w3csTl>. Acesso em: 7 jun. 2021.

BRASIL. Lei no 601, de 18 de setembro de 1850. Dispóe sobre as terras devolutas do Império. Collecção das Leis do Imperio do Brazil, 1850. Disponível em: <https://bit.ly/2SIS2pY>. Acesso em: 24 abr. 2018.

Constituição da República Federativa do Brasil de 1988. Brasília: Senado Federal, 1988. Disponível em: <https://bit.ly/3viS6W0>. Acesso em: 12 ago. 2020.

. Lei no 10.257 , de 10 de julho de 2001. Regulamenta os arts. 182 e 183 da Constituição Federal, estabelece diretrizes gerais da política urbana e dá outras providências. Diário Oficial da Uniâo, Brasília, 11 jul. 2001. Disponível em: <https://bit.ly/2RHzv7q>. Acesso em: 9 out. 2017.

. Lei no 10.683 , de 28 de maio de 2003. Dispóe sobre a organização da Presidência da República e dos ministérios, e dá outras providências. Diário Oficial da União, Brasília, 29 maio 2003. Disponível em: <https://bit.ly/3ujkKoH>. Acesso em: 6 jun. 2018.

. Lei no 11.977 , de 7 de julho de 2009. Dispóe sobre o Programa Minha Casa Minha Vida - PMCMV e a regularizaçấo fundiária de assentamentos localizados em áreas urbanas; altera o Decreto-Lei no 3.365, de 21 de junho de 1941, as leis nos 4.380, de 21 de agosto de 1964, 6.015, de 31 de dezembro de 1973, 8.036, de 11 de maio de 1990, e 10.257, de 10 de julho de 2001, e a Medida Provisória no 2.197-43, de 24 de agosto de 2001; e dá outras providências. Diário Oficial da União, Brasília, 8 jul. 2009. Disponível em: <https://bit.ly/2RA9N4T>. Acesso em: 9 out. 2017.

- Secretaria de Direitos Humanos da Presidência da República. Direito à moradia adequada. Brasília: Coordenação Geral de Educação em SDH/PR, Direitos Humanos, Secretaria Nacional de Promoção e Defesa dos Direitos Humanos, 2013. Disponível em: <https://bit. ly/3hOzVU2>. Acesso em: 29 set. 2017.

PAC2: a gente faz um Brasil de oportunidades - balanço 4 anos (2011 a 2014). [s.l.]: [s.n.], 2014. Disponível em: <https://bit.ly/3wvfP5A>. Acesso em: 15 jun. 2018.

. Emenda Constitucional no 95, de 15 de dezembro de 2016. Altera o Ato das Disposiçóes Constitucionais Transitórias, para instituir o Novo Regime Fiscal, e dá outras providências. Diário Oficial da União, Brasília, 15 dez. 2016. Disponível em: <https://bit.ly/3fioAdy>. Acesso em: 21 ago. 2020. 
. Lei no 13.465 , de 11 de julho de 2017. Dispõe sobre a regularização fundiária rural e urbana, sobre a liquidação de créditos concedidos aos assentados da reforma agrária e sobre a regularização fundiária no âmbito da Amazônia Legal; institui mecanismos para aprimorar a eficiência dos procedimentos de alienação de imóveis da União. Diário Oficial da Uniáo, Brasília, 12 jul. 2017. Disponível em: <https://bit.ly/3fdRThg>. Acesso em: 21 ago. 2020.

PAC: 6o balanço - 2015-2018. Brasília: SDI, 2018. Disponível em: <https://bit. ly/3wJ7H1x>. Acesso em: 15 jun. 2018.

. Lei no 13.844 , de 18 de junho de 2019. Estabelece a organização básica dos órgãos da Presidência da República e dos ministérios. Diário Oficial da Uniáo, Brasília, 18 jun. 2019. Disponível em: <https://bit.ly/3yyDAeJ>. Acesso em: 21/08/2020.

CARVALHO, P. Covid-19: mortes se concentram nas áreas pobres de São Paulo. Veja Sáo Paulo, 18 abr. 2020. Disponível em: <https://bit.ly/2QRjQ58>. Acesso em: 25 maio 2020.

CHIARELLI, L. M. A. Habitaçáo social em Pelotas (1987-2010): influência das políticas públicas na promoçấo de conjuntos habitacionais. 2014. Tese (Doutorado) - Instituto de Filosofia e Ciências Humanas, Pontifícia Universidade Católica do Rio Grande do Sul, Porto Alegre, 2014.

COSTA, S. A pandemia expôs o apartheid não oficial do Brasil em toda a sua brutalidade entrevista com Eliane Brum. Instituto Humanitas Unisinos, 29 abr. 2020. Disponível em: $<$ https://bit.ly/3yAVm16>. Acesso em: 30 abr. 2020.

CUNHA, M. M. 60\% dos imóveis de brasileiros estão irregulares, aponta ministério. Associaçáo dos Notários e Registradores do Brasil, maio 2019. Disponível em: <https://bit.ly/3ff5rc7>. Acesso em: 21 ago. 2020.

FIOCRUZ - FUNDAÇÃO OSWALDO CRUZ. Monitora Covid-19. Brasília: Fiocruz, 2020. Disponível em: <https://bigdata-covid19.icict.fiocruz.br/>. Acesso em: 10 ago. 2020.

GOURINCHAS, P. O. Flattening the pandemic and recession curves. In: BALDWIN, R.; DIMAURO, B. W. (Eds.). Mitigating the Covid economic crisis: act fast and do whatever it takes. London: CEPR Press, 2020.

HOLZ, S.; MONTEIRO, T. V. de A. Política de habitacáo social e o direito a moradia no Brasil. In: COLOQUIO INTERNACIONAL DE GEOCRÍTICA: DIEZ AÑOS DE CAMBIOS EN EL MUNDO, EN LA GEOGRAFÍA Y EN LAS CIENCIAS SOCIALES, 1999-2008, 5., 2008, Barcelona. Anales... Barcelona: UB, 2008.

IAMAMOTO, M. V. A questão social no capitalismo. Temporalis, n. 3, 2001.

IBGE - INSTITUTO BRASILEIRO DE GEOGRAFIA E ESTATÍSTICA. Censo demográfico 2010. Rio de Janeiro: IBGE, 2011.

. Estimativas da populaçáo residente no Brasil e Unidades da Federaçáo com data de referência em 1ํㅜ de julho de 2019. Rio de Janeiro: IBGE, 2019.

IPEA - INSTITUTO DE PESQUISA ECONÔMICA APLICADA. Relatório brasileiro para a Habitat III. Brasília: ConCidades; Ipea, 2016. Disponível em: <https://bit.ly/34bDEmP>. Acesso em: 26 ago. 2020.

KRUGER, N. R. M. O plano perfeito: da retórica do direito à moradia a planificação do Programa Minha Casa Minha Vida em Pelotas à negação do habitar. 2018. Dissertação (Mestrado) - Universidade Católica de Pelotas, Pelotas, jun. 2018. 
. Fique em casa? A questão habitacional no Brasil, da retórica sobre o direito à moradia e o Programa Minha Casa Minha Vida até a realidade pandêmica. Porto Alegre: Editora Fi, 2020.

KRUGER, N. R. M. et al. Para uma descolonialidade do pensamento sobre a cidade. In: SEMINÁRIO DE POLÍTICAS SOCIAIS NO MERCOSUL, 7., 2020, Pelotas. Anais... Pelotas: UCPel, 2020. p. 553-564.

LACERDA, N. Movimentos lançam campanha Despejo Zero por proteção à moradia durante a pandemia. Brasil de Fato, jul. 2020. Disponível em: <https://bit.ly/3hWd21j>. Acesso em: 21 ago. 2020.

LANA, R. M. et al. Emergência do novo coronavírus (Sars-CoV-2) e o papel de uma vigilância nacional em saúde oportuna e efetiva. Caderno de Saúde Pública, v. 36, n. 3, p. 1-5, 2020.

MARICATO, E. As ideias fora do lugar e o lugar fora das ideias. In: VAINER, C. A cidade do pensamento único: desmanchando consensos. Petrópolis: Vozes, 2013.

MORAIS, J. L. B. de. As crises do Estado e da Constituiçáo e a transformaçáo espacial dos direitos humanos. Porto Alegre: Livraria do Advogado, 2002.

NABUCO, A.; PRIMI, L.; NABUCO, W. Luta por um teto. Revista Caros Amigos, jul. 2014.

OSÓRIO, L. M. Direito à moradia adequada na América Latina. In: ALFONSIN, B. de M.; FERNADES, E. Direito à moradia e segurança da posse no Estatuto da Cidade: diretrizes, instrumentos e processos de gestáo. Belo Horizonte: Editora Fórum, 2006.

PDHJ - PROVEDORIA DOS DIREITOS HUMANOS E JUSTIÇA. Compilaçáo de instrumentos internacionais de direitos humanos. 1. ed. [s.1.]: UNDP, 2009. Disponível em: <https://bit.ly/2T8YXmA>. Acesso em: 20 abr. 2018.

PENALVA, A. M. S.; DUARTE, S. M. Política habitacional no Brasil: uma nova abordagem para um velho problema. Revista da Faculdade de Direito da Uerj, n. 18, 2010.

PINA, R. Raquel Rolnik: "A captura da política habitacional pela lógica financeira é perversa”. Brasil de Fato, 28 maio 2018. Disponível em: <https://bit.ly/2SsriEg>. Acesso em: 11 jun 2018.

RIBEIRO, L. Metade dos imóveis no país são irregulares, segundo ministério. Correio Braziliense, jul. 2019. Disponível em: <https://bit.ly/3fl8OaB>. Acesso em: 21 ago. 2020.

RODRIGUES, T. A.; SALVADOR, E. As implicaçóes do Programa de Aceleraçáo do Crescimento (PAC) nas políticas sociais. Revista Ser Social, Brasília, v. 13, n. 28, p. 129-156, jan./jun. 2011.

ROLNIK, R. Guerra dos lugares: a colonização da terra e da moradia na era das finanças. São Paulo: Boitempo, 2015.

SILVA, G. A. B. et al. Capacidade do sistema de saúde nos municípios do Rio de Janeiro: infraestrutura para enfrentar a Covid-19. Revista de Administração Pública, v. 54, n. 4, p. 578-594, 2020.

SILVA, L. M. O. Terras devolutas e latifúndio: efeitos da Lei de 1850. Campinas: Editora da Unicamp, 1996.

SILVA, M. O. da S. Política habitacional brasileira: verso e reverso. São Paulo: Cortez, 1989.

SOUZA, M. B. de; HOFF, T. S. R. O governo Temer e a volta do neoliberalismo no Brasil: possíveis consequências na habitação popular. Revista Brasileira de Gestão Urbana, v. 11, 23 set. 2019. Disponível em: <https://bit.ly/34dLPyS>. Acesso em: 21 ago. 2020. 
SROUGI, M. Coronavírus: 'Pobres morrerão nas portas dos hospitais', diz professor da USP. O Globo, 23 mar. 2020. Disponível em: <https://glo.bo/3hSCRil>. Acesso em: 24 ago. 2020.

VAINER, C. A cidade do pensamento único: desmanchando consensos. Petrópolis: Vozes, 2013. 
ENSAIOS EM ECONOMIA AGRÍCOLA E AMBIENTAL 



\section{NÚCLEO DE ESTUDOS DE ECONOMIA AGRÍCOLA (NE²AGRO IPEA-MAPA) ${ }^{1}$}

José Eustáquio Ribeiro Vieira Filho²

\section{INTRODUÇÃO}

O Núcleo de Estudos de Economia Agrícola (NE²AGRO) é um grupo de pesquisa vinculado ao Ipea, mas com o apoio financeiro e o direcionamento das demandas técnicas definidas pelo Mapa. Esse arranjo institucional busca apoiar e subsidiar a tomada de decisão ministerial na formulação e na avaliação de políticas públicas relacionadas ao desenvolvimento do setor agropecuário.

Por meio do termo de execução descentralizada (TED), assinado entre o Ipea e o Mapa em dezembro de 2019, o NE²AGRO foi criado no início de 2020, com a contratação de vários pesquisadores e economistas. $\mathrm{O}$ grupo de pesquisa está diretamente vinculado à Dirur/Ipea e à Secretaria Executiva do Mapa.

\section{FIGURA 1}

Logotipo institucional do $\mathrm{NE}^{2} \mathrm{AGRO}$

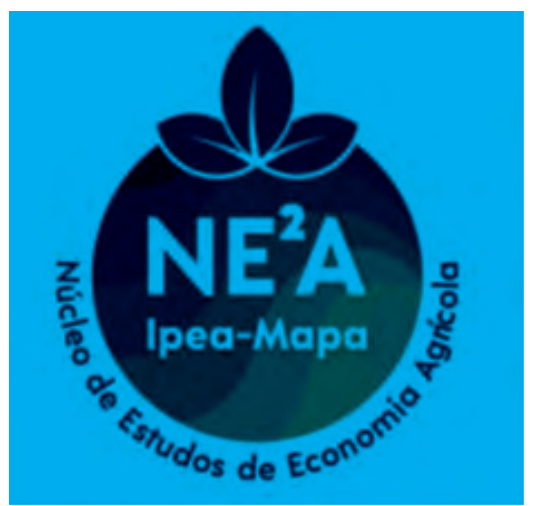

Fonte: Mapa.

1. DOI: http://dx.doi.org/10.38116/brua24art10

2. Técnico de planejamento e pesquisa na Diretoria de Estudos e Políticas Regionais, Urbanas e Ambientais (Dirur) do Ipea; diretor de programa da Secretaria Executiva do Ministério da Agricultura, Pecuária e Abastecimento (Mapa); e professor do Programa de Pós-Graduação em Agronegócio da Universidade de Brasília (Propaga/UnB) e em Economia da Universidade Federal de Viçosa (UFV).E-mail: <jose.vieira@ipea.gov.br>. 
Deve-se ressaltar que o $\mathrm{NE}^{2} \mathrm{AGRO}$ Ipea-Mapa é uma ideia inovadora, que visa construir uma rede de pesquisa baseada em três pilares.

1) Elaboração e execução de políticas produtivas, conduzidas e coordenadas pelo Mapa.

2) Avaliação de impacto de políticas públicas, desenvolvida e monitorada pelo Ipea.

3) Interação com a sociedade científica e com órgãos de pesquisa, tais como as universidades de excelência na área de economia agrícola, as instituiçóes estaduais de pesquisa, bem como o Instituto Brasileiro de Geografia e Estatística (IBGE), entre outros.

\section{OBJETIVO E COOPERAÇÃO DE PESQUISA}

O plano de trabalho estabelece as metas a serem atingidas na criação do grupo de pesquisa, visando realizar açôes de cooperaçáo técnico-científica, intercâmbio de conhecimentos, informaçóes e experiências entre as duas instituiçóes, que assegurem a realização de estudos para o fomento e o desenvolvimento de políticas públicas do setor agropecuário brasileiro.

O Ipea realizou, em dois volumes, um amplo diagnóstico da economia brasileira em 2018. O primeiro volume tratou do crescimento econômico e das várias agendas associadas, tais como o regime fiscal, o mercado de trabalho, a previdência, a reforma tributária, a educação, a saúde, a pesquisa, a matriz energética, a inserção internacional e outros temas (Ipea, 2018a). O segundo volume procurou avaliar a sustentabilidade do crescimento em três dimensôes: i) cooperaçáo federativa e soberania nacional; ii) infraestrutura para o desenvolvimento; e iii) sustentabilidade e competitividade setorial. No segundo volume e na terceira dimensão, foi escrito um breve diagnóstico setorial do agronegócio brasileiro (Ipea, 2018b).

Observou-se que o setor agropecuário foi bastante estudado nos últimos anos. ${ }^{3} \mathrm{O}$ Ipea foi importante na avaliação de políticas, que visou ao desenvolvimento setorial e apresentou os riscos de continuidade da produçấo diante da demanda crescente por alimentos. Em 2018, o IBGE divulgou os resultados preliminares do censo agropecuário de 2017. Uma avaliação mais criteriosa dos dados pode ilustrar, sem dúvida, mudanças relacionadas à estrutura produtiva do setor agropecuário. É fato que um estudo mais aprofundado dos dados sinalizará uma gama enorme de questóes a serem estudadas sobre o setor agropecuário brasileiro. $\mathrm{O}$ acesso aos dados por indivíduos e a elaboração de pesquisas técnicas permitirão uma profunda análise produtiva.

Conforme Ipea (2018b), o instituto havia elaborado soluçôes propositivas ao setor agropecuário, no intuito de reduzir as dificuldades econômicas e estruturais do crescimento econômico. Uma das propostas, relacionada ao agronegócio, era a de se criar, no âmbito do Mapa, da Empresa Brasileira de Pesquisa Agropecuária (Embrapa) ou do próprio Ipea, uma instituiçáo de estudos econômicos do agronegócio que pudesse auxiliar no planejamento estratégico do setor e na elaboração e avaliação de políticas públicas de desenvolvimento pelo governo. A criação do $\mathrm{NE}^{2} \mathrm{AGRO}$ está inserida nessa proposta, que se germinou nos trabalhos institucionais do Ipea.

3. Para trabalhos desenvolvidos no âmbito do Ipea e de instituições parceiras, conferir Gasques, Vieira Filho e Navarro (2010), Gasques et al. (2012), Campos e Navarro (2013), Buainain et al. (2014), Vieira Filho e Gasques (2016), Buainain, Lanna e Navarro (2019), Vieira Filho (2019) e Fishlow e Vieira Filho (2020). 


\section{LINHAS DE PESQUISA}

As linhas temáticas de estudo estão baseadas em sete grandes eixos: i) agricultura familiar e cooperativismo; ii) câmaras setoriais e temáticas; iii) irrigação e diversificação da riqueza; iv) sistema nacional de inovação; v) censo agropecuário (novo diagnóstico); vi) observatório do setor agropecuário; e vii) economia internacional (com a inclusão da temática da economia chinesa nesse contexto). Deve-se ressaltar, contudo, que existem esforços para ampliar as áreas de pesquisa, a fim de que possam incluir novas áreas de interesse, como a questão ambiental e produtiva, bem como a de segurança fundiária e jurídica do sistema produtivo brasileiro.

De forma resumida, as áreas temáticas já criadas se encontram nas subseçôes a seguir.

\subsection{Eixo 1: agricultura familiar e cooperativismo}

As práticas cooperativistas e o fomento do associativismo possibilitam melhores condiçóes de negociação aos pequenos agricultores, aumentando a sua renda e a capacidade de absorção de novas tecnologias. Essa linha buscará a discussão do impacto das falhas de mercado nesse contexto.

\subsection{Eixo 2: câmaras setoriais e temáticas}

Compreende análises sobre instruçôes normativas, processos produtivos, aplicação de defensivos, comercialização e aparato tributário em relação ao adensamento, à sustentabilidade e à competitividade das cadeias de valores, considerando propostas para políticas voltadas para a parceria público-privada.

\subsection{Eixo 3: irrigação e diversificação da riqueza}

A política de irrigação induz a modernização agrícola e a industrialização, com reflexos diretos e indiretos sobre a redução da pobreza no campo e sobre a retenção do êxodo rural. Essa linha buscará explorar as externalidades positivas da irrigação no desenvolvimento socioeconômico.

\subsection{Eixo 4: sistema nacional de inovação}

Buscará propor práticas de gestão inovadoras que forneçam maior flexibilidade e dinamismo gerencial às redes de inovação, explorando o conceito de agilidade, no caso da Embrapa, em seus processos de pesquisa, desenvolvimento e inovaçáo.

\subsection{Eixo 5: censo agropecuário - novo diagnóstico}

Avaliará as diversas políticas entre as últimas contagens censitárias, de modo a propor a manutenção ou a reavaliação dos instrumentos de intervençáo para a melhoria de açôes relacionadas às transformaçôes das atividades agropecuárias, florestais e aquícolas, e também no meio rural.

\subsection{Eixo 6: observatório do setor agropecuário}

Buscará facilitar o acesso a informações mais qualificáveis e georreferenciadas em relação a produção pecuária, irrigação, agricultura familiar e desenvolvimento econômico e ambiental, contribuindo para a prevenção de riscos e aumentando o dinamismo dos processos decisórios do Mapa.

\subsection{Eixo 7: economia internacional}

Essa linha de pesquisa busca subsidiar as decisóes ministeriais nas tratativas negociadoras e em foros internacionais, além de estudar as implicaçóes de movimentos comerciais para 
a competitividade do setor produtivo nacional. Ademais, análises específicas em relação à China serão focadas. Pretende-se auxiliar na formulação de objetivos de médio e longo prazo para a relaçáo do Brasil com a China no setor.

\section{PARCERIA INSTITUCIONAL}

Um bom planejamento de pesquisa é necessário, a ponto de subsidiar as decisões estratégicas do Mapa. É nesse sentido que se definiu a parceria Ipea-Mapa. Essa parceria institucional é uma forma de o Mapa estimular outros órgáos do governo a estudar o setor agropecuário. Uma correta avaliação econômica será importante para subsidiar as decisóes ministeriais. O Mapa fará as transferências dos recursos ao Ipea, que terá como função utilizar sua expertise em pesquisa econômica para montar o grupo de pesquisa, dando todo o apoio institucional ao desenvolvimento das pesquisas.

Existem diversas modalidades de bolsas implementadas, presenciais no Ipea e não presenciais. É importante, na constituição do grupo, manter bolsas não presenciais em instituiçóes acadêmicas e de pesquisas relevantes, como IBGE, UFV, bem como a Escola Superior de Agricultura Luiz de Queiroz da Universidade de São Paulo (Esalq/USP). Busca-se, assim, envolver mais atores dentro do grupo de forma a diversificar os pontos de vista e as análises, no intuito de ampliar a rede de pesquisa.

Objetivamente, caberá ao Mapa:

- efetuar a transferência dos créditos orçamentários e recursos financeiros ao Ipea;

- acompanhar as atividades de execução, avaliando os seus resultados; e

- analisar o relatório de cumprimento do objeto das pesquisas.

Ao Ipea, destinam-se as tarefas a seguir:

- promover a execução e o acompanhamento do objeto das pesquisas na forma e no prazo estabelecidos;

- aplicar os recursos discriminados exclusivamente na consecução do acordo de cooperação;

- permitir e facilitar o acesso a toda a documentação e às informaçóes do projeto ao Mapa; e

- apresentar o relatório final aos interessados dentro do Mapa.

Conjuntamente, as duas instituiçóes devem:

- orientar, supervisionar e cooperar para a implantação das açóes que sáo objeto de cooperação; e

- definir temas de pesquisas a serem estudados que tenham a finalidade de subsidiar a avaliação de políticas públicas relacionadas ao desenvolvimento do setor de economia agrícola.

Como produtos, espera-se a publicação de livros, artigos, textos para discussão, bem como a elaboração de dois relatórios finais, que sejam validados pela Dirur/Ipea e pelo Mapa.

\section{RESULTADOS ESPERADOS}

Além da aproximação do desenvolvimento da pesquisa aplicada, entende-se que essa parceria inovadora aprofundará temas de interesse relacionados ao desenvolvimento do setor agropecuário brasileiro; realizará a avaliação de políticas públicas de fomento produtivo; sistematizará a base de dados de modo a extrair informaçôes relevantes, que possam contribuir 
para a formulação de políticas públicas; e traçará um novo diagnóstico do setor agropecuário brasileiro, conforme os dados do novo censo agropecuário.

\section{EQUIPE DE TRABALHO}

A equipe está constituída em coordenadores técnicos, pesquisadores associados e assistentes de pesquisa e estatística.

- Coordenadores técnicos: José Eustáquio Ribeiro Vieira Filho (Mapa) e Júnia Cristina Peres R. da Conceição (Ipea).

- Pesquisadores associados: Eliseu Roberto de Andrade Alves (Embrapa), José Garcia Gasques (Mapa), Edward Martins Costa (Universidade Federal do Ceará - UFC), José Gustavo Feres (Ipea), Marcelo Dias Paes Ferreira (Universidade Federal de Goiás - UFG), Marcelo José Braga (UFV), Marcus Peixoto (Senado Federal) e Marlon Vinícius Brisola (UnB).

- Assistentes de pesquisa e estatística - Rio de Janeiro: Carlos Andres Charris Vizcaino (UFV e Ipea) e Rayssa Alexandre Costa (Ipea).

- Assistentes de pesquisa - Brasília: Daniela Vasconcelos de Oliveira (Ipea), Érica Basílio Tavares Ramos (UFG e Ipea), Felipe Pinto da Silva (Ipea e Universidade Estadual de Campinas - Unicamp), Maicon Gonçalves Monteiro (Propaga/UnB e Ipea) e Zenaide Rodrigues Ferreira (UnB e Ipea).

- Assistente de pesquisa - São Carlos: Sílvia Ronsom (USP e Ipea).

Mais informaçóes estáo disponíveis na Diretoria de Programa da Secretaria Executiva do Mapa (Esplanada dos Ministérios, bloco D, nono andar, sala 918 - Brasília/Distrito Federal - CEP 70.043-900), no telefone +55 (61) 3218-2598, no e-mail <jose.eustaquio@ agricultura.gov.br> e no site <www.agricultura.gov.br>.

\section{REFERÊNCIAS}

BUAINAIN, A. M. et al. O mundo rural no Brasil do século 21: a formação de um novo padrão agrário e agrícola. Brasília: Embrapa; Editora Unicamp, 2014.

BUAINAIN, A. M.; LANNA, R.; NAVARRO, Z. Agricultural development in Brazil: the rise of a global agro-food power. New York: Routledge, 2019.

CAMPOS, S. K.; NAVARRO, Z. (Org.). A pequena produçáo rural e as tendências do desenvolvimento agrário brasileiro: ganhar tempo é possível? Brasília: CGEE, 2013.

FISHLOW, A; VIEIRA FILHO, J. E. R. Agriculture and industry in Brazil: innovation and competitiveness. New York: Columbia University Press, 2020.

GASQUES, J. G. et al. Total factor productivity in Brazilian agriculture. In: FUGLIE, K. O.; WANG, S. L.; BALL, V. E. (Eds.). Productivity growth in agriculture: an international perspective. Oxfordshire: CAB International, 2012.

GASQUES, J. G.; VIEIRA FILHO, J. E. R.; NAVARRO, Z. (Org.). A agricultura brasileira: desempenho, desafios e perspectivas. Brasília: Ipea, 2010.

IPEA - INSTITUTO DE PESQUISA ECONÔMICA APLICADA. Desafios da naçáo. Brasília: Ipea; MDGP, 2018a. v. 1.

Desafios da naçáo. Brasília: Ipea; MDGP, 2018b. v. 2. 
VIEIRA FILHO, J. E. R. (Org.). Diagnóstico e desafios da agricultura brasileira. Brasília: Ipea, 2019.

VIEIRA FILHO, J. E. R.; GASQUES, J. G. (Org.). Agricultura, transformação produtiva e sustentabilidade. Brasília: Ipea, 2016. 


\section{EXPORTAÇÕES AGROPECUÁRIAS BRASILEIRAS NOS GRANDES MERCADOS ${ }^{1,2}$}

Rogério Edivaldo Freitas 3

\section{INTRODUÇÃO}

Inúmeros estudos mapearam restriçóes estruturais ao contínuo crescimento da economia brasileira (Giambiagi, 2003; Bonelli e Fontes, 2013), sobretudo aquelas relacionadas aos ganhos de produtividade. Atualmente, fatores de conjuntura e novas limitaçôes específicas podem ser acrescidas àquelas limitaçóes. Em paralelo, a agricultura brasileira foi capaz de se transformar de modo a possibilitar que o país se convertesse de um importador líquido para um exportador mundial de alimentos ao longo dos últimos trinta anos. Dessa forma, os bens agropecuários responderam por cerca de $31 \%$ das receitas de exportação brasileiras entre 1989 e 2019. Como é sabido, a capacidade de gerar divisas via exportaçôes é tão importante quanto a capacidade de poupá-las por intermédio da substituição de itens importados por produção local (Bonelli e Malan, 1976). Como efeito paralelo, o setor agropecuário tem suprido parcela crescente da demanda doméstica por alimentos, de modo a contribuir de fato para os saldos comerciais desde 1989. Esses superavit comerciais do setor mostram-se cruciais para a frágil estabilidade macroeconômica brasileira, em particular nos anos de baixo crescimento econômico, por conta da compensação da balança comercial brasileira não agrícola.

Atualmente, o Brasil é uma das principais fontes de exportaçôes mundiais de alimentos, e previsóes de OECD e FAO (2014) sinalizam que a parcela brasileira será crescente nos mercados de açúcar e carnes. Em paralelo, outros analistas (Freitas e Mendonça, 2016) têm mostrado que o país é um dos poucos capazes de expandir sua área de produção agrícola. No âmbito comercial, Estados Unidos, China, Japão e União Europeia têm sido historicamente os maiores mercados importadores de alimentos no cenário global. De acordo com WTO (2019), a União Europeia, por exemplo, respondeu por 38\% das importações globais de alimentos em 2018, com parcelas igualmente representativas de parte de Estados Unidos $(9,5 \%)$, China $(7,9 \%)$ e Japão $(4,5 \%)$.

1. DOI: http://dx.doi.org/10.38116/brua24art11.

2. 0 autor agradece a José Eustáquio R. Vieira Filho pelas correções à versão intermediária do trabalho, eximindo-o das falhas remanescentes.

3. Técnico de planejamento e pesquisa na Diretoria de Estudos e Políticas Regionais, Urbanas e Ambientais (Dirur) do Ipea. 
Adicionalmente, esses parceiros comerciais têm empreendido esforços substantivos para firmar acordos comerciais bilaterais que incluem bens agrícolas (Ferreira e Capitani, 2017). Os Estados Unidos detêm ampla rede de acordos de tal ordem; a Uniáo Europeia focaliza tratados com os países da África e Oriente Médio, ao passo que China e Japão centram suas atençôes em negociações nas cercanias da Ásia e do Pacífico. Acordos bilaterais desse quilate em regra elevam fluxos comerciais de terceiros países que podem substituir a oferta brasileira ao longo do tempo. Destarte, é importante melhor compreender o perfil de demanda daqueles quatro grandes mercados mundiais pelos produtos brasileiros. De um lado, para conhecer tais perfis de demanda no médio e longo prazos e, por outro, de modo a rastrear oportunidades e riscos para o Brasil e prover informaçáo útil às respectivas políticas públicas e privadas em curso.

Nesses termos, o objetivo deste texto é analisar as exportações agropecuárias brasileiras para aqueles quatro grandes parceiros no âmbito das exportaçôes agropecuárias totais entre 1989 e 2019 e identificar os produtos de maior demanda daqueles mercados junto à oferta brasileira no curto prazo recente (2015-2019), além de eventuais dificuldades de acesso. Além da presente introdução, o trabalho apresenta quatro seçôes adicionais. A seção 2 informa o papel de Estados Unidos, China, União Europeia e Japão nas importaçôes agropecuárias mundiais. A seção 3 desenvolve a metodologia do trabalho. E as seções 4 e 5 detalham, respectivamente, os resultados e as conclusóes do trabalho.

\section{ESTADOS UNIDOS, CHINA, UNIÃO EUROPEIA E JAPÃO: PAPEL NAS IMPORTAÇÕES AGROPECUÁRIAS MUNDIAIS}

Diversos fatores afetam a capacidade do Brasil na exportação de produtos agrícolas. Tais fatores incluem as vantagens comparativas nesses bens (Souza et al., 2012; Maranhão e Vieira Filho, 2017; Ferreira e Vieira Filho, 2019), restriçôes na infraestrutura doméstica (Mata e Freitas, 2008), limitantes comerciais externos (Anderson, Mensbrugghe e Martin, 2006) e condicionantes macroeconômicos (Melo, 2002). Outras variáveis como distância aos mercados consumidores finais, posição geográfica dos destinos comerciais e nível de renda dos parceiros de comércio são também enfatizadas em estudos clássicos sobre os fatores determinantes de exportaçōes (Bergstrand, 1985; 1989; Feenstra, Markusen e Rose, 2001).

Nos casos de Estados Unidos, China, União Europeia e Japão, trata-se de grandes mercados em termos agregados e em nível de número de consumidores e potencial de compra. Essas características fazem desses parceiros comerciais mercados agrícolas importantes para os principais exportadores mundiais de alimentos (Santo, Lima e Souza, 2012; WTO, 2018a). Exemplarmente, nos Estados Unidos a economia tem crescido ao ritmo de 2,5\% a.a. desde 1990 (Ipeadata, 2020a), uma taxa expressiva quando observada em longo prazo. De acordo com Santo, Lima e Souza (2012), ainda que o país tenha tido alguma retração econômica após 2008, ele é ainda relevante e sólida fonte de demanda nos mercados mundiais, aí incluídos os de alimentos.

Em termos de produção agropecuária, Luz (2014) enfatiza que os Estados Unidos detêm menos espaço que o Brasil em área agrícola ainda não utilizada. O país é um importador líder nos mercados mundiais agrícolas e também um forte competidor da oferta brasileira, sobretudo em vista de seus amplos e profundos acordos comerciais com terceiros países, além de impor tarifas substantivas sobre produtos lácteos (Santo, 2010). Ao mesmo tempo, os níveis de crescimento recuaram no Japão, em especial após a crise global de 2008 (Ipeadata, 2020b). Não obstante, vários estudos destacam a importância do Japão para as exportaçóes agropecuárias brasileiras. 
Nojosa e Souza (2011), por exemplo, enfatizam as limitaçóes japonesas em termos de área agriculturável e oportunidades para as exportaçóes brasileiras de carnes, preparaçôes de carnes e frutas. ${ }^{4}$ Santo, Lima e Souza (2012) mapearam espaço no mercado nipônico para uma variedade de bens agropecuários graças à elevada dependência do país em importaçôes de alimentos. Neste âmbito, o Brasil não goza tarifas preferenciais de acesso ao mercado do Japão (Nojosa e Souza, 2011), o que por certo limita o acesso de exportaçóes brasileiras àquele destino.

No caso chinês, destaca-se o recente crescimento do produto nacional bruto (PNB) do país em anos recentes, superior à dinâmica de outros mercados relevantes (Austrália, Canadá, Japão, México, Cingapura, e Estados Unidos) no círculo do Pacífico. ${ }^{5}$ Conforme Sanguinet et al. (2017), a China também representa oportunidades singulares para a oferta agropecuária brasileira por conta de sua enorme população e crescente renda per capita. Ademais, conquanto alguns autores (Fukase e Martin, 2016) ponderem que a produção doméstica possa vir a suprir em maior medida a demanda local por alimentos, um nível elevado de importações agropecuárias deve prevalecer em futuro próximo.

Entretanto, há elevadas tarifas chinesas incidentes sobre itens agropecuários, a exemplo dos produtos lácteos (Santo, 2010), tidos como nicho potencial na perspectiva de fortalecimento das relaçôes bilaterais Brasil-China (Miranda, Jank e Soendergaard, 2020), e também barreiras sanitárias e fitossanitárias, que são igualmente significativas em termos de acesso àquele mercado (Mendonça, Carvalho e Reis, 2018). No caso da Uniáo Europeia, em que pese seu baixo dinamismo econômico verificado desde o início do século, representa o principal importador mundial de alimentos (WTO, 2019) e também um comprador líder dos produtos agropecuários brasileiros (Santo, Lima e Souza, 2012). De acordo com Florindo et al. (2014) e Sbarai e Miranda (2014), na União Europeia os mercados de carnes e de preparaçóes de carnes são afetados por regulamentaçóes sanitárias e por medidas náo tarifárias que limitam uma maior entrada dos exportadores brasileiros. Concomitantemente, fatores externos e internos podem reduzir os níveis de suporte europeu aos produtores agropecuários locais, o que poderia se traduzir em novas oportunidades de acesso às exportaçôes brasileiras de carnes, de preparaçóes de carnes e de açúcar (Sá, Marino e Mizumoto, 2012). Todos estes parceiros comerciais são grandes importadores de itens alimentícios. Constituem-se em demandas expressivas por produtos específicos e provavelmente manterão ou reforçarão sua condição de principais demandantes no futuro imediato (Santo, Lima e Souza, 2012; OECD e FAO, 2014; 2016).

\section{METODOLOGIA}

A metodologia do trabalho subdivide-se em duas etapas. A primeira delas diz respeito à estruturação e compatibilização da base de dados, e a etapa seguinte refere-se aos procedimentos de análise. Em termos da estruturação e compatibilização da base de dados, o estudo se baseia em dados de exportaçóes brasileiras do Ministério do Desenvolvimento, Indústria e Comércio Exterior (MDIC), ${ }^{6}$ no período de 1989 a 2019. A definição de produto agropecuário empregada é a presente no Acordo Agrícola e obedeceu a World Trade Organization

4. Mesmo no Nordeste brasileiro tem-se observado uma expansão positiva da produção frutícola, conforme analisado em Souza et al. (2018) e em Sobel e Xavier (2019).

5. Disponível em: <http://databank.worldbank.org/data/home.aspx>.

6. Disponível em: <http://comexstat.mdic.gov.br/pt/home/>. 
(WTO). ${ }^{7}$ Para que se compatibilizassem os itens da Nomenclatura Brasileira de Mercadorias (NBM) (1989-1996) e da Nomenclatura Comum do Mercosul (NCM) (1996-2019), foi requerida uma harmonização das alíneas comerciais brasileiras em acordo com publicação do MDIC. ${ }^{8}$ Assim, os itens do Sistema Harmonizado (SH) de Classificaçáo de Mercadorias correspondentes às exportaçóes agropecuárias são aqueles descritos na tabela 1.

TABELA 1

Códigos SH agropecuários de acordo com WTO (2011)

\begin{tabular}{lc}
\hline Capítulo SH & Item \\
\hline 1 e 2 & Todos \\
4 a 24 & Todos (exceto peixes e suas preparações) \\
29 & 2905.43 e 2905.44 \\
33 & 33.01 \\
35 & 35.01 a 35.05 \\
38 & 3809.10 e 3823.60 \\
41 & 41.01 a 41.03 \\
43 & 43.01 \\
50 & 50.01 a 50.03 \\
51 & 51.01 a 51.03 \\
52 & 52.01 a 52.03 \\
53 & 53.01 a 53.02 \\
\hline
\end{tabular}

Fonte:WTO, disponível em: <http://www.wto.org/english/docs_e/legal_e/14-ag.pdf>.

Elaboração do autor.

Como ferramentas de análise, empreenderam-se os seguintes cálculos/avaliações.

- A participação $\left(P_{i t}\right)$ de cada um dos quatro grandes mercados nas exportaçóes agropecuárias brasileiras no período de 1989 a 2019 (31 anos).

$P_{i t}=\left[X_{i t} / X_{t}\right]$

Em que $X_{i t}$ são exportaçôes agropecuárias Brasil-parceiro $i$ no ano $t$, sendo $i$ China, Estados Unidos, Japão ou União Europeia, $t 1989$, (...) 2019; e $X_{t}$ são exportações agropecuárias brasileiras no ano $t$.

- A participação dos quatro grandes mercados em conjunto nas exportaçóes agropecuárias brasileiras no período de 1989 a 2019.

$P_{4 t}=\left[P_{\text {China } t}+P_{E U A t}+P_{\text {Japãot }}+P_{U E t}\right]$

- Mapeamento dos cinco principais grupos de produtos agropecuários brasileiros importados por cada grande mercado na média de curto prazo recente, assumida para o último quinquênio de dados disponíveis, isto é, para o período 2015 a 2019.

- Identificação dos principais entraves comerciais ao acesso de produtos agropecuários àqueles mercados com base nos respectivos levantamentos da Organização Mundial do Comércio (OMC), a saber: Uniāo Europeia (WTO, 2013a; 2017a), Estados Unidos (WTO, 2016), China (WTO, 2018b) e Japão (WTO, 2013b; 2017b).

7. Disponível em: <http://www.wto.org/english/docs_e/legal_e/14-ag.pdf>.

8. Disponível em: <http://www.desenvolvimento.gov.br/sitio/interna/interna.php?area=5\&menu=1102\&refr=605>. 


\section{ANÁLISE DE RESULTADOS}

Os resultados pertinentes à importância dos quatro grandes mercados nas exportaçôes agropecuárias brasileiras entre 1989 e 2019 estáo ilustrados na tabela 2. A primeira observação refere-se à perda de importância dos mercados de Estados Unidos, Japão e União Europeia no total de divisas auferias pelas exportaçóes agropecuárias brasileiras entre 1989 e 2019 . Ao final da década de 1980, esses três mercados representavam no agregado $72 \%$ das divisas obtidas com as exportaçóes de bens agropecuários pelo Brasil, com ênfase das compras europeias. Ao longo do período avaliado, eles perderam espaço nas exportaçóes agropecuárias brasileiras.

\section{TABELA 2}

Parcela dos grandes mercados nas exportações agropecuárias brasileiras (1989-2019) (Em \%)

\begin{tabular}{|c|c|c|c|c|}
\hline & Japão & China & Estados Unidos & União Europeia \\
\hline 1989 & 5,9 & 1,5 & 13,8 & 52,3 \\
\hline 1990 & 5,5 & 1,7 & 18,8 & 50,3 \\
\hline 1991 & 5,2 & 0,5 & 15,5 & 51,9 \\
\hline 1992 & 5,5 & 0,6 & 14,7 & 52,3 \\
\hline 1993 & 5,1 & 0,2 & 12,7 & 49,7 \\
\hline 1994 & 6,1 & 3,4 & 10,7 & 51,6 \\
\hline 1995 & 6,2 & 5,3 & 8,5 & 45,0 \\
\hline 1996 & 6,1 & 4,6 & 10,2 & 47,2 \\
\hline 1997 & 5,5 & 3,9 & 8,6 & 59,5 \\
\hline 1998 & 5,0 & 3,6 & 8,3 & 58,2 \\
\hline 1999 & 5,2 & 1,6 & 9,6 & 60,1 \\
\hline 2000 & 5,0 & 3,4 & 8,6 & 56,7 \\
\hline 2001 & 4,4 & 4,0 & 5,7 & 58,3 \\
\hline 2002 & 4,5 & 6,1 & 6,6 & 54,6 \\
\hline 2003 & 3,8 & 8,0 & 6,9 & 41,7 \\
\hline 2004 & 4,0 & 8,3 & 6,4 & 38,7 \\
\hline 2005 & 4,5 & 7,5 & 6,1 & 35,6 \\
\hline 2006 & 3,2 & 7,7 & 8,4 & 32,8 \\
\hline 2007 & 3,3 & 8,0 & 6,6 & 36,1 \\
\hline 2008 & 3,7 & 11,5 & 5,7 & 32,5 \\
\hline 2009 & 2,9 & 13,6 & 4,7 & 28,9 \\
\hline 2010 & 3,3 & 14,7 & 4,6 & 25,1 \\
\hline 2011 & 4,0 & 17,9 & 5,5 & 23,8 \\
\hline 2012 & 3,9 & 19,3 & 5,6 & 22,3 \\
\hline 2013 & 3,7 & 23,7 & 5,1 & 20,8 \\
\hline 2014 & 3,1 & 23,4 & 5,1 & 21,1 \\
\hline 2015 & 3,1 & 25,1 & 5,0 & 19,3 \\
\hline 2016 & 3,1 & 25,0 & 5,0 & 18,6 \\
\hline 2017 & 2,9 & 28,5 & 4,6 & 16,5 \\
\hline 2018 & 2,2 & 37,1 & 4,3 & 16,1 \\
\hline 2019 & 3,7 & 33,3 & 4,7 & 16,4 \\
\hline
\end{tabular}

Fonte: MDIC. Disponível em: <http://comexstat.mdic.gov.br/pt/home/>.

Elaboração do autor.

Estados Unidos e União Europeia são os dois maiores exportadores globais de alimentos (WTO, 2019), além de grandes produtores, e possuem políticas agrícolas ativas, seja no âmbito 
interno, seja em sua expressão comercial (WTO, 2013a; 2016; 2017a), o que em parte explica a perda de importância destes parceiros no total das exportaçóes agropecuárias brasileiras.

O Japão, por sua vez, contempla um mercado distante em termos logísticos e com oportunidades ainda não de todo aproveitadas pelo Brasil em termos de exportaçóes agropecuárias. Conforme Nojosa e Souza (2011), barreiras não tarifárias, elevado custo logístico e feroz competição com outros países exportadores (Estados Unidos, Austrália e Canadá) estáo entre os principais desafios dos exportadores brasileiros.

De outra parte, a China expandiu significativamente sua importância nas exportaçôes agropecuárias brasileiras ao longo do período avaliado, partindo de 1,5\% em 1989 para a terça parte das receitas de exportaçóes agropecuárias em 2019. Nessa linha de raciocínio, o mercado chinês tem se colocado como um mercado em expansão e com projeçôes crescentes de demanda por alimentos (Lu, Flegg e Deng, 2011).

O efeito composto do decréscimo participativo de Estados Unidos, Japão e União Europeia e da expansão de parcela devida à China nas exportaçôes agropecuárias brasileiras está apresentado no gráfico 1 . No agregado, os quatro grandes mercados importadores de alimentos representam hoje uma parcela menos expressiva das divisas externas obtidas pela agropecuária brasileira.

Utilizando-se da participação média trienal para o período 1989-2019, é possível observar uma mudança de nível participativo dos quatro grandes mercados. Entre 1989 e 2003, cerca de 72\% das divisas de exportaçóes agropecuárias obtidas pelo Brasil o eram nos mercados de Estados Unidos, União Europeia, China e Japão. Em contraparte, no período 2004-2019, esse patamar situou-se em 53\%, uma redução que provavelmente foi ocupada pela maior penetração em terceiros mercados (Freitas, 2018), sobretudo Oriente Médio, Rússia e outros grandes mercados do Sudeste Asiático.

\section{GRÁFICO 1}

Média móvel trianual de quatro grandes mercados nas exportações agropecuárias (1990-2018) (Em \%)

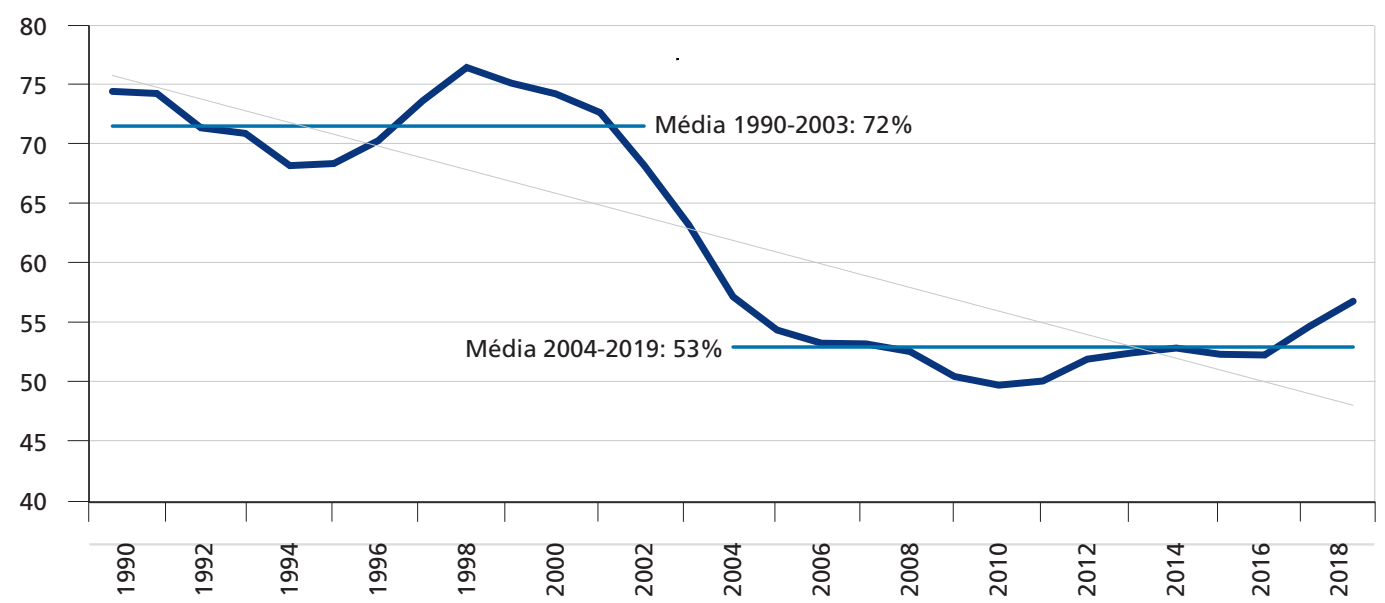

Fonte: MDIC, disponivel em: <http://comexstat.mdic.gov.br/pt/home/>.

Elaboração do autor.

Em nível de importância relativa por grande mercado mundial, a tabela 3 apresenta os principais grupos de produtos importados da agropecuária brasileira, na média participativa do período 2016-2019. Esses cinco grupos de produtos representaram cerca de $86 \%$ das 
aquisições japonesas em valor (US\$) junto à agropecuária brasileira no passado recente, $69 \%$ das aquisições dos Estados Unidos, 98\% das compras chinesas e 75\% das aquisiçóes europeias.

Alguns grupos de produtos merecem destaque, uma vez que são enfatizados em três dos quatro destinos analisados. São eles: sementes e oleaginosos (China, União Europeia e Japão); café e mates (União Europeia, Japão e Estados Unidos); as preparaçóes de hortícolas (União Europeia, Japão e Estados Unidos); e carnes e miudezas (China, União Europeia e Japão). Além disso, cumpre observar que, comparativamente, a pauta chinesa de importaçóes é bastante especializada quanto à demanda de bens agropecuários brasileiros, com forte concentração de aquisiçóes em sementes e oleaginosos. Em termos comparativos, a pauta menos concentrada é a europeia, seguida pelas compras de Estados Unidos e Japão, nesta ordem.

TABELA 3

Participação média dos principais grupos de itens (SH) importados da agropecuária brasileira (2016-2019)

\begin{tabular}{|c|c|c|c|c|}
\hline Grupo & China & $\%$ & União Europeia & $\%$ \\
\hline Líder & Sementes e oleaginosos (12) & 83 & Resíduos de ind. alimentares (23) & 23 \\
\hline $2^{\circ}$ grupo & Carnes e miudezas (02) & 10 & Café e mates (09) & 19 \\
\hline 3 grupo & Açúcares e confeitaria (17) & 2 & Sementes e oleaginosos (12) & 15 \\
\hline $4^{\circ}$ grupo & Algodão (52) & 1 & Preparações de hortícolas (20) & 10 \\
\hline 50 grupo & Tabaco e manufaturados (24) & 1 & Carnes e miudezas (02) & 7 \\
\hline Grupo & Japão & $\%$ & Estados Unidos & \\
\hline Líder & Carnes e miudezas (02) & 35 & Café e mates (09) & 28 \\
\hline 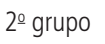 & Cereais (10) & 20 & Bebidas e vinagres (22) & 14 \\
\hline $3^{\circ}$ grupo & Café e mates (09) & 16 & Preparações de hortícolas (20) & 14 \\
\hline $4^{\circ}$ grupo & Sementes e oleaginosos (12) & 9 & Preparações de carne e peixes (16) & 7 \\
\hline 5 grupo & Preparações de hortícolas (20) & 5 & Tabaco e manufaturados (24) & 6 \\
\hline
\end{tabular}

Fonte: MDIC. Disponivel em: <http://comexstat.mdic.gov.br/pt/home/>.

Elaboração do autor.

Quanto às restriçôes de acesso, na União Europeia há diversas políticas de suporte à agricultura (pagamentos diretos, políticas de regulação de estoques e subsídios às exportaçóes) e um amplo leque de barreiras comerciais (tarifas específicas; quotas tarifárias; tarifas preferenciais; proibiçôes ou restriçôes sobre importaçôes; salvaguardas; e sistemas de licenciamento 9 de importaçóes) (WTO, 2017a). O mesmo estudo reporta elevadas tarifas de importação para produtos animais e derivados (19,40\%), lácteos $(35,60 \%)$, cereais e suas preparaçôes (14,90\%), e açúcares e confeitaria (26,80\%). Sob tais amplas limitações de acesso, Vieira e Azevedo (2018) simularam uma área de livre comércio entre Brasil e Uniáo Europeia, obtendo efeitos positivos para a agroindústria brasileira e exportaçóes agropecuárias crescentes àquele mercado.

O Japão, de sua parte, apresenta uma tarifa agropecuária consolidada para o Brasil, que é mais do que quatro vezes a média tarifária geral enfrentada pelo Brasil naquele mercado (WTO, 2013b; 2017b), e detêm uma Estimativa de Suporte ao Produtor ${ }^{10}$ (ESP) elevada

9. Cereais e arroz; açúcar; óleo de oliva e de mesa; leite e produtos lácteos; carnes bovina, suína e de aves; ovos e derivados; alho; e cogumelos em conserva.

10. ESP é o valor monetário anual das transferências de consumidores e contribuintes aos produtores agropecuários, mensurado em nível de porteira, e originário de medidas de políticas de apoio à agropecuária (WTO, 2017b; 2018a). 
(WTO, 2017b). ${ }^{11}$ Ainda assim, é o quarto maior importador de alimentos (WTO, 2018a) e, segundo Santo, Lima e Souza (2012), um mercado potencial para produtos agrícolas brasileiros, sobretudo no contexto de que não há uma área de livre comércio entre Brasil e Japão, de modo que em regra os bens agropecuários brasileiros são tratados sem preferências tarifárias.

No caso do mercado chinês, as tarifas estão consolidadas no formato ad valorem, com média tarifária simples de 15,10\% para os produtos agropecuários e de 8,70\% para os bens náo agropecuários. De acordo com WTO (2018b), a China impóe elevadas tarifas sobre bens de reconhecida competitividade brasileira, como açúcares e confeitaria (30,90\%); cereais e suas preparaçôes (23,30\%); algodão (22\%); e bebidas e tabaco (21,80\%). Além disso, exerce quotas tarifárias em uma série de itens agropecuários (como trigo, milho, arroz, açúcar, lã e algodão) e um sistema de licenciamento de importaçôes incidente sobre produtos de origem animal; produtos vegetais; óleos e gorduras animais e vegetais; e preparaçôes alimentícias. Ademais, como desvantagem adicional para as exportaçôes agropecuárias brasileiras, a China já possui diversos acordos de livre comércio no âmbito Ásia-Pacífico (Canadá, Indonésia, Tailândia, Austrália e Índia). Nesse sentido, Moretto et al. (2017) enfatizaram os efeitos positivos, especialmente para a agropecuária brasileira, de uma simulação de área de tarifa livre entre China e Brasil.

Por fim, em relação aos Estados Unidos, seus níveis de ESP são especialmente elevados para algodão, leite e açúcar refinado (WTO, 2016). De um prisma macro, o país exerce um amplo espectro de suporte aos produtores locais, o que inclui programas por produto, seguro de safra, assistência desastre, créditos garantidos de exportaçáo e apoios específicos para os setores de açúcar e lácteos. Além disso, sua tarifa consolidada junto à $\mathrm{OMC}$ apresenta o valor médio de $9,10 \%$ para produtos agropecuários e de 4,0\% para itens não agropecuários. Tais consideraçóes estão sumarizadas no quadro 1.

QUADRO 1

Principais restrições de acesso a produtos agropecuários por grande mercado

\begin{tabular}{|c|c|}
\hline Japão & Estados Unidos \\
\hline $\begin{array}{l}\text { 1) Tarifa média agrícola cerca de quatro vezes a tarifa média } \\
\text { não agrícola. } \\
\text { 2) Elevada ESP, a mais alta entre os quatro mercados. } \\
\text { 3) ESP destacável para itens como arroz ( } 56 \%) \text {, trigo }(46 \%) \text {, } \\
\text { soja }(42 \%) \text {, lácteos ( } 54 \%) \text { carne bovina }(30 \%) \text {, carne } \\
\text { suína }(61 \%) \text {, carnes de aves ( } 10 \%) \text {, e frutas e vegetais } \\
\text { selecionados }(35 \%) \text {. }\end{array}$ & 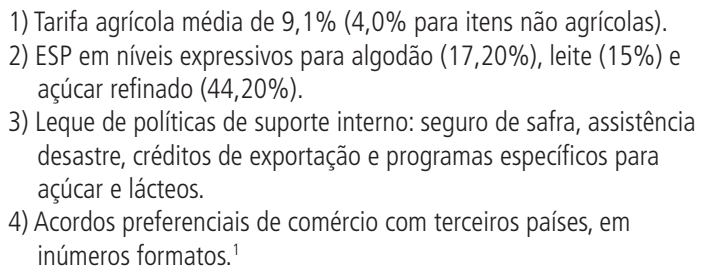 \\
\hline China & União Europeia \\
\hline $\begin{array}{l}\text { 1) Tarifa agrícola média de } 15,1 \% \text { (8,7\% para não agrícolas). } \\
\text { 2) Tarifas elevadas para açúcares e confeitaria (30,90\%); } \\
\text { cereais e preparações }(23,30 \%) \text {; algodão }(22 \%) \text {; e } \\
\text { bebidas e tabaco }(21,80 \%) \text {. } \\
\text { 3) Acordos preferenciais de comércio Ásia-Pacífico. } \\
\text { 4) Quotas e sistemas de licenciamento sobre diversos } \\
\text { itens agropecuários. }\end{array}$ & $\begin{array}{l}\text { 1) Suporte doméstico, tarifas específicas, quotas tarifárias, tarifas } \\
\text { preferenciais, salvaguardas e sistema de licenciamento de } \\
\text { importações. } \\
\text { 2) Tarifas elevadas para produtos animais e derivados }(19,40 \%) \text {; } \\
\text { lácteos }(35,60 \%) \text {; cereais e preparações }(14,90 \%) \text {; e açúcares e } \\
\text { confeitaria }(26,80 \%) \text {. } \\
\text { 3) Ampla incidência de licenciamento de importações para } \\
\text { produtos agropecuários. }\end{array}$ \\
\hline
\end{tabular}

Fonte: WTO(2013a; 2013b; 2016; 2017a; 2017b; 2018b).

Elaboração do autor.

Nota: ${ }^{1}$ Iniciativas mais amplas (Generalized System of Preferences) com a África (African Growth and Opportunity Act) e com o Caribe (Caribbean Basin Initiative).

11. No mercado nipônico, a ESP está concentrada em arroz; trigo; soja; carnes bovina, suína e de aves; e em frutas e vegetais selecionados (WTO, 2017b), todos eles produtos agropecuários correntes ou potenciais para as exportações brasileiras. 


\section{CONSIDERAÇÕES FINAIS}

De modo geral, observa-se uma perda de importância de Estados Unidos, União Europeia e Japão no contexto das receitas de exportaçóes agropecuárias brasileiras - todavia, esses três mercados respondem ainda por cerca de $25 \%$ das divisas de exportaçóes agropecuárias brasileiras. Ao mesmo tempo, a China representa hoje quase um terço das divisas de exportaçóes agropecuárias brasileiras, e tornou-se central nesse contexto.

Em todos os casos, vale observar que esses quatro grandes mercados mundiais importadores de alimentos exercem políticas ativas na construção de acordos bilaterais de comércio, contexto que tende a gerar perdas de espaços para a oferta brasileira ao longo do tempo. Adicionalmente, possuem inúmeras linhas de ação para suporte da produção doméstica e/ou proteção comercial em vários produtos alimentares com maior ou menor nível de adição de valor. Uma contraparte desse processo é a diversificação dos destinos das exportaçóes agropecuárias brasileiras, com o aumento de importância de mercados como Oriente Médio, Rússia e outros países dinâmicos do Sudeste Asiático.

Particularmente quanto ao caso chinês, a elevada concentração de compras em um item específico (sementes e oleaginosas) representa uma vulnerabilidade da posiçáo brasileira. Todavia, pode ser convertida em uma oportunidade, desde que a oferta brasileira possa ser objeto de um processo de agregação de valor e venha a ser tratada em condiçôes de igualdade com as exportaçóes de outros players mundiais. No caso do mercado japonês, as elevadas exigências técnicas e fitossanitárias no que se refere às exportaçôes brasileiras de frutas, vegetais e carnes definem o maior desafio, além da questáo logística associada à distância daquele mercado e da pertinência de negociaçóes bilaterais que tomem estes elementos como centrais.

Dado o tipo de proteçáo comercial e atitude negociadora dos países analisados, acordos comerciais bilaterais brasileiros com esses mercados só terão maior significado desde que contemplem os produtos especificamente apoiados/protegidos do lado importador e aproximem a oferta brasileira presente ou potencial das condiçôes já oferecidas a terceiros países.

\section{REFERÊNCIAS}

ANDERSON, K.; MENSBRUGGHE, D. van der; MARTIN, W. Doha merchandise trade reform: what's at stake for developing countries? Washington: World Bank, 2006. (Policy Researching Working Papers). Disponível em: <https://doi.org/10.1596/1813-9450-3848>.

BERGSTRAND, J. H. The gravity equation in international trade: some microeconomic foundations and empirical evidence. Review of Economics and Statistics, n. 67, v. 3, p. 474-481, 1985. Disponível em: <https://doi.org/10.2307/1925976>.

The generalized gravity equation monopolistic competition, and the factor proportions theory in international trade. Review of Economics and Statistics, n. 71, p.143-153, 1989. Disponível em: <https://doi.org/10.2307/1928061>.

BONELLI, R.; FONTES, J. Desafios brasileiros no longo prazo. Rio de Janeiro: Ibre/FGV, 2013. (Texto para Discussão).

BONELLI, R.; MALAN, P. S. Os limites do possível: notas sobre o balanço de pagamentos e indústria nos anos 70. Pesquisa e Planejamento Econômico, v. 6, n. 2, p. 353-406, ago. 1976.

FEENSTRA, R. C.; MARKUSEN, J. R.; ROSE, A. K. Using the gravity equation to differentiate among alternative theories of trade. The Canadian Journal of Economics, v. 34, n. 2, p. 430-477, 2001. Disponível em: <https://doi.org/10.1111/0008-4085.00082>. 
FERREIRA, B.; CAPITANI, D. H. D. Competitividade do milho brasileiro no mercado internacional. Revista de Política Agrícola, ano XXVI, n. 2, p. 86-99, abr./jun. 2017.

FERREIRA, M. D. P.; VIEIRA FILHO, J. E. R. Inserçáo no mercado internacional e a produçáo de carnes no Brasil. Rio de Janeiro: Ipea, 2019. (Texto para Discussão, n. 2379).

FLORINDO, T. J. et al. Competitividade dos principais países exportadores de carne bovina no período de 2002 a 2013. Revista de Economia e Agronegócio, v. 12, n. 1, 2 e 3, p. 71-90, 2014. Disponível em: <https://doi.org/10.25070/rea.v12i1,2,3.240>.

FREITAS, R. E. Middle East: geographical attraction and net demand for Brazilian agricultural exports. Revista de Economia e Agronegócio, v. 16, n. 3, p. 345-365, 2018.

FREITAS, R. E.; MENDONÇA, M. A. A. Expansão agrícola no Brasil e a participação da soja: 20 anos. Revista de Economia e Sociologia Rural, v. 54, p. 497-516, 2016. Disponível em: <https://doi.org/10.1590/1234-56781806-94790540306>.

FUKASE, E.; MARTIN, W. Who will feed China in the 21st century? income growth and food demand and supply in China. Journal of Agricultural Economics, v. 67, n. 1, p. 3-23, 2016. Disponível em: <https://doi.org/10.1111/1477-9552.12117>.

GIAMBIAGI, F. Restriçốes ao crescimento da economia brasileira: uma visão de longo prazo. Rio Estudos, n. 112, 2003. (Coleção Estudos da Cidade).

IPEADATA. Estados Unidos - PIB - var. real trimestral anualiz. - (\% a.a.) - The Economist ECONMI4_USPIBG34. 2020a.Disponível em: <www.ipeadata.gov.br>.

Japão - PIB - var. real trimestral anualiz. - (\% a.a.) - The Economist - ECONMI4_ JPPIBG34. 2020b. Disponível em: <www.ipeadata.gov.br>.

LU, Z.; FLEGG, A. T.; DENG, X. Regional specialization: a measure method and the trends in China. Munich: MPRA, 2011. (MPRA Paper, n. 33867). Disponível em: <http://mpra. ub.uni-muenchen.de/33867/>. Acesso em: 30 set. 2015.

LUZ. A. O mito da produção agrícola de baixo valor agregado. Revista de Política Agrícola, ano XXIII, n. 2, p. 20-39, abr./jun. 2014.

MARANHÂO, R. L. A.; VIEIRA FILHO, J. E. R. Inserçáo internacional do agronegócio brasileiro. Rio de Janeiro: Ipea, 2017. (Texto para Discussão, n. 2318).

MATA, D. F. G. da; FREITAS, R. E. Produtos agropecuários: para quem exportar? Revista de Economia e Sociologia Rural, v. 46, p. 257-290, 2008. Disponível em: <https://doi.org/10.1590/ s0103-20032008000200001>.

MELO, F. B. H. de. A abertura comercial e o papel dos aumentos de produtividade na agricultura brasileira. São Paulo: Instituto Futuro Brasil, 2002.

MENDONÇA, T. G.; CARVALHO, D. E.; REIS, M. P. O. Efeitos das tarifas, das medidas SPS e TBT e do relacionamento com o BRICS sobre as exportaçôes brasileiras. Revista de Economia e Agronegócio, v. 16, n. 1, p. 67-91, 2018. Disponível em: <https://doi.org/10.25070/rea.v16i1.497>.

MIRANDA, S. H. G.; JANK, M. S.; SOENDERGAARD, N. Opportunities and challenges to strengthen bilateral agri-food trade: the Brazilian perspective. In: JANK, M. S.; GUO, P.; MIRANDA, S. H. G. China-Brazil partnership on agriculture and food security. Piracicaba: Esalq/USP, 2020. 
MORETTO, L. G. et al. Integração comercial entre Brasil e China. Revista de Política Agrícola, ano XXVI, n. 4, p. 7-21, out./dez. 2017.

NOJOSA, G. B. A.; SOUZA, E. T. Japão: crise e oportunidade. Agroanalysis, v. 31, p. 14-15, 2011. OECD - ORGANIZATION FOR ECONOMIC AND CO-OPERATION DEVELOPMENT; FAO - FOOD AND AGRICULTURE ORGANIZATION. OECD-FAO agricultural outlook 2014. Paris: OECD Publishing, 2014. Disponível: <http://dx.doi.org/10.1787/agr_outlook2014-em>. Acesso em: 5 mar. 2016.

OECD-FAO agricultural outlook 2016-2025. Paris: OECD Publishing, 2016. Disponível em: <http://dx.doi.org/10.1787/agr_outlook-2016-en>. Acesso em: 22 fev. 2017.

SÁ, C. D.; MARINO, M. K.; MIZUMOTO, F. M. Redução ou manutenção de subsídios? Agroanalysis, v. 32, n. 1, jan. 2012.

SANGUINET, E. R. et al. Práticas intervencionistas e seus efeitos sobre o comércio internacional de soja: uma análise a partir de um modelo de equilíbrio geral computável e da teoria dos jogos. Revista de Economia e Sociologia Rural, v. 55, n. 4, p. 641-660, out./dez. 2017. Disponível em: <https://doi.org/10.1590/1234-56781806-94790550402>.

SANTO, B. R. do E. Brazil in the world dairy market. Revista de Política Agrícola, ano XIX, n. 1, p. 63-70, jan./mar. 2010.

SANTO, B. R. do E.; LIMA, M. L. F. N. de; SOUZA, C. B. S. de. Os vinte principais mercados para exportação agrícola no futuro. Revista de Política Agrícola, ano XXI, n. 1, jan./mar. 2012.

SBARAI, N.; MIRANDA, S. H. G. Tarifas equivalentes de medidas não tarifárias sobre exportaçóes brasileiras de carne bovina para a UE. Revista de Economia e Sociologia Rural, v. 52, n. 2, abr./jun. 2014. Disponível em: <https://doi.org/10.1590/s0103-20032014000200004>.

SOBEL, T. F.; XAVIER, L. F. Desenvolvimento territorial no Semiárido: uma avaliação a partir da experiência do polo Petrolina-Juazeiro. In: MATA, D.; FREITAS, R. E.; RESENDE, G. M. Avaliaçáo de políticas públicas no Brasil: uma análise do Semiárido. Brasília: Ipea, 2019. v. 1.

SOUZA, H. G. et al. Análise da projeção espacial da fruticultura no nordeste brasileiro. Revista Econômica do Nordeste, v. 49, n. 4, p. 121-141, out./dez. 2018.

SOUZA. R. S. et al. Competividade dos principais produtos agropecuários do Brasil (vantagem comparativa revelada normalizada). Revista de Política Agrícola, ano XXI, n. 2, abr./jun. 2012.

VIEIRA, A. V. S.; AZEVEDO, A, F, Z. Impactos do acordo de livre comércio transatlântico e da integração Brasil União Europeia sobre o Brasil. Revista de Economia e Agronegócio, v. 16, n. 1, p. 42-66, 2018.

WTO - WORLD TRADE ORGANIZATION. Trade policy review: report by the secretariat European Union. Genebra: WTO, 2013a. Disponível em: <https:/www.wto.org/english/ tratop_e/tpr_e/tp384_e.htm>.

Trade policy review: report by the secretariat Japan - trade policies and practices by measure Genebra: WTO, 2013b. Disponível em: <https://www.wto.org/english/tratop_e/ tpr_e/tp376_e.htm>.

. Trade policy review: report by the secretariat - United States. Genebra: WTO, 2016. Disponível em: <https://www.wto.org/english/tratop_e/tpr_e/s350_e.pdf>. 
Trade policy review: report by the secretariat - European Union. Genebra: WTO, 2017a. Disponível em: <https://www.wto.org/english/tratop_e/tpr_e/s357_e.pdf>.

Trade policy review: report by the secretariat - Japan. Genebra: WTO, 2017b. Disponível em: <https://www.wto.org/english/tratop_e/tpr_e/s351_e.pdf>.

World trade statistical review 2018. Genebra: WTO, 2018a. Disponível em: <https:// www.wto.org/english/res_e/statis_e/wts2018_e/wts2018_e.pdf>.

Trade policy review: report by the secretariat - China. Genebra: WTO, 2018b. Disponível em: <https://www.wto.org/english/tratop_e/tpr_e/s375_e.pdf>.

. World trade statistical review 2019. Genebra: WTO, 2019. Disponível em: <https:// www.wto.org/english/res_e/statis_e/wts2019_e/wts2019_e.pdf>. 


\title{
ASSISTÊNCIA TÉCNICA E EXTENSÃO RURAL NO BRASIL: UMA ANÁLISE DO CENSO AGROPECUÁRO DE 2017
}

\author{
Caroline Nascimento Pereira ${ }^{2}$
}

César Nunes de Castro ${ }^{3}$

\section{INTRODUÇÃO}

Durante muitos anos a agricultura foi realizada de forma rudimentar, com baixo uso de inovações tecnológicas. Decorrente em grande parte da vasta extensão territorial, que permitia expandir a produção constantemente, e da contida demanda observada antes da industrialização brasileira, o país alterou um pouco sua base produtiva, e por volta dos anos 1960 parte da população migrava para as cidades, e o campo se tornava um espaço estratégico para fornecimento de alimentos e matérias-primas (Vieira Filho e Fishlow, 2017).

A necessidade de mudanças se fez premente no meio do século XX, e alteraçōes na forma como se produzia começaram, gradativamente, a ser implementadas. A Revoluçáo Verde foi introduzida no Brasil por volta dos anos 1960 e por meio dela incorporaram-se insumos agrícolas, como máquinas, implementos, sementes, defensivos e fertilizantes. Instituíram-se preceitos, os quais incluíam a incorporação da inovação tecnológica e a sua difusão pelo setor e em seus encadeamentos (Buainain, Romeiro e Guanziroli, 2003).

Para atender à inovação tecnológica, instituiçôes de pesquisa agropecuária foram constituídas à época, como a Empresa Brasileira de Pesquisa Agropecuária (Embrapa) e algumas instituiçôes estaduais, além das universidades com áreas de pesquisa voltadas para o tema. Também houve incentivo para formação de pesquisadores especialistas em estudos agropecuários; corolário desse processo, a inovação tecnológica na agropecuária brasileira teve significativo impulso, cujo resultado foi o aumento de produtividade das lavouras e da produção animal e derivados.

A fim de difundir as inovaçóes pelo vasto território brasileiro, surgiu a figura do profissional de Assistência Técnica e Extensão Rural (Ater), com formação acadêmica nas áreas de engenharia agronômica, engenharia agrícola, zootecnia, economia doméstica ou

1. DOI: http://dx.doi.org/10.38116/brua24art12

2. Pesquisadora do Programa de Pesquisa para o Desenvolvimento Nacional (PNPD) na Diretoria de Estudos e Políticas Regionais, Urbanas e Ambientais (Dirur) do Ipea; e doutora em desenvolvimento econômico pela Universidade Estadual de Campinas (Unicamp).

3. Especialista em políticas públicas na Dirur/lpea; e doutorando em geografia pela Universidade de Brasília (UnB). 
engenharia florestal. Comumente referido como extensionista, esse profissional tem como atribuiçâo orientar os agricultores sobre como utilizar as práticas e técnicas mais eficientes na produção agropecuária. Esse novo modelo de desenvolvimento agrícola foi incorporado principalmente pelos produtores rurais do segmento capitalista e, em menor escala, pelos produtores rurais do segmento atualmente conhecido como agricultura familiar (Castro e Pereira, 2017).

Assim, o objetivo deste trabalho é analisar se os produtores agrícolas brasileiros buscam orientação técnica, e quando o fazem, qual a fonte escolhida. Para isso, o trabalho está organizado em duas seçôes, além desta introdução e das conclusóes. Primeiro será apresentado um breve histórico da Ater no Brasil e, em seguida, a análise dos dados do censo agropecuário de 2017, buscando em alguns momentos comparar com o censo agropecuário de 2006 para saber a proporção de estabelecimentos que buscaram orientação técnica e qual a origem desta. Os dados estáo apresentados por região e por tipologia do estabelecimento (agricultor familiar ou agricultor não familiar).

\section{ATER NO BRASIL}

A Ater como um serviço de orientação técnica e disseminação do conhecimento aos produtores agrícolas surgiu nos Estados Unidos e na Europa no final do século XIX e início do século XX. No país norte-americano surgiram primeiramente os farmers' institutes, criados em 1839 e substituídos no século seguinte pelas instituições de Ater, que tinham caráter público, sendo supervisionadas pelo Departamento de Agricultura dos Estados Unidos (United States Department of Agriculture - USDA) (Ros, 2012).

Em meados do século XX, esse modelo começa a ser introduzido em território brasileiro. Em 1948 foi criada em Minas Gerais a primeira instituição a adotar o modelo - a Associação de Crédito e Assistência Rural (Acar) -, com o objetivo de melhorar as condiçóes sociais e econômicas da população do campo. Esta instituição seguiu o modelo norte-americano de difusão de inovações com a atribuição de oferecer assistência técnica e financeira aos produtores rurais para que adotassem as inovaçóes desenvolvidas nos institutos de pesquisa agrícola. Em outras palavras, os institutos de extensão rural tinham como função a interlocução entre os agricultores e as instituiçóes geradoras de inovação para a agropecuária.

As relaçôes estabelecidas pelos extensionistas se materializariam na forma da vinculação dos agricultores aos mercados de financiamento, insumos e comercialização. Após a criação da Acar, surgiram outras instituiçóes nos demais estados do Brasil com o mesmo modelo, oferecendo assistência técnica ao meio rural e elaborando projetos de desenvolvimento agrícola para que os agricultores tivessem acesso ao crédito rural subsidiado pelo Estado.

De acordo com Oliveira (1999), ao final da década de 1950, os serviços de Ater já se encontravam presentes na metade dos estados brasileiros, como em todos das regiôes Sudeste e Sul e expandindo-se para os estados do Nordeste (Ceará, Pernambuco, Bahia, Rio Grande do Norte e Paraíba) e Centro-Oeste (Goiás). A expansão da Acar no território nacional propiciou a institucionalizaçáo efetiva de um serviço de Ater no país, que passou a ser coordenado, em 1956, pela Associação Brasileira de Crédito e Assistência Rural (Abcar), entidade de caráter privado que congregou cada Acar segundo um modelo centralizado e vertical de orientação (Caporal, 1998 apud Oliveira, 1999).

A princípio, essas entidades não estavam sob a responsabilidade do Estado, que passou lentamente a incorporá-las às suas atribuiçôes, oferecendo suporte financeiro, e em troca exigia 
apoio ao projeto de desenvolvimento rural. Como parte deste projeto criou-se a Empresa Brasileira de Assistência Técnica e Extensão Rural (Embrater) em 1975; assim cada Acar passou a se chamar Empresa Estadual de Assistência Técnica e Extensão Rural (Emater), subordinada à Embrater. Esta empresa trabalhava em colaboração com a Embrapa, que produzia e adaptava as inovaçóes tecnológicas, enquanto a Embrater disseminava o conhecimento e a tecnologia para a rede de entidades brasileiras de assistência técnica, as quais, por sua vez, eram responsáveis por difundir as inovações tecnológicas no meio rural brasileiro.

Com a crise fiscal dos anos 1980, a capacidade do Estado ficou altamente reduzida para manter determinados serviços. Com os governos federal e estaduais sem recursos, o serviço de Ater ofertado pelo Estado foi impactado negativamente pelo processo de ajuste fiscal, o que resultou no seu gradativo desmonte e menor capacidade de atuaçáo. Como este serviço é demandado em grande medida pelos pequenos produtores e agricultores familiares, estes foram os mais prejudicados com a extinção da Embrater em 1989.

Paralelamente, outras fontes de orientação técnica cresceram ao longo dos anos, como as próprias empresas integradoras, que vendem insumos tecnológicos e em troca oferecem assistência técnica para utilizar os produtos e aplicá-los nos cultivos. Também houve o crescimento da participação da assistência própria do estabelecimento, em função da grande quantidade e da alta qualidade do ensino agrícola no Brasil, que ao longo dos anos vem capacitando milhares de profissionais para atuar no setor. Com isso, grandes propriedades começaram a contratar seus próprios funcionários para atender às necessidades da lavoura. E, por fim, surgiram as cooperativas, com grande incidência no Sul do Brasil, que possuem profissionais especializados para atender os cooperados.

Desse modo, o modelo de Ater ofertado pelo Estado, apesar de ter sofrido com a diminuição de recursos, foi compensado pelo aumento de outros tipos de orientação técnica, capazes de suprir as necessidades do produtor rural. Assim, a discussão sobre a reestruturação do sistema de assistência técnica pública tem que considerar onde este se faz necessário, levando em conta a localização e a tipologia do estabelecimento, para que se oferte um serviço adequado e atenda às reais necessidades dos produtores rurais.

\section{ATER VIA CENSO AGROPECUÁRIO DE 2017}

Para ilustrar o que foi exposto na seção anterior - a sutil redução do recebimento de orientação técnica pelos estabelecimentos agropecuários brasileiros nos últimos anos, principalmente em relaçáo à assistência técnica de origem governamental -, esta seçáo apresenta dados do censo agropecuário de 2017 sobre o recebimento de orientação técnica e a origem desta. As informaçôes estấo apresentadas por regiôes e por estado, em casos relevantes, além da desagregação por tipologia do estabelecimento - agricultura familiar e não familiar.

Somente $20,2 \%$ dos estabelecimentos do Brasil declararam ter recebido algum tipo de orientação técnica em 2017. Houve uma leve redução em relação a 2006, quando foi de 22,1\%. A região Sul possui a maior proporção de estabelecimentos recebendo algum tipo de orientaçáo técnica $(48,6 \%)$, e é a única regiáo que apresentou crescimento ante o censo de 2006, quando foi de 48,4\%. O Sudeste apresentou 30,7\% em 2006 e 28,6\% de estabelecimentos atendidos em 2017. O Centro-Oeste aparece em terceiro lugar, com 23,7\% de seus estabelecimentos com orientação, porém em 2006 havia 30\% dos casos. A região Norte apresentou 15,5\% de orientaçáo em 2006 e caiu para 10,4\% em 2017. E a regiáo Nordeste aparece em último, com 8,4\% em 2006 e 8,2\% em 2017, a menor proporção de assistência do Brasil. 
O mapa 1 mostra a proporção de estabelecimentos por município que recebeu algum tipo de orientação técnica, segundo o censo agropecuário de 2017. A faixa de cor escura, que representa acima de 50\% dos estabelecimentos com orientação técnica, aparece sobretudo nas regiôes Sudeste e Sul. Municípios de Mato Grosso, Mato Grosso do Sul e Goiás também se destacam.

\section{MAPA 1}

Estabelecimentos agropecuários que receberam orientação técnica - censo agropecuário de 2017

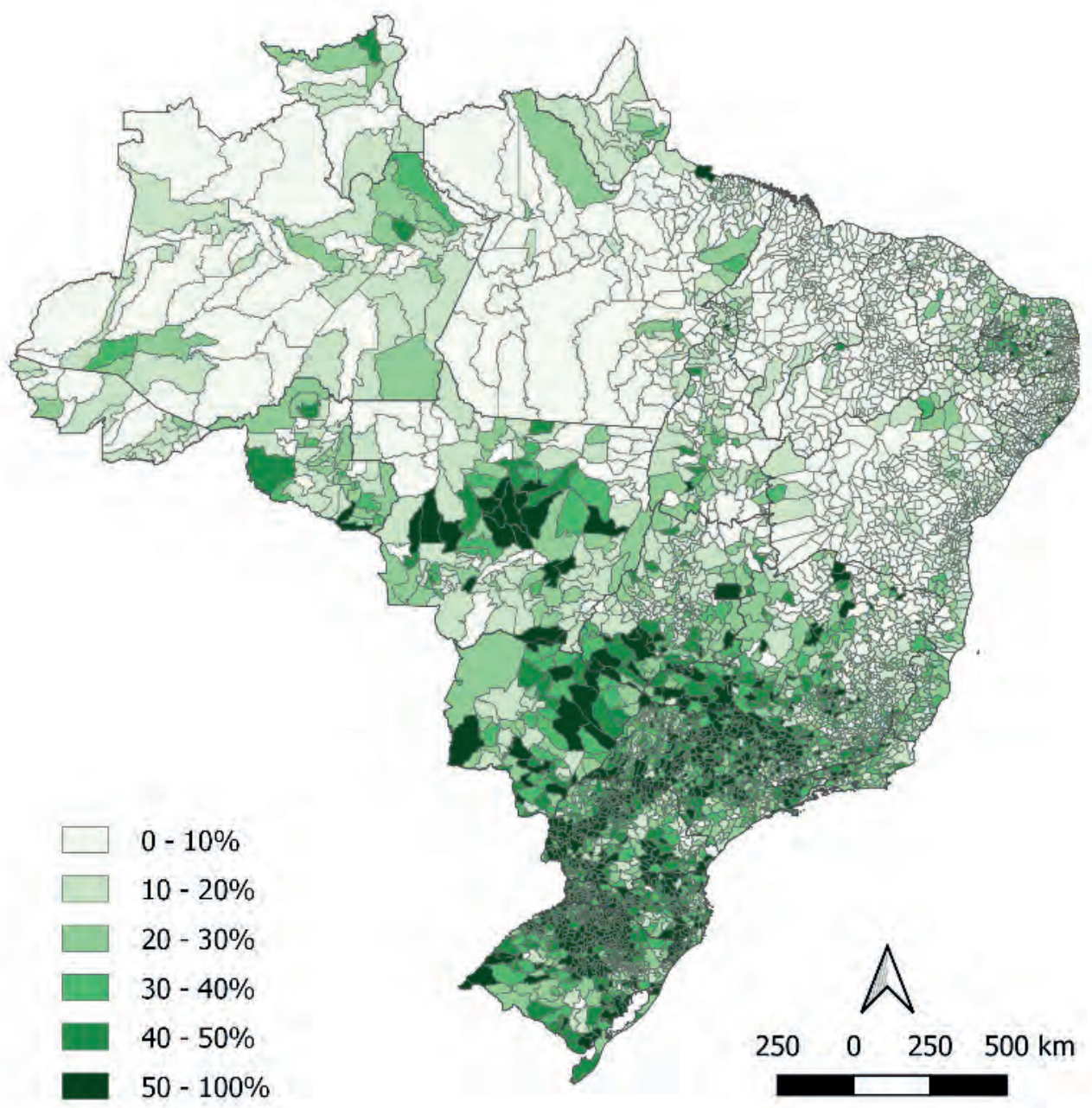

Fonte: IBGE (2019)

Obs.: Figura cujos leiaute e textos não puderam ser padronizados e revisados em virtude das condições técnicas dos originais (nota do Editorial

O conhecimento apenas dos dados gerais de orientação técnica, contudo, é pouco explicativo sobre o que acontece nos estabelecimentos agropecuários. Para tornar esta análise mais substantiva, os dados serão desagregados primeiramente pelo tipo de orientação técnica recebida para comparar os censos agropecuários de 2006 e 2017, e em um segundo momento desagregados pela tipologia do estabelecimento, agricultura familiar e não familiar, para analisar entre esses dois grupos qual origem de orientação técnica é mais recorrente segundo o censo agropecuário de $2017 .{ }^{4}$

4. A desagregação por tipologia de estabelecimento (agricultura familiar e não familiar) não estava disponível para o censo agropecuário de 2006. Deste modo, a comparação entre os dois censos utilizou os dados agregados dos estabelecimentos. 
Pelo tipo de orientação técnica recebida, o censo agropecuário de 2017 apresentou as seguintes fontes: governamental (federal, estadual ou municipal), própria (do próprio produtor), cooperativas, empresas integradoras, empresas privadas, organizaçóes não governamentais (ONGs), Sistema $\mathrm{S}$ e outras. Importante enfatizar que um estabelecimento agropecuário pode receber mais de um tipo de orientação técnica, por exemplo, do governo estadual e de cooperativas.

Da orientação técnica recebida pelos estabelecimentos agropecuários brasileiros em 2017, 37,8\% foram fornecidos pelas instituiçóes de orientação técnica governamental, 30,9\% própria ou de produtores, $24,5 \%$ de cooperativas, $13,2 \%$ de empresas integradoras, entre outras em menor quantidade. Analisando a demanda pelas distintas fontes de orientação técnica entre os censos de 2006 e 2017, nota-se queda em todas as regióes da orientação técnica governamental (tabela 1). A regiáo que apresentou maior redução foi Centro-Oeste, de 36\% para $25 \%$. O Nordeste, apesar da redução, ainda utiliza em grande medida este serviço $60 \%$ entre aqueles que a utilizam. Entre as Unidades Federativas (UFs), houve aumento da orientação pública no Amapá, de $77 \%$ para $87 \%$; Ceará, de $82 \%$ para $85 \%$; Paraíba, de $57 \%$ para $77 \%$; e Distrito Federal, de $86 \%$ para $88 \%$. Todos os demais estados apresentaram redução neste tipo de orientação.

TABELA 1

Origem da orientação técnica recebida pelos estabelecimentos agropecuários - censos agropecuários de 2006 e $2017^{1}$

(Em \%)

\begin{tabular}{|c|c|c|c|c|c|c|c|c|}
\hline & $\begin{array}{l}\text { Governo } \\
(F, E, M)\end{array}$ & $\begin{array}{l}\text { Própria ou } \\
\text { produtor }\end{array}$ & Cooperativas & $\begin{array}{c}\text { Empresas } \\
\text { integradoras }\end{array}$ & $\begin{array}{l}\text { Empresas } \\
\text { privadas }\end{array}$ & ONGs & Sistema S & Outras \\
\hline \multicolumn{9}{|c|}{ Censo agropecuário de 2006} \\
\hline Brasil & 42,9 & 21,9 & 19,7 & 13,4 & 7,4 & 0,6 & - & 2,7 \\
\hline Norte & 72,9 & 18,3 & 6,0 & 1,6 & 2,9 & 0,5 & - & 0,8 \\
\hline Nordeste & 61,9 & 25,7 & 3,6 & 2,6 & 4,2 & 1,8 & - & 2,8 \\
\hline Sudeste & 42,0 & 30,8 & 18,7 & 4,7 & 6,8 & 0,4 & - & 4,1 \\
\hline Sul & 32,3 & 12,5 & 31,1 & 26,5 & 8,4 & 0,3 & - & 2,0 \\
\hline Centro-Oeste & 36,0 & 37,7 & 9,6 & 5,5 & 15,1 & 0,4 & - & 2,5 \\
\hline \multicolumn{9}{|c|}{ Censo agropecuário de 2017} \\
\hline Brasil & 37,8 & 30,9 & 24,5 & 13,2 & 2,8 & 0,8 & 0,7 & 5,1 \\
\hline Norte & 66,7 & 24,3 & 3,7 & 2,7 & 1,4 & 1,3 & 1,2 & 4,5 \\
\hline Nordeste & 60,0 & 23,5 & 7,7 & 2,1 & 1,1 & 3,0 & 1,0 & 6,9 \\
\hline Sudeste & 32,0 & 41,5 & 23,9 & 5,1 & 1,7 & 0,4 & 0,7 & 6,4 \\
\hline Sul & 29,9 & 23,6 & 37,4 & 26,6 & 4,3 & 0,2 & 0,4 & 3,6 \\
\hline Centro-Oeste & 25,0 & 53,2 & 16,1 & 6,0 & 3,7 & 0,3 & 1,8 & 3,9 \\
\hline
\end{tabular}

Fonte: IBGE (2019).

Nota: ${ }^{1}$ Cada estabelecimento agropecuário pode ter recorrido a mais de uma fonte de orientação técnica. Obs.: F - federal; E - estadual; M - municipal.

Em contrapartida, a orientação técnica proveniente de cooperativas, do próprio produtor e de empresas integradoras aumentou em praticamente todas as regiôes. A orientação do próprio produtor cresceu de $22 \%$ para $31 \%$ no Brasil. Subiu sobremaneira na regiáo Sul, de $12,5 \%$ para 23,6\%; no Centro-Oeste, de 38\% para 53\%; e no Sudeste, de 31\% para $41,5 \%$. A única região que apresentou redução neste tipo de orientação foi o Nordeste, de $25,7 \%$ para $23,5 \%$. 
O aumento no uso deste tipo de orientação cresceu substancialmente em muitos estados, como Tocantins, de $23 \%$ para $38 \%$, e Piauí, de $21 \%$ para $30 \%$. No Centro-Oeste houve aumento neste tipo de orientaçáo, exceto para o Distrito Federal, que reduziu de $16 \%$ para $10 \%$.

As cooperativas ganharam maior participação, aumentando de $19,7 \%$ para $24,5 \%$ no Brasil, com decréscimo somente na região Norte, de $6 \%$ para 3,7\%. No Nordeste as cooperativas e as ONGs foram as únicas fontes de orientação que apresentaram aumento de participação para o conjunto da regiáo. Ainda em relação às cooperativas, elas cresceram neste serviço no Matopiba, ${ }^{5}$ em específico no Maranhão, de 1,4\% para 4\%; no Piauí, de 1,7\% para 7\%; e na Bahia, de $4 \%$ para $14 \%$. Também chama a atençáo o crescimento deste tipo de fonte no Distrito Federal, que saltou de 1,5\% para 5,4\%. Em todos os estados da região Sudeste, exceto Rio de Janeiro, as cooperativas estão orientando mais os produtores, bem como na região Sul. Como exemplo, Santa Catarina saiu de 20\% para 33\%. No Centro-Oeste, essa fonte praticamente dobrou de participação em todos os estados.

Com participação menor, porém não menos importante, estão as empresas integradoras, com modesta redução de 13,4\% para 13,2\%. Entre as regióes, cresceu levemente, com exceção do Nordeste, de 2,6\% para 2,1\%. Porém, nesta região, os estados do Matopiba aumentaram a demanda por esta orientaçáo. Tocantins de 0,9\% para 2,5\%; Maranhão de $3,7 \%$ para $4,3 \%$; e Bahia de 3\% para 3,6\%.

A diminuição da participação de cada Emater em grande parte do Brasil é fruto da redução dos investimentos públicos nesta política, em virtude da crise fiscal dos estados. Como mencionado na seção anterior, com o fim da Embrater a situação da assistência técnica pública ficou dependente dos estados, que apresentam variabilidade na oferta deste serviço aos produtores. Ademais, a forma como está estruturada a agricultura em cada região também determina o tipo de orientaçáo recebida. A regiáo Sul é historicamente formada por pequenos produtores cooperados (Farias, 2015), o que explica a maior participação das cooperativas que ofertam orientação técnica.

A região Nordeste responde pela maioria dos agricultores familiares brasileiros, para os quais cada Emater é direcionada (Castro e Pereira, 2017), explicando a participação da assistência técnica pública nesta regiáo. A parcela de orientação própria ou de cooperativas aparece nos espaços mais dinâmicos, como Matopiba, regiáo formada por grandes propriedades voltadas para a produçáo de grãos (Buainain, Garcia e Vieira Filho, 2018).

O Centro-Oeste apresenta a maior participação de orientação própria em função da proeminente produçáo de grâos voltada para o mercado externo. A estrutura de produção é grandiosa, com profissionais especializados dentro da fazenda, prescindindo cada vez mais de orientaçóes externas. Destaca-se a exceção do Distrito Federal, que apresentou alta participação da Emater como fonte de orientação técnica. Isto possivelmente se deve entre outros motivos ao bom trabalho da empresa, que já havia sido certificada em 2015 pelo Ministério do Desenvolvimento Agrário (MDA) pelas boas práticas agrícolas (Castro e Pereira, 2017).

Analisando apenas os agricultores familiares, observa-se o menor acesso à orientaçáo técnica entre estes - $18 \%$ para o conjunto brasileiro desses agricultores. No Centro-Oeste apenas $16,4 \%$ do total de agricultores familiares recorreu a algum tipo de orientação.

5. Região formada pelos estados do Maranhão, Tocantins, Piauí e Bahia. 
Nas demais regiôes também há menor uso de orientação técnica por esse tipo de agricultor, $8,8 \%$ nos estabelecimentos do Norte; $7,3 \%$ no Nordeste; e $24,5 \%$ no Sudeste. A exceção se encontra na regiáo Sul, com maior uso de orientação técnica entre os agricultores familiares $(48,9 \%)$ do que em relação ao todo. Entre os estabelecimentos da agricultura não familiar, $27 \%$ recorreram a algum tipo de orientação técnica no censo agropecuário de 2017 , ou seja, há maior informação técnica neste tipo de estabelecimento.

Assim, entre aqueles estabelecimentos agropecuários que receberam algum tipo de orientação técnica, há distinções entre os de agricultura familiar e os de agricultura não familiar. Entre os primeiros, que receberam orientação técnica, $18,2 \%$ do total, a governamental foi preponderante (43\%), seguida de cooperativas (26\%). Já entre os estabelecimentos de agricultura não familiar que receberam orientação técnica, a preponderância foi por orientação própria ou do próprio produtor $(51,3 \%)$. Na região Nordeste, a participação governamental é ainda mais significativa, $66,8 \%$ entre estabelecimentos de agricultura familiar que receberam orientação, e também nos de agricultura não familiar, com $43,6 \%$, porém aqui a orientação própria ou do próprio produtor também apresentou forte participação, 42,5\% (tabela 2).

TABELA 2

Origem da orientação técnica recebida segundo tipologia do estabelecimento - agricultura familiar ou não familiar (2017)

(Em \%)

\begin{tabular}{|c|c|c|c|c|c|c|c|c|}
\hline & $\begin{array}{l}\text { Governo } \\
(F, E, M)\end{array}$ & $\begin{array}{l}\text { Própria ou do } \\
\text { próprio produtor }\end{array}$ & Cooperativas & $\begin{array}{c}\text { Empresas } \\
\text { integradoras }\end{array}$ & $\begin{array}{c}\text { Empresas } \\
\text { privadas }\end{array}$ & ONGS & Sistema S & Outras \\
\hline \multicolumn{9}{|c|}{ Agricultura familiar - não } \\
\hline Brasil & 25,5 & 51,3 & 21,8 & 6,9 & 3,1 & 0,6 & 0,8 & 4,8 \\
\hline Norte & 44,3 & 48,0 & 3,1 & 3,1 & 2,3 & 0,6 & 1,1 & 4,8 \\
\hline Nordeste & 43,6 & 42,5 & 5,5 & 2,6 & 1,5 & 2,2 & 1,1 & 6,6 \\
\hline Sudeste & 21,3 & 56,9 & 23,1 & 5,1 & 2,0 & 0,3 & 0,6 & 5,5 \\
\hline Sul & 21,9 & 41,9 & 38,1 & 12,8 & 4,9 & 0,2 & 0,5 & 3,4 \\
\hline Centro-Oeste & 13,0 & 68,6 & 14,1 & 6,3 & 4,2 & 0,2 & 1,2 & 3,8 \\
\hline \multicolumn{9}{|c|}{ Agricultura familiar - sim } \\
\hline Brasil & 43,4 & 21,7 & 25,7 & 16,0 & 2,6 & 0,9 & 0,7 & 5,2 \\
\hline Norte & 76,1 & 14,2 & 3,9 & 2,5 & 1,0 & 1,6 & 1,2 & 4,4 \\
\hline Nordeste & 66,8 & 15,6 & 8,5 & 1,9 & 0,9 & 3,4 & 1,0 & 7,0 \\
\hline Sudeste & 38,9 & 31,6 & 24,4 & 5,2 & 1,5 & 0,4 & 0,7 & 7,1 \\
\hline Sul & 32,1 & 18,6 & 37,2 & 30,4 & 4,1 & 0,2 & 0,4 & 3,7 \\
\hline Centro-Oeste & 39,8 & 34,0 & 18,6 & 5,5 & 3,1 & 0,4 & 2,5 & 4,1 \\
\hline
\end{tabular}

Fonte: IBGE (2019).

Obs.: F - federal; E - estadual; M - municipal.

O destaque é a diferença desta distribuição entre as regiôes pelo tipo de orientação recebida. As regióes Norte e Nordeste têm semelhanças quanto à origem da orientação recebida e à tipologia do estabelecimento. Para os estabelecimentos de agricultura náo familiar que receberam orientação técnica, a preponderância é de orientação própria e governamental no Norte e Nordeste, cerca de $45 \%$ para ambas as fontes. Entretanto, para as UFs de maior dinamismo agrícola na regiáo Norte, como Tocantins e Pará, que possuem muitos estabelecimentos pecuários e também com produção de soja, entre outros grãos, a orientação técnica própria, típica de grandes propriedades, é predominante, 59,4\% e 57,2\%, respectivamente. Ainda nos estabelecimentos de agricultura não familiar que receberam orientação, também ocorre 
a maior participação de orientação própria nos estados de Pernambuco, 46,4\%; Rio Grande do Norte, 48,9\%; Piauí, 48,8\%; Maranhão, 56,8\%; e Bahia, 51,5\%.

Entre os poucos estabelecimentos de agricultura familiar que recorreram a algum tipo de orientação técnica, 76\% utilizam orientação governamental no Norte e $67 \%$ dos nordestinos. Entre os que receberam orientaçáo, a orientaçáo própria aparece em 14\% dos estabelecimentos do Norte e 15,6\% do Nordeste. Esses valores são os maiores para a orientaçáo governamental entre todas as cinco regiôes brasileiras, ou seja, os estabelecimentos familiares do Norte e Nordeste são os que mais utilizam, em termos relativos, a orientação técnica oriunda do governo.

Na região Sudeste, para os estabelecimentos de agricultura não familiar que receberam orientação, observa-se a predominância de orientação própria $(56,9 \%)$, seguida de cooperativas $(23,1 \%)$. O Espírito Santo apresenta a menor proporção de orientação técnica própria da regiấo $(46,1 \%)$, seguida de orientação governamental $(28,6 \%)$ e cooperativas $(22,2 \%)$. Por sua vez, a orientação própria se destaca no Rio de Janeiro (60\%), onde também há maior orientação governamental da região (34,3\%). Em São Paulo, quase 60\% da orientação técnica é de origem própria, seguida de cooperativas (27\%), enquanto a assistência pública foi mencionada em $12,8 \%$ dos estabelecimentos.

Entre os estabelecimentos de agricultura familiar que receberam orientação técnica, a governamental é predominante no Sudeste $(38,9 \%)$, não obstante a orientação própria ocorrer em número considerável de estabelecimentos (31,6\%). Em São Paulo, mesmo entre as propriedades de agricultura familiar, a orientação técnica própria é de maior ocorrência (36\%). A orientação governamental é predominante nos demais estados (Minas Gerais, 41\%; Espírito Santo, 38,3\%; Rio de Janeiro, 48\%). As cooperativas são fonte importante de orientação nas propriedades do Espírito Santo (32\%). No geral, há relativo equilíbrio entre a orientação pública, própria e de cooperativas nos estabelecimentos da agricultura familiar do Sudeste.

A regiáo Sul se destaca pela significativa participação do cooperativismo na orientação técnica, tanto nas propriedades familiares como nas não familiares que receberam orientação técnica, sendo $37 \%$ e $38 \%$, respectivamente. Nestas últimas, a orientação própria é predominante (41,9\%), e a governamental aparece em terceiro lugar, com $21,9 \%$. Porém, entre as UFs, o Paraná possui maior participação de cooperativas na orientação técnica dos produtores não familiares $(51,2 \%)$ e a orientação própria vem em seguida (37\%). No Rio Grande do Sul há o predomínio da orientação técnica própria (50\%), seguida das cooperativas (29\%). E Santa Catarina surge como o estado sulista em que as propriedades não familiares fazem mais uso da assistência pública $(38 \%)$.

Entre as propriedades familiares da região Sul que receberam orientação, a governamental aparece em segundo lugar (32\%). Interessante que os estabelecimentos de agricultura familiar no Paraná recorrem em maior medida às cooperativas (44\%) do que à orientação pública (24,5\%). No Rio Grande do Sul a orientaçáo pública predomina (35\%) e as cooperativas também (34\%). Em Santa Catarina a situação é parecida com o Rio Grande do Sul, predomínio similar entre orientação governamental e cooperativas - 37\% e 34\%.

O Centro-Oeste apresenta comportamento distinto, em que a orientação própria é predominante nos estabelecimentos de agricultura não familiar que receberam orientação $(68,6 \%)$, seguida de cooperativas (14\%) e a menor participação de todas as regióes brasileiras na orientação governamental (13\%). Em Mato Grosso, Mato Grosso do Sul e Goiás a 
orientação própria é cerca de $70 \%$; enquanto no Distrito Federal ela foi apontada como fonte de informaçôes em apenas $18 \%$ dos estabelecimentos não familiares que receberam orientação. As cooperativas aparecem em maior medida em Goiás (20\%) e Mato Grosso do Sul (15\%). A orientação governamental surge em cerca de 10\% dos estabelecimentos de Mato Grosso, Mato Grosso do Sul e Goiás e em $80 \%$ dos estabelecimentos não familiares do Distrito Federal que receberam alguma orientação.

Entre os agricultores familiares do Centro-Oeste que recorreram à orientação, houve maior uso da governamental (40\%) e da própria (34\%). Em Goiás, os agricultores familiares com orientação se valem em maior medida da orientação própria (42\%), governamental (26\%) e cooperativas (25\%). Em Mato Grosso do Sul observa-se maior ocorrência da orientação pública $(53 \%)$ e própria (24\%) entre aqueles com alguma orientação. Em Mato Grosso também se observa maior orientação própria mesmo entre os agricultores familiares (38\%), seguida da orientação governamental (36\%). A maior contribuição da assistência pública de todas as UFs brasileiras se encontra no Distrito Federal - 96\% dos estabelecimentos familiares que afirmaram utilizar algum tipo de orientação recorreram à Emater do Distrito Federal para obter orientação.

\section{CONSIDERAÇÕES FINAIS}

A redução na orientação técnica recebida pelos estabelecimentos agrícolas brasileiros entre os dois censos foi sutil, de 22,1\% para 20,2\%. Essa redução pode ser atribuída em maior medida à diminuição da participação das empresas públicas de assistência técnica em todas as regiôes, porém com crescimento em nível estadual para Amapá, Ceará, Distrito Federal e Paraíba. Em contrapartida, aumentou o recebimento de orientação proveniente do próprio produtor e de cooperativas, principalmente nos espaços que contam com agricultura mais dinâmica, como Centro-Oeste, Sul e Matopiba.

Ao desagregar entre os estabelecimentos de agricultura familiar e não familiar, observa-se que o segundo grupo demanda mais este tipo de serviço (27\%), ante $18 \%$ dos estabelecimentos familiares. Entre as regióes, há muita disparidade, fruto da intensidade e do tipo das atividades agrícolas em cada região, bem como da estrutura do serviço de Ater em cada UF. O histórico de associativismo também influenciou os resultados. Na região Sul, as cooperativas têm grande presença na orientação técnica dos produtores. A região Centro-Oeste chama a atenção para o predomínio da orientação técnica própria, em virtude das grandes propriedades que contam com profissionais especializados. A exceção se encontra no Distrito Federal, onde há maior participação da assistência pública aos produtores. Norte e Nordeste são as áreas mais dependentes da orientação técnica de Emater, pois é onde se encontra a maioria dos estabelecimentos familiares.

Os dados dos censos agropecuários de 2006 e 2017, analisados neste artigo, indicam a considerável importância da Ater pública em todas as regióes (mesmo naquelas em que não é predominante), principalmente entre os estabelecimentos da agricultura familiar. Esta importância justifica a maior discussão sobre este serviço e, possivelmente, a sua ampliação. Este artigo não focou no debate acerca da necessidade de ampliação do serviço de Ater, o qual será objeto de estudo em trabalhos futuros, procurando relacionar os dados aqui apresentados com possíveis explicações sobre a menor oferta de Ater pelas UFs brasileiras e o crescimento da participação das outras fontes como cooperativas e orientação própria.

Além da questão da Ater pública, a sua qualidade em todas as fontes é importante com relação à eficiência produtiva (técnica, econômico-financeira, ambiental etc.) dos 
estabelecimentos agropecuários brasileiros. Os dados do censo agropecuário de 2017 não permitem fazer inferências sobre essa questão, e sugere-se ao Instituto Brasileiro de Geografia e Estatística (IBGE) que avalie a viabilidade de inclusão de perguntas nesse sentido em futuras iteraçôes da avaliação censitária agropecuária.

\section{REFERÊNCIAS}

BUAINAIN, A. M.; GARCIA, J. R.; VIEIRA FILHO, J. E. R. A economia agropecuária do Matopiba. Revista Estudos Sociedade e Agricultura, v. 26, n. 2, jun./set. 2018.

BUAINAIN, A. M.; ROMEIRO, A. R.; GUANZIROLI, C. Agricultura familiar e o novo mundo rural. Sociologias, Porto Alegre, ano 5, n. 10, p. 312-347, jul./dez. 2003.

CASTRO, C. N.; PEREIRA, C. N. Agricultura familiar, assistência técnica e extensão rural e a política nacional de Ater. Brasília: Ipea, out. 2017. (Texto para Discussão, n. 2343).

FARIAS, F. R. A dinâmica geoeconômica do cooperativismo agropecuário do Sul do Brasil. 2015. Tese (Doutorado) - Centro de Filosofia e Ciências Humanas, Universidade Federal de Santa Catarina, Florianópolis, 2015.

IBGE - INSTITUTO BRASILEIRO DE GEOGRAFIA E ESTATÍSTICA. Censo agropecuário 2017. Rio de Janeiro, 2019. Disponível em: <https://sidra.ibge.gov.br/pesquisa/censo-agropecuario/ censo-agropecuario-2017>. Acesso em: 15 jul. 2020.

OLIVEIRA, M. M. As circunstâncias da criação da extensão rural no Brasil. Cadernos de Ciência e Tecnologia, Brasília, v. 16, n. 2, p. 97-134, 1999.

ROS, C. A. Gênese, desenvolvimento, crise e reformas nos serviços públicos de extensão rural durante a década de 1990. Mundo Agrário, La Plata, v. 13, n. 25, 2012.

VIEIRA FILHO, J. E. R.; FISHLOW, A. Agricultura e indústria no Brasil: inovação e competitividade. Brasília: Ipea, 2017. 305 p. 


\section{A COMUNICAÇÃO CORPORATIVA E AS POLÍTICAS DE COMBATE ÀS MUDANÇAS CLIMÁTICAS: TEORIAS, PERSPECTIVAS E UMA AVALIAÇÃO DO USO DAS REDES SOCIAIS NO CASO DO BRASIL ${ }^{1}$}

Maria Bernadete Sarmiento Gutierrez²

\section{INTRODUÇÃO}

As mudanças climáticas já estáo produzindo efeitos visíveis e mensuráveis que se fazem sentir por meio da elevaçáo do nível do mar e seus impactos sobre as regióes costeiras, do desequilíbrio climático, das precipitaçôes e secas extremas, das colheitas com padróes incertos, entre outras consequências. Os efeitos negativos não só afetam a esfera econômica como se fazem sentir no plano geopolítico, provocando migraçôes forçadas com consequências políticas, sociais e econômicas.

Sem uma coordenaçáo internacional, em que todos os países se engajem numa ação de combate vigorosa, as mudanças climáticas colocam em risco o futuro das geraçóes futuras. As previsões sobre o status quo, isto é, sem uma reversão nas tendências nas emissôes dos principais gases do efeito estufa (GEE), principalmente dióxido de carbono e metano, são bastante pessimistas. Considerando que existe uma enorme desigualdade nas emissóes de GEE, em que países desenvolvidos são responsáveis pela principal parcela desses gases numa perspectiva passada e presente, o próprio processo de desenvolvimento dos países em desenvolvimento introduz pressōes adicionais sobre as emissōes futuras.

As repostas ao enfrentamento das mudanças climáticas são de dois tipos: a descarbonização e a adaptação. Ambos demandam mudanças estruturais nas sociedades com a participação de todos agentes em seus âmbitos respectivos - governos, empresas, consumidores, entidades da sociedade civil. Adentrar-se na discussão das responsabilidades relativas de cada agente foge do escopo deste trabalho, mas importa ressaltar a responsabilidade social das empresas (RSE) em açôes mitigadoras nas emissóes de GEE não só pela sua grande participação na questão como também pelo fato de que os acordos climáticos ainda náo alcançaram um status legal de cumprimento.

1. DOI: http://dx.doi.org/10.38116/brua24art13

2. Técnica de planejamento e pesquisa na Diretoria de Estudos e Políticas Regionais, Urbanas e Ambientais (Dirur) do Ipea. 
As empresas podem e devem participar do esforço de mitigação nas emissóes de GEE - elas têm ainda grande participação nas emissões dos gases causadores do efeito estufa e também podem fazer escolhas tecnológicas importantes. Por exemplo, um estudo da organização norte-americana de pesquisas Climate Accountability Institute chega ao resultado de que um grupo de vinte companhias é responsável por mais de um terço das emissóes de GEE em todo o mundo desde 1965. A análise abarca o período iniciado em 1965 até 2017. De acordo com a análise, vinte companhias produtoras de petróleo, gás natural e carvão foram responsáveis por 480,16 bilhóes de toneladas de GEE liberados na atmosfera nesse período. Esse montante representa 35\% das emissóes totais de combustíveis fósseis e cimento.

No combate ao aquecimento global, importa destacar o papel relevante da comunicação para mobilizar o engajamento necessário para uma efetiva priorização das açôes e políticas apropriadas, com a disseminação de informação para promover mudanças de atitudes/comportamentos dos cidadãos, tendo como objetivo final reduzir as emissóes de GEE. Os novos meios de comunicação, permitidos pelo amplo uso da internet, amplificam esses efeitos e, potencialmente, poderiam contribuir para disseminar a informação sobre o problema social dado pelo efeito estufa como uma questão global, promovendo um engajamento dos diferentes agentes, com possíveis impactos positivos. ${ }^{3}$

No contexto amplo delineado anteriormente, o objetivo deste trabalho é mostrar como as empresas têm utilizado formas diferentes de comunicação para disseminar informações sobre as açóes no combate ao aquecimento global no Brasil. Para a consecução deste objetivo, na seção 2, uma breve exposição dos principais marcos de comunicação, de acordo com Evans et al. (2018), é feita. Na seçâo 3, discute-se a relação entre comunicaçáo corporativa, sustentabilidade e mídias sociais, também sendo apresentados alguns resultados de estudos internacionais, apontando no sentido do uso crescente das mídias sociais para comunicar açôes ambientais. Na seção 4, faz-se um breve panorama das açóes das empresas brasileiras direcionadas ao combate do aquecimento global. Na seção 5, mostra-se como o setor corporativo brasileiro tem comunicado suas açôes de sustentabilidade, emergindo o resultado de sua baixa utilização das mídias sociais para disseminar informaçóes de cunho ambiental. Finalmente, na seção 6 , conclusóes preliminares são apresentadas, assim como propostas de melhorar este estudo e possíveis linhas futuras de pesquisa.

\section{MARCOS DE COMUNICAÇÃO DAS MUDANÇAS CLIMÁTICAS: ALGUNS ASPECTOS TEÓRICOS E INSTITUCIONAIS}

Os meios de comunicação têm papel central na provisão de informação, influenciando as percepções e a consciência dos cidadãos, com impactos em ações e políticas (públicas e corporativas), no comportamento dos cidadãos e nas demandas sociais em relação às mudanças climáticas. Carvalho (2010) aponta a necessidade de ampliar o alcance da comunicaçáo de forma a incluir grupos diversos em todos os níveis da sociedade, uma vez que essa discussão tem sido feita de forma extremamente concentrada em um pequeno universo elitista de

3. Este texto não cobre todas as formas de comunicação corporativa quanto à mudança global do clima, mas sim o potencial uso das redes sociais com o fim de disseminar informações relevantes no campo climático, seguindo a linha de Reilly e Hyan (2014). Para enfatizar essa delimitação, o governo federal, por exemplo, se organiza para manter uma plataforma de relato voluntário de emissões corporativas (Decreto № 9.172/2017). Empresas também podem comunicar dados de emissões de GEE em relatórios próprios de responsabilidade socioambiental ou, ainda, em relatórios padronizados, elaborados e/ou verificados por terceiros para atender a normas internacionais, pré-requisito para acessar determinados mercados, entre outros. Poderia ser o caso de que as comunicações fossem mandatórias, como em São Paulo, onde empresas que emitem mais que determinada quantidade de GEE anualmente precisam comunicar suas emissões. 
governos, instituições internacionais, grandes empresas etc. A autora também destaca que os fóruns para o debate de políticas combatendo o aquecimento global, sejam nacionais ou internacionais, têm como espelho uma mídia muito focada nesse mundo pequeno, excluindo a maior parte dos diferentes agentes. Trata-se de uma mídia que cobre os eventos de reunióes e assembleias intergovernamentais, compatível com a visão de que o plano internacional é o nível adequado para as açóes de mitigaçáo do aquecimento global. Entretanto, como a autora enfatiza, a arena global não é o espaço adequado para levar a açóes coletivas de outros agentes. De acordo com Carvalho (2010), não se deve reservar aos chefes de Estado a discussão da política de aquecimento global, pois provavelmente não levará a resultados promissores em termos de seu combate efetivo.

No plano internacional, o principal fórum de negociaçóes para açóes de combate ao aquecimento global ocorre no âmbito da Convenção-Quadro das Naçóes Unidas sobre a Mudança do Clima (CQNUMC). Desde a Rio-92, a comunidade internacional tenta chegar a uma solução que freie as emissóes de GEE, a fim de pelo menos estabilizar a concentração desses gases na atmosfera. São negociações difíceis, que exigem unanimidade, e permeadas pelas enormes disparidades de objetivos dos diferentes países ${ }^{4}-$ destaca-se aqui o Protocolo de Quioto, uma etapa simbólica nas negociaçôes, mas que produziu efeitos muito modestos. ${ }^{5}$ Além disso, as grandes expectativas com relação à Cúpula de Copenhague de 2009, para maiores compromissos dos países nas metas de redução, ficaram longe de ser realizadas, havendo uma generalizada falta de ambição.

Já em 2015, em Paris, chegou-se a um acordo que, se apresenta limitaçôes, foi considerado um sucesso diplomático pelo engajamento de 195 países - o Acordo de Paris foi adotado com o objetivo principal de fortalecer a resposta mundial ao aquecimento global. $\mathrm{O}$ compromisso ocorre no sentido de manter o aumento da temperatura média global em bem menos de $2^{\circ} \mathrm{C}$ acima dos níveis pré-industriais e de envidar esforços para limitar o aumento da temperatura a $1,5^{\circ} \mathrm{C}$ acima dos níveis pré-industriais (Brasil, 2020). Apesar de os Estados Unidos terem assinado o Acordo de Paris em 2016, sua falta de apoio político posterior em muito esvaziou os objetivos do acordo. Esse fato ilustra o que Carvalho (2010) já tinha apontado como a necessidade de ampliar a base de apoio e comunicação além da CQNUMC.

A inclusão e a participação dos níveis global, nacional, regional e local das sociedades nos debates e nas açôes relacionadas ao aquecimento global são fundamentais para a responsabilização e o empoderamento dos agentes, para que haja um engajamento coletivo, necessário ao seu combate. Portanto, deve-se partir de um marco de comunicação (communication approach), segundo Evans et al. (2018), com o objetivo de estimular a participaçáo nas discussóes e tomadas de decisão, ou seja, um maior engajamento das diferentes partes, possibilitado por fluxos de informação. Dentro dos principais marcos de comunicação e com maior relevância para os tempos atuais e para a questão climática, destacam-se: i) a comunicação de riscos; ii) a comunicação ambiental; e iii) a comunicação para mudanças sociais e desenvolvimento.

A comunicação de riscos é definida como sendo a maneira como as agências governamentais e organizaçóes avaliam e gerenciam os riscos e as situaçôes de crise, além de como é feita, nesse

4. As negociações são agravadas pelos problemas conhecidos na literatura como do carona e do vazamento de carbono (Tirole, 2017).

5. O Protocolo de Quioto tinha como meta a efetiva redução de emissões dos Estados desenvolvidos por meio do financiamento de projetos redutores de emissões de GEE pelos países desenvolvidos nos países em desenvolvimento. Esse protocolo seria a expressão das responsabilidades comuns, mas diferenciadas, entre nações desenvolvidas e em desenvolvimento, demanda deste último grupo. 
contexto, a comunicação sobre a natureza da crise para os agentes envolvidos e membros em geral (Lie e Servaes, 2015). O sucesso de uma comunicação de riscos em muito depende de conseguir engajar as partes afetadas na cooperação com a gestão do risco em questão por meio de suas açôes. O papel dessa comunicação é similar ao de uma comunicação de saúde, na medida em que ambas as formas devem visar instruir, informar e motivar um comportamento autoprotetor, sempre incorporando as atualizaçóes necessárias, construindo um ambiente de confiança nas autoridades e dissipando rumores. ${ }^{6}$

A comunicação de riscos tende a ser linear, do tipo top-down, partindo de autoridades e governos para as populaçóes afetadas, com o fim de instruir e induzir à cooperação para a minimização do risco em questâo. Sterman (2008) avalia que a comunicação das mudanças climáticas tem sido feita antes nas soluçôes para esse fenômeno do que numa comunicação visando aumentar a compreensáo desse processo e dos riscos derivados. Entretanto, o autor enfatiza que a ação coletiva é necessária para reduzir as emissôes de GEE, assim como para pressionar governos a adotar políticas destinadas a essa redução e promover as capacidades comunitárias para a adaptação. Vaughan e Tinker (2009) também reconheceram a necessidade de que haja participação das comunidades afetadas, mesmo que passivamente, enfatizando que a qualidade da resposta societal em muito depende de uma comunicação efetiva e que alcance todas as camadas das população, especialmente aquelas com maior predominância de grupos vulneráveis aos riscos em questão.

Portanto, o modelo de comunicação de riscos, embora muito adequado em situaçóes pandêmicas e de desastres, pode não se revelar totalmente adequado à construçáo de uma base coletiva de conhecimentos e atitudes para as mudanças climáticas, que é um processo de crise que ocorre de forma sustentada. Necessita-se de um marco de comunicaçáo que leve a mudanças de atitudes e percepçóes e que seja socialmente compartilhado, com a participaçáo de comunidades e diferentes instâncias nas discussões e tomadas de decisão. A promoção da saúde e o marketing social têm sido apontados como um bom encaixe na comunicação de riscos. Entretanto, há limitaçôes. No caso da saúde, por exemplo, o foco maior é sobre os produtores da mensagem, diminuindo o papel da audiência, fundamental para a efetiva gestão do risco objeto da comunicação (Fiske, 1989). Ainda assim, não há dúvida de que a comunicação de riscos tem aspectos importantes a serem utilizados nas comunicaçóes de aquecimento global, principalmente quanto à informação e à educação.

A comunicação ambiental é uma nova subdisciplina no campo das ciências de comunicação, e seu objetivo é elaborar estratégias e análises de "todas as interaçôes da interaçáo humana com o meio ambiente" (Cox e Depoe, 2015, traduçáo nossa), tendo originalmente surgido nos Estados Unidos e na Europa. De acordo com essa linha, a comunicação ambiental se constitui no veículo apropriado para a nossa compreensão do meio ambiente na perspectiva de nossas relaçóes com o mundo natural, de forma a poder expressar a maneira como a sociedade responde aos problemas ambientais.

Já a comunicação para mudanças sociais e desenvolvimento pode ser vista de acordo com dois paradigmas diferentes. O primeiro seria o marco difusionista, por meio do qual

6. Vaughan e Tinker (2009), por exemplo, estabelecem: "Ideally, pandemic communication maximizes the public's capacity to act as an effective partner by encouraging prevention, promoting containment, and fostering resilience and recovery. Moreover, with an expanded role in pandemic planning and response, communication processes can prepare the public to adapt to changing circumstances or uncertainty during an emerging pandemic, educate public health partners about existing vulnerabilities (...) facilitate anticipation of surprising events, create dialogue between potentially affected populations and risk managers, and foster an environment of mutual interest". 
a comunicação tem o papel de disseminar a informação focada na eficiência ou nos efeitos, num marco do tipo top-down. O segundo seria o marco participativo, que enfatiza soluçôes participativas (bottom-up). Em ambos os paradigmas, a comunicação para mudanças sociais e desenvolvimento considera as mudanças sociais como um processo, com o fim último do desenvolvimento sustentável em níveis distintos da sociedade. Servaes e Lie (2013) preconizam a adoçáo de um marco participativo e difusionista com o conteúdo visando a mudanças que conduzam a um desenvolvimento sustentável no longo prazo, com a participação de vários níveis da sociedade.

Evans et al. (2018), numa tentativa de ampliar o trabalho de Servaes e Lie (2013), propóem um marco normativo, estrutural integrado como sendo o mais adequado para uma comunicação sobre questóes envolvendo a mudança global do clima, partindo do princípio de que todas as formas de meios e tipos de comunicação são importantes e interdependentes, com a ênfase centrada na participaçáo e no empoderamento dos cidadáos nos processos de decisão e comunicação. Assim sendo, todas as diferentes formas de comunicação brevemente descritas anteriormente têm algo a acrescentar num marco integrado.

A primeira característica importante nesse marco integrado é que a comunicação efetiva deve incorporar uma ampla participação a fim de promover a inclusão e a equidade nas discussões e tomadas de decisão sobre mudanças climáticas. O nível global se torna uma plataforma para a colaboraçáo, em que idealmente a mídia global deveria ter o papel social de informar as iniciativas e respostas de políticas nas diferentes regiôes do mundo. Essa informaçáo torna-se útil em nível regional, ao informar os aspectos regionais da sustentabilidade. Em nível nacional, as açóes e políticas nacionais de combate ao aquecimento global, numa estratégia de comunicação eficaz, podem levar ao engajamento das comunidades locais sobre as oportunidades de comunicação disponíveis dentro desse esforço nacional.

Evans et al. (2018) destacam que a mídia tem o duplo papel de prover uma plataforma para o engajamento e o empoderamento, e de atuar na vigilância, ajudando na prestaçáo de contas dos governos, dos formuladores de políticas e dos cidadãos em todos os níveis. $\mathrm{Na}$ CQNUMC, por exemplo, a mídia pode monitorar os avanços na implementação dos acordos climáticos, assim como as atividades industriais geradoras de GEE.

A comunicação das mudanças climáticas deveria engajar e empoderar os cidadãos no processo de formulação e implementação das políticas, de forma que o cidadáo comum seja empoderado para tomar decisóes afetando sua vida no presente e no futuro. A figura 1 traduz essa possibilidade de engajamento e participação.

A figura 1 mostra a maneira como um modelo de comunicação participativo e estruturalmente integrado conduz a um modelo de comunicação inclusivo e numa base de reciprocidade. A mídia, em suas formas diferentes, tem papel central no processo de comunicação, sendo um espaço para ideias e uma plataforma para o engajamento e o debate. Nesse contexto ideal, todos os participantes podem dialogar uns com os outros, com reciprocidade e iguais oportunidades para se engajar e debater. A mídia se torna um espaço de troca de ideias com a potencial participação de todos os agentes numa base de igualdade. De modo normativo, esse modelo seria o ideal para qualquer tipo de comunicação relacionada a mudanças climáticas ao se basear na igualdade e na inclusão de ideias e perspectivas de ações relacionadas a esse tema. 


\section{FIGURA 1}

Marco normativo, estrutural e integrado para a comunicação de mudanças climáticas

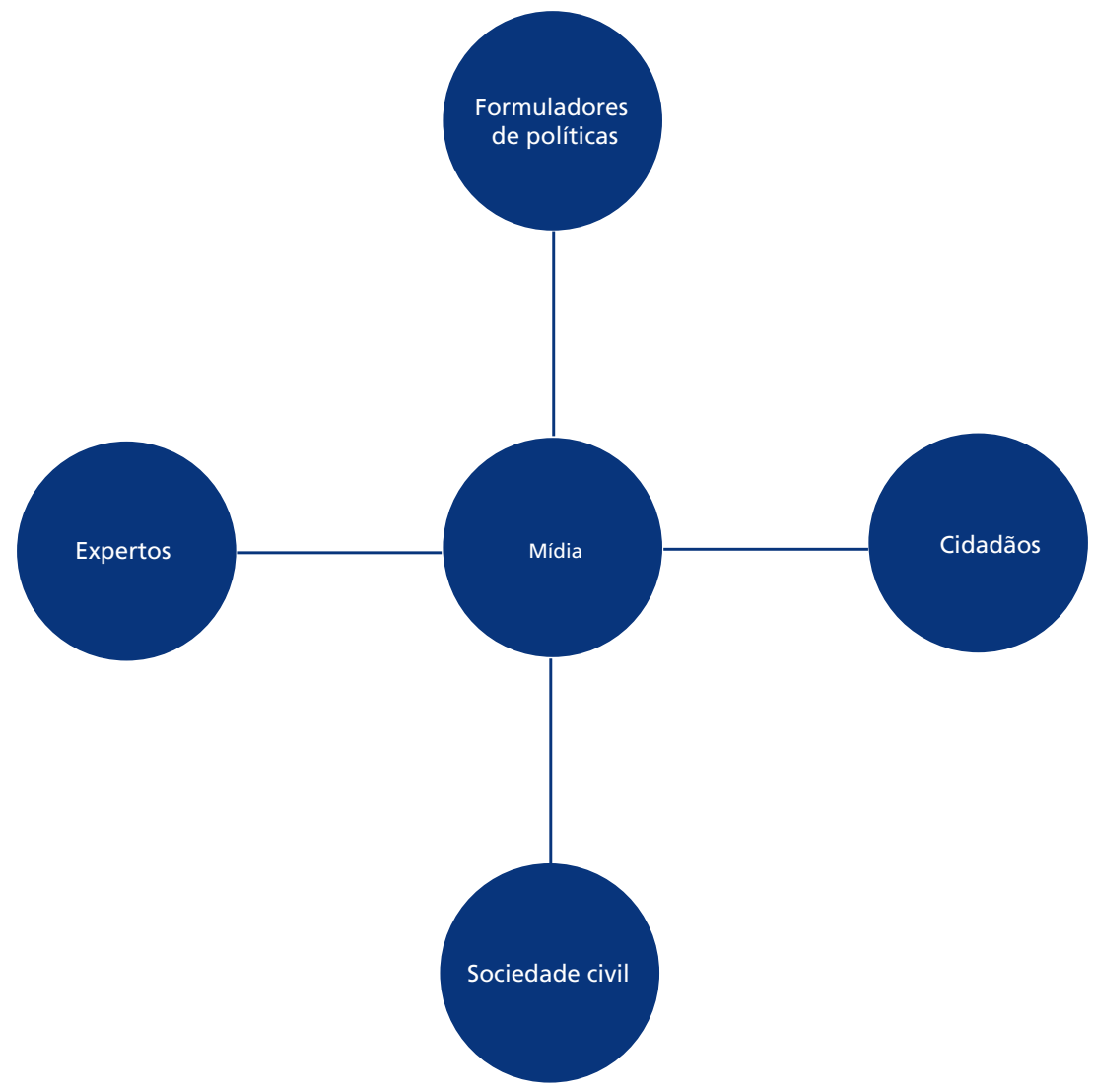

Fonte: Evans et al. (2018).

Entretanto, não existe um modelo único de comunicação que possa ser utilizado na categoria comunicação para desenvolvimento e mudanças sociais. Impóe-se a necessidade de um modelo híbrido para a comunicação das mudanças climáticas que se alicerce nas vantagens dos marcos bottom-up e top-down. Três são os requisitos necessários para que seja um bom modelo: permitir a participaçáo é o primeiro aspecto; que seja plural; e que utilize as novas tecnologias de informação e comunicação (internet e mídias sociais). Diferentemente de meios como a televisão e a imprensa, que não capacitam processos de participação pela sua linearidade intrínseca, a difusão dos meios de comunicação pela internet e das suas novas tecnologias cria oportunidades para a participação cidadã na produção e no consumo de mensagens (Castells, 2012).

Há de se destacar que, no caso das mudanças climáticas, os meios tradicionais de comunicação têm se comunicado de forma linear, ou seja, a visão oficial ou de expertos prevalece, acarretando uma participaçáo praticamente inexistente dos cidadáos comuns. Essa comunidade - formada por uma elite política, científica e econômica - alija o cidadão comum de participar nas discussóes de política e de agenda para combater o aquecimento global, tornando-o mero espectador de um processo que inevitavelmente afetará sua vida. Evans (2015) ainda vai mais longe ao apontar que a falta de envolvimento do cidadáo comum nas discussões contribui para a sua pouca compreensão do fenômeno, formando um círculo vicioso, quando a situação deveria ser de participação ativa e contribuição nos processos de decisão. 
Portanto, a participação em processos de comunicação sobre questôes acerca das mudanças climáticas teria um papel central no empoderamento do cidadão comum na responsabilidade coletiva de meios de decisão referentes a esse fenômeno, tanto local quanto globalmente.

O papel das mídias sociais resulta de sua capacidade de incentivar pequenas mudanças em direção à sustentabilidade. Isso ocorre pela troca e pelo compartilhamento de informação, podendo estimular mudanças nos diferentes níveis (Kavada, 2014) - essa mídia possibilita a interaçáo entre cidadáos e grupos de regióes diferentes, compartilhando ideias e objetivos comuns num nível horizontal. Ainda que, por si só, esse processo não vá substancialmente alterar o curso das tendências ambientais, ele pode, sim, contribuir para a tomada de pequenos passos em direçáo à sustentabilidade, por meio de mudanças nas preferências dos consumidores ou no estilo de vida. Como destacam Evans et al. (2018), o fortalecimento de redes de grupos de pressão conectados pelas novas mídias tem ajudado a sociedade civil e o ativismo social nos níveis local, nacional e global, promovendo uma verdadeira globalização a partir das bases.

\section{COMUNICAÇÃO CORPORATIVA, SUSTENTABILIDADE E AS MÍDIAS SOCIAIS}

As companhias podem e devem participar do esforço de mitigação nas emissões de GEE. Isso porque elas não só têm ainda grande participação nessas emissóes como também podem fazer escolhas tecnológicas importantes. Um estudo da organização norte-americana de pesquisas Climate Accountability Institute, por exemplo, chega ao resultado de que um grupo de vinte empresas é responsável por mais de um terço das emissôes de GEE em todo o mundo desde 1965. A análise abarca o período iniciado em 1965 até 2017. De acordo com ela, vinte empresas produtoras de petróleo, gás natural e carvão foram responsáveis por 480,16 bilhóes de toneladas de GEE liberados na atmosfera nesse período. Esse montante representa 35\% das emissóes totais de combustíveis fósseis e cimento.

A lista completa, apresentada a seguir, é composta de doze empresas estatais e oito privadas, sendo encabeçada pela estatal saudita Saudi Aramco, responsável pela emissão do equivalente a 4,38\% do total mundial no período 1965-2017. Em segundo e terceiro lugares, aparecem a americana Chevron (3,20\% do total) e a russa Gazprom (3,19\%), respectivamente. A Petrobras responde por $0,64 \%$ do total, de acordo com a tabela 1 .

O relatório aponta a responsabilidade "moral, financeira e legal" por suas emissôes acumuladas, assim como a obrigaçáo de ajudar a combater o problema. $\mathrm{O}$ estudo afirma que as empresas que "valorizam sua licença social para operar" devem se adequar à ciência climática, gerenciar os riscos corporativos e se comprometer a reduzir a produção futura de combustíveis sólidos e suas emissões, em alinhamento com o Acordo de Paris.

A participação das companhias nos acordos climáticos pode ser muito importante para garantir sua efetividade, e impóe-se uma agenda de sustentabilidade que tenha como um vetor importante a contribuição ao combate ao aquecimento global. Essa participação pode ser de natureza voluntária ou induzida por um marco regulatório mais severo. 
TABELA 1

Empresas maiores emissoras de dióxido de carbono equivalente no total global (1965-2017)

\begin{tabular}{lcccc}
\hline Empresa & Natureza & Origem & Emissões (tCO, eq bilhões) & $\%$ \\
\hline Saudi Aramco & Estatal & Arábia Saudita & 59,26 & 4,38 \\
Chevron & Privada & Estados Unidos & 43,35 & 3,20 \\
Gazprom & Estatal & Rússia & 43,23 & 3,19 \\
ExxonMobil & Privada & Estados Unidos & 41,90 & 3,09 \\
National & Estatal & Irã & 35,66 & 2,63 \\
Iranian Oil Company BP & Privada & Reino Unido & 34,02 & 2,51 \\
Royal Dutch Shell & Privada & Países Baixos e Reino Unido & 31,95 & 2,36 \\
Coal India & Estatal & Índia & 23,12 & 1,71 \\
Pemex & Estatal & México & 22,65 & 1,67 \\
PDVSA & Estatal & Venezuela & 15,75 & 1,16 \\
PetroChina & Estatal & China & 15,63 & 1,15 \\
Peabody Energy & Privada & Estados Unidos & 15,39 & 1,14 \\
ConocoPhillips & Privada & Estados Unidos & 15,23 & 1,12 \\
Abu Dhabi & Estatal & Emirados Árabes Unidos & 13,84 & 1,01 \\
Kuwait Petroleum Corporation & Estatal & Kuwait & 13,48 & 1,00 \\
Iraq National Oil Company & Estatal & Iraque & 12,60 & 0,93 \\
TotalEnergies & Privada & França & 12,35 & 0,91 \\
Sonatrach & Estatal & Argélia & 12,30 & 0,91 \\
BHP Billiton & Privada & Austrália e Reino Unido & 9,80 & 0,72 \\
Petrobras & Estatal & Brasil & 8,68 & 0,64 \\
\hline
\end{tabular}

Fonte: Climate Accountability Institute, 2019.

Uma agenda de sustentabilidade corporativa inclui uma ampla gama de questóes, que vão desde práticas "verdes" nos seus processos produtivos até a inclusão de preocupaçôes sociais. A definição mais concreta de sustentabilidade, assim como da RSE, é bastante ampla, envolvendo diversas métricas. De forma genérica, pode-se afirmar que a RSE traduz o compromisso empresarial de contribuir para o desenvolvimento econômico sustentável, ao mesmo tempo que colabora com suas partes interessadas, com as comunidades locais e com a sociedade de maneira ampla, a fim de melhorar a qualidade de vida e o meio ambiente. Esse comportamento é gerador do chamado capitalismo das partes interessadas (stakeholder capitalism). O World Business Council for Sustainable Development (WBCSD) enfatiza que o conceito de sustentabilidade tem que incorporar as três dimensóes: econômica, ambiental e social (Reilly e Hynan, 2014).

A primeira questão importante que emerge é a relacionada à informação, já que essas três dimensões em geral não são passíveis de uma mera expressão monetária. O exercício de avaliar o grau de aderência aos princípios da RSE torna-se bastante complexo, mas, mesmo assim, esse objetivo deve ser perseguido. Portanto, além dos tradicionais dados financeiros de uma empresa, e dos princípios contábeis utilizados, é necessária a análise de informação relacionada à atuação ambiental e social. Algumas iniciativas, como a Global Reporting Initiative (GRI) ${ }^{7}$ e os balanced scorecard approaches, têm sido crescentemente utilizadas.

Outra questão muito relevante diz respeito à agregação das dimensôes da performance não financeira. As empresas podem ter uma atuação boa em uma dimensão, mas não tão

7. Agência não governamental que preconiza que as empresas, além de fornecerem informações financeiras, tenham que tornar públicas as informações relativas à performance ambiental e social. 
boa em outra. Como avaliar, por exemplo, o fechamento de uma fábrica que emite muito dióxido de carbono, mas que tem um impacto significativo sobre a geração de empregos na comunidade local? São dimensóes incluídas no conceito de RSE, mas que têm direçóes opostas (Tirole, 2017). Atualmente, os fundos de investimento socialmente responsáveis colocam a sustentabilidade no cerne da sua atuaçáo, seja de forma voluntária, seja por pressóes originadas das esferas do poder político-administrativo ou dos próprios consumidores. ${ }^{8}$

O Relatório de Riscos Globais 2019, do Fórum Econômico Mundial (World Economic Forum - WEF), evidencia que a mudança do clima emerge quando associada a três dos cinco riscos globais com maior probabilidade de ocorrência e a quatro dos cinco riscos globais com maior impacto potencial negativo. Essa avaliaçáo ocorreu antes da atual pandemia que estamos vivendo, e esse ranking provavelmente seria diferente se fosse feito agora. Entretanto, cabe destacar que a crise climática ameaça a estabilidade financeira: a Força-Tarefa sobre Divulgaçôes Relacionadas ao Clima (Task Force on Climate-related Financial Disclosures - TCFD), sob a liderança do Comitê para a Estabilidade Financeira (Financial Stability Board - FSB), divulgou, em junho de 2017, recomendaçóes para informaçóes financeiras voluntárias e padronizadas com respeito às açôes voltadas para a mitigação das emissóes (CEBDS, 2018).

Retomando o foco principal deste trabalho, o papel da comunicação corporativa na divulgação das iniciativas de sustentabilidade junto às partes relacionadas já foi destacado em pesquisas anteriores (Reilly e Hynan, 2014). Muitas empresas têm utilizado as mídias sociais como um canal adicional em suas estratégias de comunicação sobre sustentabilidade. As plataformas Facebook, Twitter e YouTube informam e ao mesmo tempo promovem o diálogo, diferindo das mídias tradicionais ao permitir uma interação entre as organizações e as partes relacionadas, o que náo aconteceria no caso habitual. De acordo com Mullaney (2012), quase $70 \%$ das grandes companhias globais se utilizam das mídias sociais para suas comunicações, sendo que essa proporção se mostra ainda maior para as pequenas empresas, devido ao baixo custo de uso e à sua capacidade de alcançar consumidores num nível global.

Um número crescente de empresas tem adotado as mídias sociais como um meio de comunicação corporativa. Kaplan e Haenlein (2010) observam que as mídias permitem às empresas e aos consumidores estabelecer contato a um baixo custo e níveis de comunicação mais efetivos quando comparados aos meios de comunicação tradicionais. De fato, a maioria das grandes companhias que constam na Fortune 500 mantém contas no Facebook e no Twitter. Essa comunicação pelas mídias sociais pode ser usada para uma variedade de razóes: informar vagas de emprego disponíveis, fazer marketing de determinados produtos, educar as partes relacionadas sobre açóes de sustentabilidade apoiadas pela empresa etc. Elas podem ser usadas também para transmitir mensagens da atuação de responsabilidade social empresarial em vários outros campos, a exemplo de açôes para aumentar a inclusão social (Kietzmann et al., 2011). Como destacam Reilly e Weirup (2010), o uso das mídias sociais pode refletir um grau elevado de abertura à mudança e à inovação das empresas que delas se utilizam, provocando também estratégias de comunicação alinhadas com valores e compromissadas com tendências sociais que demandam um engajamento.

Pesquisas apontam que as empresas têm adotado, de forma crescente, a divulgação de informaçôes (contábeis ou sociais/ambientais) via redes sociais (Zhang, 2015). Uma possível

8. 0 mercado global de investimento de impacto, que considera os critérios ambiental, social e de governança (ASG), já movimenta US $\$ 502$ bilhões, considerando os ativos de 1.300 investidores de impacto no mundo. Além disso, foram captados US\$ 521 bilhões via títulos verdes no mundo, US\$ 7 bilhões somente na América Latina. 
explicação é o baixo custo, a rapidez e a flexibilidade - assim, a acessibilidade chega a todos os tipos de usuários, sejam nacionais ou não (Andrikopoulos et al., 2013). No nível internacional, vários estudos apontam que as companhias têm usado as mídias sociais com o fim de divulgar suas açóes de caráter ambiental/social. Isso ocorre num contexto em que as pessoas gastam uma parte considerável de seu tempo na internet.

Reilly e Hyan (2014), com base numa amostra de empresas globais divididas entre verdes e não verdes, analisaram as diferenças significativas entre suas formas de comunicação corporativa no que tange à sustentabilidade. Para tal, utilizaram os relatórios anuais corporativos, os relatórios de responsabilidade social corporativa e as plataformas das mídias sociais (Facebook e Twitter). As autoras do estudo chegaram à conclusão de que as empresas verdes não só são mais ativas em reportar suas atividades ambientais por meio de relatórios de responsabilidade social corporativa como também se utilizam mais frequentemente das mídias sociais para divulgar seus resultados. Outros trabalhos importantes em nível internacional também chegam a resultados semelhantes. ${ }^{?}$

\section{QUE AS EMPRESAS BRASILEIRAS ESTÃO FAZENDO NO COMBATE AO AQUECIMENTO GLOBAL}

\subsection{Como as empresas estão reagindo: Acordo de Paris}

As negociaçôes, no âmbito da Conferência das Partes (Conference of the Parties - COP) 21, realizada em Paris, resultaram numa meta de aquecimento global abaixo dos $2^{\circ} \mathrm{C}$ (Brasil, 2020). O Acordo de Paris, como é conhecido, fez com que os diferentes países apresentassem a chamada intended nationally determined contribution (INDC), expressando os compromissos voluntários nacionais de redução nas suas emissões, que, após aprovaçáo pelo Congresso, se transformam em nationally determined contribution (NDC). O Brasil, por exemplo, tem como meta alcançar, em 2025, a redução de GEE em 37\% abaixo dos níveis de 2005 e, em 2030, em 43\%. As ações para atingir essas metas se darão por meio do aumento da bioenergia sustentável na matriz energética, da restauração e do reflorestamento de florestas, além do aumento na participação das energias renováveis (Brasil, 2020).

Num contexto em que muitos países mostravam reticências em se comprometer, o Acordo de Paris pode ser considerado exitoso. As negociaçóes foram extremamente difíceis. Foi também estabelecido que o financiamento para os países em desenvolvimento superará os US\$ 100 bilhóes anuais, de acordo com decisóes tomadas na COP 15, em Copenhague, em 2009 (Tirole, 2017).

De forma geral, a conclusão chegada pelo acordo da COP 21 tem como um dos aspectos positivos o reconhecimento de que a trajetória anual das emissóes introduz riscos elevados para a saúde do planeta - e que, portanto, há a necessidade de açóes fortes e tecnologias novas para o meio ambiente. Reconhece-se também a necessidade de ajudar os países pobres e, fundamental em qualquer acordo desse tipo, de desenvolver sistemas de monitoramento da poluição e da transparência nos objetivos de cada país. Entretanto, alguns aspectos ficaram bastante abaixo das necessidades de um acordo desse tipo, sem medidas concretas (Tirole, 2017).

A questáo da eficiência econômica, entretanto, náo foi corretamente tratada. A precificação do carbono, que seria o instrumento mais adequado para a luta contra o aquecimento global,

9. Ver Zhang (2015), Androkopoulos et al. (2013) e Yu, Duan e Cao (2013). 
simplesmente não foi objeto de negociaçôes por ainda se constituir num enorme empecilho para a maioria dos países. Em relação à equidade, os países desenvolvidos concordaram com uma quantia global de financiamento, sem, no entanto, se comprometer com contribuiçóes determinadas para os países em desenvolvimento. A literatura já bem enfatizou a dificuldade de implementar acordos coletivos e o famoso "problema do carona" (Tirole, 2017).

Ao agravar esse quadro de indefinição, o acordo adia para uma data futura o compromisso concreto dos países de reduzir suas emissóes. Apesar das limitaçóes, o acordo foi considerado um sucesso diplomático, tendo sido aprovado por 195 delegaçôes, tarefa extremamente difícil no âmbito das decisóes que ocorrem no marco da Organização das Naçóes Unidas (ONU), em particular da CQNUMC.

\subsection{Acordo de Paris e o setor empresarial brasileiro}

O fato de empresas serem responsáveis por parcela substancial das emissões de GEE faz com que esse setor tenha que assumir um importante protagonismo nas metas de redução. Em contrapartida, o setor pode sofrer importantes perdas por conta da ação das mudanças climáticas. No Relatório de Riscos Globais 2019 do WEF, a crise climática aparece direta ou indiretamente associada a três dos cinco riscos globais mais prováveis e a quatro dos cinco riscos globais com maior impacto negativo. ${ }^{10}$

Crescentemente, fala-se também que a crise climática ameaça a estabilidade financeira. A TCFD, sob a liderança do FSB, apresentou, em junho de 2017, um conjunto de recomendaçôes para divulgações financeiras voluntárias relacionadas ao clima, a fim de que sejam consistentes, comparáveis, confiáveis, transparentes e de utilidade para as tomadas de decisão de bancos, seguradoras e investidores (CEBDS, 2018).

Portanto, não só pelos riscos como também pela responsabilidade social corporativa no esforço coletivo dado pelo Acordo de Paris, as companhias deverão ajustar suas emissóes de modo a contribuir para o esforço de mitigação. Vimos anteriormente que apenas vinte empresas globais são responsáveis por 35\% das emissóes acumuladas no mundo desde 1965.

No Brasil, em 2015 e 2016, as empresas brasileiras e empresas globais com filiais no Brasil - associadas ao Conselho Empresarial Brasileiro para o Desenvolvimento Sustentável $(\mathrm{CEBDS})^{11}$ e incluídas no estudo realizado pelo órgão (CEBDS, 2018) - foram responsáveis por emissóes totais de GEE de 360 milhóes e 259 milhóes de toneladas de carbono, respectivamente, o equivalente a $1 \%$ e $0,7 \%$ das emissões globais. Essas cifras, vistas desde a perspectiva brasileira, representam 17\% e 11\% das emissôes de GEE do Brasil nesses anos, respectivamente. Constata-se que, de 2015 a 2016, ocorreu uma redução de 33\% nas emissóes de GEE das empresas brasileiras, devido principalmente à alteração na produção e a desinvestimentos, em razão da queda de atividade econômica no Brasil, mas também por açôes de mitigação nas emissões de GEE. Já em 2017, essas emissôes aumentaram, com o setor representando 13\% das emissóes nacionais. De acordo com CEBDS (2018), as empresas do estudo em questão concordam com a responsabilidade social na implementação do Acordo de Paris, mas sua contribuição poderia ser mais ambiciosa e visar a açôes de longo prazo.

10. 0 relatório define como risco global um evento incerto ou condição, se ocorrer, que poderia impactar negativamente várias indústrias e países nos próximos dez anos. Disponível em: <https://bit.ly/3pWbplV>. Ver também CEBDS (2018). 11. 0 CEBDS é uma associação civil promotora do desenvolvimento sustentável das empresas brasileiras, constituída por sessenta de seus maiores grupos empresariais, representando o World Business Council for Sustainable Development no Brasil. 
Segundo CEBDS (2018), a maioria das empresas brasileiras (90\%) incluídas no estudo em questão possui metas de curto prazo até 2025 , numa expressão de alinhamento ao prazo da NDC brasileira. Entretanto, poucas já estabeleceram metas de médio e longo prazo, até 2030 e 2050, respectivamente, o que seria desejável para o próprio combate ao aquecimento global. Portanto, o estudo nos aponta a necessidade de que as empresas ampliem seus horizontes de planejamento para dar uma contribuição mais efetiva no combate ao aquecimento global.

Constatou-se também, nesse mesmo estudo (CEBDS, 2018), que as companhias incluídas têm como foco a ação climática como uma fonte de inovação, competitividade, gerenciamento de riscos e crescimento - consequentemente, elas participam no esforço de redução dado pelas metas do Acordo de Paris. De forma compatível com a natureza voluntária das açôes implementadas, os objetivos ambientais se realizam dentro de um marco empresarial de objetivos mais amplos, e não estritamente ambientais.

Importa ressaltar que, no período $2015-2016,1.340$ projetos, num investimento que excede US\$ 85,8 bilhôes, foram implementados. Esses projetos incluem principalmente eficiência energética, otimização de processos e mudanças que busquem fontes energéticas de baixo carbono. Além disso, uma ação mais forte para combater a mudança climática necessita de agentes econômicos que internalizem os danos causados ao meio ambiente quando emitem GEE. Para resolver o problema do carona, a maneira mais adequada seria a imposição da internalização das externalidades negativas das emissóes de GEE - numa ilustração da aplicação do princípio "poluidor-pagador".

Um preço único para o carbono levaria ao alcance da eficiência das ações globais, que garantiria um custo mínimo para chegarmos aos objetivos globais de redução nas emissóes de GEE. ${ }^{12}$ Diferentemente da abordagem econômica, as políticas ditas de comando e controle, estabelecendo normas diferenciadas para cada tipo de poluição, criam grandes disparidades do preço implícito do carbono, assim como são geradoras de elevados custos de transação.

Seria necessário estabelecer um preço do carbono uniforme aos agentes econômicos do mundo inteiro. As empresas, nesse caso, teriam maiores incentivos para acelerar seus processos de transição para uma economia de baixo carbono. A RSE tem sido um fator importante para as açôes empreendidas no combate ao aquecimento global, mas está longe de se constituir num marco suficiente para atacar a gravidade da situação da crise climática que se apresenta. A elaboração das políticas públicas, tributárias e ambientais deveria estar pautada pela sua integraçáo e convergência, de modo a fortalecer a competitividade do Brasil nessa nova economia.

Atualmente, vários fundos de investimento enfatizam a necessidade do investimento socialmente responsável numa perspectiva de longo prazo. A ideia de que o lucro é essencialmente uma questão intertemporal de longo prazo prevalece nos dias atuais, o que denota a consciência de que um maior lucro produzindo externalidades ambientais negativas hoje pode significar um menor lucro no futuro. Os fundos de investimento socialmente responsáveis colocam a sustentabilidade no cerne da sua atuaçáo, seja de forma voluntária, seja por pressóes originadas das esferas do poder político-administrativo ou dos próprios consumidores. Esse aspecto poderia se constituir num fator adicional a um comportamento responsável das empresas na questão do enfrentamento à crise climática.

12. A questão da desigualdade se coloca como um grande impedimento para a taxação do carbono. Em nível nacional, argumenta-se que um imposto sobre o carbono incidirá mais fortemente sobre os mais pobres; em nível internacional, um imposto único sobre o carbono não incorpora o fato de que países desenvolvidos emitiram mais no passado, ou seja, o princípio da responsabilidade histórica, também conhecida como "responsabilidade comum, mas diferenciada". 


\section{COMO AS EMPRESAS BRASILEIRAS ESTÃO COMUNICANDO}

Pelo estudo de CEBDS (2018), constatamos que as empresas brasileiras estáo participando no esforço de redução de emissão de GEE por razôes variadas, muitas vezes em linha convergente com a redução de custos, a otimização de processos e a busca de aumento de competitividade, com impactos positivos sobre a redução das emissôes (eficiência energética e otimização de processos, principalmente). Considerando o estágio preliminar deste estudo, e a exiguidade de tempo e de recursos para a identificaçáo empírica do uso de redes sociais pelas empresas incluídas na amostra de CEBDS (2018), buscam-se na literatura resultados que possam esclarecer como as empresas estão adotando estratégias de comunicação ambiental.

Um trabalho importante para ilustrar o uso de redes sociais na comunicação corporativa ambiental realizado para o Brasil foi elaborado por Viana Junior (2016). Com uma amostra das maiores empresas brasileiras que possuem perfis nas redes sociais Twitter e Facebook, ${ }^{13}$ representando e incorporando, portanto, as empresas do CEBDS em sua grande maioria, o foco do trabalho foi identificar de que forma essas companhias, a partir de seus perfis, têm utilizado essas redes para a comunicação ambiental e social. Para tal, a partir de palavras-chave tais como sustentabilidade, meio ambiente e socioambiental, foram identificadas as postagens (tweets e posts) das páginas oficiais das empresas nessas plataformas numa análise léxica. Os resultados mostram a baixa adesáo das companhias ao uso das mídias sociais para a divulgaçáo de atividades relacionadas ao meio ambiente, incluindo as açóes voltadas ao combate ao aquecimento global. Esse resultado contrasta com aqueles obtidos no estudo de Reilly e Hynan (2014), em que é apontado o uso amplo das mídias sociais pelas grandes empresas classificadas como verdes.

TABELA 2

Media de postagens ambientais e sociais das empresas (2014)

\begin{tabular}{|c|c|c|c|c|c|c|c|c|}
\hline \multirow{2}{*}{ Setor } & \multicolumn{4}{|c|}{ Twitter } & \multicolumn{4}{|c|}{ Facebook } \\
\hline & Número & Total de tweets & Tweets ambientais & $\%$ & Número & Total de posts & Posts ambientais & $\%$ \\
\hline Construção e transporte & 9 & 203,6 & 3,1 & 1,1 & 8 & 327,3 & 4,5 & 1,5 \\
\hline Consumo cíclico & 9 & 661,7 & 1,0 & 2,4 & 9 & 289,2 & 2,4 & 2,9 \\
\hline Consumo não cíclico & 5 & 512,2 & 5,4 & 1,7 & 5 & 237,2 & 4,6 & 2,2 \\
\hline Setor financeiro & 6 & $7.292,1$ & 3,3 & 0,7 & 6 & 246,8 & 3,5 & 1,9 \\
\hline Materiais básicos & 6 & $1.865,2$ & 7,4 & 7,7 & 5 & 309,8 & 43,8 & 17,4 \\
\hline Telecomunicações & 4 & $4.349,8$ & 4,5 & 0,4 & - & 267,7 & 15,3 & 5,2 \\
\hline Utilidade pública & 6 & $3.143,1$ & 2,5 & 0,7 & 7 & 327,3 & 4,5 & 1,5 \\
\hline
\end{tabular}

Fonte: Viana Junior (2016).

Como vemos na tabela 2 , a divulgação de tweets e posts de cunho ambiental, aí incluindo as questôes climáticas, mas não exclusivamente, não faz ainda parte da realidade brasileira. O número de tweets e posts nesse campo é extremamente baixo quando comparado ao número total de postagens divulgado pelas empresas. De acordo com a mesma tabela, Viana Junior (2016) destaca que o setor que apresenta, em média, o maior número de tweets no campo ambiental é o de materiais básicos, com aproximadamente sete tweets por empresa, e com 7,7\% em termos percentuais, sobrepondo-se aos demais setores. $\mathrm{O}$ mesmo resultado se apresenta na análise da divulgação no Facebook, emergindo o setor de materiais básicos como tendo, em média, o maior número de posts ambientais (44), assim como o maior percentual no total (17\%). Como esse setor é composto por segmentos de alto impacto

13. Amostra final de 45 empresas com perfil no Twitter e 40 no Facebook. 
ambiental (papel e celulose, minerais metálicos, químicos diversos), tal aspecto resulta numa elevada demanda de informaçốes sociais e ambientais pela sociedade. Entretanto, o principal resultado inequívoco aponta no sentido de que as empresas brasileiras ainda não usam as redes sociais para a divulgação de informaçôes ambientais.

Apesar dessa constatação de baixa divulgação no campo ambiental e social, Viana Junior (2016) destaca que quase 60\% das companhias participantes da amostra no seu estudo se utilizam de algum tipo de rede social para a comunicaçáo com o mercado, o que mostra o seu interesse crescente no uso de mídias sociais. Como Andrikopoulos et al. (2013) observam, muito provavelmente esse uso crescente é explicado pelo baixo custo, pela rapidez, pela tempestividade e pelo formato flexível e acessível a todos os tipos de usuários em nível nacional/internacional.

\section{CONCLUSÕES}

Dentro de um marco integrado de comunicação, as empresas poderiam desempenhar um papel educativo, de forma a engajar as partes relacionadas e, assim, amplificar os efeitos dos investimentos já realizados, com custo mínimo e amplos benefícios sociais, promovendo efeitos sinérgicos e estimulando o engajamento de outras partes no combate ao aquecimento global.

A baixa adesão das empresas brasileiras em divulgar resultados ambientais sugere um potencial papel social em usar mídias sociais para engajar as partes relacionadas, em particular os cidadãos, a fim de contribuir para questóes sobre o aquecimento global, seja pelo uso de transporte público, por participar na reciclagem, por mudanças de hábitos variados, entre outras pequenas açôes, as quais, somadas, podem ter efeitos não desprezíveis.

O empoderamento dos cidadãos na luta contra o aquecimento global é componente central para aumentar seu engajamento e sua participação nos processos de decisão, tanto localmente quanto globalmente. Um marco normativo, estrutural e integrado, de acordo com Evans et al. (2018) (figura 1), torna-se necessário e as empresas, a um custo muito baixo, podem e devem participar náo só por um dever moral como também pela sua responsabilidade social. O maior uso das mídias sociais para efeitos de comunicação ambiental é necessário para incentivar a adesão de cidadãos em mudanças sociais que levem a um futuro mais sustentável. É também veículo apropriado e desejável para promover o compartilhamento e a troca de informaçôes, além de estimular mudanças em todos os níveis.

\section{REFERÊNCIAS}

ANDRIKOPOULOS, A. et al. Internet disclosure and corporate performance: a case study of the international shipping industry. Transportation Research, v. 47, n. 1, 2013.

BRASIL. Ministério do Meio Ambiente. Acordo de Paris. Brasília: MMA, 2020. Disponível em: <https://bit.ly/3pXtX5e>.

CARVALHO, A. Media(ted) discourses and climate change: a focus on political subjectivity and (dis)engagement. Hoboken, New Jersey: John Wiley and Sons, 2010. v. 1. (Wires Climate Change).

CASTELLS, M. Networks of outrage and hope: social movements in the internet age. Cambridge: Polity Press, 2012.

CEBDS - CONSELHO EMPRESARIAL BRASILEIRO PARA O DESENVOLVIMENTO SUSTENTÁVEL. Como as empresas vêm contribuindo com o Acordo de Paris. Rio de Janeiro: CEBDS, 2018. 
COX, R.; DEPOE, S. Emergence and growth of the "field" of environmental communication. In: HANSEN, A.; COX, R. (Eds.). The Routledge handbook of environment and communication. Abingdon: Routledge, 16 mar 2015.

EVANS, H.-C. Climate-change awareness and online media in Zimbabwe: opportunities lost? In: HALVORSEN, T.; IBSEN, H.; M'KUMBUZI, V. R. P. (Eds.). Knowledge for a sustainable world: a Southern African-Nordic contribution. Cape Town: African Minds, 2015. p. 163-182.

EVANS, H.-C. et al. Communicating climate change: theories and perspectives. In: LEAL FILHO, W. et al. (Eds.). Handbook of climate change communication. Berlin: Springer, 2018. v. 1.

FISKE, J. Reading popular. London: Taylor and Francis, 1989.

KAPLAN, A. M.; HAENLEIN, M. Users of the world, unite! The challenges and opportunities of social media. Business Horizons, v. 53, n. 1, p. 59-68, 2010.

KAVADA, A. Transnational civil society and social movements. Hoboken, New Jersey: Wiley-Blackwell, 2014.

KIETZMANN, J. H. et al. Social media? Get serious! Understanding the functional building blocks of social media. Business Horizons, v. 54, n. 3, p. 241-251, May/June 2011.

LIE, R.; SERVAES, J. D. Disciplines in the field of communication for development and social change. Communication Theory, v. 25, n. 2, 2015.

MULLANEY, T. Social media is reinventing how business is done. USA Today, 16 May 2012.

REILLY, A. H.; HYNAN, K. Corporate communication, sustainability and social media: it is not easy (really) being green. Business Horizons, v. 57, n. 6, p. 747-758, 2014.

REILLY, A. H.; WEIRUP, A. R. Sustainability initiatives, social media activity and organizational culture: an exploratory study. Journal of Sustainability and Green Business, 2010.

STERMAN, J. D. Risk communication on climate: mental models and mass balance. Science, v. 322, n. 5901, 2008.

SERVAES, J. D. Communication for development: one world, multiple cultures. New York: Hampton Press, 1999.

SERVAES, J. D.; LIE, R. Sustainable social change and communication. Communication Research Trends, v. 32, p. 1-43, 2013.

TIROLE, J. The economics for the common good. Princeton, New Jersey: Princeton University Press, 2017.

VAUGHAN, E.; TINKER, T. Effective health risk communication about pandemic influenza for vulnerable populations. American Journal of Public Health, v. 99, n. 2, 2009.

VIANA JUNIOR, D. B. Disclosure socioambiental via redes sociais: um estudo nas empresas listadas no IBRX-100 da BMF\&BOVESPA. Revista de Gestáo Ambiental e Sustentabilidade, v. 5, n. 2, 2016.

YU, Y.; DUAN, W.; CAO, Q. The impact of social and conventional media on firm equity value: a sentiment analysis approach. Decision Support Systems, v. 55, n. 4, p. 919-926, 2013.

ZHANG, J. Voluntary information disclosure on social media. Decision Support Systems, v. 73, p. 28-36, 2015. 

OPINIÃO 



\section{APROVEITAMENTO ENERGÉTICO DE RESÍDUOS: UM MERCADO QUE NÃO SE PODE DESCARTAR'}

Amaro Olímpio Pereira Junior ${ }^{2}$

O Brasil produz anualmente 45 milhóes de pneus e 20 milhóes são descartados. Mais de 2 milhôes de cocos são produzidos anualmente - 1,6 milhão deles são descartados. No caso dos equipamentos eletroeletrônicos, 1,5 milhão de unidades também são descartadas. Vários outros exemplos como esses podem ser apresentados, dando uma ideia do nível de desperdício no país.

Esse é um problema grave, porque muitas vezes tais resíduos são descartados de forma inadequada, o que causa vários impactos ambientais. Além disso, a Política Nacional dos Resíduos Sólidos (PNRS), regulamentada pela Lei no 12.305/2010, determina que as empresas são responsáveis pela correta destinação dos resíduos produzem.

Uma forma de evitar os problemas causados pelo descarte inadequado dos resíduos é o que ficou conhecido como o princípio dos 3Rs: reduzir, reutilizar e reciclar. Esse princípio está totalmente alinhado com o conceito de economia circular, em que se defendem processos produtivos que contemplem redução, reutilização, recuperação e reciclagem de materiais e energia. Assim sendo, diminui-se a extração de recursos naturais, evita-se o descarte de resíduos em aterros sanitários e reduz-se a pressão sobre o meio ambiente, contribuindo também para o país atingir os Objetivos do Desenvolvimento Sustentável (ODS).

Além dos benefícios para o meio ambiente, o aproveitamento de resíduos pode gerar várias oportunidades no mercado de energia, pelo uso das waste-to-energy technologies, ou tecnologias de aproveitamento energético de resíduos. Entre as principais tecnologias, é possível destacar a incineração, a pirólise e a gaseificação.

A primeira é a mais comumente usada, pois náo requer a triagem dos resíduos. Dependendo da composiçáo do lixo, pode-se obter um composto com poder calorífico inferior (PCI) maior que $2.000 \mathrm{kcal} / \mathrm{kg}$, que é viável técnica e economicamente para o aproveitamento energético. Além disso, o resíduo da incineração pode ser utilizado como adubo orgânico. Essa é uma solução interessante para cidades com população superior a 100 mil habitantes.

1. DOI: http://dx.doi.org/10.38116/brua24art14

2. Professor adjunto do Programa de Planejamento Energético do Instituto Alberto Luiz Coimbra de Pós-Graduação e Pesquisa de Engenharia da Universidade Federal do Rio de Janeiro (Coppe/UFRJ). 
A pirólise, por sua vez, permite a obtenção de óleo sintético, carvão vegetal ou coque a partir do processamento de resíduos de biomassa, pneus ou plásticos. No caso de resíduos agrícolas, produz-se um óleo sem enxofre que pode ser usado para gerar energia elétrica, ou em motores de navios, caminhôes ou ônibus com baixa poluição atmosférica. O carvão vegetal, ou biochar, pode ser utilizado como carváo ativado, que é insumo para descontaminantes de solos, de água, clareadores dentais etc. Ademais, o resíduo aquoso pode ser usado como inseticidas naturais. Ou seja, vários mercados podem absorver os produtos e subprodutos da pirólise de resíduos de biomassa.

No processamento de pneus usados, a tecnologia da pirólise produz um óleo pesado que pode ser utilizado como asfalto ou na selagem de telhados. Como subproduto, tem-se o negro de fumo, que é insumo para a produçáo do próprio pneu, adequando-se perfeitamente ao conceito de economia circular, além de malha de aço, que serve de sucata reutilizada em indústrias siderúrgicas.

Por fim, a pirólise de plásticos também produz óleo com características muito similares às do óleo mineral, podendo ser utilizado, dessa maneira, como combustível para navios, caminhôes e ônibus, ou mesmo para a geração de energia elétrica. O subproduto é o coque, muito utilizado na indústria de cimento.

A gaseificação, por seu turno, é um processo comumente aplicado à biomassa, mas pode também ser utilizado até mesmo o carvão mineral. $\mathrm{O}$ gás de síntese, produto do processo, pode ter aplicaçôes energéticas, em substituição ao gás liquefeito de petróleo, por exemplo. Com o gás de síntese, é possível produzir combustíveis líquidos, uma tecnologia conhecida com gas-to-liquids (GTL).

Os países europeus têm voltado a atenção para essas tecnologias, uma vez que eles podem contribuir para seguir no caminho da neutralidade de carbono na economia até 2050 e também no que ficou conhecido como power-to- $X$, ou eletrificação de tudo. Nesse sentido, os óleos sintéticos desempenharão um papel fundamental. Isso porque uma economia neutra em carbono depende de geração de energia elétrica a partir de fontes renováveis, como a energia eólica e a solar - tais tecnologias têm, inclusive, se expandido bastante, não somente na Europa, mas no mundo inteiro. A questão é que são fontes que dependem das condições do tempo e, por isso, são intermitentes; assim sendo, precisam de complementação com geração de outras fontes ou com tecnologias de armazenamento de energia, como baterias, que ainda são muito caras. Dessa maneira, a geração com combustíveis sintéticos pode ser uma perfeita solução para dar confiabilidade ao sistema elétrico, com outra fonte renovável.

Também há dificuldade de fornecer combustíveis renováveis para navios, aviōes e para o fornecimento de aquecimento distrital (fundamental para manter o conforto térmico no inverno europeu). Há, além disso, a preocupação com o fornecimento de produtos químicos. Assim, aqui se aposta também na produção de combustíveis sintéticos, produzidos principalmente a partir de resíduos sólidos urbanos.

Esse é um mercado em franco crescimento, que o Brasil precisa aproveitar, porque, além de ser capaz de prevenir os impactos ambientais do descarte inadequado, o país ainda possui tecnologia e capacitação tecnológica para tal. O Programa Nacional do Álcool (Proálcool) e o Programa Nacional de Produçáo e Uso do Biodiesel (PNPB) são provas do alcance de programas de aproveitamento comercial de biomassa e resíduos de biomassa. 
Além disso, é importante destacar que as dimensôes continentais do país criam uma grande diversificação de biomassa. Na região Norte, por exemplo, destacam-se os caroços de açaí e o coco-do-babaçu; no Nordeste, a casca de coco e de castanha-de-caju; no Centro-Oeste, o sabugo e o colmo do milho e a soqueira do algodáo; no Sudeste, o bagaço, a palha da cana e a casca do amendoim; e, no Sul, a casca de arroz e a madeira de acácia. Isso para ficar em poucos exemplos de resíduos de biomassa.

O domínio das tecnologias, a disponibilidade de recursos naturais e resíduos e o apelo ambiental fazem com que esse seja um mercado promissor para o Brasil, com potencial de ganhos com o comércio internacional e grande geração de emprego e renda por meio de produtos sustentáveis. 

NOTAS DE PESQUISA 



\title{
PANORAMA ATUAL DO BRASIL \\ METROPOLITANO: O ACOMPANHAMENTO \\ DOS ARRANJOS ESPACIAIS \\ INSTITUCIONALIZADOS DO PROJETO \\ GOVERNANÇA METROPOLITANA NO BRASIL ${ }^{1}$
}

\author{
Marco Aurélio Costa ${ }^{2}$ \\ Sara Rebello Tavares ${ }^{3}$
}

\section{INTRODUÇÃO}

Desde a estruturação da Rede Ipea, uma plataforma de pesquisa em rede, por meio de um edital lançado pelo Ipea em 2011, o projeto Governança Metropolitana no Brasil vem promovendo o acompanhamento do quadro dos arranjos espaciais institucionalizados do país, envolvendo as regiōes integradas de desenvolvimento (Rides), as regiôes metropolitanas (RMs) e as aglomeraçōes urbanas (AUs).

As Rides são regiôes instituídas por meio de legislação federal complementar por envolverem municípios de mais de uma Unidade da Federação (UF). Já as RMs e as AUs agregam municípios de uma mesma UF e são criadas por meio de legislação complementar estadual.

O acompanhamento dos arranjos espaciais institucionalizados exige, portanto, a consulta, a leitura e a análise da produção legislativa de todos os 26 estados brasileiros, por meio do acesso a diferentes sites e plataformas que permitem acesso aos diários oficiais estaduais.

As informaçôes sistematizadas periodicamente pelo projeto são disponibilizadas para consulta pública na plataforma Brasil Metropolitano. ${ }^{4}$ Nela, pode-se acessar o banco de dados socioeconômicos das RMs, bem como as informaçóes jurídico-institucionais relativas às movimentações de inclusão e exclusão de municípios nessas RMs.

1. DOI: http://dx.doi.org/10.38116/brua24art15

2. Técnico de planejamento e pesquisa e coordenador de Estudos em Desenvolvimento Urbano na Diretoria de Estudos e Políticas Regionais, Urbanas e Ambientais (Dirur) do Ipea; coordenador nacional do Instituto Nacional de Ciência e Tecnologia em Políticas Públicas e Desenvolvimento Territorial (INPuT); e doutor em planejamento urbano e regional. E-mail:<marco.costa@ipea.gov.br>. 3. Pesquisadora do Programa de Pesquisa para o Desenvolvimento Nacional (PNPD) na Coordenação de Estudos em Desenvolvimento Urbano da Dirur/lpea. E-mail: <sara.tavares@ipea.gov.br>.

4. Disponível em: <www.brasilmetropolitano.ipea.gov.br>. 


\section{AS RECENTES ALTERAÇÕES NO QUADRO METROPOLITANO BRASILEIRO E O ACOMPANHAMENTO FEITO PELO PROJETO GOVERNANÇA METROPOLITANA NO BRASIL}

Em agosto de 2020, o projeto disponibilizou uma nova atualização do panorama metropolitano brasileiro, tendo como data de referência 20 de julho de 2020 .

As RMs e as AUs são instituídas com o objetivo de integrar a organização, o planejamento e a execução de funçóes públicas de interesse comum (FPICs), sendo, segundo estabelece o $\$ 3^{\circ}$ do art. 25 da Constituição Federal de 1988 (CF/1988), ${ }^{5}$ uma competência dos estados.

As Rides, por seu turno, são definidas como regióes administrativas que abrangem diferentes UFs. São criadas por legislação específica que elenca os municípios que as compóem, na qual se definem a estrutura de funcionamento e os interesses das unidades político-administrativas participantes. A competência de criar as Rides é da União, segundo o $\$ 11^{\circ}$ do art. 43 da CF/1988.

No que diz respeito à revisão atual, com data de referência de 20 de julho de 2020, náo houve alteraçôes no número de arranjos espaciais institucionalizados, permanecendo os quantitativos de 76 RMs, 3 Rides e 5 AUs.

A principal alteração observada no período foi a aprovação da Lei Complementar no 426, de 3 de abril de 2020, que dispóe sobre a RM do Recife (RMR), a qual realocou o município de Goiana na zona da mata norte. Tais movimentos de entrada e saída de municípios de arranjos institucionais são monitorados e registrados em todas as revisôes do quadro metropolitano realizadas no âmbito do projeto.

Vale destacar que, além do Ipea, existem dois órgãos que acompanham e revisam o universo metropolitano no Brasil. O primeiro é o Instituto Brasileiro de Geografia e Estatística (IBGE), que faz a revisão semestralmente. Segundo o IBGE, a finalidade principal é a identificação das unidades político-administrativas do Brasil localizadas em RMs, AUs e Rides, as quais se habilitam a um tratamento específico em função de suas particularidades de planejamento e gestáo.

A última edição disponibilizada pelo IBGE, ${ }^{6}$ no segundo semestre de 2019, não indicou alteraçôes nas unidades territoriais. Segundo o instituto, havia 74 RMs no Brasil.

A outra entidade que faz o monitoramento do quadro metropolitano é o Fórum Nacional de Entidades Metropolitanas (FNEM), uma associação civil que congrega entidades e órgãos públicos estaduais responsáveis por temas relacionados às RMs brasileiras. O FNEM, assim como o IBGE, também registrou um total de 74 RMs institucionalizadas no país.

Os números discrepantes entre Ipea, IBGE e FNEM decorrem do fato de o Ipea incluir em sua contagem duas RMs do estado do Maranhão, a saber: a RM de Grande Pedreiras (Lei Complementar Estadual no 26/1995) e a RM do Leste do Estado do Maranhão (Lei Complementar Estadual no 180/2016), ambas em vigor. A metodologia de acompanhamento do quadro metropolitano brasileiro utilizada pelo Ipea se dá, como dito anteriormente, por

5. Disponível em: <https://bit.ly/3viS6W0>.

6. A edição do segundo semestre de 2019 não apontou alterações no número de arranjos que compõem o universo metropolitano; com relação aos municípios, porém, apresentou a inclusão de novos, como o de Petrópolis, da região serrana fluminense, que voltou a integrar a RM do Rio de Janeiro, de acordo com a Lei Complementar no 184/2018. Além disso, 0 estado de Alagoas (Nordeste), com a Lei Complementar no 49/2019, incluiu o município de Atalaia à RM do Vale do Paraíba e os municípios de Igaci, Palmeira dos Índios, Estrela de Alagoas, Belém e Tanque d'Arca à RM do Agreste, totalizando dezoito municípios. Na RM alagoana de Caetés, as leis complementares nos 48 e 49, de 2019, alteraram a composição da RM, integrando a ela os municípios de Coruripe e São Miguel dos Campos. Disponível em: <https://bit.ly/2Suyuj4>. 
meio do levantamento, da leitura e da sistematização das legislaçôes estaduais, acessando a publicação da produção legislativa nos 26 estados brasileiros. Esse trabalho permite o acompanhamento não apenas do surgimento de novas unidades territoriais como também das legislaçôes que versam sobre a estrutura institucional, FPICs indicadas para a gestão e o movimento de entrada e saída dos municípios nas RMs.

A atividade periódica permite, também, identificar conflitos e incongruências no diverso universo metropolitano brasileiro. A título de exemplo, podemos citar a Lei Complementar Estadual do Alagoas no 40, de 17 de junho de 2014, que incluiu o município de Murici na RM de Maceió, embora o mesmo município já integre a RM da Zona da Mata desde 2011, conforme estabelece a Lei Complementar Estadual no 31, de 15 de dezembro de 2011, sendo que, ao longo desse período, não houve nenhuma legislação referente à saída de Murici da RM da Zona da Mata.

Algo parecido acontece com o município de Timon, que compóe a RM do Leste do Maranhão e também integra a Ride de Teresina-Timon. Nesse caso, não existe nenhuma lei que determine que um município não possa fazer parte desses tipos de arranjos institucionais, os quais envolvem diferentes estruturas de gestão. Contudo, isso demanda uma dupla convergência de diretrizes para fins de planejamento territorial, envolvendo a inserção na RM e na Ride.

O universo metropolitano atual (20 de julho de 2020) está composto, como foi dito anteriormente, por 76 RMs, 3 Rides e 5 AUs. Na somatória dos municípios, o universo é composto por 1.076 municípios metropolitanos, além de outros 232 tipificados como colar, entorno ou área de expansão metropolitana, totalizando 1.308 municípios, ou seja, quase um quarto dos municípios brasileiros. Há, ainda, 56 municípios que compóem as Rides e 74 que integram as AUs. Assim, 1.438 municípios brasileiros estão inseridos em algum arranjo espacial institucionalizado, conforme ilustra a figura 1.

\section{FIGURA 1}

Brasil: arranjos espaciais institucionalizados (jul./2020)

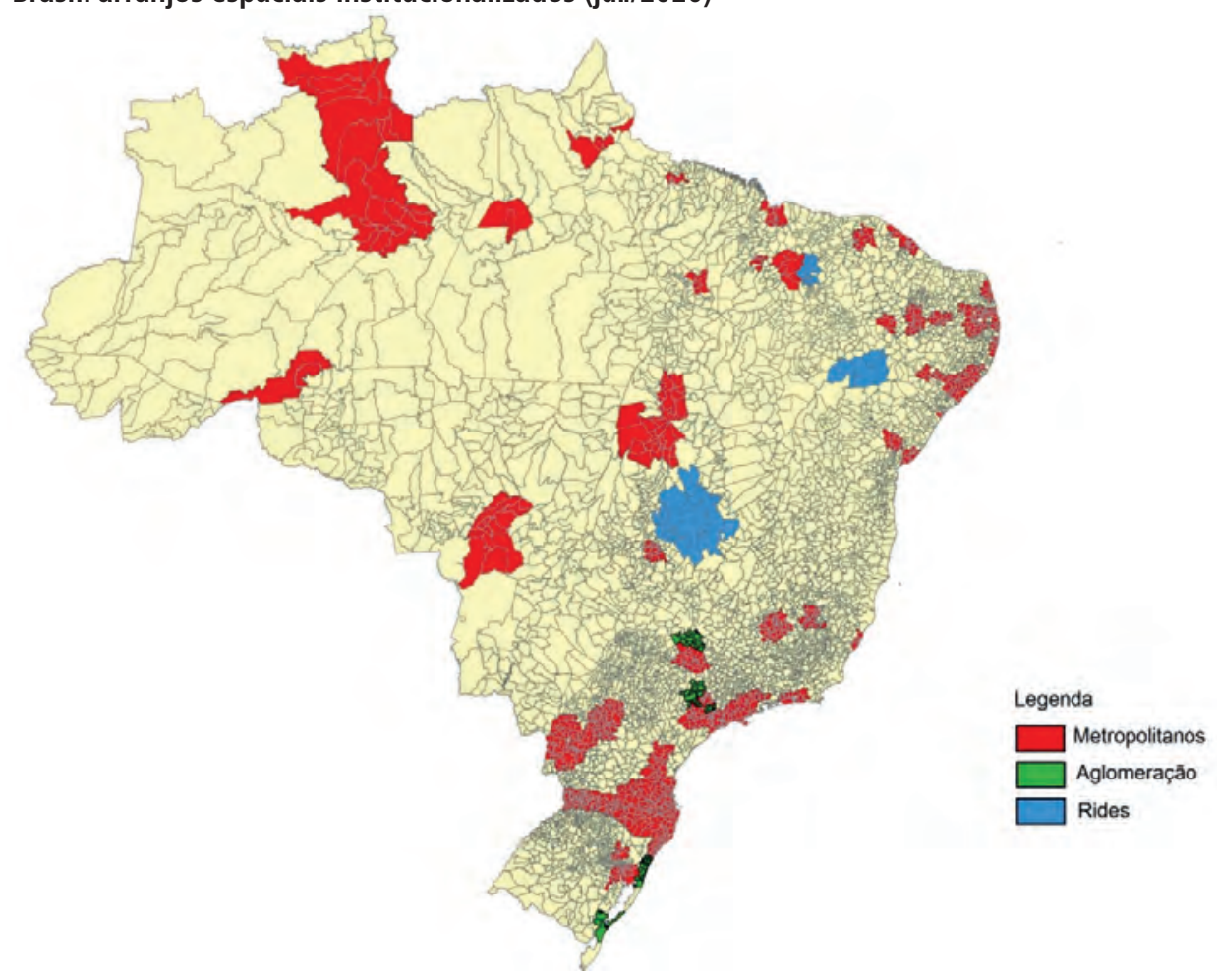

Fonte: Ipea. Disponivel em: <https://bit.ly/3oRXHjs>.

Obs.: Figura cujos leiaute e textos não puderam ser padronizados e revisados em virtude das condições técnicas dos originais (nota do Editorial). 
A distribuição regional do universo mostra que a região Nordeste possui o maior número de arranjos (33), enquanto a região Sul abriga a maior quantidade de municípios (536). O estado com maior número de RMs é a Paraíba (12), seguido por Santa Catarina (11), Alagoas (9) e Paraná (8). Santa Catarina possui a menor e a maior RM no que concerne ao número de municípios - enquanto a RM do Norte-Nordeste Catarinense possui 5 municípios, a RM de Contestado possui 45.

TABELA 1

Brasil: distribuição dos arranjos territoriais e municípios por Grande Região (jul./2020)

\begin{tabular}{lcccccc}
\hline & RMs & Municípios RMs & Rides & Municípios Rides & AUs & Municípios AUs \\
\hline Norte & 10 & 73 & - & - & - & - \\
Nordeste & 33 & 391 & 2 & 22 & - & - \\
Centro-Oeste & 2 & 34 & 1 & 34 & - & - \\
Sudeste & 10 & 274 & - & - & 3 & 49 \\
Sul & 21 & 536 & - & - & 2 & 25 \\
Total & $\mathbf{7 6}$ & $\mathbf{1 . 3 0 8}$ & $\mathbf{3}$ & $\mathbf{5 6}$ & $\mathbf{5}$ & $\mathbf{7 4}$ \\
\hline
\end{tabular}

Fonte: Ipea, 2020.

FIGURA 2

Brasil: arranjos espaciais institucionalizados por macrorregião (jul./2020)

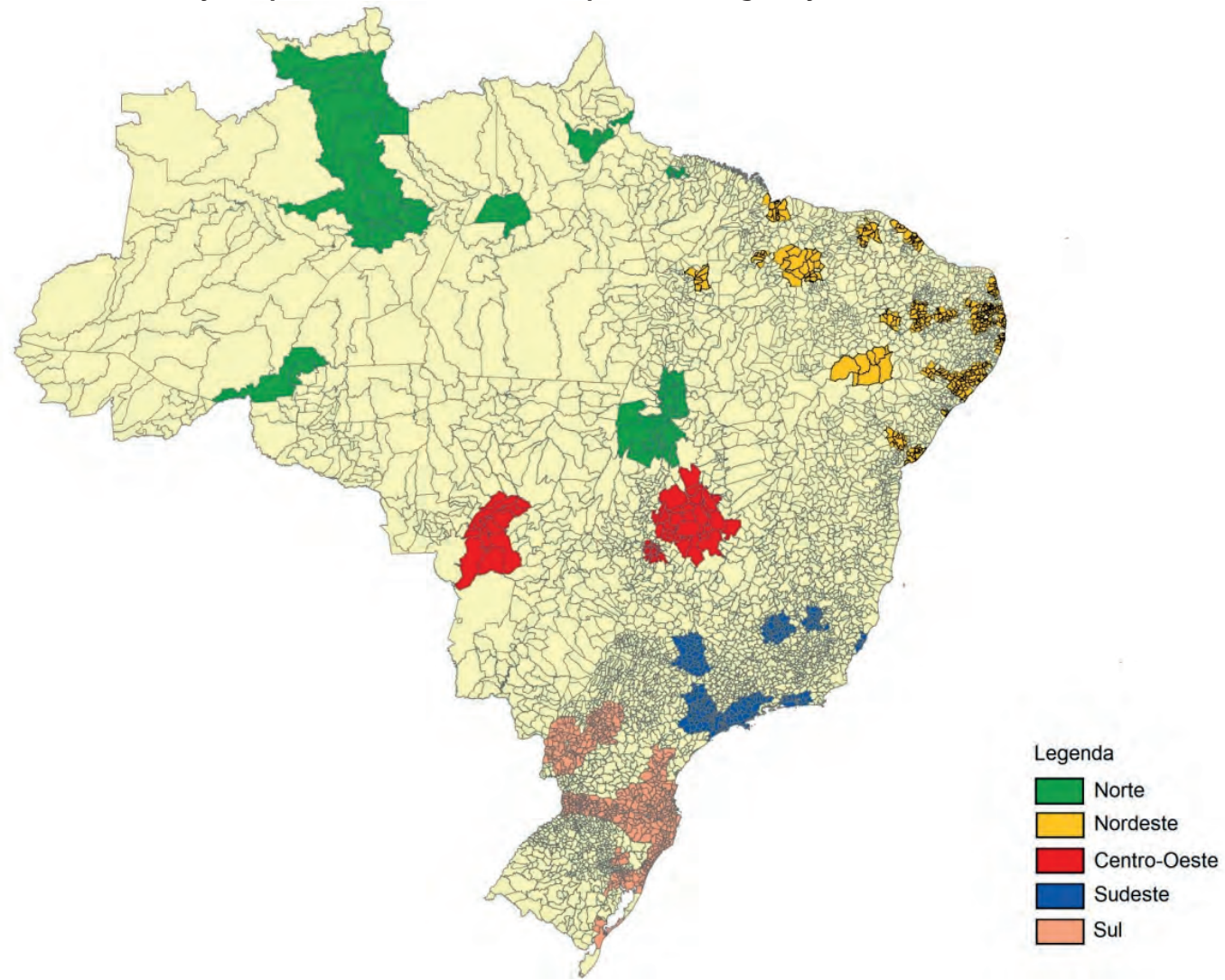

Fonte: Ipea. Disponivel em: <https://bit.ly/3oRXHjs>.

Obs.: Figura cujos leiaute e textos não puderam ser padronizados e revisados em virtude das condições técnicas dos originais (nota do Editorial).

Segundo dados disponíveis na plataforma Brasil Metropolitano, os 1.438 municípios que fazem parte dos arranjos institucionais abrigam $58 \%$ da população brasileira, o que corresponde à população estimada de 121 milhôes de pessoas, em 2018, segundo cálculos 
do IBGE. ${ }^{7}$ A RM Central (Roraima) constituía a RM de menor população, com apenas 33 mil habitantes, em contraste com a RM de São Paulo, com seus 21 milhôes.

\section{A PESQUISA REGIÃO DE INFLUÊNCIA DAS CIDADES 2018}

Além de acompanhar o quadro metropolitano brasileiro, o projeto Governança Metropolitana no Brasil tem feito comparaçóes entre o quadro institucional, decorrente da produção jurídico-administrativa dos estados brasileiros, e os estudos que procuram caracterizar o fenômeno metropolitano do ponto de vista de sua formação socioespacial.

Para acompanhar o processo socioespacial, o projeto utiliza a pesquisa Regiáo de Influência das Cidades, do IBGE, ${ }^{8}$ que traz um quadro de referência para compreender a rede urbana brasileira e, em particular, a caracterização do que seriam, efetivamente, as metrópoles brasileiras.

Na pesquisa publicada em 2020, o IBGE reconhece:

- 15 metrópoles no país, classificadas como grande metrópole nacional - a única metrópole dessa categoria corresponde ao arranjo populacional (AP) de São Paulo, com 37 municípios, dois a menos que a RM de São Paulo; e

- as metrópoles nacionais, que são duas, a saber: o AP do Rio de Janeiro (com 21 municípios, o mesmo número de municípios da RM) e o AP de Brasília (com 9 municípios, bem menos que aqueles 34 que compóem a Ride do Distrito Federal).

\section{A FASE ATUAL DO PROJETO E SUA ARTICULAÇÃO COM A POLÍTICA NACIONAL DE DESENVOLVIMENTO URBANO (PNDU)}

$\mathrm{Na}$ fase atual da pesquisa, foram produzidos 27 relatórios por parte dos quatorze arranjos que estáo inseridos no projeto. São três os componentes de pesquisa desta fase do projeto: i) um balanço das relações interfederativas estabelecidas no contexto metropolitano; ii) o acompanhamento do processo de implementação do Estatuto da Metrópole, especialmente por meio de seu principal instrumento, o Plano de Desenvolvimento Urbano Integrado (PDUI); e iii) o desafio da questão do financiamento do desenvolvimento urbano-metropolitano.

O material produzido pela pesquisa - que inclui, além dos relatórios, a publicação do quinto livro proveniente do projeto Governança Metropolitana no Brasil - está sendo utilizado para subsidiar o processo de construção da PNDU, fruto de uma importante parceria firmada entre o Ministério de Desenvolvimento Regional (MDR) e o Ipea. O quinto livro da série será publicado com apoio do MDR, no âmbito do Termo de Execução Descentralizada no 71/2019, estando seu lançamento previsto para o segundo semestre de 2021.

Informaçôes sobre o processo de implementação do Estatuto da Metrópole nas RMs brasileiras, as articulaçóes interfederativas e as experiências voltadas para viabilizar o financiamento urbano-metropolitano estão sendo sistematizadas pela equipe e estarão, em breve, disponibilizadas para o público interessado.

7. Segundo o IBGE, as estimativas das populações residentes nos 5.570 municípios brasileiros, com data de referência em 1 - de julho de 2018, foram de 208,5 milhões de habitantes, a uma taxa de crescimento populacional de 0,82\% entre 2017 e 2018, de acordo com a projeção da população (revisão 2018).

8. Disponivel em: <https://bit.ly/2RMJKHE >. 



\title{
IRRIGAÇÃO E DIVERSIFICAÇÃo DA RIQUEZA'
}

\author{
Zenaide Rodrigues Ferreira ${ }^{2}$ \\ José Eustáquio Ribeiro Vieira Filho ${ }^{3}$
}

Esta nota tem como objetivo apresentar a linha de pesquisa acerca da irrigação e da diversificação da riqueza, com o intuito de aprofundar-se em temas correlatos da economia agropecuária brasileira, mas fundamentalmente no Semiárido, região que engloba o maior bolsão de pobreza do país.

Nesse contexto, já existem diversos produtos produzidos. O primeiro deles refere-se à elaboração do capítulo Projetos públicos de irrigação: presença institucional, fruticultura e impactos produtivos, que faz parte do livro Uma Jornada pelos Contrastes do Brasil: cem anos do Censo Agropecuário, publicado pelo Ipea no segundo semestre de 2020. O segundo trabalho é a versão ampliada do estudo como Texto para Discussão, que já se encontra sob apreciação do editorial do Ipea. O terceiro trabalho é o artigo submetido à Revista de Política Agrícola (RPA), do Mapa. O artigo foi publicado no primeiro volume de 2021 da revista.

Como os trabalhos citados não esgotam o contexto do termo de referência, a continuidade da pesquisa se dá no escopo de buscar avaliar os gastos públicos em irrigação na região Nordeste do país. Essa nova pesquisa visa contribuir para a discussão a respeito do melhor planejamento da irrigação pública por meio da avaliação da efetividade do gasto público na referida atividade. A seguir, apresenta-se uma breve contextualização da nova etapa da pesquisa.

A eficácia e a efetividade de políticas públicas estão relacionadas ao uso mais eficiente dos recursos públicos, no sentido de reduzir ao máximo a inequidade na distribuiçáo de benefícios e de custos originados pela alocação do recurso. A avaliação adequada dessas políticas é a melhor forma de medir sua eficiência, além de acompanhar os resultados de sua execução.

Instituídos como políticas públicas, os projetos públicos de irrigação (PPIs), que correspondem a um dos instrumentos da Política Nacional de Irrigação, Lei no 12.787 (Brasil, 2013), configuram-se como uma importante ferramenta de promoção de desenvolvimento local e regional, principalmente em regióes com baixos indicadores sociais e econômicos,

1. DOI: http://dx.doi.org/10.38116/brua24art16

2. Pesquisadora do Núcleo de Estudos de Economia Agrícola (NE2AGRO) na Diretoria de Estudos e Políticas Regionais, Urbanas e Ambientais (Dirur) do Ipea. E-mail: <zenaide.r.ferreira@gmail.com>.

3. Técnico de planejamento e pesquisa na Dirur/lpea; diretor de programa da Secretaria Executiva do Ministério da Agricultura, Pecuária e Abastecimento (Mapa); e professor do Programa de Pós-Graduação em Agronegócio (Propaga) da Universidade de Brasília (UnB) e em Economia da Universidade Federal de Viçosa (UFV).E-mail: <jose.vieira@ipea.gov.br>. 
além de amenizarem o risco climático inerente à atividade agropecuária, em especial nas regiôes de baixa ou irregular distribuição das chuvas.

O desenvolvimento dos PPIs é complexo, burocrático e envolve etapas onerosas concebidas por meio de recursos públicos nas fases de construçáo, implantação e emancipação dos projetos (Alves e Vieira Filho, 2019). A etapa de construção, que compreende a aquisiçáo de terras e a instalação da infraestrutura de irrigação, é a mais dispendiosa. O assentamento de famílias nos PPIs também é oneroso tanto sob o aspecto financeiro quanto sob os aspectos jurídicos e culturais que envolvem esse processo.

Depois de efetuada a construção do perímetro, a manutenção e a expansão de áreas implantadas são processos relativamente menos dispendiosos, mas não menos importantes, pois são essenciais para que os PPIs atinjam um patamar mínimo de autossuficiência por meio de suporte às atividades, tais como pesquisa, assistência técnica, organizaçôes de mercado, entre outros fatores dependentes dos recursos públicos. Isso porque é preciso garantir os investimentos necessários que viabilizem tais atividades, no caso de ainda náo ter ocorrido transferência de gestão dos PPIs.

Embora oneroso, o gasto público em projetos de infraestrutura hídrica de irrigação no Brasil corresponde a uma parcela pequena nas despesas da agricultura em geral, náo passando de $7 \%$ delas. A despesa pública com irrigaçáo no Brasil caiu de forma expressiva a partir dos anos 1990. Tal queda pode ser justificada não só pelo movimento de emancipaçáo dos projetos públicos de irrigação sob administração da Companhia de Desenvolvimento dos Vales do São Francisco e do Parnaíba (Codevasf) no fim nos anos 1980 e início dos anos 1990, mas também por ser um período que marca a conclusão de implantação de diversos projetos públicos de irrigação iniciados na década de 1980 (STN, 2020).

A partir de 2002, a despesa líquida com irrigação apresentou valores anuais abaixo de R $\$ 2$ milhóes. Comparada ao produto interno bruto (PIB) do agronegócio brasileiro, calculado pelo Centro de Estudos Avançados em Economia Aplicada (Cepea, 2020), em 2019, tal despesa correspondeu a 0,007\% do PIB agrícola. Vale ressaltar que a maior parte da despesa pública com irrigação, uma média de 79\%, foi empenhada no Nordeste, região com maior concentração de PPIs no Brasil.

A despesa pública com irrigação certamente associa-se ao desempenho operacional e produtivo dos perímetros irrigados (Alves e Vieira Filho, 2019). Avaliar esse dispêndio é uma forma de justificar o uso do recurso público em termos dos possíveis benefícios econômicos e sociais associados a tal atividade. Questiona-se: é possível melhorar a eficiência do gasto público na atividade irrigada? Portanto, a pesquisa se dá no âmbito da avaliação do gasto público com irrigação na região Nordeste, onde está localizado o maior percentual de PPIs no Brasil.

Para tanto, é importante fazer um levantamento dos principais indicadores de resultados de desempenho dos PPIs e, a partir deles, propor uma metodologia adequada para medir o alcance dos objetivos em função da alocação do recurso público. A hipótese que norteia essa pesquisa é que a eficiência do uso do recurso público na atividade irrigada pode melhorar o aproveitamento das áreas implantadas, consolidando arranjos produtivos existentes. Sendo assim, busca-se aumentar o debate em torno do tema central da irrigaçáo e contribuir para o planejamento das políticas públicas em conformidade com os critérios equitativos de alocação de recursos públicos. 


\section{REFERÊNCIAS}

ALVES, E. R. A.; VIEIRA FILHO, J. E. R. O que se espera da irrigação para o Nordeste? In: VIEIRA FILHO, J. E. R. et al. (Org.). Diagnóstico e desafios da agricultura brasileira. Rio de Janeiro: Ipea, 2019.

BRASIL. Lei no 2.787, de 11 de janeiro de 2013. Dispóe sobre a Política Nacional de Irrigação e dá outras providências. Diário Oficial da Uniáo, Brasília, 14 jan. 2013. Disponível em: $<$ https://bit.ly/3hcWba5>.

CEPEA - CENTRO DE ESTUDOS AVANÇADOS EM ECONOMIA APLICADA. PIB do agronegócio brasileiro de 1996 a 2019. Piracicaba: Cepea, 2020. Disponível em: <https:// bit.ly/2PdYZVi>.

STN - SECRETARIA DO TESOURO NACIONAL. Dados orçamentários: irrigação. Brasília: STN, 2020. Disponível em: <https://bit.ly/3amfojV>. Acesso em: fev. 2020. 



\section{CONDICIONANTES DA EXPORTAÇÃO BRASILEIRA DA PECUÁRIA DE LEITE ${ }^{1}$}

Felipe Pinto da Silva²

José Eustáquio Ribeiro Vieira Filho ${ }^{3}$

Esta nota tem como objetivo apresentar a pesquisa no âmbito do termo de referência de concessão de bolsa referente ao projeto Rede de Pesquisa Integrada Ipea-Mapa, que criou o $\mathrm{NE}^{2} \mathrm{AGRO}$ Ipea-Mapa. O NE²AGRO tem o propósito de debater diversos temas sensíveis ao setor agropecuário. Como produto derivado, publicou-se um Texto para Discussáa do Ipea com o título Avaliação de Impacto do Programa de Agricultura de Baixo Carbono no Brasil. Além disso, atividades de assessoramento, com dados estatísticos e informaçóes, são realizadas junto ao Mapa. Reunióes são feitas com o Observatório da Agropecuária Brasileira (dentro da Secretaria de Inovação, Desenvolvimento Rural e Irrigação) e há a criação de indicadores socioeconômicos da agricultura familiar (na Secretaria de Agricultura Familiar e Cooperativismo).

O próximo tema a ser aprofundado será a produção pecuária de leite no Brasil. A pecuária leiteira vinha ensaiando uma expansão em 2019, de acordo com a base de dados da Food and Agriculture Organization (FAO) ${ }^{4}$ a Food and Agriculture Organization Corporate Statistical Database (Faostat), acessada em 2020. A produção mundial de leite em 2019 chegou a 852 milhôes de toneladas, principalmente devido à expansão da produçáo de alguns países específicos, como Índia, Paquistão e Brasil. Essa dinâmica, no caso brasileiro, muito se deve ao aumento do estoque de vacas ordenhadas, facilitado pelo melhoramento das condiçóes de pastagens no referido ano. Em 2020, observou-se a conquista de novos mercados externos, celebrados por diversos acordos - há o desenrolar do acordo entre a União Europeia e o Mercado Comum do Sul (Mercosul), a abertura do mercado chinês para empresas produtoras de lácteos, a abertura do mercado egípcio, entre outros. Esse cenário contrasta com o longo contexto de crise vivido no passado pelo setor.

1. DOI: http://dx.doi.org/10.38116/brua24art17

2. Pesquisador do Núcleo de Estudos de Economia Agrícola (NE²AGRO) na Diretoria de Estudos e Políticas Regionais, Urbanas e Ambientais (Dirur) do Ipea. E-mail: <dasilva.felipe@outlook>.

3. Técnico de planejamento e pesquisa na Dirur/lpea; diretor de programa da Secretaria Executiva do Ministério da Agricultura, Pecuária e Abastecimento (Mapa); professor do Programa de Pós-Graduação em Agronegócio da Universidade de Brasília (Propaga/UnB) e em Economia da Universidade Federal de Viçosa (UFV). E-mail: <jose.vieira@ipea.gov.br>.

4. Disponível em: <http://www.fao.org/faostat/en/\#home>. Acesso em: 16 ago. 2020. 
Diversos estudos, como os de Nascimento et al. (2012) e Gonçalves et al. (2008), apontaram que a pecuária leiteira no Brasil, nos anos 2000, passou por várias mudanças produtivas, com o aumento da produtividade e da eficiência a partir do uso de diferentes critérios, que combinam volume e qualidade na produção de leite. Esses fatores, junto à desvalorizaçáo da moeda doméstica e à crise argentina de 2002, que impactou duramente a produção de leite do país, deram início à trajetória de crescimento da produção brasileira de leite até 2015 (Moraes e Bender Filho, 2017). O Brasil, entretanto, continuava dependente de importaçóes de produtos lácteos, já que ainda era incapaz de suprir a sua demanda interna.

A dependência do mercado externo se acentua principalmente depois de 2009, devido à redução da carga tributária e das tarifas alfandegárias dos itens lácteos da Argentina e do Uruguai, tornando os produtos desses países mais competitivos e criando incertezas para os produtores nacionais (Moraes e Bender Filho, 2017). No entanto, esses reverses não reverteram a trajetória ascendente da produção brasileira; isso só ocorreria em 2015, ano que marca o fim desses ganhos produtivos. Explica-se essa reversão de tendência devido a uma queda acentuada no preço real do leite (alcançando o menor valor no período de 2000 a 2014), a aumentos constantes nos custos de produção e a preços internacionais mais baixos (Carvalho et al., 2017). Essa crise se aprofunda em 2016, um ano de grande instabilidade nos preços relacionados a movimentos sazonais, agravada pela crise econômica no Brasil, que diminuiu o mercado interno. A produçáo brasileira de leite volta a aumentar levemente somente em 2018. Ainda assim, o Brasil é notoriamente um dos maiores produtores mundiais de leite, segundo a Faostat.

Em 2019, o Brasil apresenta um dos maiores crescimentos observados entre os maiores produtores no período 2018-2019 (3,5\%), abrigando um dos maiores rebanhos produtivos do mundo, atrás apenas da Índia. O total das exportaçóes brasileiras em 2019 foi de US \$ 37,58 milhões ( $5 \%$ da produção mundial), uma variação positiva de $0,5 \%$, em comparação com 2018, equivalendo a um total de 20.565,31 t (Comexstat, 2020).

Os principais destinos do leite brasileiro são Argélia, Emirados Árabes, Estados Unidos e Filipinas, representando, respectivamente, $23 \%, 11 \%, 8,1 \%$ e $7,8 \%$ do total exportado. Mesmo com esses números, o Brasil não se enquadra entre os maiores exportadores de lácteos, sendo um importador líquido. Segundo a Comexstat (2020), a balança comercial no setor é bastante desfavorável, apresentando um deficit de cerca US\$ 263 milhóes em 2019. Os produtos importados são de maior valor agregado, tendo como principal origem a Argentina e o Uruguai.

Vale salientar que, no primeiro semestre de 2019, a conjuntura externa foi muito positiva para o setor brasileiro. Pode-se elencar o preço internacional do litro de leite superior aos patamares históricos, o que implicou uma relaçáo favorável entre o preço do item e os custos com alimentação. Percebe-se que há uma reversão a partir de setembro, permanecendo dessa maneira até os dois primeiros meses de 2020 - mesmo assim, o setor fechou 2019 com um crescimento entre 2\% e 2,5\% (Carvalho, Rocha e Carneiro, 2020). Houve ainda uma seca no primeiro semestre na Oceania, principalmente na Austrália, limitando sua capacidade de exportação, já que a qualidade da pastagem diminuiu e houve escassez de água, contribuindo para a alta mundial de preços.

O terceiro trimestre de 2019 iniciou-se de maneira promissora. Houve, porém, uma reversão de tendência dos custos da produção de leite, potencializada pela crise provida pela pandemia da Covid-19 em 2020, compelindo o mundo a adotar políticas de isolamento 
social, com imenso impacto econômico e social. Essas mudanças impóem condicionantes ao mercado mundial de lácteos e um novo quadro de incertezas constrange a pecuária brasileira de leite. Entretanto, os principais condicionantes das exportaçóes devem estar claros, uma vez que poderão municiar os formadores de políticas públicas de informaçôes para a tomada de decisóes mais acertadas, principalmente no contexto atual de abertura de diversos mercados para os produtos lácteos brasileiros.

Nesse contexto, é nítida a necessidade de estudos que avaliem como problema o seguinte questionamento: quais são os principais condicionantes para o mercado internacional de lácteos e em que contexto se insere a economia brasileira? Sendo assim, o objetivo do estudo é analisar os fatores e/ou as variáveis determinantes da oferta de exportação da pecuária leiteira do Brasil. Dessa maneira, se buscará entender em que medida diversas variáveis influenciam a dinâmica produtiva. A principal hipótese de trabalho é que a renda, o preço, a distância geográfica, a taxa de câmbio e o indice de liberdade de negócios, entre outras características a serem elencadas, explicam a oferta de exportação praticada pela pecuária brasileira de leite. O método a ser trabalhado será a estimação de um modelo gravitacional. Espera-se, com os resultados, contribuir para a difusão e a consolidação de informaçóes relevantes à reformulação de políticas setoriais, bem como à promoção dos negócios nessa cadeia produtiva.

\section{REFERÊNCIAS}

CARVALHO, G. R. et al. Nota de conjuntura: leite e derivados. Juiz de Fora: Embrapa Gado de Leite, jan. 2017.

CARVALHO, G. R.; ROCHA, D. T. da; CARNEIRO, A. V. Indicadores: leite e derivados, v. 11, n. 100, 2020. Juiz de Fora: Embrapa Gado de Leite, 2020.

CILEITE - CENTRO DE INTELIGÊNCIA DO LEITE. Leite em números: produção de leite no Brasil. [s.l.]: CILeite, 2019. Disponível em: <https://bit.ly/2SGbwpn>. Acesso em: 16 ago. 2020.

FAO - FOOD AND AGRICULTURE ORGANIZATION. Overview of global dairy market developments in 2019. Dairy Market Review, Mar. 2020. Disponível em: <https://bit. ly/3w270A1>. Acesso em: 16 ago. 2020.

GONÇALVES, R. M. L. et al. Analysis of technical efficiency of milk-producing farms in Minas Gerais. Economia Aplicada, v. 12, n. 2, p. 321-335, 2008.

MORAES, B. M. M.; BENDER FILHO, R. Mercado brasileiro de lácteos: análise do impacto de políticas de estímulo à produção. Revista de Economia e Sociologia Rural, v. 55, n. 4, p. 783-800, out./dez. 2017.

NASCIMENTO, A. C. C. et al. Eficiência técnica da atividade leiteira em Minas Gerais: uma aplicação de regressão quantílica. Revista Brasileira de Zootecnia, v. 41, n. 3, p. 783-789, 2012.

SILVA, F. P. da; VIEIRA FILHO, J. E. R. Avaliaçáo de impacto do programa de agricultura de baixo carbono no Brasil. Brasília Ipea, 2020. (Texto para Discussão, n. 2568). 



\title{
ESTUDO COMPARADO DE ORGANIZAÇÃO E ADENSAMENTO DE CADEIAS PRODUTIVAS E SEUS INDICADORES: UMA ANÁLISE DAS CÂMARAS SETORIAIS ENTRE 1991, 2006 E 2017
}

\author{
Maicon Gonçalves Monteiro² \\ Helinton José Rocha ${ }^{3}$ \\ Marlon Vinícius Brisola ${ }^{4}$
}

\section{INTRODUÇÃO}

O agronegócio pode ser entendido como a combinação de todas as operaçôes de produção e distribuição de suprimentos agrícolas; das operações de produção nas unidades agrícolas ou agroindústrias; e de armazenamento, processamento e distribuição dos produtos agrícolas e itens ou subprodutos oriundos deles (Davis e Goldberg, 1957). No Brasil, o agronegócio é considerado um dos principais setores que impulsionam a economia do país, transformando-se de forma significativa nas últimas décadas.

A multiplicidade de cadeias produtivas organizadas e competitivas caracteriza a agropecuária brasileira quando comparada a outros países tropicais. Nas últimas três décadas, muitas delas passaram por mudanças significativas na escala e no seu grau de adensamento e complexidade, principalmente devido ao aumento da produtividade, da sustentabilidade e das demandas internacionais (Jank, Zerbini e Cleaver, 2018).

É importante destacar que o desempenho do agronegócio brasileiro sempre teve uma ligação com as açôes do Estado no que tange ao provimento de recursos financeiros e à condução de políticas públicas voltadas ao setor (Fiep, 2016). Dessa forma, quando o Estado muda a maneira de atuar, modificações na organização do agronegócio também passam a ser necessárias.

1. DOI: http://dx.doi.org/10.38116/brua24art18

2. Pesquisador do Núcleo de Estudos de Economia Agrícola (NE²AGRO) na Diretoria de Estudos e Políticas Regionais, Urbanas e Ambientais (Dirur) do Ipea; e mestrando no Programa de Pós-Graduação em Agronegócios da Universidade de Brasília (Propaga/UnB).E-mail: <maicongoncalves675@gmail.com>.

3. Coordenador-geral de apoio às câmaras setoriais e temáticas no Departamento de Estudos e Prospecção da Secretaria de Política Agrícola do Ministério de Agricultura, Pecuária e Abastecimento (Mapa).E-mail: <helinton.rocha@agricultura.gov.br>. 4. Doutor; e professor no Propaga/UnB.E-mail:<mvbrisola@gmail.com>. 
Nessa perspectiva, Júnior et al. (2009, p. 185) destacam que "a abundância de recursos naturais, clima favorável e a evolução biotecnológica e da tecnologia mecânica sempre foram fatores-chave para o seu bom desenvolvimento". Igualmente, o compartilhamento de benefícios, a organização e a disponibilidade de informaçôes de mercado por meio de tecnologias organizacionais para a tomada de decisão dos agricultores e a condução harmônica dos interesses entre os diferentes agentes das várias cadeias produtivas existentes passaram a ser cada vez mais importantes.

Nesse contexto, as câmaras setoriais do Mapa surgem como importantes fóruns de discussão adequados à busca de soluçôes ao desenvolvimento setorial e dos diversos agentes das cadeias produtivas (Brasil, 2019).

As câmaras tiveram sua origem na coordenação de instrumentos fundamentais de política agrícola nacional que, por si, explicam a causa de seus sucessos em diversas cadeias produtivas. Entre esses instrumentos, destacamos a pesquisa agropecuária, a assistência técnica, o cooperativismo, a conformidade dos insumos agropecuários, o crédito rural e tantos outros estabelecidos a partir da Lei Agrícola (Lei no 8.171, de 17 de janeiro de 1991) "como uma primeira tentativa de se estabelecer uma legislação de política agrícola no país" (Takagi, 2000, p. 14). Juntamente com as câmaras setoriais, criava-se o Conselho Nacional de Política Agrícola.

No texto básico da Lei Agrícola, o art. 3o (objetivos) e o art. 4ํㅡ (açóes e instrumentos) ilustram que o conselho deve equacionar os fatores de sustentabilidade que afetam a produtividade dos sistemas de produção, a estabilidade de seus fatores e a distribuição dos benefícios das cadeias de valores do agronegócio (Brasil, 1991).

$\mathrm{Na}$ ocasiāo em que as câmaras foram criadas, tratava-se de um período no qual a participação direta do Estado nas atividades produtivas encontrava-se em exaustão, e as açôes do setor privado deveriam reverter-se a um entendimento junto ao Executivo governamental (Júnior et al., 2009). Portanto, assim como corrobora Takagi (2000), tais câmaras setoriais surgem num ímpeto de proporcionar um entendimento das necessidades dos diversos setores agrícolas, de forma independente, com o setor público gerador de políticas públicas.

O Brasil é detentor de uma cultura e uma história econômica que valorizaram e priorizaram produtos oriundos de cadeias produtivas específicas do agronegócio, desenvolvendo, portanto, umas mais que outras, tais como as cadeias do algodáo e de aves e suínos, que têm o seu desenvolvimento mais acentuado que as da cachaça, de fibras naturais e de ovinos e caprinos (Brasil, 2019).

Tal realidade, contudo, também depende do nível de organização de cada cadeia produtiva, uma vez que muitas dessas cadeias se mostram fragilizadas pela insuficiência de assistência técnica, pela insustentabilidade econômica da indústria de processamento, pela evasão fiscal em grande parte dos processos e pela falta de inovação tecnológica, entre outros fatores que impactam o nível de informalidade na comercialização, na produçáo e no grau de envolvimento com a exportação (Freitas, Neto e Scalco, 2014; Santos et al., 2019; Schmidt e Silva, 2018; Teixeira et al., 2018).

Diante desse contexto, se faz oportuno realizar uma pesquisa que busque levantar os sucessos e insucessos decorrentes do trabalho das cinco cadeias produtivas citadas (algodão; aves e suínos; cachaça; fibras naturais; e ovinos e caprinos) nas últimas décadas e fazer uma 
análise comparativa entre elas, visando, sobretudo, destacar a eficiência e a eficácia das ações do Estado em suas demandas específicas.

Isso possibilitará a indicação dos desafios a serem enfrentados e as estratégias a serem adotadas nos próximos anos pelos interessados no setor, bem como quais políticas públicas devem ser priorizadas pelos governos e qual o grau de envolvimento dessas políticas nos demais setores do agronegócio.

\section{OBJETIVO GERAL}

Como imperativo, o estudo busca atender a essa inter-relação contextual e, por meio de uma análise comparada entre cadeias mais desenvolvidas e menos desenvolvidas do agronegócio, orientar a pesquisa pelo seguinte objetivo geral.

- Comparar os principais indicadores de desempenho ${ }^{5}$ das cadeias de cachaça, fibras naturais e ovinos e caprinos com os indicadores das cadeias de algodão e aves e suínos, com o intuito de identificar a eficácia das políticas públicas decorrentes das demandas e estratégias estabelecidas nas câmaras setoriais e temáticas do Mapa que afetaram o desempenho do setor entre 1991, 2006 e 2017.

\section{OBJETIVOS ESPECÍFICOS}

- Levantar, em documentos públicos e privados, assim como informaçôes dos censos de 1991, 2006 e 2017, o nível de informalidade na comercialização e produção, além do nível de exportação e organização da cadeia, de forma que se revelem as características e a evolução das cadeias de cachaça, fibras naturais, ovinos e caprinos, algodão e aves e suínos entre 1991, 2006 e 2017.

- Identificar, ao longo do período de tempo em análise, as principais demandas das câmaras setoriais e temáticas aderentes ao setor das cinco cadeias em questão e as principais políticas públicas e ações privadas decorrentes.

- Comparar os efeitos das demandas e políticas nos diferentes períodos analisados, extraindo seus impactos.

\section{RESULTADOS ESPERADOS}

Assim, os resultados esperados permeiam a oferta de um aprendizado sistematizado, mediante a análise de indicadores de desempenho, possibilitando a replicação às demais cadeias produtivas das câmaras setoriais do Mapa, bem como o compartilhamento com outras entidades públicas e privadas de interesse.

Dessa maneira, esta pesquisa permitirá o melhor entendimento da evoluçáo e do desenvolvimento das cadeias produtivas de cachaça, fibras naturais, ovinos e caprinos, algodão e aves e suínos desde o surgimento das câmaras setoriais. Além disso, nos possibilitará conhecer os pontos fortes e fracos de cada uma, as suas respectivas peculiaridades e as similaridades existentes, de forma que se favoreça a produção de políticas públicas e estratégias público-privadas derivadas ao setor. Tais produtos permitirão que essas cadeias se tornem mais competitivas e que sirvam de suporte para que não enfrentem ou mergulhem em crises.

Como resultados dos objetivos do estudo, serão realizados relatórios parcial e final. Será previsto, ainda, um seminário, em que seráo expostos os resultados em data e condiçóes a serem acordadas com o Ipea e o Mapa.

5. Indicadores de desempenho são elementos que podem ser entendidos como uma métrica usada para a mensuração da eficiência ou da eficácia de práticas ou ações especificas (Callado, Callado e Machado, 2007). 


\section{REFERÊNCIAS}

BRASIL. Lei Agrícola no 8171, de 17 de janeiro de 1991. Dispõe sobre a política agrícola. Diário Oficial da Uniấo, Brasília, 18 jan. 1991. Disponível em: <https://bit.ly/3ezudn8>. Acesso em: 16 jan. 2019.

. Ministério da Agricultura, Pecuária e Abastecimento. Câmaras setoriais. Brasília: Mapa, 2019. Disponível em: <https://bit.ly/3vRQtOO>. Acesso em: 20 fev. 2020.

CALLADO, A. A. C.; CALLADO, A. L. C.; MACHADO, M. A. V. Indicadores de desempenho operacional e econômico: um estudo exploratório no contexto do agronegócio. Revista de Negócios, v. 12, n. 1, p. 3-15, 2007.

DAVIS, J. A.; GOLDBERG, R. A. A concept of agribusiness. Boston: Harvard University Graduate School of Business Administration, 1957. p. 4-24.

FREITAS, T. R.; NETO, R. S.; SCALCO, P. R. Cadeias produtivas do agronegócio de Goiás. Goiânia: UFG, 2014. (Textos para Discussão, n. 40).

FIEP - FEDERAÇÃO DAS INDÚSTRIAS DO ESTADO DO PARANÁ. Desenvolvimento das cadeias produtivas: fortalecimento das cadeias produtivas. Fiepr.org, 2016. Disponível em: $<$ https://bit.ly/3o9djPa>. Acesso em: 20 fev. 2020

JANK. M. S.; ZERBINI, A. N.; CLEAVER, I. Competitividade internacional do agronegócio brasileiro, visão estratégica e políticas públicas. In: RODRIGUES, R. (Org.). Agro é paz: análises e propostas para o Brasil alimentar o mundo. Piracicaba: Esalq, 2018.

JÚNIOR, C. A. G. et al. Um estudo das deliberaçóes da Câmara Setorial do Açúcar e do Álcool, usando análise de correspondência. Revista de Economia e Sociologia Rural, v. 47, n. 1, p. 183-210, 2009.

SANTOS, L. G. et al. Central de cooperativas na comercialização de produtos da agricultura familiar: o caso da Centrafes do estado de Sergipe, Brasil. Otra Economía, v. 12, n. 22, p. 22-41, 2019.

SCHMIDT, N. S.; SILVA, C. L. Pesquisa e desenvolvimento na cadeia produtiva de frangos de corte no Brasil. Revista de Economia e Sociologia Rural, v. 56, n. 3, p. 467-482, 2018.

TAKAGI, M. Câmaras setoriais agroindustriais, representaçáo de interesses e políticas públicas. 2000. Dissertação (Mestrado) - Universidade Estadual de Campinas, Campinas, 2000.

TEIXEIRA, F. O. et al. Crescimento econômico dos estados brasileiros através da sofisticação de suas exportaçôes agropecuárias (2002-2014). Revista de Desenvolvimento Econômico, v. 1, n. 39, 2018. 


\title{
O APOIO À CONSTRUÇÃO DA POLÍTICA NACIONAL DE DESENVOLVIMENTO URBANO'
}

\author{
Marco Aurélio Costa ${ }^{2}$ \\ Lizandro Lui ${ }^{3}$
}

Em dezembro de 2019, a Secretaria Nacional de Desenvolvimento Regional e Urbano (SDRU), do Ministério do Desenvolvimento Regional (MDR), e o Ipea assinaram um termo de execução descentralizada (TED), visando ao estabelecimento de uma parceria institucional voltada para apoiar o processo de construção da Política Nacional de Desenvolvimento Urbano (PNDU).

O MDR tem, desde 2019, o mandato de algumas das principais politicas espaciais, na esfera do governo federal, acolhendo atribuiçóes que antes se encontravam compartilhadas entre os antigos ministérios das Cidades e da Integração, de modo que está sob sua responsabilidade a execução da Política Nacional de Ordenamento Territorial (PNOT), da Política Nacional de Irrigação, da Política Nacional de Desenvolvimento Regional (PNDR) e da formulação da própria PNDU.

O Ipea vem desenvolvendo, há alguns anos, por meio de diferentes iniciativas, um robusto trabalho de colaboração técnica voltado para a implementação e o acompanhamento da PNDR. Em um aprofundamento das relaçóes de parceria institucional que envolvem o MDR e o Ipea, mais precisamente a Dirur, compreendendo a importância de buscar uma articulaçáo entre PNOT, PNDR e PNDU, o MDR propôs o estabelecimento de uma nova parceria, envolvendo, desta vez, a Coordenaçáo de Estudos em Desenvolvimento Urbano (Codur), visando ao apoio à construção da PNDU.

$\mathrm{Na}$ justificativa para o TED que viria a ser firmado em dezembro, ${ }^{4}$ o MDR sublinha que as políticas territoriais são complementares, ainda que partam de escopos e escalas diferentes, sendo fundamental sua articulação.

1. DOI: http://dx.doi.org/10.38116/brua24art19

2. Técnico de planejamento e pesquisa e coordenador de Estudos em Desenvolvimento Urbano na Diretoria de Estudos e Políticas Regionais, Urbanas e Ambientais (Dirur) do Ipea; coordenador nacional do Instituto Nacional em Ciência e Tecnologia em Política Pública e Desenvolvimento Territorial (INPuT); e doutor em planejamento urbano e regional. E-mail:<marco.costa@ipea.gov.br>.

3. Pesquisador do Programa de Pesquisa para o Desenvolvimento Nacional (PNPD) na coordenação de Estudos em Desenvolvimento Urbano da Dirur/lpea. E-mail: <lizandro.lui@ipea.gov.br>.

4. TED oㅜ 71/2019, assinado pela então secretária nacional de desenvolvimento regional e urbano, em 9 de dezembro de 2019, e pelo presidente do Ipea, em 13 de dezembro. 
Ao contrário da PNDR, que já conta com uma versão atualizada, instituída por meio do Decreto no 9.810 , de 30 de maio de 2019, o desenvolvimento urbano ainda náo conta com uma política formalmente estruturada na esfera federal.

É bem verdade que, do ponto de vista jurídico-normativo, o Estatuto da Cidade (EC), Lei Federal no 10.257, de junho de 2001, estabeleceu as diretrizes gerais da política urbana no país. O EC tem sido observado, sobretudo pelos governos municipais, no tocante às atribuiçóes que foram conferidas a seus gestores. Contudo, do ponto de vista da estruturaçáo de uma política nacional, há ainda um percurso a ser vencido, no qual seja mais bem explicitado o papel da Uniáo para o desenvolvimento urbano, em suas relaçóes com os demais níveis da Federação, com vistas à construção de um marco de cooperação que contribua para a efetividade das diretrizes gerais da política urbana.

O desafio em tela trata-se, pois, da construção da PNDU, para a qual o Ipea colaborará por meio da produçáo de um conjunto de notas técnicas e documentos executivos, além de eventos de articulação técnica e institucional.

No TED original, de dezembro de 2019, duas são as principais etapas que envolvem maior engajamento por parte do Ipea: a produção de elementos que permitam pensar na agenda urbana, em suas diferentes e complementares escalas, no que se denominou de novo pacto urbano brasileiro; e a organização de uma reflexáo sobre o desafiador tema do financiamento do desenvolvimento urbano.

No que diz respeito à agenda urbana, já foi apresentada ao MDR uma primeira nota técnica conceitual abordando a contextualização do atual processo de construção da PNDU. Essa primeira nota técnica, exposta e discutida com a equipe da Coordenação-Geral de Apoio à Gestão Regional e Urbana (CGAGRU), está em processo final de revisão e será disponibilizada brevemente.

A nota apresenta o percurso da política urbana no país, tendo como referência os marcos legais relativos à política, em especial após a Constituição Federal de 1988 (CF/1988), abordando a questáo territorial no contexto do federalismo brasileiro, explorando as iniciativas associadas à efetivaçáo do direito à cidade e trazendo, ainda, propostas de agendas transversais que informam, qualificam e contextualizam os (novos) desafios colocados para a política urbana no país.

A partir dessa nota, estão sendo elaboradas mais quatro notas técnicas que debatem a agenda urbana brasileira, abarcando as escalas municipal, supramunicipal e regional e a questão das relaçôes interfederativas.

Quanto ao financiamento do desenvolvimento urbano, uma versão preliminar de uma primeira nota técnica, tratando da questão fiscal e extrafiscal, já foi entregue ao MDR. Outras notas abarcando as transferências intergovernamentais, o acesso a recursos onerosos e não onerosos e também a questão das parcerias entre os setores público e privado para o financiamento do desenvolvimento urbano estão sendo elaboradas, estando inseridas na versão original do TED.

Em maio de 2020, visando ampliar ainda mais a articulação entre Codur/Dirur/Ipea e CGAGRU/SNMAU 5 /MDR, o Aditivo ao TED no 71/2019 foi assinado, aumentando os

5. Secretaria Nacional de Mobilidade e Desenvolvimento Regional e Urbano. 
recursos transferidos para o Ipea e alargando o prazo para a realização das açôes acordadas entre as partes.

Com o aditivo, será possível ampliar o campo temático dos estudos que subsidiarão o processo de construção da PNDU. Isso inclui temas de agendas transversais (equidade social e viés intergeracional, segurança pública, meio ambiente, transformação digital e desenvolvimento econômico) e outros ligados à participação de segmentos sociais no processo de elaboração da PNDU, com vistas à construção de uma governança multinível.

Com efeito, as notas técnicas que estáo sendo desenvolvidas pela equipe da Codur têm como objetivo aprofundar o debate sobre a questão urbana no Brasil. Seja tratando dos temas diretamente associados à nova agenda urbana, dos temas transversais, da questáo do financiamento ou das discussóes em torno do federalismo brasileiro, espera-se que a contribuição técnica da equipe envolvida possa subsidiar o MDR e permitir que, nos próximos meses, esteja formulada uma primeira proposta de uma PNDU capaz de contribuir para o enfrentamento de velhas e novas questóes que desafiam as cidades brasileiras e demandam a atenção e a atuação do poder público, inclusive da Uniáo.

Por fim, ressalta-se o importante papel desempenhado pelo Ipea enquanto órgão que busca qualificar o debate em torno da formulação das políticas públicas - em especial das políticas de desenvolvimento urbano. Ao longo dos últimos anos, contribuímos para a construção do conhecimento relativo ao desenvolvimento urbano no país, tanto pela construção da plataforma Governança Metropolitana, desenvolvida no âmbito da Codur, quanto pela produção de livros, artigos, notas técnicas etc. Sendo assim, novamente, a instituição reforça a sua importância para a construção das políticas e para o desenvolvimento do país. 



\section{CONCESSÕES E PARCERIAS PÚBLICO-PRIVADAS NO DESENVOLVIMENTO URBANO ${ }^{1}$}

Jean Marlo Pepino de Paula²

\section{INTRODUÇÃO}

Esta nota de pesquisa apresenta reflexôes iniciais no contexto da formulação da Política Nacional de Desenvolvimento Urbano (PNDU). O Ipea firmou um acordo de cooperação com a Secretaria Nacional de Desenvolvimento Regional e Urbano (SDRU), do Ministério do Desenvolvimento Regional (MDR), para subsidiar a elaboração do respectivo plano. O desenvolvimento urbano está sendo enfrentado pelo governo federal com um duplo enfoque da construção social e interfaces com sua dimensão operacional, explorando uma noção ativa, para a qual convergem reflexôes e agendas diversas, que variam nos contextos socioespaciais e temporais.

Esses termos indicam a multiplicidade de aspectos e escalas que caracterizam a organicidade do desenvolvimento urbano e exacerbam a interdependência entre serviços variados, cada vez mais dissociados do poder público. Nesse contexto, a PNDU se apresenta como um instrumento do tipo guarda-chuva, elaborado para promover a harmonia entre disciplinas e entes da Federação e estimular habilidades e o aprimoramento contínuo, circunscrevendo as competências da Uniáo a serem operacionalizadas para tanto.

Apesar dessa diversidade, as discussóes iniciais entre o Ipea e a SDRU/MDR apontaram para quatro dimensóes do desenvolvimento urbano a partir de iniciativas internacionais como os Objetivos do Desenvolvimento Sustentável (ODS) e a Nova Agenda Urbana (NAU).

- Dimensão social: atinente à inclusão, segurança, resiliência e sustentabilidade.

- Dimensão econômica: referente aos padróes de produção e consumo.

- Dimensão ambiental: envolve os desafios climáticos.

- Dimensão político-institucional: trata do relacionamento com a sociedade e da organização e gestão de recursos e iniciativas.

Ainda que o desenvolvimento urbano seja tratado por meio de dimensôes relevantes, a interdependência entre elas é inevitável. Um exemplo disso é a atuação institucional para promover uma conscientizaçáo social sobre o ciclo de vida de produtos, padróes de consumo

1. DOI: http://dx.doi.org/10.38116/brua24art20

2. Técnico de planejamento e pesquisa na Diretoria de Estudos e Políticas Regionais, Urbanas e Ambientais (Dirur) do Ipea. 
e seus impactos ambientais, econômicos e sociais, valendo-se do sucesso dessas dimensôes para retroalimentar sua legitimidade e utilidade.

Essas causalidades e o fluxo de benefícios ainda são pouco discutidos no país e possuem elevado teor teórico e subjetivo, carecendo de evidências consistentes para qualificar os processos decisórios e legitimar políticas públicas. São lacunas como a baixa expressividade dos impactos promovidos pela melhoria da mobilidade ou do saneamento na saúde e na educaçáo, ou ainda a crescente dependência de iniciativas como essas de fontes ininterruptas de energia e comunicação. A fragilidade, a inexistência ou a abstração dessa visão orgânica resulta em políticas isoladas e míopes em sistemas sobrecarregados, os quais se esforçam para sobreviver à custa de fontes de recursos imediatos, aplicados de forma indiscriminada.

Em muitos casos, o vulto e a complexidade das intervençôes são incompatíveis com as capacidades locais disponíveis. Exigem conhecimentos e habilidades específicas e temporárias que podem ser complementadas por uma rede de parcerias com universidades, municípios limítrofes, esferas administrativas e empresas privadas. Essas redes são fortalecidas por normativas e arcabouços legais comuns em busca de um ambiente seguro, bem como compartilham conhecimento, habilidades e tecnologias.

Ocorre, em relação a seus insumos, da mesma forma - eles são frequentemente indisponíveis ou insuficientes. Assim, em meio ao esforço para lidar com a diversidade que envolve o desenvolvimento urbano, o financiamento tem se mostrado uma restrição comum a todas as iniciativas, independentemente da relevância da disciplina. Por isso, modelos de negócios estão sendo estruturados para complementar requisitos, alinhar objetivos e atrair parceiros por meio do compartilhamento de responsabilidades e da entrega de benefícios mútuos.

\section{SURGIMENTO E APLICAÇÃO DAS PARCERIAS NAS POLÍTICAS PÚBLICAS}

Almeida ${ }^{3}$ relata que o termo parceria público-privada (PPP) foi cunhado no final da década de 1960 para tratar da ausência dessas colaboraçôes nas organizaçóes multilaterais, limitando-se a poucas interaçóes entre doadores e governos nacionais. Para o autor, após a crise econômica internacional na década de 1970, organismos financeiros internacionais avançaram com a proposta, supervalorizando o mercado e perspectivas empresariais, ao mesmo tempo que desqualificavam o papel do Estado e a natureza pública de alguns bens. Dessa maneira, as urgentes reformas subsequentes naturalmente militariam pela redução e incompetência do Estado e pela promoção de capacidades adicionais conjuntas por meio de parcerias empresariais e da sociedade civil, encorajando tanto o apoio técnico como o financeiro.

Para Almeida, ${ }^{4}$ o termo PPP é utilizado pela literatura de modo amplo e dissensual em um plano no qual surgem questionamentos sobre a natureza dos atores, o objeto das parcerias e a alocação de atribuiçóes. Segundo o autor, a restrição das parcerias a atores privados lucrativos não é clara nem justificada, motivo pelo qual deve incluir organizaçôes sem fins lucrativos. A decisão em resolver "problemas coletivos" não necessariamente se refere à provisão de bens públicos, enquanto a desejada partilha de atribuiçóes é questionável, uma

3. Almeida, C. Parcerias público-privadas (PPP) no setor saúde: processos globais e dinâmicas nacionais. Cadernos de Saúde Pública, v. 33, p. e00197316, 2017.

4. Almeida, C. Parcerias público-privadas (PPP) no setor saúde: processos globais e dinâmicas nacionais. Cadernos de Saúde Pública, v. 33, p. e00197316, 2017. 
vez que são definidas unilateralmente e são impositivas - restando ao contratante aceitar ou não tais atribuiçôes.

Firmino ${ }^{5}$ também registra que as PPPs assumem diversos significados e práticas em meio a uma forte expansão no cenário internacional. Entre eles, a autora destaca seu longo prazo de duração, um modelo alternativo de governança e uma nova linguagem para dissimular as intençôes de privatização. A estudiosa propôe uma caracterização mais ampla das PPPs: delimitação compulsória de responsabilidades, riscos e benefícios; custo de transaçáo marcado por incertezas e especificidades; e potencial desequilíbrio de benefícios causado pela assimetria de informaçóes, inibido por processos de contratação e dispositivos contratuais, como a distribuição de riscos e a remuneração por desempenho.

A alocação de atribuiçôes reforça papéis e consequentes capacidades de contratados e contratantes, refletindo o termo parceria como uma associação que visa à troca mútua de benefícios, uma "via de duas mãos". Depende da adequada sinergia entre dois ou mais interessados, sendo esperado que a respectiva legislação estabeleça atribuiçôes para cada envolvido de forma a mitigar e melhor distribuir riscos por meio de uma composição adequada de competências e responsabilidades. Assim, diante de um cenário favorável ao avanço das PPPs, vislumbra-se que o setor público avance para uma perspectiva mais estratégica, tratando-as de forma mais ampla, reconhecendo peculiaridades e fomentando um ambiente positivo à sua proliferação e sustentabilidade.

Para tanto, no que se refere aos subsídios às PPPs na PNDU, propôe-se uma caracterização das empresas licitantes e contratadas, dos entes públicos e do desenvolvimento do conhecimento pelas universidades nacionais. Pretende-se, além de estimular uma perspectiva mais orgânica com informaçóes sobre os setores públicos, privados e a academia, desenhar o citado ambiente positivo por meio de mapas de rede, avançando em direção a um esforço para qualificar os processos decisórios com impactos mais complexos e abstratos.

5. Firmino, S. I. Fatores críticos de sucesso das parcerias público-privadas: aspectos político-institucionais. Estudo de caso das rodovias em Portugal. Revista de Administração Pública, v. 52, n. 6, p. 1270-1281, 2018. 

INDICADORES 



\section{INDICADORES URBANOS E METROPOLITANOS}

\section{1 ÍNDICE E SUBÍNDICES DE VULNERABILIDADE SOCIAL (2017-2018)}

A tabela 1 traz os dados relativos ao Índice de Vulnerabilidade Social (IVS) para as 27 Unidades da Federação (UFs) e para o país em 2017 e 2018, atualizando o acervo de indicadores publicados no Boletim Regional Urbano e Ambiental (Brua).

TABELA 1

Brasil: evolução do IVS para as UFs e o país (2017-2018)

\begin{tabular}{|c|c|c|}
\hline \multirow{2}{*}{ Região } & \multicolumn{2}{|c|}{ IVS } \\
\hline & 2017 & 2018 \\
\hline Brasil & 0,243 & 0,240 \\
\hline Distrito Federal & 0,258 & 0,251 \\
\hline Goiás & 0,247 & 0,234 \\
\hline Mato Grosso & 0,227 & 0,225 \\
\hline Mato Grosso do Sul & 0,194 & 0,192 \\
\hline Alagoas & 0,338 & 0,330 \\
\hline Bahia & 0,298 & 0,290 \\
\hline Ceará & 0,272 & 0,262 \\
\hline Maranhão & 0,349 & 0,349 \\
\hline Paraíba & 0,292 & 0,302 \\
\hline Pernambuco & 0,336 & 0,323 \\
\hline Piauí & 0,279 & 0,276 \\
\hline Rio Grande do Norte & 0,283 & 0,273 \\
\hline Sergipe & 0,298 & 0,306 \\
\hline Acre & 0,374 & 0,349 \\
\hline Amapá & 0,253 & 0,241 \\
\hline Amazonas & 0,327 & 0,330 \\
\hline Pará & 0,278 & 0,284 \\
\hline Rondônia & 0,191 & 0,199 \\
\hline Roraima & 0,232 & 0,256 \\
\hline Tocantins & 0,240 & 0,249 \\
\hline Espírito Santo & 0,227 & 0,216 \\
\hline Minas Gerais & 0,207 & 0,205 \\
\hline Rio de Janeiro & 0,284 & 0,278 \\
\hline São Paulo & 0,241 & 0,239 \\
\hline Paraná & 0,186 & 0,186 \\
\hline Rio Grande do Sul & 0,209 & 0,212 \\
\hline Santa Catarina & 0,134 & 0,129 \\
\hline
\end{tabular}

Fonte: Ipea, 2021.

1. DOI: http://dx.doi.org/10.38116/brua24art21 
É possível observar que, em 2018, os níveis mais elevados do IVS ainda se concentram na região Nordeste; entretanto, observou-se o aumento do índice na maioria das UFs da região Norte (Amazonas, Pará, Rondônia, Roraima e Tocantins), especialmente em Roraima, contrapondo-se à melhora observada no Acre, que, apesar disso, continua a ter o pior IVS do Brasil.

Os estados do Acre e do Maranhão apresentam os piores índices observados entre as UFs brasileiras (0,349), seguidos de Alagoas e Amazonas (0,330). O Maranhão manteve seu índice de 2017 e o Amazonas, que apresentou melhora em 2017, recuou ao patamar que havia sido observado em $2016 .^{2}$

Apesar de apresentar as UFs com os índices mais baixos, a regiăo Nordeste registrou melhora do IVS em seis estados. Apenas dois estados apresentaram piora no índice: Paraíba e Sergipe, os quais deixaram a faixa da baixa vulnerabilidade social para se situarem na faixa da média vulnerabilidade social.

$\mathrm{Na}$ tabela 2, que traz a análise para as dimensóes do IVS, é possível perceber que as regiôes Centro-Oeste, Sudeste e Sul detêm IVS Capital Humano (IVS-CH) e IVS Renda e Trabalho (IVS-RT) na faixa da baixa ou muito baixa vulnerabilidade social, ao passo que as regióes Norte e Nordeste concentram os maiores IVS-CH e IVS-RT.

TABELA 2

Brasil: evolução das dimensões do IVS para as UFs e para o país (2017-2018)

\begin{tabular}{|c|c|c|c|c|c|c|}
\hline \multirow{2}{*}{ Região } & \multicolumn{3}{|c|}{2017} & \multicolumn{3}{|c|}{2018} \\
\hline & IVS-IU & IVS-CH & IVS-RT & IVS-IU & IVS-CH & IVS-RT \\
\hline Brasil & 0,204 & 0,226 & 0,300 & 0,203 & 0,221 & 0,295 \\
\hline Distrito Federal & 0,405 & 0,171 & 0,198 & 0,403 & 0,152 & 0,198 \\
\hline Goiás & 0,270 & 0,218 & 0,253 & 0,269 & 0,205 & 0,228 \\
\hline Mato Grosso & 0,229 & 0,219 & 0,232 & 0,230 & 0,222 & 0,221 \\
\hline Mato Grosso do Sul & 0,134 & 0,209 & 0,239 & 0,136 & 0,219 & 0,220 \\
\hline Alagoas & 0,166 & 0,386 & 0,460 & 0,167 & 0,371 & 0,451 \\
\hline Bahia & 0,137 & 0,321 & 0,435 & 0,134 & 0,305 & 0,430 \\
\hline Ceará & 0,158 & 0,294 & 0,363 & 0,150 & 0,281 & 0,354 \\
\hline Maranhão & 0,272 & 0,336 & 0,440 & 0,256 & 0,335 & 0,456 \\
\hline Paraíba & 0,189 & 0,313 & 0,375 & 0,189 & 0,332 & 0,385 \\
\hline Pernambuco & 0,273 & 0,306 & 0,430 & 0,273 & 0,286 & 0,410 \\
\hline Piauí & 0,138 & 0,298 & 0,400 & 0,127 & 0,295 & 0,405 \\
\hline Rio Grande do Norte & 0,171 & 0,281 & 0,398 & 0,170 & 0,282 & 0,368 \\
\hline Sergipe & 0,142 & 0,321 & 0,431 & 0,144 & 0,315 & 0,458 \\
\hline Acre & 0,335 & 0,366 & 0,420 & 0,322 & 0,343 & 0,383 \\
\hline Amapá & 0,071 & 0,303 & 0,386 & 0,057 & 0,269 & 0,396 \\
\hline Amazonas & 0,318 & 0,283 & 0,379 & 0,320 & 0,294 & 0,374 \\
\hline Pará & 0,171 & 0,287 & 0,377 & 0,170 & 0,288 & 0,394 \\
\hline Rondônia & 0,058 & 0,260 & 0,254 & 0,057 & 0,257 & 0,283 \\
\hline Roraima & 0,197 & 0,231 & 0,269 & 0,197 & 0,259 & 0,311 \\
\hline Tocantins & 0,173 & 0,242 & 0,306 & 0,177 & 0,268 & 0,300 \\
\hline Espírito Santo & 0,183 & 0,217 & 0,280 & 0,185 & 0,197 & 0,264 \\
\hline Minas Gerais & 0,129 & 0,201 & 0,291 & 0,128 & 0,205 & 0,280 \\
\hline Rio de Janeiro & 0,407 & 0,173 & 0,271 & 0,406 & 0,165 & 0,263 \\
\hline São Paulo & 0,328 & 0,157 & 0,239 & 0,328 & 0,152 & 0,236 \\
\hline Paraná & 0,163 & 0,184 & 0,212 & 0,168 & 0,186 & 0,203 \\
\hline Rio Grande do Sul & 0,238 & 0,174 & 0,214 & 0,240 & 0,178 & 0,218 \\
\hline Santa Catarina & 0,098 & 0,149 & 0,156 & 0,098 & 0,142 & 0,146 \\
\hline
\end{tabular}

Fonte: Ipea, 2021.

2. Disponível em: <https://bit.ly/3fFNbaU>. 
Destacam-se os mais altos subíndices do país nas UFs de Alagoas, Maranhão e Sergipe, em 2018, e o aumento do IVS-CH, para o período 2017-2018, em Roraima e Tocantins, mantendo-os na faixa de baixa vulnerabilidade social associada ao capital humano.

Roraima também apresentou um aumento expressivo no IVS-RT, culminando, nesse caso, na mudança para a faixa de média vulnerabilidade social na dimensão de renda e trabalho.

Conforme se pode observar na tabela 2, o IVS Infraestrutura Urbana (IVS-IU) é a dimensão com maior desigualdade entre as UFs, em relação às suas Grandes Regiôes, apresentando o melhor desempenho geral.

O Amapá, que já apresentava o segundo IVS-IU mais baixo do país, evoluiu ainda mais e alcançou o IVS-IU de Rondônia. Apesar da melhora discreta do IVS-IU no Distrito Federal e no Rio de Janeiro, as duas UFs ainda possuem os maiores subíndices da categoria no país. O Amapá também apresentou a melhora mais expressiva do IVS-CH, seguido do Acre, que se destacou positivamente, reduzindo os subíndices de vulnerabilidade em cada uma das três dimensóes, apesar de ainda possuir altos IVS-UI e IVS-CH.

\section{DESAGREGAÇÕES DO IVS (2017-2018)}

As próximas tabelas trazem o IVS com os dados desagregados por sexo, cor e situação de domicílio selecionados: população feminina (tabela 3), brancos e negros (tabela 4) e para a população urbana (tabela 5).

$\mathrm{Na}$ tabela 3, que diz respeito à desagregação em relação à populaçáo feminina, observou-se uma pequena retração do índice em UFs que apresentam IVS mais elevados, a saber: Alagoas, Maranhão e Amazonas.

Em 2018, a melhora do IVS para as mulheres no Mato Grosso e na Bahia garantiu a evoluçáo de suas classificaçôes para as faixas de muito baixa e baixa vulnerabilidade social, respectivamente. Destaca-se, também, a evoluçáo do índice observado no Acre, ainda que sua classificação, em 2018, tenha se mantido na faixa de média vulnerabilidade social.

Ainda que a região Nordeste apresente os índices mais elevados também para o recorte da populaçáo feminina, a regiáo Norte foi a que mostrou o maior aumento do IVS no período. Vale dizer que a região reúne estados com IVS na faixa da média vulnerabilidade social (Acre e Amazonas), mas também traz o caso de Rondônia, onde o IVS está na faixa da muito baixa vulnerabilidade social e é um dos menores do país.

Ainda na regiáo Norte, fica o destaque negativo para Roraima, onde o aumento do IVS da população feminina fez com que a UF caísse uma faixa da vulnerabilidade social.

O IVS da população feminina mais baixo do país encontra-se em Santa Catarina $(0,127)$, e as UFs de Mato Grosso, Mato Grosso do Sul, Paraná e Rio Grande do Sul, além do estado de Rondônia, encontram-se na mesma faixa de muito baixa vulnerabilidade social. 
TABELA 3

Brasil: evolução do IVS das mulheres para as UFs e para o país (2017-2018)

\begin{tabular}{|c|c|c|}
\hline \multirow{2}{*}{ Região } & \multicolumn{2}{|c|}{ IVS } \\
\hline & 2017 & 2018 \\
\hline Brasil & 0,252 & 0,247 \\
\hline Distrito Federal & 0,269 & 0,258 \\
\hline Goiás & 0,273 & 0,263 \\
\hline Mato Grosso & 0,203 & 0,198 \\
\hline Mato Grosso do Sul & 0,196 & 0,194 \\
\hline Alagoas & 0,344 & 0,338 \\
\hline Bahia & 0,303 & 0,293 \\
\hline Ceará & 0,277 & 0,259 \\
\hline Maranhão & 0,334 & 0,331 \\
\hline Paraíba & 0,279 & 0,293 \\
\hline Pernambuco & 0,335 & 0,323 \\
\hline Piauí & 0,257 & 0,257 \\
\hline Rio Grande do Norte & 0,287 & 0,268 \\
\hline Sergipe & 0,300 & 0,311 \\
\hline Acre & 0,353 & 0,324 \\
\hline Amapá & 0,253 & 0,236 \\
\hline Amazonas & 0,331 & 0,328 \\
\hline Pará & 0,287 & 0,293 \\
\hline Rondônia & 0,178 & 0,189 \\
\hline Roraima & 0,198 & 0,226 \\
\hline Tocantins & 0,214 & 0,224 \\
\hline Espírito Santo & 0,260 & 0,245 \\
\hline Minas Gerais & 0,218 & 0,212 \\
\hline Rio de Janeiro & 0,295 & 0,291 \\
\hline São Paulo & 0,272 & 0,269 \\
\hline Paraná & 0,198 & 0,194 \\
\hline Rio Grande do Sul & 0,185 & 0,189 \\
\hline Santa Catarina & 0,133 & 0,127 \\
\hline
\end{tabular}

Fonte: Ipea, 2021.

A tabela 4, por seu turno, traz o IVS para a população autodeclarada branca ou preta nas UFs do país, permitindo apontar as oscilaçóes ocorridas entre 2017 e 2018, segundo os dados da Pesquisa Nacional por Amostra de Domicílios (PNAD), realizada pelo Instituto Brasileiro de Geografia e Estatística (IBGE). 
TABELA 4

Brasil: evolução do IVS para as UFs e para o país por cor (2017-2018)

\begin{tabular}{|c|c|c|c|c|}
\hline \multirow{2}{*}{ Região } & \multicolumn{2}{|c|}{ Brancos } & \multicolumn{2}{|c|}{ Negros } \\
\hline & 2017 & 2018 & 2017 & 2018 \\
\hline Brasil & 0,201 & 0,198 & 0,279 & 0,273 \\
\hline Distrito Federal & 0,226 & 0,230 & 0,278 & 0,265 \\
\hline Goiás & 0,195 & 0,189 & 0,269 & 0,251 \\
\hline Mato Grosso & 0,180 & 0,195 & 0,244 & 0,233 \\
\hline Mato Grosso do Sul & 0,137 & 0,142 & 0,222 & 0,214 \\
\hline Alagoas & 0,302 & 0,274 & 0,349 & 0,349 \\
\hline Bahia & 0,236 & 0,259 & 0,312 & 0,296 \\
\hline Ceará & 0,234 & 0,230 & 0,287 & 0,274 \\
\hline Maranhão & 0,313 & 0,299 & 0,358 & 0,361 \\
\hline Paraíba & 0,293 & 0,292 & 0,297 & 0,311 \\
\hline Pernambuco & 0,286 & 0,276 & 0,358 & 0,345 \\
\hline Piauí & 0,227 & 0,213 & 0,291 & 0,290 \\
\hline Rio Grande do Norte & 0,244 & 0,226 & 0,305 & 0,299 \\
\hline Sergipe & 0,248 & 0,269 & 0,310 & 0,315 \\
\hline Acre & 0,346 & 0,297 & 0,377 & 0,360 \\
\hline Amapá & 0,226 & 0,195 & 0,259 & 0,250 \\
\hline Amazonas & 0,245 & 0,229 & 0,344 & 0,350 \\
\hline Pará & 0,255 & 0,253 & 0,283 & 0,291 \\
\hline Rondônia & 0,186 & 0,181 & 0,195 & 0,208 \\
\hline Roraima & 0,250 & 0,275 & 0,228 & 0,251 \\
\hline Tocantins & 0,199 & 0,184 & 0,252 & 0,263 \\
\hline Espírito Santo & 0,185 & 0,180 & 0,252 & 0,236 \\
\hline Minas Gerais & 0,172 & 0,173 & 0,230 & 0,224 \\
\hline Rio de Janeiro & 0,244 & 0,242 & 0,310 & 0,303 \\
\hline São Paulo & 0,215 & 0,210 & 0,278 & 0,277 \\
\hline Paraná & 0,176 & 0,173 & 0,215 & 0,216 \\
\hline Rio Grande do Sul & 0,184 & 0,188 & 0,274 & 0,273 \\
\hline Santa Catarina & 0,118 & 0,116 & 0,196 & 0,171 \\
\hline
\end{tabular}

Fonte: Ipea, 2021.

Em nível nacional, a classificação da população branca em termos das faixas do IVS permitiu uma mudança de faixa, passando o índice para a faixa da muito baixa vulnerabilidade social. O IVS da populaçáo negra, embora tenha permanecido na mesma faixa de 2017 , registrou uma reduçấo mais intensa.

$\mathrm{Na}$ análise dos dados por UF, ainda que tenhamos observado uma mudança muito positiva nos índices para a população autodeclarada branca nos estados de Acre, Amapá, Alagoas e Maranhão, repercutindo na conquista de classificaçóes melhores no IVS, três grandes aumentos foram observados na Bahia, no Sergipe e em Roraima.

A melhora do índice mais expressiva para a população autodeclarada negra ocorreu em Santa Catarina, estado seguido por Goiás, Acre, Bahia e Espírito Santo. Na Bahia e no Rio Grande do Norte, as classificaçôes evoluíram de média para baixa vulnerabilidade social; em contrapartida, nas UFs de Paraíba e Rondônia, as classificaçóes foram de baixa para média e muito baixa para baixa, respectivamente. 
Comparando os dois grupos e destacando a desigualdade existente entre eles, Roraima é a única UF em que o IVS para a população branca supera o IVS da população negra. Nessa UF, o IVS aumentou, entre 2017 e 2018, para as duas populaçóes.

O Amazonas segue em disparado como a UF mais desigual do país, tendo evidenciado ainda mais essa discrepância, seguido pelo Rio Grande do Sul, embora este tenha reduzido levemente a diferença entre os grupos no que se refere ao IVS.

Seguindo as análises com dados desagregados, a tabela 5 traz os dados do IVS para a população urbana. É possível observar que o Nordeste apresentou melhora do índice na maioria das UFs, sobretudo em Pernambuco e Rio Grande do Norte, tendo piorado apenas na Paraíba e em Sergipe, que, como vimos anteriormente, foram os dois estados que apresentaram aumento do IVS. Apesar dos avanços registrados na maioria de seus estados, a região ainda concentra os maiores IVS para a categoria urbana no país.

TABELA 5

Brasil: evolução do IVS da população urbana para as UFs e para o país (2017-2018)

\begin{tabular}{|c|c|c|}
\hline \multirow{2}{*}{ Região } & \multicolumn{2}{|c|}{ IVS } \\
\hline & 2017 & 2018 \\
\hline Brasil & 0,232 & 0,228 \\
\hline Distrito Federal & 0,255 & 0,249 \\
\hline Goiás & 0,244 & 0,233 \\
\hline Mato Grosso & 0,216 & 0,211 \\
\hline Mato Grosso do Sul & 0,195 & 0,193 \\
\hline Alagoas & 0,306 & 0,294 \\
\hline Bahia & 0,265 & 0,252 \\
\hline Ceará & 0,258 & 0,251 \\
\hline Maranhão & 0,305 & 0,304 \\
\hline Paraíba & 0,267 & 0,277 \\
\hline Pernambuco & 0,318 & 0,303 \\
\hline Piauí & 0,234 & 0,231 \\
\hline Rio Grande do Norte & 0,256 & 0,239 \\
\hline Sergipe & 0,255 & 0,268 \\
\hline Acre & 0,315 & 0,303 \\
\hline Amapá & 0,244 & 0,233 \\
\hline Amazonas & 0,324 & 0,328 \\
\hline Pará & 0,248 & 0,251 \\
\hline Rondônia & 0,171 & 0,182 \\
\hline Roraima & 0,201 & 0,213 \\
\hline Tocantins & 0,223 & 0,234 \\
\hline Espírito Santo & 0,232 & 0,220 \\
\hline Minas Gerais & 0,192 & 0,190 \\
\hline Rio de Janeiro & 0,282 & 0,276 \\
\hline São Paulo & 0,244 & 0,241 \\
\hline Paraná & 0,178 & 0,176 \\
\hline Rio Grande do Sul & 0,199 & 0,202 \\
\hline Santa Catarina & 0,122 & 0,116 \\
\hline
\end{tabular}

Fonte: Ipea, 2021. 
Na região Norte, apesar de os índices serem melhores que os observados para o Nordeste, houve aumento no IVS em cinco UFs, com melhora apenas para o Acre e o Amapá.

Com exceção do Amazonas (primeiro), que sofreu com o aumento de seu IVS na categoria, e Maranhão (segundo), com uma redução tímida, as demais UFs que compunham o ranking de maiores índices - Pernambuco (terceiro), Acre (terceiro) e Alagoas (quinto) apresentaram evoluçôes em seus índices, tendo a UF de Alagoas ascendido a sua classificação da faixa da média para a faixa da baixa vulnerabilidade social no meio urbano.

Santa Catarina segue apresentando o menor IVS urbano do país, tendo melhorado o índice entre 2017 e 2018. Além de Santa Catarina, Mato Grosso do Sul, Rondônia, Minas Gerais e Paraná também se situam na faixa da muito baixa vulnerabilidade social para suas populaçôes urbanas, configurando as melhores situaçóes observadas no país. 



\section{INDICADOR REGIONAL}

\section{EVOLUÇÃO DOS FINANCIAMENTOS CONCEDIDOS PELO PRONAF NAS REGIÕES BRASILEIRAS NO PERÍODO 2000-2020}

O Programa Nacional de Fortalecimento da Agricultura Familiar (Pronaf) foi oficialmente instituído em 1996 pelo Decreto no 1.946, com o objetivo de promover o desenvolvimento sustentável daquele segmento e visando ao aumento da capacidade produtiva, à geraçáo de empregos e à melhoria da renda. Para ter acesso aos créditos do programa, os agricultores devem atender a alguns requisitos relacionados ao tamanho máximo da área do estabelecimento rural, à obtenção de um percentual mínimo de renda oriunda de atividades realizadas nesse local e à utilização exclusiva de mão de obra e gerenciamento familiares. Em 2020, os empréstimos concedidos pelo Pronaf corresponderam a $\mathrm{R} \$ 31,3$ bilhóes, totalizando 1,4 milháo de contratos em vigor.

A tabela 1 apresenta a evolução dos valores dos empréstimos concedidos pelo Pronaf em termos totais (Brasil) e quanto à sua distribuição entre as cinco regiốes geográficas, assim como as suas principais fontes de financiamento, para os anos de 2000 a 2020.

O montante total de recursos apresentou um crescimento superior a $400 \%$ em termos reais ao longo do período, passando de $\mathrm{R}$ \$ 6,1 bilhôes para $\mathrm{R}$ \$ 31,3 bilhôes (ambos em valores de 2020).

O maior percentual dos financiamentos se concentrou na regiáo Sul, com média anual de $52 \%$ do montante total (Brasil). As demais regióes apresentaram participaçóes menores, com médias anuais de $19 \%$ no Sudeste, $15 \%$ no Nordeste, $7,5 \%$ no Centro-Oeste e 6,5\% no Norte. As regiôes Nordeste e Norte, contudo, exibiram as maiores taxas de crescimento no volume de financiamentos concedidos no período, superiores a $500 \%$ em termos reais.

Quanto às principais fontes de financiamento, observam-se comportamentos similares em todas as regióes. Os recursos equalizáveis do Resultado do Tesouro Nacional (RTN), que financiaram uma parte significante dos empréstimos do Pronaf durante a década de 2000 a 2010, tiveram sua participação bastante reduzida nos anos mais recentes. O mesmo pode ser dito com relação aos recursos provenientes do Fundo de Amparo ao Trabalhador (FAT), que passou de principal fonte de financiamento naquela década para valores nulos nos últimos anos. Em contrapartida, entre 2010 e 2020, observou-se um crescimento expressivo dos financiamentos concedidos pela poupança rural (principalmente nas regióes Norte e Centro-Oeste), assim como dos empréstimos com os recursos obrigatórios denominados de Manual de Crédito Rural (MCR) 6.2. Cabe também destacar participaçóes um pouco menos

1. DOI: http://dx.doi.org/10.38116/brua24art22 
expressivas, mas também importantes, dos recursos provenientes do BNDES ${ }^{2}$ Finame $^{3}$ e do Instrumento Híbrido de Capital e Dívida (IHCD) a partir de 2012.

Por fim, as participaçôes dos fundos constitucionais de financiamento como fontes de recursos do Pronaf também se mostraram importantes em suas respectivas regiões. O Fundo Constitucional de Financiamento do Nordeste (FNE) representou uma das principais fontes na região, além de contribuir na região Sudeste com recursos destinados aos municípios de Minas Gerais e Espírito Santo, que fazem parte do Semiárido. Da mesma maneira, o Fundo Constitucional de Financiamento do Centro-Oeste (FCO) e o Fundo Constitucional de Financiamento do Norte (FNO) estiveram entre as maiores formas de financiamento do Centro-Oeste e do Norte em boa parte do período, sendo superados apenas pela poupança rural nos anos mais recentes.

2. Banco Nacional de Desenvolvimento Econômico e Social.

3. Agência Especial de Financiamento Industrial. 


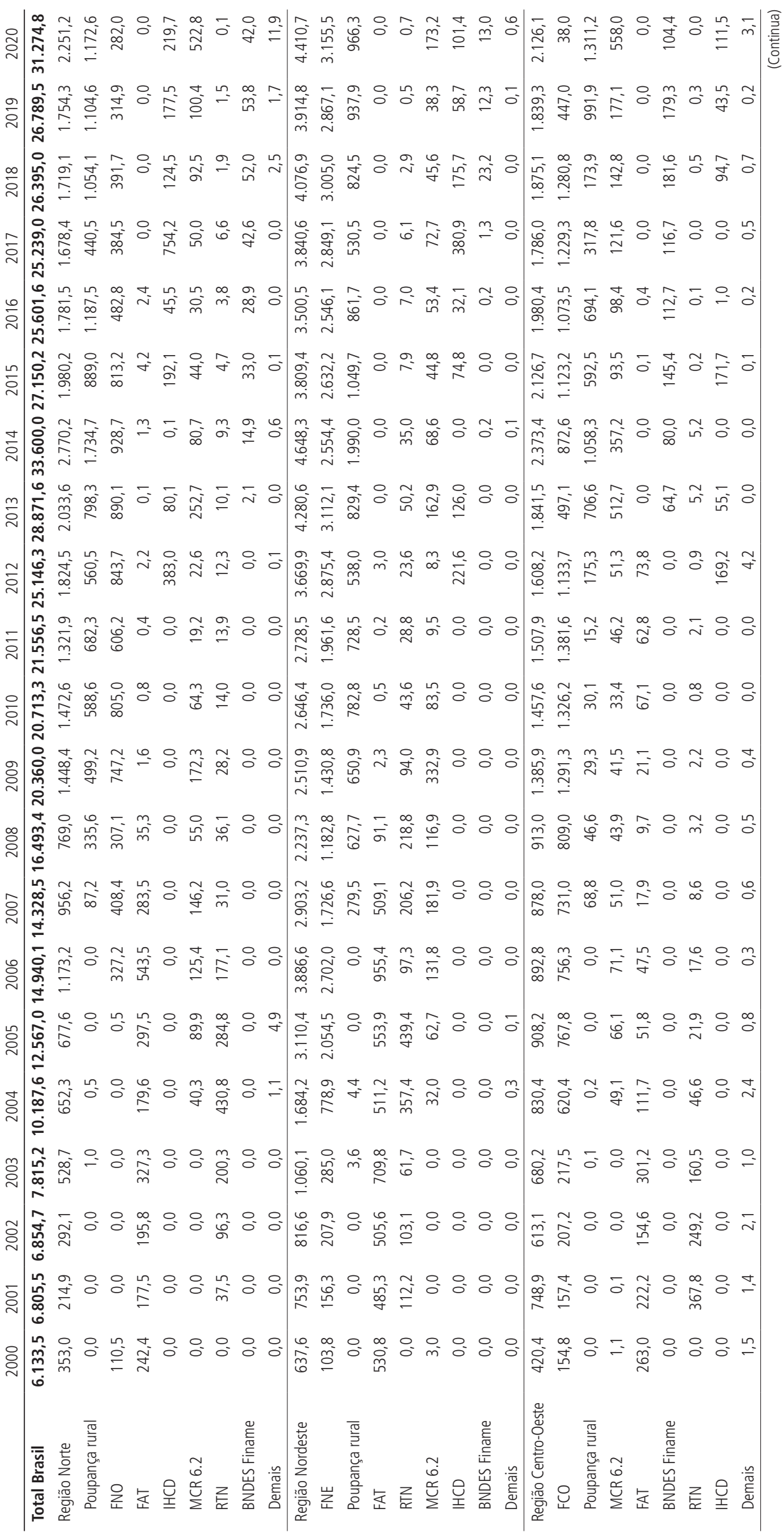




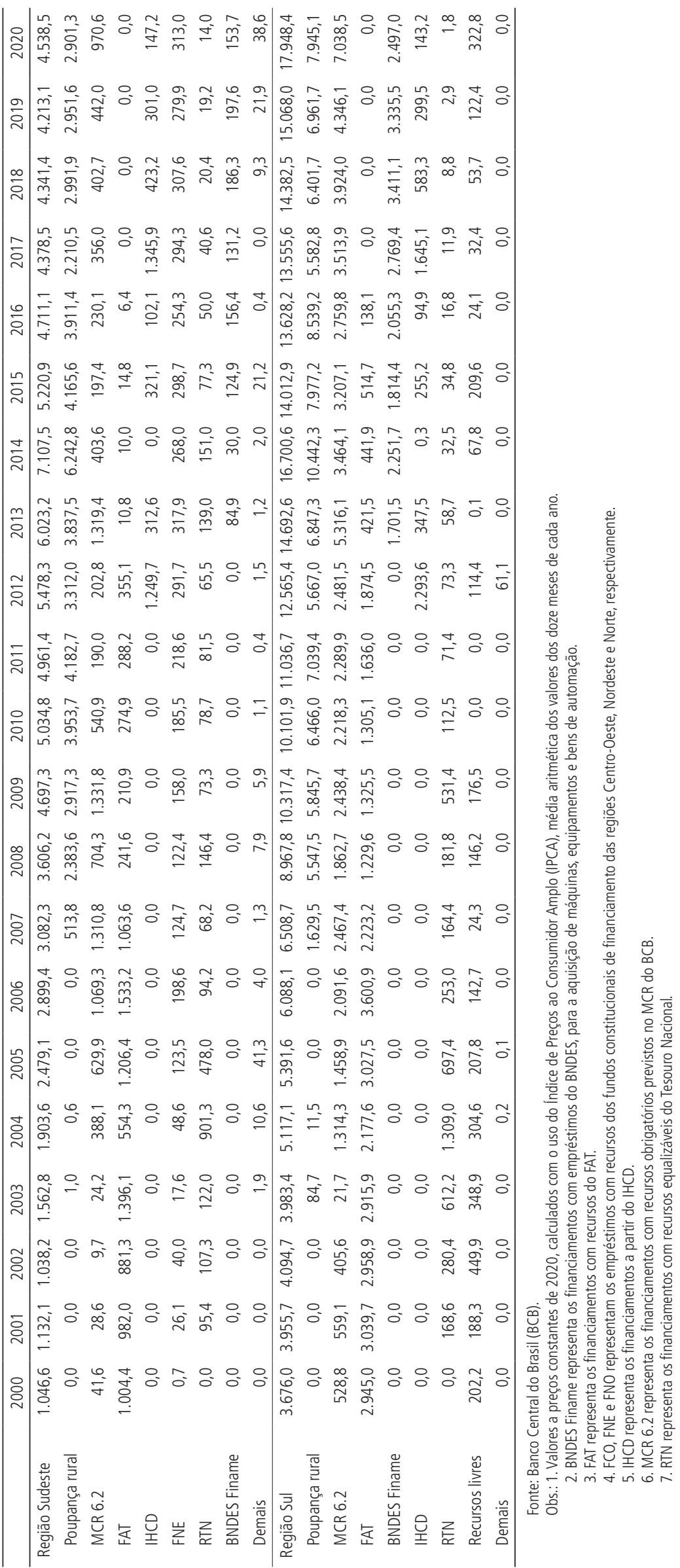




\section{INDICADORES AMBIENTAIS ${ }^{1}$}

\section{DENSIDADE DE FOCOS DE CALOR POR MUNICÍPIO (NÚMERO/HECTARE)}

O Instituto Nacional de Pesquisas Espaciais (Inpe) gera rotineiramente o número de focos de calor, em diferentes níveis de espacialização, para todo o país. Diversos sensores são utilizados nessa tarefa. $\mathrm{O}$ indicador adotado por este texto utiliza os registros de focos de calor do satélite Aqua (sensor Moderate Resolution Imaging Spectroradiometer - Modis), que corresponde ao satélite de referência adotado pelo Inpe, ou seja, aquele que é utilizado para comparaçôes temporais no trabalho de monitoramento realizado pela instituição. Os registros de focos de calor correspondem às informaçóes geradas no período da manhã e da tarde - passagem das 4h Greenwich Mean Time ${ }^{2}$ (GMT) e das 17h GMT, respectivamente -, e são apresentados na base de dados do Inpe como Aqua M-T. Os focos de calor permitem identificar as áreas do país onde estáo acontecendo mudanças importantes no uso do solo.

O quantitativo de focos de calor no Brasil alcançou 197.632 em 2019, um aumento de 48,7\% em relação ao ano anterior. Tal aumento acarretou um incremento generalizado na densidade de focos por município (mapa 1), com destaque para o noroeste de Rondônia.

TABELA 1

Brasil: total de focos por ano

\begin{tabular}{lc}
\hline & Quantidade \\
\hline 2012 & 217.238 \\
2013 & 128.149 \\
2014 & 175.900 \\
2015 & 216.782 \\
2016 & 184.218 \\
2017 & 207.511 \\
2018 & 132.872 \\
2019 & 197.632 \\
\hline
\end{tabular}

Fonte: Inpe.

Além disso, nos municípios localizados no centro e no sul do Maranhão, no Tocantins, no oeste do Piauí e na Bahia também houve importante aumento nas densidades em comparaçâo

1. DOI: http://dx.doi.org/10.38116/brua24art23

2. Tempo Médio de Greenwich. 
com o ano anterior. As áreas constituídas por esses quatro estados, região conhecida como Matopiba, correspondem à última fronteira agrícola dos Cerrados brasileiros, e têm sido alvo de forte expansão do agronegócio, em particular da cultura da soja. Destaca-se, ainda, aumento na densidade de focos de calor em municípios da regiáo central e do leste do Piauí, no bioma Caatinga. Finalmente, cabe mencionar também os incrementos registrados em municípios de Mato Grosso, em especial no leste do estado, bem como na região pantaneira, com destaque para Corumbá e municípios adjacentes, em Mato Grosso do Sul.

MAPA 1

Brasil: densidades municipais de focos de calor (2012-2019)

1 A - Densidade de focos de calor (2019)

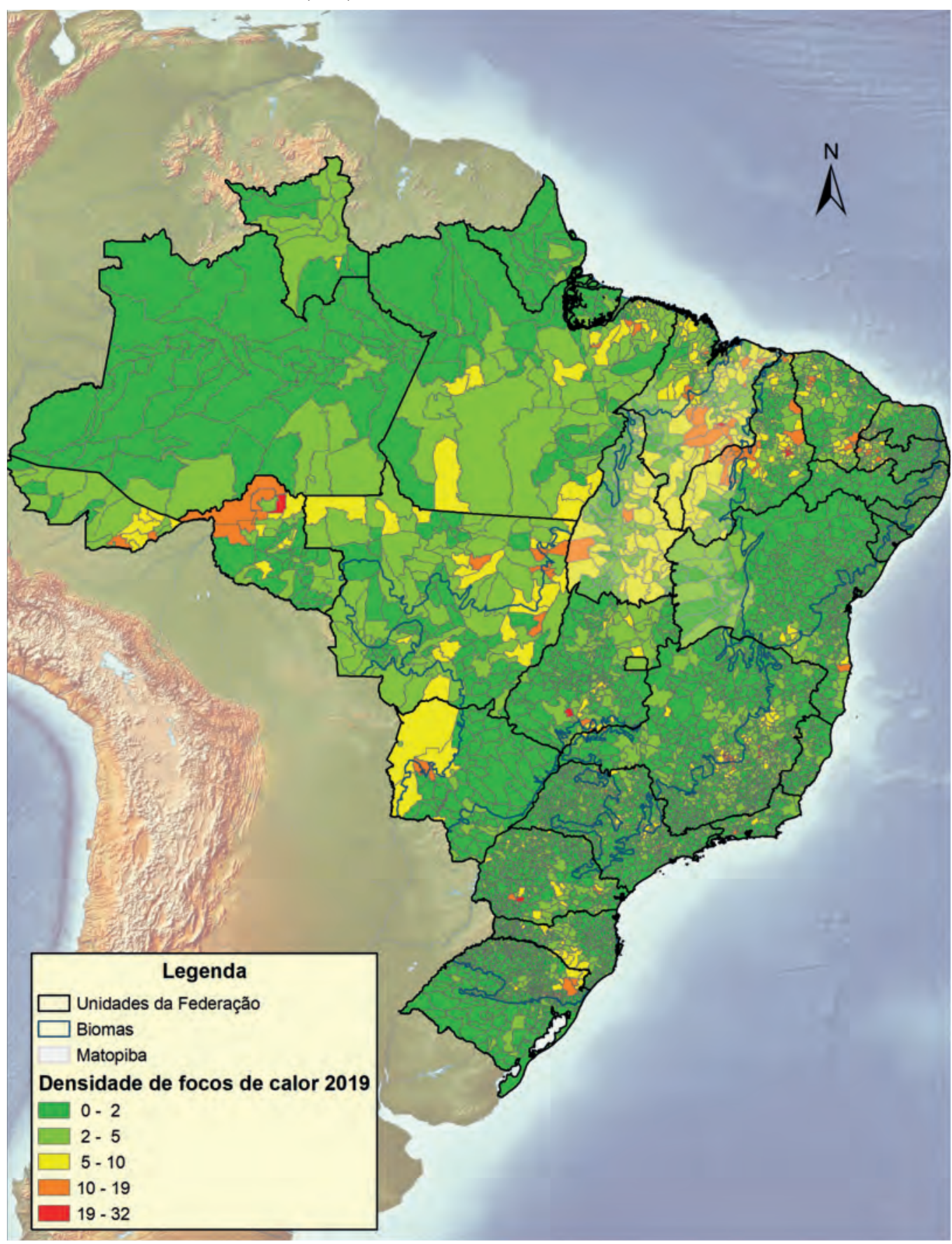


1B - Densidade de focos de calor (2018)

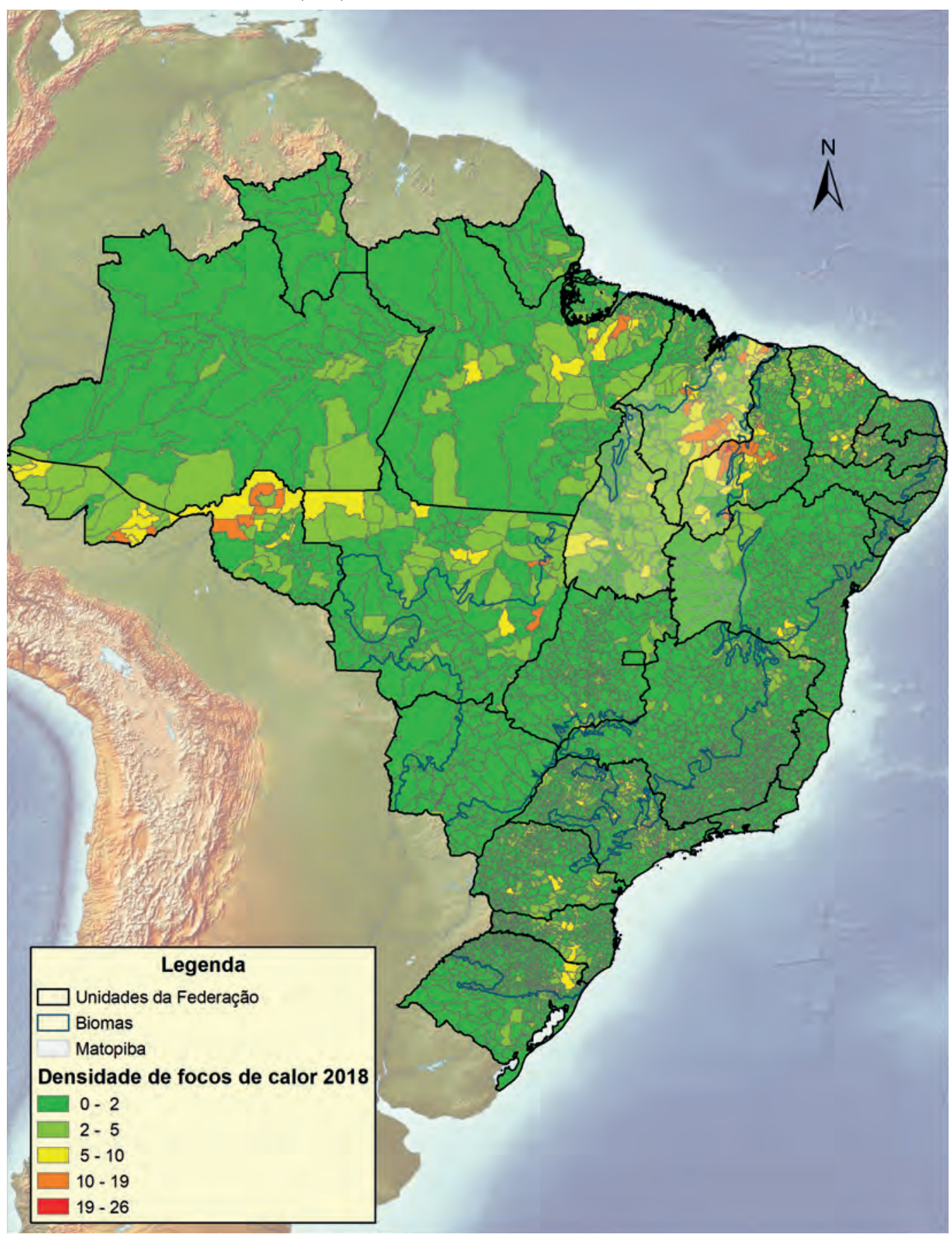


1C - Densidade de focos de calor (2017)

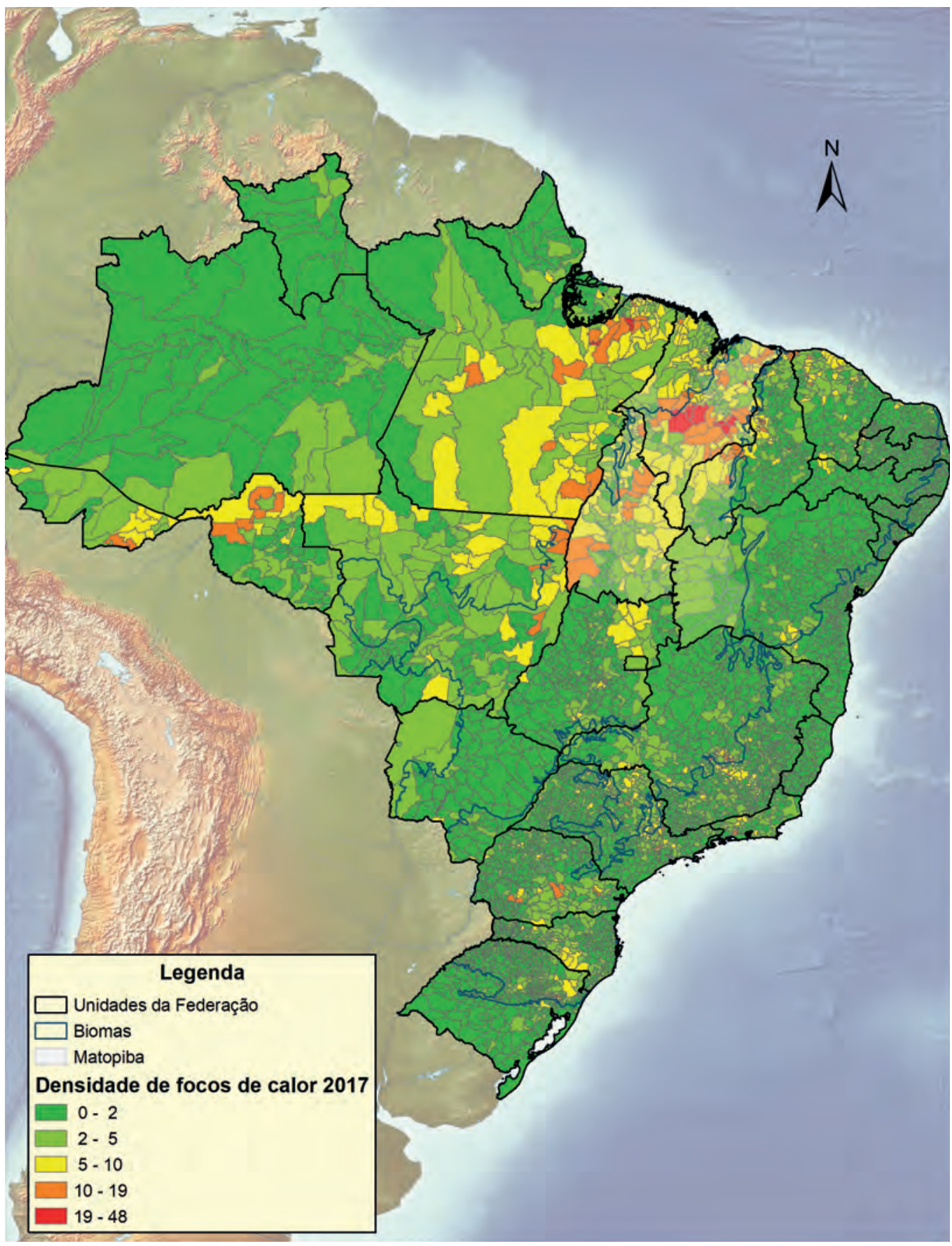


1D - Densidade de focos de calor (2016)

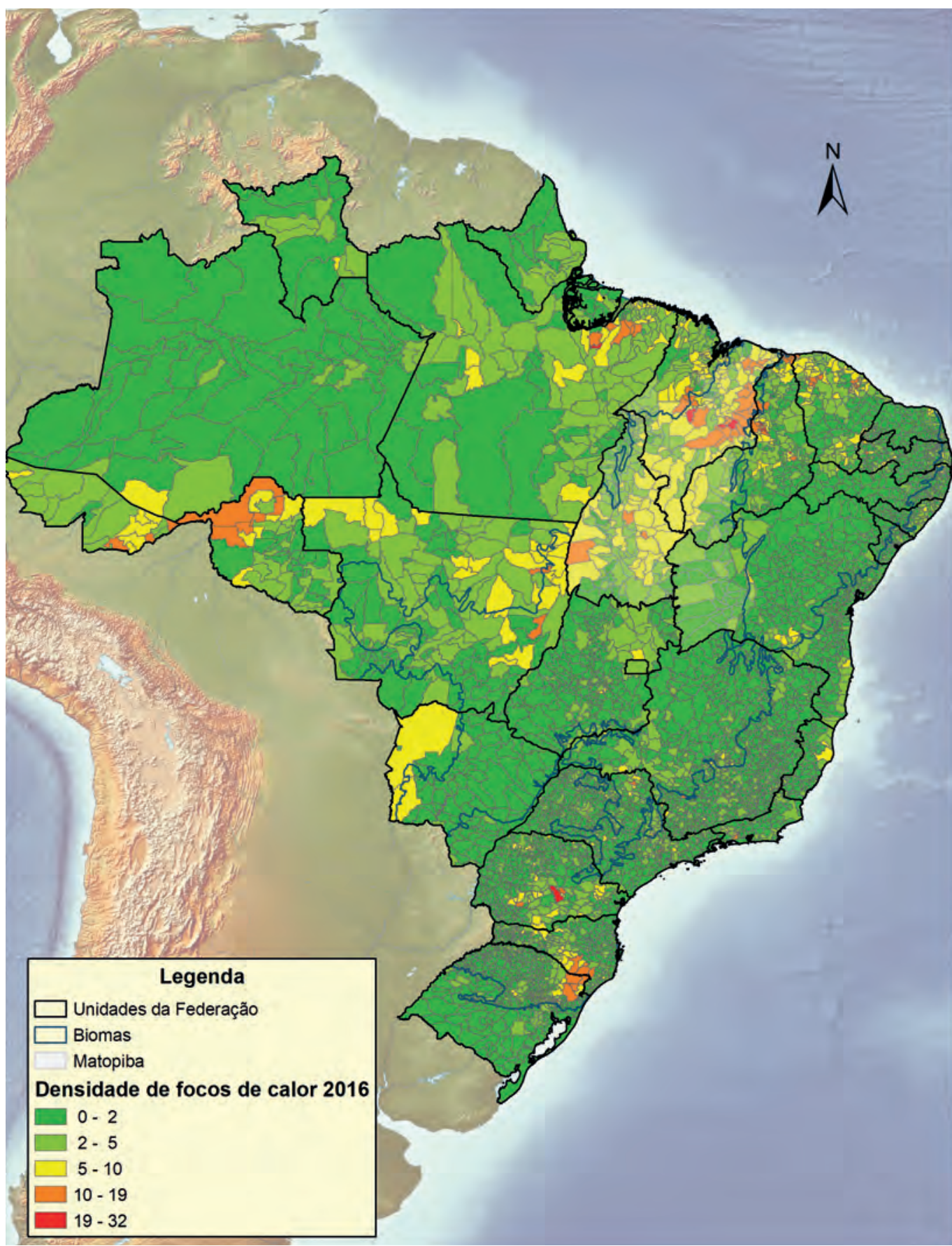


$1 E$ - Densidade de focos de calor (2015)

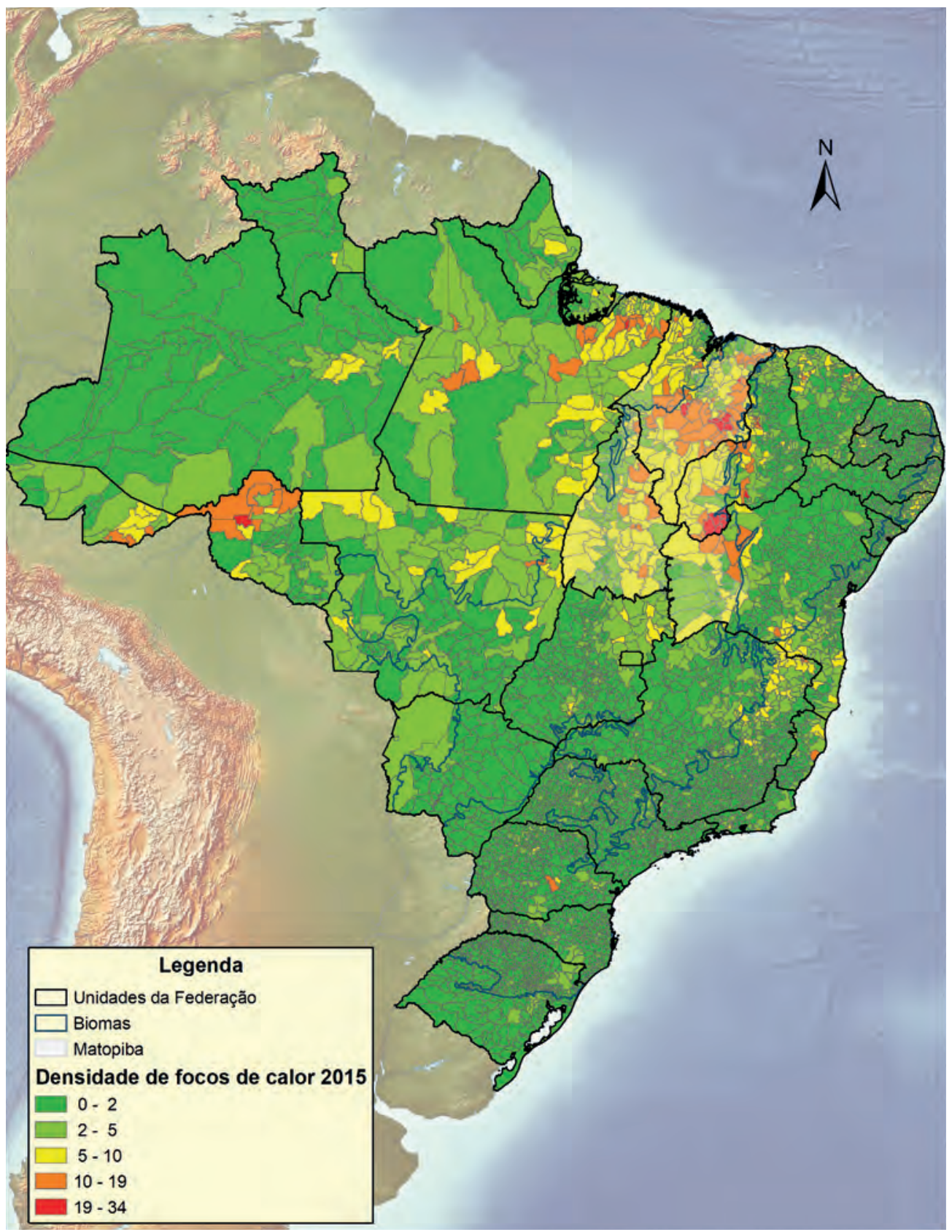


$1 F$ - Densidade de focos de calor (2014)

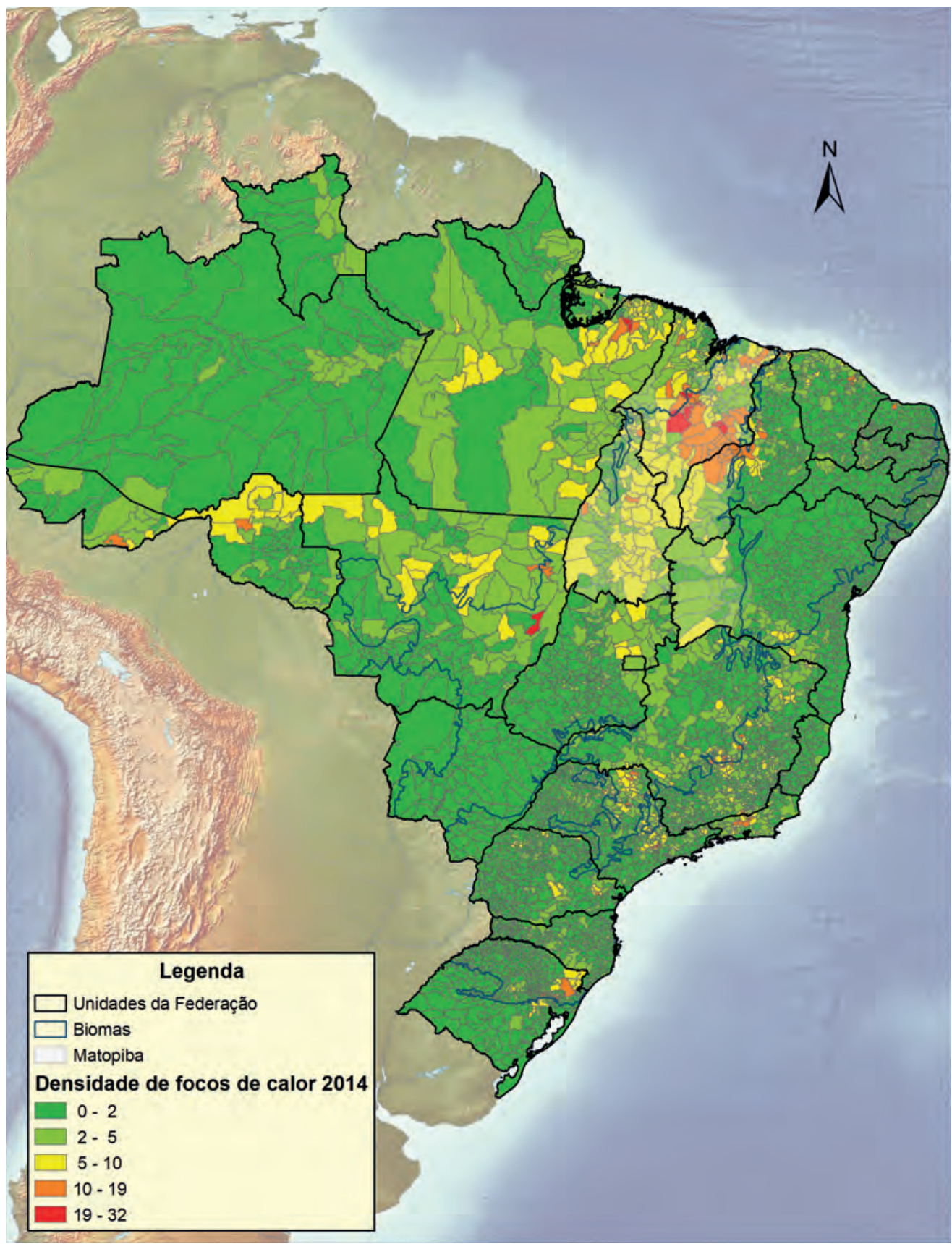


1G - Densidade de focos de calor (2013)

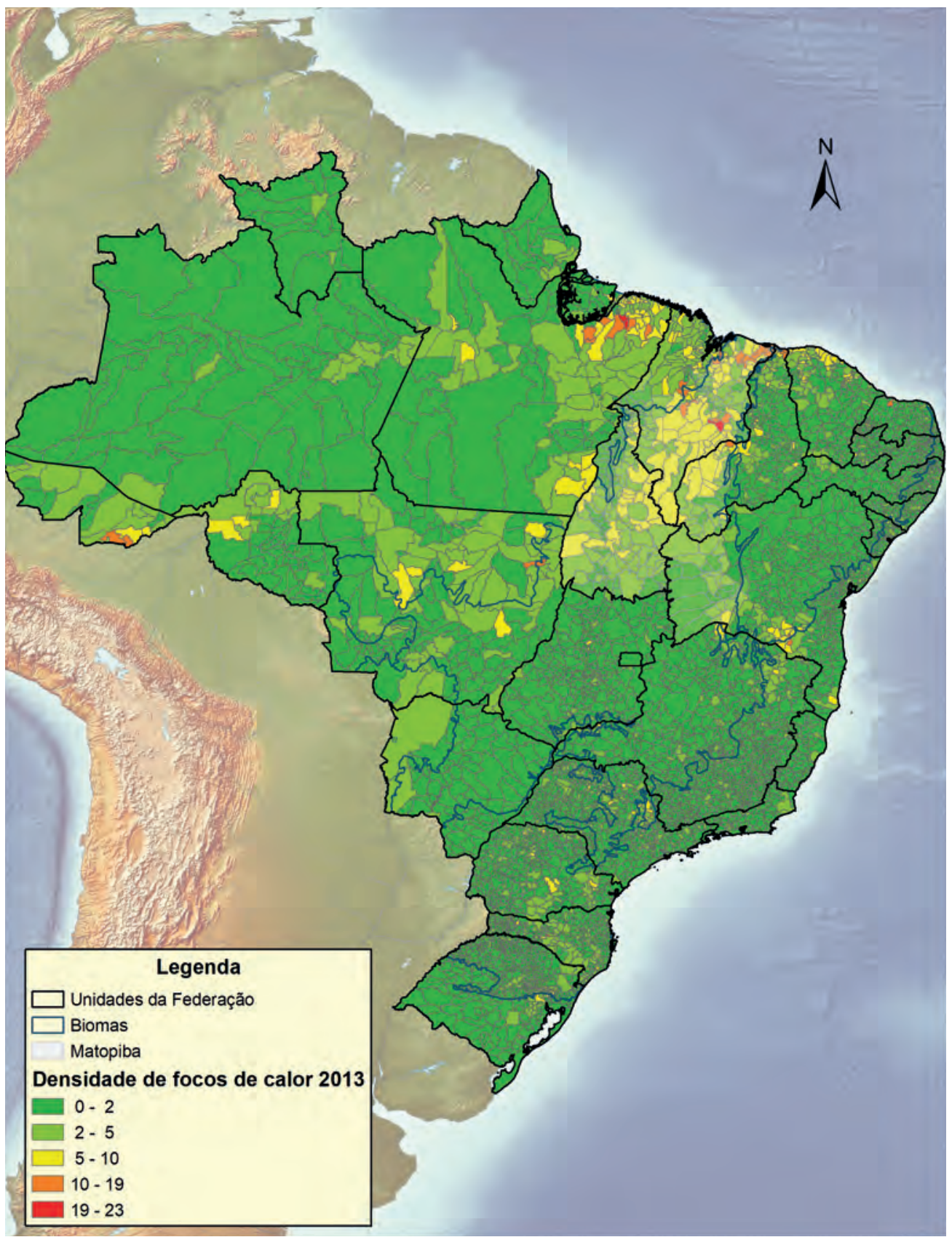


$1 \mathrm{H}$ - Densidade de focos de calor (2012)

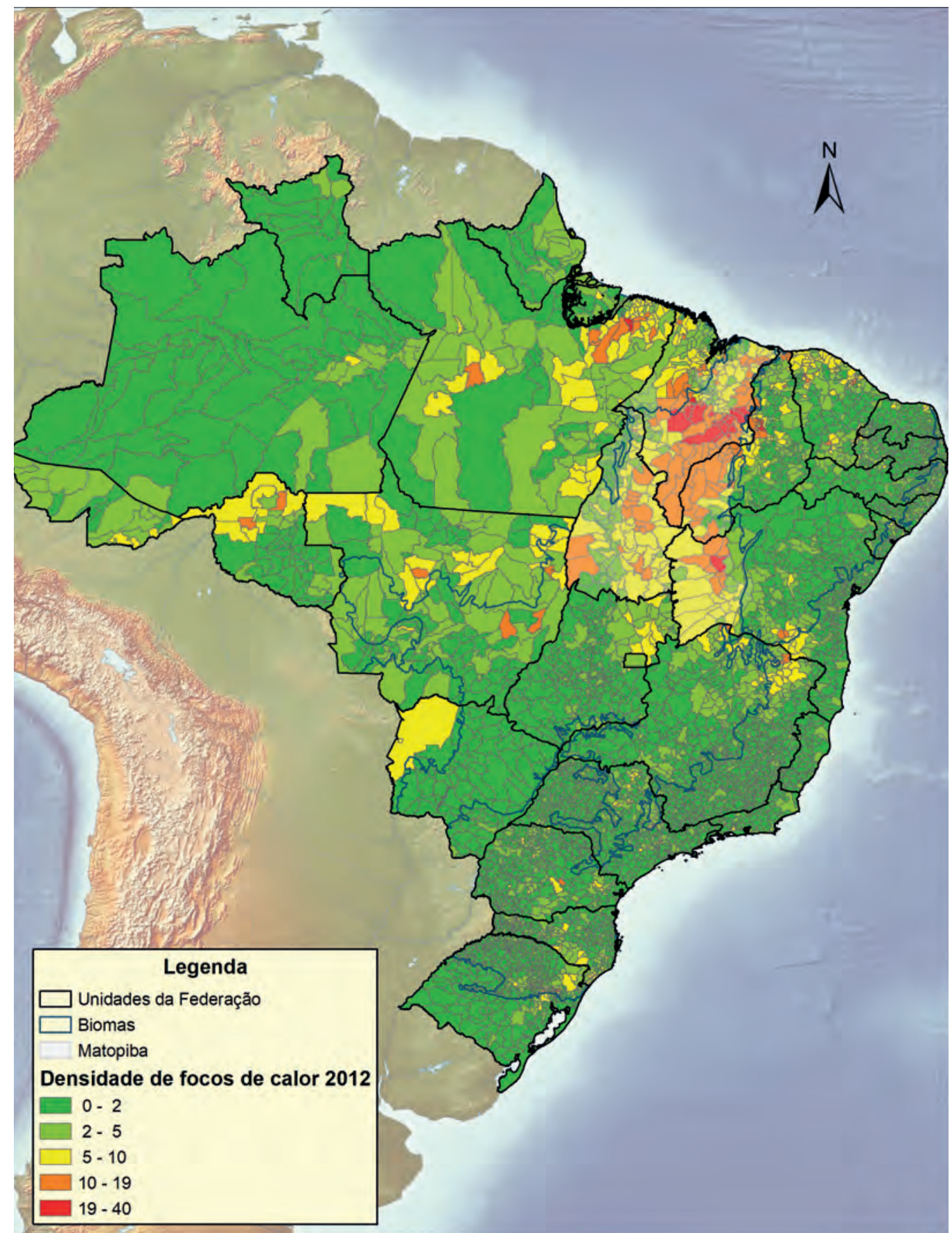

Fonte: Inpe. 



\section{INDICADORES FEDERATIVOS}

\section{INDICADORES FISCAIS DOS ESTADOS DA FEDERAÇÃO NO PERÍODO 2019-2020}

\section{INDICADOR DE ENDIVIDAMENTO}

Representa a parcela da dívida pública consolidada (obrigaçôes financeiras) na receita corrente líquida (RCL) (somatório da arrecadação tributária menos as transferências constitucionais e legais). A tabela 1 apresenta os valores para setembro de 2019 e março e setembro de 2020, assim como a variaçáo entre esses períodos. Entre setembro de 2019 e setembro de 2020, o endividamento estadual caiu em todas as regiōes, à exceção do Sudeste, onde houve um pequeno aumento de $1,4 \%$. Pela ordem, os maiores aumentos relativos foram observados nas dívidas dos estados de Tocantins, Rio Grande do Norte, Pará e Ceará. Os estados com os maiores estoques de dívidas em setembro de 2020 são, por ordem decrescente, Rio de Janeiro, Rio Grande do Sul, Minas Gerais e São Paulo.

TABELA 1

Endividamento: dívida pública consolidada/ $\mathrm{RCL}^{1}$

(Em \%)

\begin{tabular}{|c|c|c|c|c|c|}
\hline & \multirow{2}{*}{$\frac{2019}{\text { Setembro }}$} & \multicolumn{2}{|c|}{2020} & \multirow{2}{*}{$\begin{array}{l}\text { Variação entre setembro } \\
\text { de } 2019 \text { e setembro de } 2020\end{array}$} & \multirow{2}{*}{$\begin{array}{c}\text { Variação entre março e } \\
\text { setembro de } 2020\end{array}$} \\
\hline & & Março & Setembro & & \\
\hline Região Norte & 21,1 & 19,5 & 9,1 & $-56,7$ & $-53,2$ \\
\hline Acre & 53,0 & 60,9 & 50,9 & $-3,8$ & $-16,4$ \\
\hline Amapá & 41,1 & $-44,5$ & $-51,2$ & $-224,6$ & $-15,0$ \\
\hline Amazonas & 34,8 & 33,7 & 22,0 & $-36,8$ & $-34,6$ \\
\hline Pará & 4,7 & 9,0 & 5,8 & 22,2 & $-36,3$ \\
\hline Rondônia & 19,0 & 22,7 & 12,7 & $-33,3$ & $-44,0$ \\
\hline Roraima & $-19,4$ & $-28,5$ & $-69,4$ & $-257,7$ & $-143,5$ \\
\hline Tocantins & 26,7 & 58,3 & 45,2 & 69,2 & $-22,6$ \\
\hline Região Nordeste & 56,5 & 60,8 & 52,4 & $-7,3$ & $-13,8$ \\
\hline Alagoas & 88,2 & 97,6 & 91,6 & 3,9 & $-6,1$ \\
\hline Bahia & 61,1 & 71,9 & 66,2 & 8,3 & $-7,9$ \\
\hline Ceará & 58,8 & 70,7 & 69,3 & 17,8 & $-2,0$ \\
\hline
\end{tabular}

1. DOI: http://dx.doi.org/10.38116/brua24art24 


\begin{tabular}{|c|c|c|c|c|c|}
\hline & \multirow{2}{*}{$\begin{array}{c}2019 \\
\text { Setembro }\end{array}$} & \multicolumn{2}{|c|}{2020} & \multirow{2}{*}{$\begin{array}{l}\text { Variação entre setembro } \\
\text { de } 2019 \text { e setembro de } 2020\end{array}$} & \multirow{2}{*}{$\begin{array}{c}\text { Variação entre março e } \\
\text { setembro de } 2020\end{array}$} \\
\hline & & Março & Setembro & & \\
\hline Maranhão & 51,4 & 38,9 & 17,2 & $-66,5$ & $-55,6$ \\
\hline Paraíba & 29,4 & 26,1 & 14,3 & $-51,4$ & $-45,2$ \\
\hline Pernambuco & 56,7 & 63,8 & 57,5 & 1,4 & $-10,0$ \\
\hline Piauí & 66,4 & 51,7 & 37,4 & $-43,7$ & $-27,7$ \\
\hline Rio Grande do Norte & 18,6 & 41,0 & 24,3 & 30,4 & $-40,8$ \\
\hline Sergipe & 74,9 & 57,9 & 61,9 & $-17,3$ & 6,9 \\
\hline Região Centro-Oeste & 55,9 & 49,3 & 43,6 & $-22,1$ & $-11,7$ \\
\hline Distrito Federal & 32,9 & 30,2 & 34,5 & 5,0 & 14,4 \\
\hline Goiás & 87,8 & 82,8 & 79,9 & $-9,0$ & $-3,5$ \\
\hline Mato Grosso & 32,1 & 21,3 & 9,3 & $-71,1$ & $-56,4$ \\
\hline Mato Grosso do Sul & 69,0 & 58,8 & 42,3 & $-38,8$ & $-28,1$ \\
\hline Região Sudeste & 206,8 & 208,7 & 209,7 & 1,4 & 0,5 \\
\hline Espírito Santo & 13,6 & 11,4 & 9,9 & $-27,0$ & $-12,7$ \\
\hline Minas Gerais & 208,4 & 213,5 & 207,2 & $-0,6$ & $-3,0$ \\
\hline Rio de Janeiro & 291,4 & 309,5 & 322,8 & 10,7 & 4,3 \\
\hline São Paulo & 193,8 & 189,2 & 189,1 & $-2,4$ & $-0,1$ \\
\hline Região Sul & 120,5 & 118,6 & 116,3 & $-3,5$ & $-1,9$ \\
\hline Paraná & 36,9 & 28,0 & 24,2 & $-34,5$ & $-13,8$ \\
\hline Santa Catarina & 68,6 & 66,4 & 56,2 & $-18,1$ & $-15,4$ \\
\hline Rio Grande do Sul & 241,1 & 244,1 & 250,0 & 3,7 & 2,4 \\
\hline Total Brasil' & 128,4 & 127,8 & 122,6 & $-4,5$ & $-4,1$ \\
\hline
\end{tabular}

Fonte: Banco Central do Brasil (BCB).

Notas: ${ }^{1}$ Valores mensais da RCL acumulados em doze meses. Dados da RCL estimados com base nos relatórios de gestão fiscal dos governos estaduais. ${ }^{2}$ Refere-se à soma de todas as regiões.

Obs.: Para as três primeiras colunas numéricas, (-) é a posição credora.

\section{INDICADOR DO SERVIÇO DA DÍVIDA}

Medida da parcela das despesas com juros da dívida em relação à RCL. De maneira geral, comparando as variaçóes ocorridas em doze meses, na penúltima coluna da tabela 2 , o indicador é decrescente nas escalas estadual, regional e nacional (exceto nos estados do Rio Grande do Norte e Rio de Janeiro), refletindo a medida de suspensão do pagamento dos juros das dívidas estaduais junto à Uniáo durante o período da pandemia. Os estados de Roraima, Rondônia e Tocantins apresentaram as maiores quedas no indicador.

TABELA 2

Serviço da dívida: serviço da dívida (juros)/RCL ${ }^{1}$

$(\mathrm{Em} \%)$

\begin{tabular}{|c|c|c|c|c|c|}
\hline & \multirow{2}{*}{$\begin{array}{c}2019 \\
\text { Setembro }\end{array}$} & \multicolumn{2}{|c|}{2020} & \multirow{2}{*}{$\begin{array}{c}\text { Variação entre setembro } \\
\text { de } 2019 \text { e setembro de } 2020\end{array}$} & \multirow{2}{*}{$\begin{array}{l}\text { Variação entre março } \\
\text { e setembro de } 2020\end{array}$} \\
\hline & & Março & Setembro & & \\
\hline Região Norte & 1,4 & 1,1 & 0,7 & $-54,3$ & $-41,3$ \\
\hline Acre & 3,3 & 2,8 & 3,1 & $-4,1$ & 11,2 \\
\hline Amapá & 2,4 & 2,2 & 1,1 & $-55,7$ & $-51,8$ \\
\hline Amazonas & 1,6 & 1,3 & 0,9 & $-42,6$ & $-28,7$ \\
\hline Pará & 0,7 & 0,5 & 0,4 & $-38,2$ & $-22,3$ \\
\hline Rondônia & 1,7 & 1,2 & 0,5 & $-69,0$ & $-58,4$ \\
\hline
\end{tabular}




\begin{tabular}{|c|c|c|c|c|c|}
\hline & \multirow{2}{*}{$\begin{array}{c}2019 \\
\text { Setembro }\end{array}$} & \multicolumn{2}{|c|}{2020} & \multirow{2}{*}{$\begin{array}{l}\text { Variação entre setembro } \\
\text { de } 2019 \text { e setembro de } 2020\end{array}$} & \multirow{2}{*}{$\begin{array}{l}\text { Variação entre março } \\
\text { e setembro de } 2020\end{array}$} \\
\hline & & Março & Setembro & & \\
\hline Roraima & 0,6 & 0,2 & 0,2 & $-70,3$ & $-3,3$ \\
\hline Tocantins & 1,4 & 0,8 & 0,5 & $-63,5$ & $-39,6$ \\
\hline Região Nordeste & 2,6 & 2,3 & 1,9 & $-29,3$ & $-18,8$ \\
\hline Alagoas & 6,2 & 5,6 & 3,9 & $-36,5$ & $-29,1$ \\
\hline Bahia & 2,4 & 2,1 & 2,0 & $-16,2$ & $-1,1$ \\
\hline Ceará & 2,9 & 2,8 & 2,8 & $-6,2$ & $-2,5$ \\
\hline Maranhão & 2,4 & 1,9 & 1,4 & $-43,0$ & $-25,5$ \\
\hline Paraíba & 1,1 & 0,9 & 0,6 & $-44,6$ & $-36,5$ \\
\hline Pernambuco & 3,0 & 2,6 & 1,8 & $-40,9$ & $-32,1$ \\
\hline Piauí & 2,9 & 2,3 & 1,2 & $-57,4$ & $-46,8$ \\
\hline Rio Grande do Norte & 0,7 & 0,8 & 0,9 & 34,4 & 24,3 \\
\hline Sergipe & 2,5 & 2,2 & 1,6 & $-34,0$ & $-25,3$ \\
\hline Região Centro-Oeste & 3,6 & 3,2 & 2,8 & $-22,3$ & $-11,0$ \\
\hline Distrito Federal & 1,1 & 1,0 & 0,7 & $-33,7$ & $-26,5$ \\
\hline Goiás & 6,7 & 6,2 & 6,6 & $-1,0$ & 6,5 \\
\hline Mato Grosso & 2,4 & 1,8 & 1,1 & $-53,1$ & $-38,5$ \\
\hline Mato Grosso do Sul & 4,2 & 3,2 & 2,0 & $-51,5$ & $-36,9$ \\
\hline Região Sudeste & 11,6 & 10,7 & 9,3 & $-19,9$ & $-13,4$ \\
\hline Espírito Santo & 1,5 & 1,4 & 1,2 & $-22,8$ & $-15,2$ \\
\hline Minas Gerais & 12,8 & 12,1 & 10,4 & $-18,7$ & $-14,0$ \\
\hline Rio de Janeiro & 16,9 & 16,5 & 17,9 & 5,8 & 8,0 \\
\hline São Paulo & 10,1 & 8,9 & 6,5 & $-35,6$ & $-27,0$ \\
\hline Região Sul & 5,9 & 5,5 & 4,3 & $-26,1$ & $-20,9$ \\
\hline Paraná & 2,0 & 1,5 & 0,8 & $-58,5$ & $-43,7$ \\
\hline Santa Catarina & 3,3 & 2,8 & 2,0 & $-41,5$ & $-29,4$ \\
\hline Rio Grande do Sul & 11,5 & 11,3 & 9,5 & $-17,7$ & $-16,3$ \\
\hline Total Brasil ${ }^{2}$ & 7,0 & 6,4 & 5,3 & $-24,0$ & $-16,4$ \\
\hline
\end{tabular}

\section{INDICADOR DA PARCELA DO RESULTADO PRIMÁRIO QUE SERVE À DÍVIDA}

Indicador calculado pela razão entre a necessidade de financiamento (despesas não financeiras menos as receitas não financeiras) e a despesa com juros da dívida. Valor positivo (negativo) significa aumento (abatimento) no estoque da dívida. Considerando os sinais dos valores em março e setembro de 2020, o resultado primário se mostrou favorável à redução do endividamento nas regiōes Norte, Nordeste, Centro-Oeste e Sudeste. Apenas na região Sul, em face dos deficit primários observados no Paraná e no Rio Grande do Sul, observou-se a predominância de aumento no estoque das dívidas estaduais. Outros estados que registraram deficit primários no período foram Piauí, Rio Grande do Norte, Sergipe e Minas Gerais. 
TABELA 3

Resultado primário que serve à dívida: necessidade de financiamento/serviço da dívida (juros) ${ }^{1}$ (Em \%)

\begin{tabular}{|c|c|c|c|c|c|}
\hline & \multirow{2}{*}{$\begin{array}{c}2019 \\
\text { Setembro }\end{array}$} & \multicolumn{2}{|c|}{2020} & \multirow{2}{*}{$\begin{array}{l}\text { Variação entre setembro } \\
\text { de } 2019 \text { e setembro de } 2020\end{array}$} & \multirow{2}{*}{$\begin{array}{l}\text { Variação entre março } \\
\text { e setembro de } 2020\end{array}$} \\
\hline & & Março & Setembro & & \\
\hline Região Norte & $-317,6$ & $-322,5$ & $-1.602,5$ & 404,5 & 396,9 \\
\hline Acre & $-202,9$ & $-231,4$ & $-541,9$ & 167,1 & 134,2 \\
\hline Amapá & $-80,2$ & $-120,3$ & $-1.105,3$ & $1.277,8$ & 818,9 \\
\hline Amazonas & $-22,3$ & $-272,1$ & $-1.570,0$ & $6.926,6$ & 477,1 \\
\hline Pará & 252,0 & 341,3 & $-511,1$ & $-302,8$ & $-249,8$ \\
\hline Rondônia & $-537,6$ & $-726,9$ & $-2.174,5$ & 304.5 & 199,2 \\
\hline Roraima & $-3.936,4$ & $-10.744,2$ & $-12.992,7$ & 230,1 & 20,9 \\
\hline Tocantins & $-954,4$ & $-363,8$ & $-2.698,7$ & 182,8 & 641,8 \\
\hline Região Nordeste & 5,7 & $-28,9$ & $-243,3$ & $-4.403,4$ & 741,8 \\
\hline Alagoas & $-67,7$ & $-62,8$ & $-62,7$ & $-7,3$ & $-0,1$ \\
\hline Bahia & 30,6 & 76,8 & $-259,0$ & $-945,1$ & $-437,2$ \\
\hline Ceará & 81,0 & 10,2 & $-62,2$ & $-176,8$ & $-708,3$ \\
\hline Maranhão & 2,2 & $-203,1$ & $-1.129,3$ & $-52.275,3$ & 456,1 \\
\hline Paraíba & $-5,2$ & $-542,3$ & $-2.889,0$ & $55.351,3$ & 432,7 \\
\hline Pernambuco & $-98,3$ & $-46,6$ & $-121,6$ & 23,7 & 160,9 \\
\hline Piauí & $-67,3$ & $-139,9$ & 312,5 & $-564,3$ & $-323,3$ \\
\hline Rio Grande do Norte & 614,1 & 542,6 & $-204,1$ & $-133,2$ & $-137,6$ \\
\hline Sergipe & 141,4 & 4,1 & 257,8 & 82,7 & $6.191,8$ \\
\hline Região Centro-Oeste & 31,8 & $-141,2$ & $-392,8$ & $-1.334,4$ & 178,3 \\
\hline Distrito Federal & 589,8 & $-321,5$ & $-247,5$ & $-142,0$ & $-23,0$ \\
\hline Goiás & 30,9 & 4,1 & $-174,7$ & $-666,0$ & $-4.378,4$ \\
\hline Mato Grosso & $-131,6$ & $-489,1$ & $-1.449,2$ & $1.001,6$ & 196,3 \\
\hline Mato Grosso do Sul & $-132,8$ & $-311,7$ & $-948,0$ & 614,0 & 204,2 \\
\hline Região Sudeste & 4,3 & $-14,6$ & $-57,7$ & $-1.432,2$ & 295,7 \\
\hline Espírito Santo & $-246,4$ & 5,6 & $-108,8$ & $-55,8$ & $-2.058,2$ \\
\hline Minas Gerais & 17,2 & 37,6 & 5,9 & $-66,0$ & $-84,4$ \\
\hline Rio de Janeiro & 44,1 & $-17,5$ & $-42,1$ & $-195,4$ & 140,3 \\
\hline São Paulo & $-23,1$ & $-41,0$ & $-113,7$ & 391,8 & 177,4 \\
\hline Região Sul & $-41,2$ & 20,5 & 25,0 & $-160,6$ & 22,1 \\
\hline Paraná & $-294,4$ & 251,7 & 301,4 & $-202,4$ & 19,8 \\
\hline Santa Catarina & $-168,8$ & $-127,1$ & $-534,6$ & 216,7 & 320,5 \\
\hline Rio Grande do Sul & 29,2 & 17,7 & 86,4 & 195,9 & 388,7 \\
\hline Total Brasil $^{2}$ & $-6,4$ & $-23,4$ & $-101,1$ & $1.486,9$ & 332,7 \\
\hline
\end{tabular}

Fonte: $\mathrm{BCB}$.

Notas: ${ }^{1}$ Valores mensais dos resultados primários e dos juros da dívida acumulados em doze meses. ${ }^{2}$ Refere-se à soma de todas as regiões.

Obs.: Para as três primeiras colunas numéricas, (-) é o superavit.

\section{4 ÍNDICE DE VULNERABILIDADE FISCAL (IVF)}

Índice ponderado dos indicadores de endividamento (peso 5), do serviço da dívida (peso 3) e de resultado primário servindo à dívida (peso 2). Esse índice é uma adaptação resumida da metodologia utilizada pelo Ministério da Fazenda (MF), entre 2012 e 2017, para a análise da capacidade de pagamento e de contrapartida para a concessão de aval e garantia da União a estados, Distrito Federal e municípios. 
Em termos gerais, no período entre setembro de 2019 e setembro de 2020, o IVF apresentou decréscimo nas regióes Norte, Nordeste, Centro-Oeste e Sudeste, e aumento na regiáo Sul. Os estados que tiveram os maiores crescimentos relativos na vulnerabilidade fiscal foram Piauí, Sergipe e Rio Grande do Sul. Os estados com as maiores reduçôes foram Santa Catarina, Amapá e Paraíba. O indicador aponta situação fiscal crítica (dada por IVF > 100) nos estados de Minas Gerais, Rio de Janeiro e Rio Grande do Sul.

\section{TABELA 4}

IVF

\begin{tabular}{|c|c|c|c|c|c|}
\hline & \multirow{2}{*}{$\begin{array}{c}2019 \\
\text { Setembro }\end{array}$} & \multicolumn{2}{|c|}{2020} & \multirow{2}{*}{$\begin{array}{c}\text { Variação entre setembro } \\
\text { de } 2019 \text { e setembro de } 2020\end{array}$} & \multirow{2}{*}{$\begin{array}{l}\text { Variação entre março } \\
\text { e setembro de } 2020\end{array}$} \\
\hline & & Março & Setembro & & \\
\hline Região Norte & $-52,6$ & $-54,4$ & $-315,7$ & 500,7 & 480,2 \\
\hline Acre & $-13,1$ & $-15,0$ & $-82,0$ & 525,0 & 447,7 \\
\hline Amapá & 5,2 & $-45,6$ & $-246,3$ & $-4.811,9$ & 439,7 \\
\hline Amazonas & 13,4 & $-37,2$ & $-302,7$ & $-2.352,5$ & 714,5 \\
\hline Pará & 52,9 & 72,9 & $-99,2$ & $-287,4$ & $-236,1$ \\
\hline Rondônia & $-97,5$ & $-133,7$ & $-428,4$ & 339,4 & 220,5 \\
\hline Roraima & $-796,8$ & $-2.163,0$ & $-2.633,2$ & 230,5 & 21,7 \\
\hline Tocantins & $-177,1$ & $-43,3$ & $-517,0$ & 191,9 & $1.092,8$ \\
\hline Região Nordeste & 30,2 & 25,3 & $-21,9$ & $-172,6$ & $-186,6$ \\
\hline Alagoas & 32,4 & 37,9 & 34,4 & 6,2 & $-9,2$ \\
\hline Bahia & 37,4 & 51,9 & $-18,1$ & $-148,4$ & $-134,8$ \\
\hline Ceará & 46,5 & 38,2 & 23,0 & $-50,5$ & $-39,8$ \\
\hline Maranhão & 26,9 & $-20,6$ & $-216,8$ & $-906,4$ & 951,4 \\
\hline Paraíba & 14,0 & $-95,1$ & $-570,5$ & $-4.175,0$ & 499,7 \\
\hline Pernambuco & 9,6 & 23,4 & 4,9 & $-48,4$ & $-78,9$ \\
\hline Piauí & 20,6 & $-1,4$ & 81,6 & 295,7 & $-5.816,1$ \\
\hline Rio Grande do Norte & 132,3 & 129,2 & $-28,4$ & $-121,5$ & $-122,0$ \\
\hline Sergipe & 66,4 & 30,4 & 83,0 & 25,0 & 172,9 \\
\hline Região Centro-Oeste & 35,4 & $-2,6$ & $-55,9$ & $-257,9$ & $2.027,8$ \\
\hline Distrito Federal & 134,7 & $-48,9$ & $-32,0$ & $-123,8$ & $-34,5$ \\
\hline Goiás & 52,1 & 44,1 & 7,0 & $-86,6$ & $-84,1$ \\
\hline Mato Grosso & $-9,6$ & $-86,6$ & $-284,9$ & $2.874,2$ & 228,8 \\
\hline Mato Grosso do Sul & 9,2 & $-32,0$ & $-167,9$ & $-1.923,2$ & 424,8 \\
\hline Região Sudeste & 107,7 & 104,6 & 96,1 & $-10,8$ & $-8,2$ \\
\hline Espírito Santo & $-42,0$ & 7,2 & $-16,4$ & -60.9 & $-327,5$ \\
\hline Minas Gerais & 111,5 & 117,9 & 107,9 & $-3,2$ & $-8,5$ \\
\hline Rio de Janeiro & 159,6 & 156,2 & 158,3 & $-0,8$ & 1,4 \\
\hline São Paulo & 95,3 & 89,1 & 73,8 & $-22,6$ & $-17,2$ \\
\hline Região Sul & 53,8 & 65,0 & 64,5 & 19,8 & $-0,9$ \\
\hline Paraná & $-39,8$ & 64,8 & 72,6 & $-282,3$ & 12,1 \\
\hline Santa Catarina & 1,6 & 8,6 & $-78,2$ & $-5.080,3$ & $-1.009,9$ \\
\hline Rio Grande do Sul & 129,9 & 129,0 & 145,1 & 11,8 & 12,5 \\
\hline Total Brasil' & 65,0 & 61,1 & 42,7 & $-34,4$ & $-30,2$ \\
\hline
\end{tabular}

Fonte: $\mathrm{BCB}$.

Nota: ${ }^{1}$ Refere-se à soma de todas as regiões.

Obs.: Situação fiscal: IVF $<10=$ ótima; $10<$ IVF $<20=$ muito boa; $20<$ IVF $<40=$ boa; $40<$ IVF $<60=$ neutra; $60<$ IVF $<80=$ fraca; $80<$ IVF $<100=$ muito fraca; IVF $>100=$ crítica. 
Ipea - Instituto de Pesquisa Econômica Aplicada

\section{Assessoria de Imprensa e Comunicação}

\section{EDITORIAL}

\section{Coordenação}

Reginaldo da Silva Domingos

\section{Supervisão}

Carlos Henrique Santos Vianna

\section{Revisão}

Bruna Oliveira Ranquine da Rocha

Carlos Eduardo Gonçalves de Melo

Elaine Oliveira Couto

Lis Silva Hall

Mariana Silva de Lima

Marlon Magno Abreu de Carvalho

Vivian Barros Volotão Santos

Matheus Tojeiro da Silva (estagiário)

Rebeca Raimundo Cardoso dos Santos (estagiária)

\section{Editoração}

Aline Cristine Torres da Silva Martins

Mayana Mendes de Mattos

Mayara Barros da Mota (estagiária)

\section{Capa}

Danielle de Oliveira Ayres

Flaviane Dias de Sant'ana

\section{Projeto Gráfico}

Renato Rodrigues Bueno

The manuscripts in languages other than Portuguese published herein have not been proofread.

\section{Livraria Ipea}

SBS - Quadra 1 - Bloco J - Ed. BNDES, Térreo.

70076-900 - Brasília - DF

Fone: (61) 2026-5336

Correio eletrônico: livraria@ipea.gov.br 



\section{Missão do Ipea}

Aprimorar as políticas públicas essenciais ao desenvolvimento brasileiro por meio da produção e disseminação de conhecimentos e da assessoria ao Estado nas suas decisões estratégicas. 